$$
\text { UNIVERSIDADE DE SÃO PAULO }
$$

FACULDADE DE FILOSOFIA, LETRAS E CIÊNCIAS HUMANAS

DEPARTAMENTO DE ANTROPOLOGIA

PROGRAMA DE PÓS-GRADUAÇÃO EM ANTROPOLOGIA SOCIAL

GIANCARLO MARQUES CARRARO MACHADO

$$
\text { De "carrinho" pela cidade: }
$$

A prática do street skate em São Paulo

São Paulo 


\author{
UNIVERSIDADE DE SÃO PAULO \\ FACULDADE DE FILOSOFIA, LETRAS E CIÊNCIAS HUMANAS \\ DEPARTAMENTO DE ANTROPOLOGIA \\ PROGRAMA DE PÓS-GRADUAÇÃO EM ANTROPOLOGIA SOCIAL
}

\title{
De "carrinho" pela cidade: \\ A prática do street skate em São Paulo
}

Giancarlo Marques Carraro Machado

Dissertação apresentada ao Programa de Pós-

Graduação em Antropologia Social do Departamento de Antropologia da Faculdade de Filosofia, Letras e Ciências Humanas da Universidade de São Paulo, para obtenção do título de Mestre em Antropologia Social.

Orientador: Prof. Dr. Heitor Frúgoli Jr.

São Paulo

2011 


\section{Giancarlo Marques Carraro Machado}

De "carrinho" pela cidade: a prática do street skate em São Paulo

Dissertação apresentada ao Programa de Pós-

Graduação em Antropologia Social do

Departamento de Antropologia da Faculdade de

Filosofia, Letras e Ciências Humanas da

Universidade de São Paulo, para obtenção do título de Mestre em Antropologia Social.

Orientador: Prof. Dr. Heitor Frúgoli Jr.

Aprovado em:

\section{Banca examinadora}

Prof. Dr.

Instituição:

Assinatura:

$\operatorname{Prof}^{\mathrm{a}} . \mathrm{Dr}^{\mathrm{a}}$

Instituição:

Assinatura:

Prof. Dr.

Instituição:

Assinatura: 


\section{Resumo}

A pesquisa parte da análise dos múltiplos sentidos atribuídos à prática da modalidade street skate em São Paulo. Por meio da etnografia pretende-se evidenciar não só aspectos em torno do exercício de uma prática esportiva, mas, sobretudo, as implicações em virtude dos usos e apropriações dos espaços urbanos por parte dos citadinos. De uma forma bem ampla, vislumbra-se mostrar como a cidade pode ser lida e ordenada simbolicamente por meio de um olhar skatista. A partir do trabalho de campo realizado pretendeu-se descrever, analisar e acompanhar até onde fosse possível o que perpassou as redes criadas através de um evento chamado Circuito Sampa Skate. Nesse sentido, ao pesquisar os diversos lugares skatáveis da cidade e seus respectivos picos, a referência etnográfica não é um único espaço ou aglutinações de pessoas, mas sim, uma multiplicidade de espaços e de atores que se encontram articulados por meio de redes mais amplas de relações. Desse modo, tem-se a chance de relacionar os distintos recortes inseridos no universo do street skate em São Paulo, sendo esse não definido $a$ priori, mas construído a partir de discursos, práticas e representações heterogêneas, e em meio a uma dinâmica relacional que se manifesta situacionalmente.

Palavras-chave: skate; espaços urbanos; redes de relações; sociabilidade urbana; citadinidade. 


\begin{abstract}
This study part of the analysis of the multiple meanings attributed to the practice of street skateboarding in São Paulo. Through ethnography aims to highlight not only issues surrounding the practice of a sport, but mainly the implications of the uses and appropriations of urban space; and how the city can be read symbolically and ordered through a olhar skatista. From the fieldwork was intended to describe, analyze and follow as far as possible what was passed overt the networks created through an event called Circuito Sampa Skate. In this sense, to research the various lugares skatáveis of the city and their respective picos, the reference is not an ethnographic single space or clumps of people, but rather a multiplicity of spaces and actor that are articulated through wider networks of relations. Thus, there is a chance to relate the different cuttings of the universe of street skateboarding in São Paulo, this is not defined a priori, but constructed out of discourses, practices and representations heterogeneous, and in the middle of a dynamic relational manifested situationally.
\end{abstract}

Key words: skateboarding; urban spaces; networks, urban sociability, cities. 
Para Nayara, com todo carinho. 


\section{AGRADECIMENTOS}

Agradeço ao CNPq pela bolsa concedida nos primeiros meses de mestrado e, principalmente, à FAPESP, por financiar a pesquisa em boa parte de seu tempo restante.

Ao Prof. Dr. Heitor Frúgoli Jr. pela orientação, incentivo e confiança depositada em meu trabalho. Sou muitíssimo grato a todo o seu apoio, o qual foi de suma importância não só para a realização desta dissertação, mas para o meu amadurecimento como pesquisador.

Ao Prof. Dr. Luiz Henrique de Toledo e a Prof ${ }^{a}$. Dr ${ }^{\mathrm{a}}$. Rose Satiko Gitirana Hikiji por aceitarem participar da qualificação e da defesa desta presente pesquisa. Os comentários, sugestões e apontamentos feitos foram extremamente valiosos para a condução do trabalho. Obrigado!

Aos professores do PPGAS/USP que, direta ou indiretamente, contribuíram para o andamento desta pesquisa e para a minha formação.

Aos funcionários do Departamento de Antropologia.

Aos colegas do Grupo de Estudo de Antropologia da Cidade (GEAC), pela boa convivência e troca de experiências a cada reunião. Agradeço aos participantes e exparticipantes, dentre eles: Bianca Barbosa Chizzolini, Bruno Puccinelli, Carlos Roberto F. de Aquino, Enrico Spaggiari, Guilherme Aderaldo, Inácio de Carvalho D. de Andrade, Isadora Zuza da Fonseca, Juliana Blasi Cunha, Júlio César Talhari, Karina Fasson, Marina Rebeca Saraiva, Mayã Martins, Natália Helou Fazzioni, Weslei Estradiote Rodrigues.

Aos colegas do PPGAS/USP com os quais compartilhei bons momentos dessa aventura acadêmica, em especial Rosenilton Oliveira, Carlos Gutierrez, Samantha Gaspar, Bruna Angotti, Andrea Cavalheiro e Janaína Gomes. 
As boas amizades construídas ao longo do mestrado. Agradeço a Enrico Spaggiari, meu camarada fanático por futebol, cujas idéias e conversas sempre despertaram novas perspectivas em minha pesquisa. E também agradeço a Guilhermo Aderaldo pelo companheirismo e por compartilhar muitos momentos motivantes, os quais sempre me deram ânimo para seguir em frente.

A todos os professores da Universidade Estadual de Montes Claros (Unimontes - MG), em especial, ao Prof. Dr. João Batista de Almeida Costa, a quem sou muito grato por me apresentar a Antropologia e por me incentivar a trilhar os caminhos na mesma.

Ao amigo e historiador Leonardo Brandão, por compartilhar comigo muitas idéias tendo em vista o nosso interesse em comum, ou seja, o universo do skate.

Ao amigo Renato Aquino Neri, que saiu lá das Gerais para demonstrar ser um grande companheiro aqui nesta metrópole.

A todas as pessoas com as quais tive contato no universo do street skate paulistano, dentre elas: Alexandre "Cotinz", Alexandre "Nicolau", Alexandre Vianna, André "Hiena”, André Manto, Arthur Soares, Caio Youssef, Charles Franco, Daniel Santi, Douglas Prieto, Everton Canuto, Everton "Maninho", Fabio Brandão, Felipe Nery, Fernanda Valiati, "Guil” Martins, "Guega" Cervone, Igor Smith, Jennifer Santos, Jorge Costa, Juan Aliste, Lucas "Xaparral”, Mariana Nunes, Marcelo "Dohdoh", Marcelo Viegas, Marcio Tanabe, Mônica Torres, Renan Hassan, Rogerio “Tilskater”, Sandro Sobral, Sandro "Testinha”, Sidney Arakaki, Tiago Garcia, Tiago Lobo, Uriel "Punk", Victor Ferrari, e principalmente a Rodrigo "Bocão" e Raphael "Pezão".

Ao staff da revista Tribo Skate: Caetano Oliveira, Cecília "Mãe”, Cesar Gyrão, Fabio Bolota, Fellipe Francisco, Felipe Minozzi, Heverton Ribeiro, Marcelo "Mug", Otavio Neto e Shin Shikuma.

Ao amigo Marcio Makoto pela boa convivência e pelas risadas ao final de cada dia em São Paulo. 
Aos meus tios e tias da família Carraro: Margarida, Santa, Madalena, Maria Helena, Joel, Jaime e Júlio.

Aos meus tios e tias da família Machado: Zezé, Isabel, Marina, Antônio, Sebastião e Móises.

A todos os meus primos e primas, em especial ao Alisson, por ser minha referência, a Aline pela motivação e a Ana Paula pela serenidade.

A Olívia e José, meus avós, pelo constante exemplo de sabedoria, humildade e confiança na vida.

As minhas irmãs Giovana e Gisele, em quem eu me espelho, por sempre alegrar minha vida em todos os momentos.

A Nayara Alvim, por sempre estar comigo em qualquer circunstância, desde as mais difíceis até as mais alegres. Sem você eu não teria conquistado nada disso. Muito obrigado por tudo. Te amo muito!

A Maria Luiza, minha querida sogra, por ser uma pessoa maravilhosa. E também ao meu cunhado Vinicius e sua companheira Poliana, por toda a amizade.

Dedico esta conquista aos meus amados pais, Márcia e Pedro, que sempre me apoiaram, incentivaram e confiaram verdadeiramente em meu potencial. Vocês são os melhores pais do mundo. Amo vocês!

E por fim, ao Sagrado Coração de Jesus e a Imaculado Coração de Maria. 


\section{SUMÁRIO}

Introdução 14

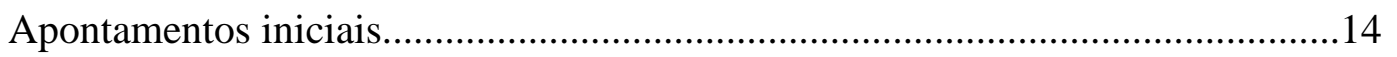

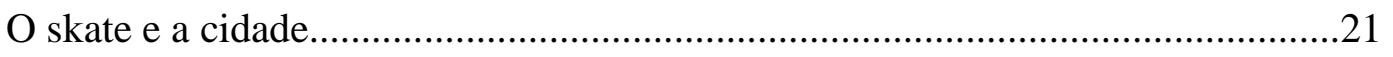

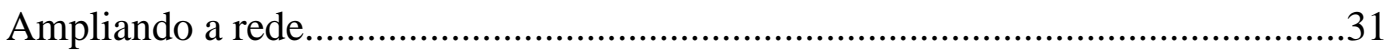

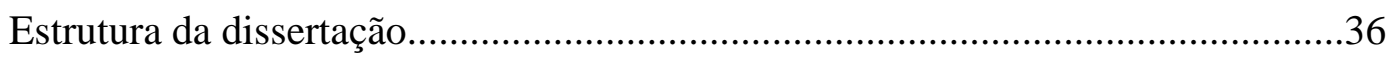

\section{Capítulo I - Circuito Sampa Skate: o importante é (não) competir.....38}

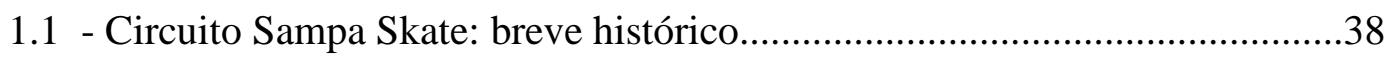

1.2 - Abrindo o circuito: entre skatistas e políticos.............................................41

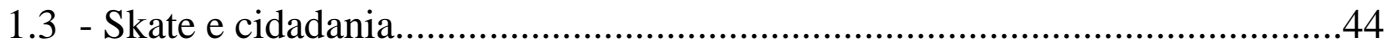

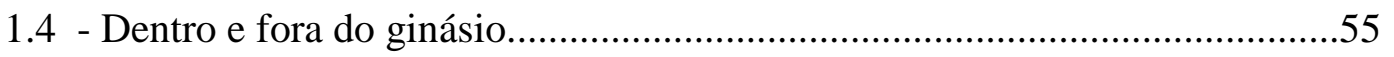

1.5 - Um olhar para a arquibancada..............................................................60

1.5.1 - Preferência musical.......................................................................................60

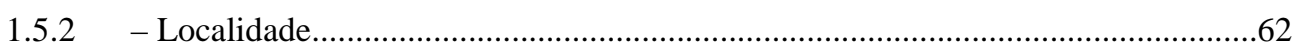

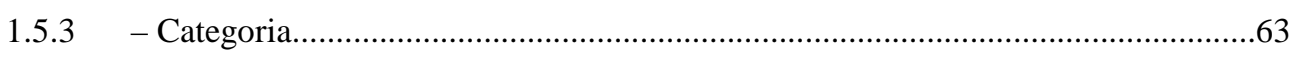

1.5.4 - Dinâmica relacional e situacional..................................................................64

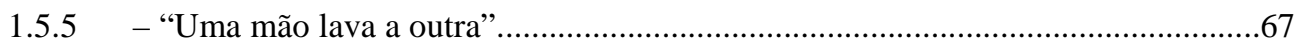

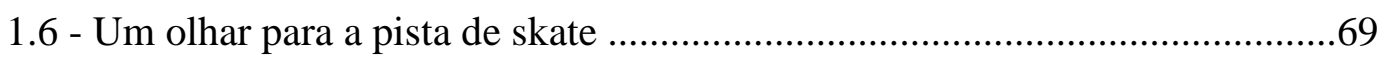

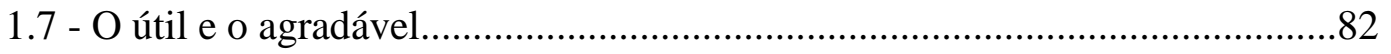

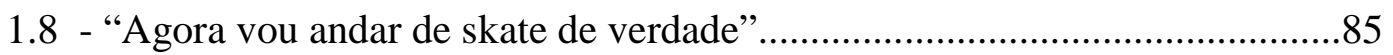

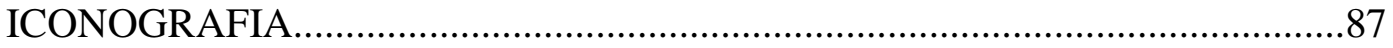

Capítulo II - Entre as pistas e as ruas: em busca de lugares skatáveis.93

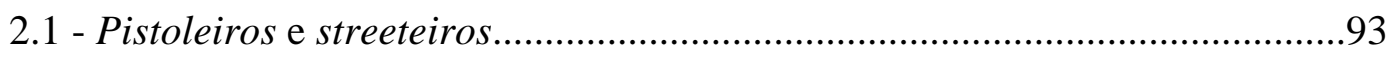

2.2 - Pistas de skate: uma alternativa para os skatistas?......................................99

2.2.1 - Parque Zilda Natel...........................................................................................103

2.2.2 - Skate à luz de velas..........................................................................................106 
2.3 - A cidade vista através do olhar skatista.....................................................113

2.4 - Quando os “carrinhos” vão ao Centro..........................................................118

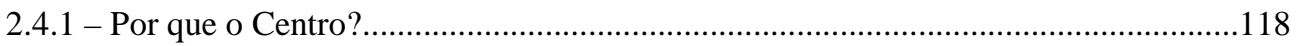

2.4.2 - "Rolê" no Vale do Anhangabaú................................................................................125

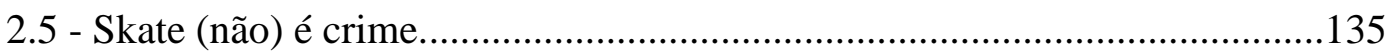

2.5.1 - Skate embaixo da marquise................................................................................138

2.5.2 - "Rolê" no Parque do Ibirapuera..................................................................................144

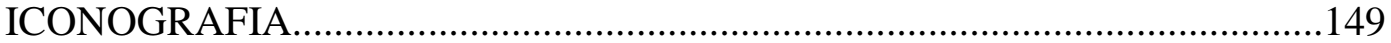

Capítulo III - Skate na cidade, imagens da cidade................................155

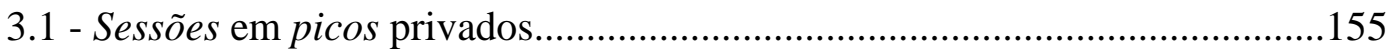

3.1.1 - Estratégias para sessões em picos proibidos............................................................157

3.1.2 - Discursos sobre repressões e permissões..................................................................166

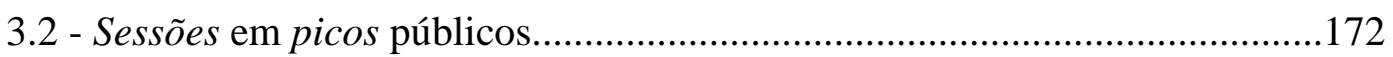

3.3 - Imagens em picos privados e públicos....................................................176

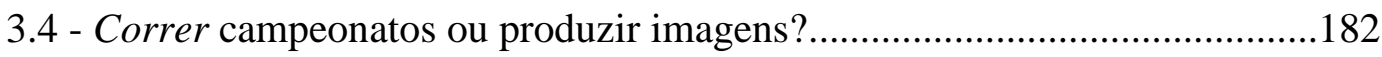

3.4.1 - Competição nas ruas.............................................................................................188

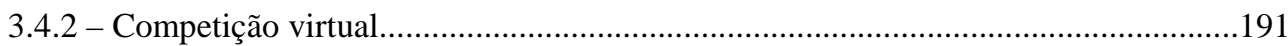

3.5 - Skatistas, fotógrafos e videomakers.........................................................193

3.6 - O olhar skatista expresso em revistas e vídeos..........................................205

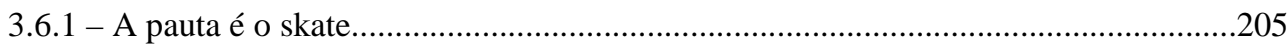

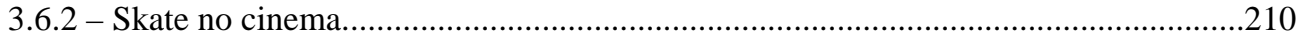

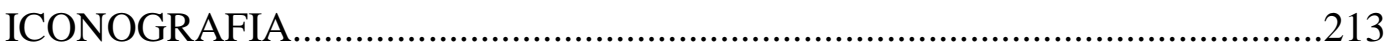

Considerações finais.............................................................................218

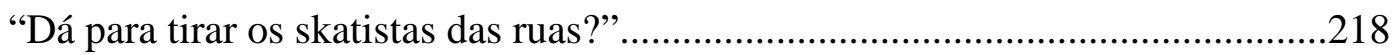

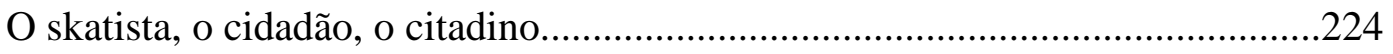

Referências bibliográficas...........................................................................230

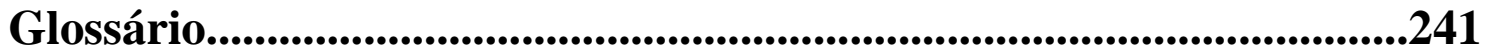


Anexo A - Mega rampa: o espetáculo do skate.................................................246

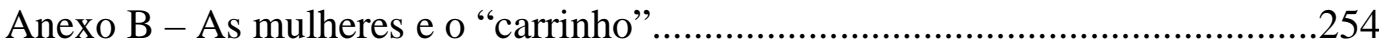

Anexo C - Portfólio para captação de patrocínios................................................262

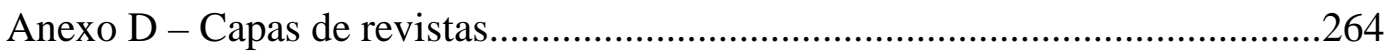

Anexo E - Documentos referentes ao projeto de lei 116/2009..........................265

Anexo F - "Essas ruas são nossas!".................................................................268 
A gente vê a cidade como uma pista de skate gigante. O grande lance é que a cidade está sempre em reforma, sempre em mutação, e a nossa pista está sempre com obstáculos novos para a gente brincar um pouquinho mais (Marcelo "Mug”, 2011). 


\section{Introdução}

\section{Apontamentos iniciais}

O skate pode ser considerado uma das práticas esportivas que mais adquiriu visibilidade nos últimos tempos. Para comprovar esse fato, basta dar uma volta pelas cidades (principalmente as de maior porte). Por meio de um olhar atento é possível encontrar crianças, jovens ou adultos portando seus respectivos “carrinhos" ${ }^{1}$. Devido à proliferação da prática, portanto, o modo muitas vezes apressado e inusitado com que os praticantes circulam pelas ruas e calçadas e utilizam de certos equipamentos urbanos já não causa tanto estranhamento aos demais citadinos.

Mas para que o skate chegasse ao patamar em que se encontra, uma série de mudanças teve que ser realizada, com ressignificações dessa prática. Até meados da década de 50 do século passado, isso não passava de uma mera brincadeira ${ }^{2}$, um entretenimento em que não havia tantos objetivos, como os de realizar manobras, vencer obstáculos, disputar competições ou muito menos de viver profissionalmente do mesmo. Nessa época, a fabricação do objeto o qual entendemos atualmente como "skate" era totalmente improvisada. Na maioria das vezes era feito por meio de rodas de patins soltas e anexadas a uma tábua reta de qualquer madeira. Sendo assim, não havia demasiada preocupação quanto ao formato, durabilidade ou estabilidade.

Somente a partir de 1960 que esse brinquedo improvisado adquiriu novos significados. Com a irregularidade das ondas em praias californianas, vários surfistas norte-americanos apropriaram-se das tábuas com rodinhas e deram um outro sentido ao seu uso: após alterarem seus formatos, ficando semelhantes a uma pequena prancha, elas se tornaram uma espécie de surfe sobre rodas. Através das mesmas os surfistas podiam, de certo modo, surfar a qualquer momento e em muitos lugares, transpondo alguns dos movimentos antes feitos dentro d'água para diversos equipamentos urbanos. Por conta dessa proximidade com o universo do surfe, a prática do skate inicialmente foi chamada de sidewalk surfing, expressão que pode ser traduzida como "surfe de calçada" ${ }^{3}$.

\footnotetext{
1 "Carrinho" é um dos termos usados pelos skatistas para se referir ao skate.

${ }^{2}$ O skate, de acordo com o documentário "Dogtown and Z-Boys: onde tudo começou", lançado em 2001, em seu começo foi associado a uma brincadeira da moda, tal como o ioiô ou o bambolê.

3 Brandão (2009), ao analisar a história da prática do skate a partir do documentário "Dogtown and ZBoys: onde tudo começou" (2001), revela que "a fruição entre o surfe e o skate ou a apropriação dos
} 
Do mar para as ruas. A partir do novo sentido atribuído à prática, o skate, que antes era feito de forma improvisada, passou a ser fabricado e vendido em larga escala. Foi um verdadeiro boom a sua utilização, que atraía cada vez mais a atenção de jovens que estavam à procura de uma atividade inovadora. Embora tenha passado por momentos de maior ou menor visibilidade ao longo do tempo ${ }^{4}$, o skate teve seu universo construído com códigos, símbolos e experiências próprias. Em virtude disso, paulatinamente consolidou-se a atuação de muitos agentes ligados à prática, os quais passaram a investir e atuar na mídia especializada, na organização de eventos, na criação de confederações, na fabricação de produtos, etc. Com efeito, aos poucos foram delineadas distintas funções em meio à dinâmica responsável por transformar aquilo que antes era apenas uma brincadeira em um esporte ${ }^{5}$.

Devido à sua crescente espetacularização em tempos recentes, o skate é muitas vezes tratado como um tipo de atividade atrativa onde se vivenciam diversos tipos de sensações com o corpo e com a mente (como a "liberdade" e a "adrenalina") ${ }^{6}$, associadas ao risco e ao perigo decorrentes de sua realização ${ }^{7}$. Enquanto muitas práticas esportivas valorizam o ideal da força, o skate, ao contrário, se associa sobretudo ao prazer $^{8}$ - ou ao fun, como diria Le Breton $(2009,90)-$, induzindo os corpos dos praticantes à leveza, flexibilidade e plasticidade, expressas por meio das manobras e gestos feitos ${ }^{9}$. Não obstante, por possuir muitas modalidades e por não ser formatada

movimentos do surfe na arte de andar de skate trouxe mudanças significativas para esta atividade. (...) De acordo com o vídeo-documentário analisado, foi justamente no quesito 'estilo' que o surfe revolucionou o skate, e é por terem sido surfistas antes de terem sido skatistas que os 'Z-Boys' conferem a eles próprios o título de 'revolucionários' do skate. (...) Foi a conjugação de dois fatores que provocou o aumento no número de skatistas: a tecnologia (caracterizada principalmente pela introdução do poliuretano às rodas do skate) e a apropriação dos movimentos do surfe em sua prática" (Brandão, 2009, 6).

4 Não é meu objetivo, nesta pesquisa, fazer uma análise histórica do skate. Para uma discussão mais detalhada, vide Brooke (1999) e Brandão (2009).

5 Sobre alguns aspectos do processo de esportivização do skate no Brasil, ver Brandão (2008).

6 Termos como "adrenalina", "radicalidade", "liberdade", entre outros, são constantemente usados pela mídia - principalmente a não especializada - para se referir a certas práticas esportivas, como o skate.

7 A noção de "risco" no skate, como se verá ao longo desta pesquisa, é algo passível de relativização. Para uma análise mais aprofundada sobre a profusão de significados do "risco" em relação às práticas esportivas "radicais", vide Le Breton (2009).

8 O termo "prazer" é recorrente no discurso entre os skatistas, o qual se manifesta por meio de suas práticas que são vistas ora como "diversão", ora como "trabalho", conforme se verá nesta dissertação.

9 A historiadora Denise Sant'Anna (2000, 3), ao analisar certas práticas esportivas tidas como "radicais" - ou esportes californianos, na visão dessa autora - aponta que à medida que elas "se expandem em várias partes do mundo a partir dos anos 70, têm por objetivo menos o cansaço salutar (...) do que a vivência de sensações de prazer, físicas e mentais, imediatas e inovadoras”. Nesse sentido, o skate pode conduzir "o olhar do esportista menos em direção à força realizada por seus músculos do que às flexibilidades motoras que ele é capaz de manter sob controle". 
por tantas regras rígidas ${ }^{10}$, a prática do skate se distingue dos tradicionais esportes coletivos - os quais geralmente são relacionados à disciplina, treinamentos exaustivos, demasiada preparação técnica e tática, disputas agonísticas, etc. ${ }^{11}$ - por ser feita de distintas maneiras e em locais não definidos a priori $^{12}$.

A mídia contribuiu e continua contribuindo para popularizar e dar visibilidade ao skate a partir da divulgação e da promoção de vários eventos, em especial, campeonatos. Dentre muitos exemplos, é válido destacar a realização dos X Games ${ }^{13}$, tradicional competição promovida pelo canal ESPN, desde 1995, com foco nos esportes classificados como "radicais", e também o Maloof Money Cup ${ }^{14}$, competição que distribuiu, em 2011, a quantia de US\$2 milhões aos melhores skatistas colocados. Em função do espetáculo proporcionado por essas e outras competições, os eventos contam com o apoio de inúmeros patrocinadores dos mais diversos segmentos - marcas de bebidas, roupas, calçados, automóveis, alimentos, etc. - que investem consideráveis quantias em um tipo de ação voltada a um público considerado jovem, obtendo, assim, não só lucros exorbitantes, como também a promoção de seus produtos. O skate, portanto, passou a ser visto com bons olhos por muitas empresas, que estrategicamente associam suas marcas a essa prática tendo em vista seus distintos interesses ${ }^{15}$.

Além disso, vários canais de televisão reservam espaços em suas programações para abordar aspectos em torno dos distintos universos relacionados aos esportes "radicais", onde o skate não raro se destaca perante os demais. Isso pode ser

10 Embora existam agências que tentam construir regras e normas em torno da prática do skate (como a Confederação Brasileira de Skate), muitas vezes as mesmas não são seguidas à risca e não são tidas como legítimas. No Capítulo I e Capítulo III serão discutidas certas formas pelas quais os skatistas se relacionam com alguns tipos de regras, voltadas à formatação do skate enquanto uma prática esportiva.

11 Christian Pociello (1995) vislumbra que certas práticas esportivas "radicais" - como o skate, surfe, snowboard, etc. - não só são experimentadas de forma bem distinta dos tradicionais esportes coletivos como também produzem um deslocamento simbólico e até mesmo conceitual no que se convencionou socialmente a se classificar como "esporte".

12 Em sua coluna na Revista CemporcentoSkate (edição 159, 2011), Douglas Prieto afirma que algumas das palavras "malditas" no universo do skate são "atleta"; "campeão" e "treinar". A repulsa a esses termos, de certa forma, relativiza os significados daquilo que se considera como "esporte". Ao longo desta pesquisa demonstrarei etnograficamente novas implicações em relação a essas palavras e ao skate enquanto prática esportiva.

13 O X Games é um evento anual promovido pelo canal de televisão ESPN. Devido ao espetáculo proporcionado, o mesmo é tido como uma "olimpíada dos esportes radicais". Vários países já sediaram edições dos X Games, como Brasil, China e principalmente Estados Unidos. Mais informações: http://espn.estadao.com.br/xgames.

14 O Maloof Money Cup, realizado nos Estados Unidos, é o evento responsável por distribuir a maior premiação em dinheiro já vista na história do skate. Mais informações: http://www.maloofskateboarding.com.

${ }^{15}$ Para mais informações sobre a prática espetacularizada do skate, vide Anexo A. 
comprovado, entre tantos casos, através da novela Malhação ${ }^{16}$, da Rede Globo, que no ano de 2006 fez da prática do skate o principal assunto de sua temporada; e também, pelo programa Planeta EXPN ${ }^{17}$, do canal ESPN, que semanalmente traz matérias, vídeos e entrevistas com skatistas tidos como famosos. Ademais, no ano de 2010, foi lançado o primeiro longa metragem nacional sobre skate, intitulado "Vida sobre Rodas", que enfoca a trajetória de quatro importantes skatistas brasileiros da modalidade vertical ${ }^{18}$. Mediante todos esses fatos, Fortes $(2009,421)$ elucida que:

A presença dos esportes radicais na mídia está ligada ao crescimento dos mesmos e à busca de audiência juvenil por parte dos meios de comunicação. Desta forma, não apenas televisão mas também cinema, rádio e revistas abrem espaços inéditos para esportes que antes contavam com pouca visibilidade.

A popularidade do skate em tempos atuais não se expressa somente pela audiência dada à mídia ou pelo retorno financeiro atribuído às muitas empresas que investem em ações direcionadas a sua prática. O Instituto Datafolha publicou em 2010 os resultados de uma pesquisa encomendada pela Confederação Brasileira de Skate (CBSk) ${ }^{19}$, cujo objetivo principal era medir a penetração de praticantes do skate nos lares brasileiros, bem como obter o perfil dos mesmos. A pesquisa foi realizada a partir de uma abordagem pessoal em pontos de fluxo populacional, mediante a aplicação de questionário estruturado.

Os resultados evidenciam que em torno de 5\% dos domicílios brasileiros há algum praticante do skate, sendo que a maioria deles está situada em regiões metropolitanas. Isso demonstra, pois, que a prática do skate é mais difundida nos grandes centros, sobretudo da região sudeste, embora cidades consideradas de pequeno ou médio porte

\footnotetext{
${ }^{16}$ Malhação é uma série televisiva voltada ao público adolescente. Exibida pela Rede Globo desde 1995, a série encontra-se em sua décima oitava temporada. Mais detalhes em: http://malhacao.globo.com.

17 O Planeta EXPN vai ao ar de segunda a sexta-feira, pelo canal ESPN Brasil, a partir das 14 horas. Vide: http://espn.estadao.com.br/planetaexpn.

${ }^{18}$ De acordo com a sinopse do filme, "“Vida Sobre Rodas' conta a história do skate nas últimas décadas através de depoimentos e manobras dos 4 maiores ídolos nacionais da atualidade: Bob Burnquist, Cristiano Mateus, Lincoln Ueda e Sandro Dias. Depoimentos e imagens de skatistas, jornalistas e empresários formam um conjunto que retrata os obstáculos superados pelo skate, hoje o segundo esporte mais praticado no país. 'Vida Sobre Rodas' é um filme de muitas histórias, mas é, acima de tudo, a trajetória de jovens, muitas vezes sem nada em comum além da paixão pelo skate, que transformaram o esporte no país" (Disponível em: http://www.vidasobrerodas.com.br/index2.html. Acesso em 30 de maio de 2011).

19 Resultados mais detalhados dessa pesquisa foram publicados na Revista CemporcentoSkate (edição $15,2009)$.
} 
também tenham apresentado, em relação às pesquisas anteriores ${ }^{20}$, consideráveis avanços no número de praticantes.

No que diz respeito aos aspectos socioeconômicos, a pesquisa ressalta que o skate é uma prática mais comum em classes tidas como mais favorecidas, visto que $42 \%$ dos praticantes situam-se nas classes A e $\mathrm{B}^{21}$. Uma das possíveis explicações quanto a esse dado é o custo considerável para a compra e manutenção dos equipamentos necessários, bem mais caros se comparados aos equipamentos de diversas outras práticas esportivas $^{22}$.

Os resultados também comprovam algo perceptível no universo do skate: a maioria dos praticantes é do sexo masculino (90\% do total). Contudo, o número de praticantes do sexo feminino tem aumentado ano após ano, o que tem implicado no aparecimento de novas categorias, na construção de novos discursos e no posicionamento do skate feminino frente ao universo do skate ${ }^{23}$.

Quanto à faixa de idade, a maior parte dos praticantes situa-se entre 11 e 20 anos, com média de 16 anos. No entanto, o interesse pelo skate começa desde cedo, tendo em vista que $25 \%$ dos praticantes possuem até 10 anos, e se estende até idades mais avançadas, o que pode ser comprovado através da categoria old school, que nos últimos anos tem ganhado cada vez mais força ${ }^{24}$.

Por fim, os resultados da pesquisa publicada pelo Datafolha contabilizam mais de 3.860.000 (três milhões e oitocentos e sessenta mil) pessoas praticantes do skate no Brasil. Esse dado aponta para um aumento de $20 \%$ em relação à mesma pesquisa feita em 2006. É importante salientar que esse número expressivo fomenta o mercado nacional do skate, composto por inúmeras marcas especializadas na fabricação de peças, confecções, calçados, entre outros acessórios que são feitos especialmente para os adeptos e simpatizantes da prática. A demanda é tanta que o mercado especializado brasileiro é considerado auto-suficiente, o que o leva a ser o segundo mais rentável do mundo, ficando atrás apenas do norte-americano ${ }^{25}$.

\footnotetext{
${ }^{20}$ Em 2002 e 2006 também se realizou essa mesma pesquisa.

21 Desse total, $8 \%$ situam-se na classe A, e $34 \%$ na classe B.

22 Por meio de pesquisas em lojas virtuais especializadas, um skate nacional completo custa em torno de $\mathrm{R} \$ 200,00$, enquanto um importado sai por volta de $\mathrm{R} \$ 700,00$.

${ }_{23}$ Para uma análise sobre o skate feminino, vide Figueira (2008). No Anexo B também discuto, com base numa etnografia, algumas questões de gênero no universo do skate pesquisado.

24 A categoria old school abrange os skatistas que praticam há muitos anos, ou seja, os chamados praticantes da "velha escola". Desde a década passada várias competições têm sido feitas em todo Brasil, com foco nos skatistas com idade superior a 35 anos.

${ }^{25}$ Informação divulgada em http://www.cbsk.com.br/pags/dados.htm. Acesso em 22 de março de 2010.
} 
São Paulo, por sua vez, é a cidade que possui mais praticantes do skate no país. A popularidade é tamanha que, segundo uma pesquisa feita pela prefeitura, o skate figura como o segundo esporte mais praticado em escolas municipais, perdendo somente para o futebol ${ }^{26}$. Além do mais, devido à propagação de sua prática ao longo dos anos, o então vereador Alberto “Turco Loco" (PSDB) instituiu, em 3 de agosto de 1995, o Dia Municipal do Skate ${ }^{27}$, comemoração que passou a ser a nível estadual a partir de $2003^{28}$.

Embora muitas vezes incompreendida, é inegável que a prática do skate se difundiu em muitas partes do mundo, seja em uma pista à beira de uma praia californiana, ou até mesmo entre os jovens zulus no território de Kwa Ximba, na África ${ }^{29}$. No entanto, no meio acadêmico, o "skate" ainda se encontra praticamente invisível, fato que pode ser considerado reflexo das pouquíssimas pesquisas feitas que o tratam como objeto.

A antropóloga Simoni Guedes (2010), ao fazer um balanço das produções acadêmicas que se aproximam da temática "esporte, lazer e sociabilidade", reconhece que as análises sobre o futebol sempre foram preponderantes na Antropologia brasileira. Essa constatação pode ser comprovada por meio das muitas pesquisas realizadas sobre o tema ao longo do tempo, entre as quais destaco o trabalho de Guedes (1977), DaMatta (1982), Toledo (2002), Damo (2007), Spaggiari (2009), dentre outros ${ }^{30}$.

Ainda de acordo com Guedes (2010), com o surgimento de diversos outros trabalhos acadêmicos cobrindo variados aspectos das práticas esportivas, ampliou-se “(...) o escopo empírico, introduzindo novas questões, deixando de ser uma Antropologia do futebol para transformar-se em uma Antropologia das práticas esportivas (...)" (Guedes, 2010, 442). Nesse sentido, paulatinamente tem-se uma mobilidade temática, o que reverbera também no alargamento do campo de análises, tornando-o cada vez mais complexo ${ }^{31}$. Em decorrência disso, no contexto brasileiro, a

\footnotetext{
26 Disponível em: http://www1.folha.uol.com.br/folha/esporte/ult92u102808.shtml. Acesso em 30 de maio de 2011.

27 Lei $11.812 / 1995$.

28 Lei 684/2003.

29 Para mais detalhes sobre a prática do skate entre os zulus, vide http://www.indigoskatecamp.co.za/itineary.php. Acesso em 30 de maio de 2011.

30 Para mais detalhes sobre o panorama da produção das Ciências Humanas sobre futebol no Brasil a partir da década de 1990, ver Giglio \& Spaggiari (2010).

31 Simoni Guedes $(2010,450)$ também pondera que "as bases empíricas dos trabalhos se ampliaram bastante na última década, mas permanece a hegemonia dos estudos sobre futebol, que, apesar de justificável devido à extraordinária importância mundial e brasileira desse esporte, ganharia muito se
} 
Antropologia das práticas esportivas passou a acolher pesquisas de várias outras práticas, tais como voleibol, basquete, capoeira, surfe, etc. ${ }^{32}$

Em relação ao skate, até então foram publicadas poucas dissertações ou teses em nosso país, tratando-o especificamente como tema. Um dos trabalhos pioneiros é a dissertação de Ricardo Uvinha (1997), feita para um programa de pós-graduação em Educação Física, que discute, a partir das representações e dos discursos dos skatistas, a questão do lazer na adolescência. Ainda na área da Educação Física, Maria Regina de Menezes Costa (2004) demonstra em seu trabalho como as noções de aventura e riscos são construídas a partir do imaginário social de jovens skatistas. Finalizada um ano após, na área da Educação, a dissertação de Tony Honorato (2005) analisa a relação entre aquilo que considera como "tribo skatista" e as instituições escolares. Leonardo Brandão (2006), por sua vez, optou em pesquisar, para sua dissertação em História, o início do desenvolvimento da prática do skate nos Estados Unidos e no Brasil, no período de 1972 a 1989. Já Billy Graeff Bastos (2006) evidencia, em seu mestrado feito na área de Ciências do Movimento Humano, os "estilos de vida" e as trajetórias sociais de skatistas visando o profissionalismo. Novamente nessa área, Márcia Luiza M. Figueira (2008) trata, em sua tese de doutorado, das representações de gênero que circulam em torno do skate, enfatizando o posicionamento de praticantes do sexo feminino nesse universo. Com análises distantes das que foram apresentadas, Tiago Cambará Aguiar (2008), tendo feito seu mestrado na área do Design, estuda o design gráfico enquanto uma linguagem singular desenvolvida na indústria do skate. Por último, em tempos mais recentes, Mauricio Bacic Olic (2010) defendeu sua dissertação no mestrado em Ciências Sociais, na qual demonstra como os skatistas ressignificam certos espaços da cidade por meio de suas práticas.

Na perspectiva de Guedes (2010, 444), concomitante ao alargamento do escopo empírico das pesquisas feitas sobre práticas esportivas, surgem novas problemáticas teóricas que se expressam em ao menos duas vertentes: "de um lado, diversos trabalhos enfocam o corpo e a corporalidade (...), enquanto outros apontam para a construção de 'estilos de vida' específicos e circuitos de sociabilidade bem delimitados". Embora esta pesquisa seja perpassada por questões inerentes a ambas as vertentes apresentadas, o seu

confrontada com trabalhos que investiguem outros esportes; possibilitando, inclusive, a relativização de algumas proposições".

${ }^{32}$ Vale ressaltar que a utilização da nomenclatura "Antropologia das práticas esportivas" foi proposta por Toledo \& Costa (2009) ao invés de "Antropologia dos esportes", no sentido de ganhar mais mobilidade temática em relação às pesquisas feitas. 
objetivo principal é, sobretudo, analisar as formas de apropriação dos espaços urbanos a partir da prática do skate, e, conseqüentemente, as implicações decorrentes disso. De uma maneira ampla, com efeito, uma pergunta que guiará as análises aqui contidas é: "como os skatistas constroem, simbolicamente, a cidade por meio da prática do skate e de suas experiências como citadinos?"

\section{O skate e a cidade}

Uma segunda geração de praticantes invade as ruas das grandes cidades e transforma o skate no esporte da moda.

Eles tomaram de assalto as grandes cidades brasileiras munidos da mesma força que costuma mover outras animadas "tribos" de jovens que colorem a paisagem urbana, como os roqueiros e os grafiteiros. (...) Sua arma é uma pequena prancha dotada de rodinhas de poliuretano. Trata-se da mais poderosa tribo urbana do momento: a dos skatistas (“A onda de cimento". Veja, 2 de dezembro de 1987, edição 1004, grifos meus).

Essas duas passagens retiradas de uma mesma matéria produzida pela Revista Veja apresentam, de forma um tanto substancial, a prática do street skate, a qual ganhava notoriedade no meio urbano algumas décadas atrás. Ao analisá-las, notamos como certos elementos criam uma imagem, até certo ponto estereotipada, em torno do que vem a ser um praticante do skate e de seus respectivos relacionamentos com os outros. Primeiramente é ressaltada a forma como a cidade é utilizada pelos skatistas: eles "tomaram de assalto" espaços que não os pertencem, os quais não foram feitos para que jovens "armados" com skates fizessem "estripulias" e "peripécias" em cima de suas pranchas. Em seguida, tratando-os como integrantes de uma "tribo urbana" ${ }^{33}$, a matéria poderia nos levar a crer que os skatistas fazem parte de um grupo fechado, homogêneo, até certo ponto rebelde e agressivo. Por fim, já que o skate seria "o esporte da moda", o curioso é a aproximação feita entre skatistas e jovens com certa preferência musical (roqueiros) e artística (grafiteiros), ao invés de atletas, tais como jogadores de futebol e basquete ou até mesmo corredores de rua e tenistas. Estas ambigüidades (onde ora se ressalta o lado esportivo, ora as relações) referentes à prática do skate sempre

\footnotetext{
33 Para Magnani (1992, s/p), a expressão "tribo urbana", tal como usado pela mídia, na verdade não vai além de uma metáfora. Ao crítica-lá, pontua que o termo "não é adequado para designar, de forma unívoca e consistente, nenhum grupo ou comportamento no contexto das práticas urbanas. Pode constituir um ponto de partida mas não de chegada, pois não constitui um instrumento capaz de descrever, classificar e explicar as realidades que comumente abrange".
} 
despertaram minha curiosidade, levando-me conseqüentemente a optar pelo mesmo como tema de pesquisa.

Mudei-me para São Paulo logo após o término de minha graduação em Ciências Sociais pela Universidade Estadual de Montes Claros (Unimontes - MG). Como trabalho de conclusão de curso para essa instituição ${ }^{34}$, pesquisei as formas de sociabilidade entre skatistas a partir de três campeonatos, realizados em distintas cidades, como João Monlevade - MG, Ipatinga - MG e Curitiba - PR. O primeiro campeonato reuniu competidores num plano local, enquanto o segundo, regional e o terceiro, por sua vez, nacional. Desse modo, cada um dos eventos possuía abrangências e importâncias específicas, apesar de guardarem relações entre si: alguns dos interlocutores do campo estiveram nos três campeonatos, e à medida que participavam dos mesmos, ampliavam suas redes de relações.

Após o término dessa pesquisa reavaliei alguns pontos e realizei diversos outros questionamentos sobre a prática do skate, que me permitiram começar a elaborar meu projeto de mestrado. Antes do meu ingresso no programa de pós-graduação, eu pouco conhecia da cidade de São Paulo. Mesmo assim eu queria estudar os skatistas desta metrópole, considerada por muitos a capital do skate brasileiro. Qual seria então o meu ponto de partida?

Sempre que eu acessava a Internet para ler notícias referentes ao universo do skate, não era raro encontrar alguma matéria que divulgava ou fazia cobertura de um evento chamado Circuito Sampa Skate. Durante a leitura, não conseguia imaginar a sua complexidade, pois parecia tudo muito distante e estranho. Dividida em diversas categorias, cada etapa do circuito era realizada em alguma região da cidade de São Paulo e contava com um número imenso de competidores. No entanto, o mesmo possuía uma particularidade: os vencedores das etapas não recebiam nada mais além de troféus e medalhas. Ao contrário, vários outros campeonatos realizados de forma paralela a esse forneciam boas premiações aos vencedores, que podiam ser desde peças para skate, quantias em dinheiro e até motocicletas ${ }^{35}$. Mesmo sem oferecer nada de muito vantajoso, cada etapa do "Sampa" 36 era esperada com ansiedade pelos skatistas ${ }^{37}$.

\footnotetext{
34 Vide Machado (2008).

35 Ao longo do ano 2009 aconteceram vários campeonatos, paralelos à realização do Circuito Sampa Skate. Por exemplo, a cada etapa do Circuito Paulista de Skate Amador oferecia-se uma premiação em produtos para skate (peças, roupas, etc.) equivalente a $\mathrm{R} \$ 9$ mil. Já no Circuito Maremoto, a premiação era ainda maior: em torno de $\mathrm{R} \$ 12$ mil por etapa, além de uma moto, notebook, filmadoras digitais e videogames para os vencedores de certas categorias que disputaram a competição.

36 "Sampa" é a forma que os skatistas chamam, resumidamente, o Circuito Sampa Skate.
} 
Todos esses fatos instigavam-me, levando-me a questionar o que havia de tão interessante nesse circuito, capaz de mobilizar tantos skatistas em uma competição realizada ao longo de um final de semana.

Entre as várias modalidades que fazem parte do skate ${ }^{38}$, o meu interesse voltou-se para a chamada street skate. Como é feito especialmente para essa modalidade, o Circuito Sampa Skate poderia ser um considerável ponto de partida para entendê-la. Portanto, elegi esse evento como lócus inicial da pesquisa, sem deixar de considerar seus possíveis desdobramentos etnográficos.

O projeto de pesquisa com o qual ingressei no mestrado objetivava analisar os múltiplos sentidos atribuídos à prática do street skate a partir da realização do Circuito Sampa Skate. Destarte, ao acompanhar uma série de etapas que fazem parte do circuito, minha pretensão era apresentar o que havia de regularidade e de continuidade nas relações estabelecidas entre os participantes em uma dinâmica que poderia ser vista, inicialmente, como desorganizada e descontínua. Concomitante a isso era preciso entender a heterogeneidade constitutiva do universo dos skatistas, distanciando-me das representações construídas metaforicamente pela mídia ${ }^{39}$. No entanto, com os desdobramentos da etnografia passei a perceber uma atenção especial dada, por parte dos interlocutores, ao contexto espacial onde o skate é praticado, a qual se manifestou por meio de seus discursos e práticas.

Desde a sua consolidação, já em meados da década de 1980, a modalidade street skate, como o próprio nome sugere, possui como objetivo central a prática do skate nas ruas das cidades. Entretanto, "andar de skate" ${ }^{40}$ nas ruas não significa dizer que os skatistas, munidos de seus "carrinhos", circulem por aí dando somente impulsos em asfaltos e calçadas, por entre pedestres, carros, motos, caminhões e outros veículos. Ao contrário, eles transitam e interagem com a dinâmica urbana tendo em vista a procura por picos, isto é, equipamentos urbanos dotados de certas características que possibilitam a prática do skate. Esse termo nativo aparecerá inúmeras vezes ao longo

\footnotetext{
37 Faço esta afirmação com base em recados deixados por skatistas participantes do circuito em comunidades virtuais da Internet. Acesso em 26 de março de 2009.

38 Destaco as mais importantes: street skate (skate nas ruas); vertical (praticada em um half pipe, rampa em formato da letra "U") e downhill (descida de ladeiras).

39 Uma matéria publicada pela Revista Competir (2010, s/p), dizia que o skate “(...) vai além de uma simples prática; engloba uma cultura fiel e um comportamento homogêneo, fechado e uníssono, característica típica da personalidade jovem do século XXI" (grifos meus). Essa aparência de uma homogeneidade entre os skatistas que pretendo problematizar.

40 A partir deste momento, em várias ocasiões usarei "andar de skate", termo nativo que designa a prática do skate.
} 
desta pesquisa, e por meio dele pode-se compreender o que inspira as sessões realizadas pelos skatistas para o exercício de uma prática esportiva, bem como a sociabilidade construída a partir da mesma.

Ao analisar a prática do street skate nas cidades, foi obviamente necessário contemplar a questão do "espaço", sempre um tema caro à pauta antropológica desde os primórdios da disciplina ${ }^{41}$. Portanto, considero o espaço urbano não apenas um pano de fundo onde ocorrem processos de natureza sociocultural ${ }^{42}$, mas também, como algo expresso por meio de um conjunto polifônico de representações e narrativas nativas, conforme frisado por Frúgoli Jr. (2005, 133), ao colocar o urbano em questão na Antropologia. Com efeito, as investigações proposta nesta pesquisa aproximam-se de uma antropologia $d a$ cidade ${ }^{43}$, e não apenas $n a$ cidade, as quais pretendem evidenciar de acordo com a perspectiva de Agier $(2011,38)$ - a cidade vivida, sentida e em processo, o que implica em não considerá-la como uma "coisa", mas como um todo decomposto vivido em situação ${ }^{44}$.

Para dar conta das análises adiante empreendidas, as quais relacionam à prática do street skate aos usos e apropriações dos espaços urbanos, recorro a alguns autores cujas idéias se aproximam do contexto etnográfico pesquisado, com destaque para Georg Simmel (1983 [1908]) e a sua noção de proximidade e distância, Isaac Joseph (2005) e a figura do citadino, Michel Agier (1999) e o conceito de sociabilidades alargadas ${ }^{45}$.

Georg Simmel (1983 [1908]), no começo do século passado já chamava a atenção, em suas publicações, para a dimensão espacial e relacional das cidades através da noção

\footnotetext{
41 Para informações detalhadas sobre as produções que enfocaram a questão do "espaço" na Antropologia, vide Silvano (2010).

${ }^{42}$ Para uma abordagem mais detida sobre a questão do espaço urbano, vide Frehse \& Leite (2010). Esses autores fizeram um levantamento bibliográfico das principais discussões referentes à temática "espaço urbano no Brasil", apresentando diversas concepções sobre o assunto, que são mobilizadas, em termos teórico-metodológicos, de diferentes modos.

43 Michel Agier $(2011,32)$ defende a possibilidade e a utilidade de três aspectos distintos (mas convergentes) como modo de entendimento de uma antropologia $d a$ cidade: os saberes (les savoirs); os espaços (les espaces) e as situações (les situations). Desse modo, o mesmo autor postula que a antropologia $d a$ cidade não se baseia numa definição externa, urbanística, estatística ou administrativa da cidade, mas ao contrário, leva em consideração o seu caráter de uma multitude sem totalidade. Já Magnani $(2002,20)$ ressalta que tanto a antropologia $n a$ cidade quanto a $d a$ cidade, "devem ser considerados como dois pólos de uma relação que circunscrevem, determinam e possibilitam a dinâmica que se está estudando". Para mais referências sobre Antropologia da Cidade, vide Frúgoli Jr. (2007) e Eckert (2010).

44 Para mais informações sobre os desdobramentos e a trajetória do conceito de situação na Antropologia, vide Frúgoli Jr. $(2007,36)$.

${ }_{45}$ O conceito de sociabilidades alargadas, tal como proposto por Michel Agier (1999), será abordado no próximo tópico.
} 
de mobilidade, a qual se manifesta a partir da figura do estrangeiro - ou estranho - 46 como uma forma específica de interação que articula a noção de proximidade e distância nos relacionamentos estabelecidos (Frúgoli Jr., 2007, 16) ${ }^{47}$. Nesse sentido, o indivíduo está concomitantemente perto e longe, condições que se manifestam por meio de uma proximidade corporal e uma distância espiritual. Isso o leva a ter mobilidade não só pelos espaços da cidade, mas também, em suas interações, as quais lhe propiciam um estranhamento, a constituição de formas de associações, a mediações, bem como o conflito com os outros. Partindo dos postulados de Simmel (1983 [1908]), a etnografia do universo do street skate, ao descrever a mobilidade dos skatistas pelas cidades, evidencia esse caráter de proximidade e distância que emerge em meio a uma dinâmica relacional construída a partir do exercício de uma prática esportiva.

Isaac Joseph $(2005,119)$ considera que os espaços públicos - locais onde muitas vezes os skatistas se encontram - podem ser entendidos como a unidade desconcertante de um espaço físico de locomoção e de um espaço abstrato de comunicação. Levando em conta as idéias desse autor, o enfoque desta pesquisa será destinado à figura do citadino (Joseph, 2005), isto é, a um sujeito de mobilidade que faz do espaço público uma espécie de "jornal”, por onde circula, observa e, conseqüentemente, faz a sua leitura ${ }^{48}$. O citadino é ao mesmo tempo um ator e um observador, alguém que se desloca por entre os espaços e, para isso, "precisa de um 'guia' que lhe permita orientarse na justaposição das ordens rituais das quais necessita quotidianamente explorar a possibilidade de acesso" (Joseph, 2005, 120).

Os streeteiros, como muitas vezes se denominam os skatistas adeptos da modalidade street skate ${ }^{49}$, na condição de citadinos, vêem a cidade por meio daquilo que muitos deles chamam de olhar skatista. Essa expressão nativa - que de certa forma pode ser entendida, com base na proposição de Joseph $(2005,120)$, como algo que

46 Frúgoli Jr. $(2007,16)$ aventa que a figura do estrangeiro, ou estranho, personificada no viajante, apresenta "uma representação próxima, em certos aspectos, à do próprio antropólogo".

47 Inspirando-se em muitos conceitos de Simmel, sobretudo no que diz respeito à sociabilidade e mobilidade, certos pesquisadores ligados à chamada Escola de Chicago ressignificaram seus usos a partir de etnografias realizadas no contexto urbano. Segundo Cuin \& Gresle (apud Frúgoli Jr. 2007, 17), eles formularam uma "concepção 'espacializada' do social e, reciprocamente, socializada do espaço". Isso reverberou, a cargo de exemplo, em pesquisas empíricas feitas por Robert Park (1987 [1916]), nas quais a dimensão espacial da cidade exerce importantes influências em suas análises das relações ora estabelecidas. Isso o propiciou a formular a noção de "região moral", que se constitui a partir da articulação entre uma organização física e uma ordem moral de determinados espaços.

48 Para considerações adicionais a respeito das idéias propostas por Joseph (2005), vide Sierra (2005, $\mathrm{s} / \mathrm{p})$.

49 Devido às várias modalidades do universo do skate, todo streeteiro é skatista, mas nem todo skatista é streeteiro. Ele pode ser verticaleiro, freestyler, longboarder, etc. Nesta pesquisa, a partir de então, quando me referir aos skatistas, faço referência aos streeteiros. 
"guia" as práticas desses citadinos - reverbera a percepção que os skatistas possuem dos espaços e equipamentos urbanos; como exemplo, conforme já adiantado, dependendo de suas características os mesmos podem ser considerados picos, os quais se tornam obstáculos a serem superados. Desta forma, um corrimão não serve somente para dar segurança a quem utiliza uma escada, mas também para ser deslizado com o skate. Uma escada não é apenas para se passar de um nível ao outro, mas para ser pulada. Uma escultura não é só para ser olhada e apreciada, mas ao contrário, pode servir como uma inclinação propícia para manobras. Os exemplos se estendem aos bancos, às bordas, às placas de trânsito etc. Portanto, ao circular pelos espaços urbanos e ao ressignificar as finalidades atribuídas aos seus respectivos equipamentos, a cidade ganha novos contornos a partir das experiências dos streeteiros.

Nos "rolês" feitos entre campeonatos, pistas e ruas, os skatistas acessam distintos espaços tendo em mente a possibilidade de realizar manobras, tecer formas de sociabilidade, e estabelecer relações de proximidade e distância que, de acordo com as situações, podem resultar em mediações com outros citadinos. Sendo assim, compartilho a idéia de Joseph de que pensar a cidade:

(...) não é insistir em apropriar-se ou em querer pertencer a um bairro, mas estudar os recursos urbanísticos, os equipamentos e serviços que permitem ao citadino superar o estranhamento de um território pouco familiar e orientar-se em um "universo de estranho" (Joseph, 2005, 80).

Conforme será visto nos capítulos desta dissertação, certos espaços centrais da cidade são considerados palcos de encontros e manobras entre skatistas de várias regiões. Porém, isso nem sempre acontece de forma pacífica. Por conta da possibilidade de repressão a qualquer instante, caso queiram fazer uma sessão bem sucedida em algum pico, os praticantes do skate necessitam criar várias estratégias para utilizá-lo; logo, conforme já apontado por Joseph (2005, 99), os citadinos modulam suas práticas e ajustam suas implicações de acordo com as situações em que estão inseridos. Desta maneira, certos espaços centrais da cidade "são densos não só porque concentram atividades e grupos, mas também porque abrangem várias significações, que ao mesmo tempo se entrecruzam, complementam-se, contradizem-se" (Frúgoli Jr., 1995, 12).

Ainda nessa perspectiva, pois, o espaço público não é um espaço de produção de universais, mas ao contrário, "um espaço de hibridação e de excentramento do qual desconfiamos naturalmente" (Joseph, 2005, 119). E por ser menos um espaço 
consensual, as variadas lógicas atribuídas às apropriações e aos usos de equipamentos urbanos que, a princípio, não foram planejados visando à prática do skate, em muitos momentos podem resultar em conflitos entre skatistas e outros citadinos ${ }^{50}$. De certa forma, o skatista pode se chocar com outros pedestres na calçada, se machucar, bem como danificar equipamentos, muitos deles privados, ao considerá-los como obstáculos. Essas atitudes têm sido motivo de polêmicas em São Paulo, levando muitos agentes ligados ao poder público a tentar medidas rigorosas, como a proibição do skate nas calçadas da cidade. Outros agentes, todavia, entendem que isso não deve ser feito, embora a prática do skate necessite ser regulamentada e disciplinada.

Sem querer apressar uma contextualização mais detida dos usos das ruas por parte dos streeteiros ${ }^{51}$, é necessário compreender por agora que eles influenciaram a formatação e as mediações estabelecidas para a realização do Circuito Sampa Skate. Se para os skatistas a prática do skate em equipamentos urbanos pode se constituir tanto como uma "diversão" quanto um "trabalho", para muitos outros citadinos, ela não passa de um ato de "vandalismo". Para delimitar a prática do skate em uma área reservada para esse fim, a prefeitura tem construído diversas pistas, as quais podem ser encontradas em distintas regiões da cidade. Na visão de alguns agentes ligados ao poder público, construí-las seria, possivelmente, uma boa solução diante as disputas pelos usos dos equipamentos urbanos. Tiago Lobo, coordenador de esportes radicais da Prefeitura de São Paulo ${ }^{52}$, certa vez me disse que "é preciso dar alternativas a eles [aos skatistas]" e por isso, a construção de pistas de skate é necessária. Portanto, para incentivar a prática em locais considerados "próprios", dentre outros interesses, foram criadas algumas ações visando, mesmo que indiretamente, coibir a prática do skate nas ruas. Partindo desse ponto de vista, o Circuito Sampa Skate constituiria, pois, uma espécie de resposta do campo das políticas públicas à intensa propagação do street skate na cidade de São Paulo.

Sendo assim, os organizadores desse circuito, mediante a ampliação daquilo que entendem como cidadania, buscam atingir vários objetivos com sua realização, tais como: influenciar a prática do skate em pistas, o que implica em tirar os skatistas das

\footnotetext{
${ }^{50}$ Contudo, conforme se verá no terceiro capítulo, em muitos momentos há formas de negociações entre os citadinos, que resultam em um apaziguamento dos possíveis conflitos.

${ }^{51}$ De acordo com Frehse $(2009,152)$, a expressão "usos da rua" nos estudos urbanos aparece "por um lado como uma acepção descritiva, por outro, como uma acepção explanatória precisamente de condutas corporais e de relacionamentos sociais nas ruas das cidades alcançadas pela modernidade". Em certo sentido o termo reverbera caracterizações relativas ao comportamento e formas de sociabilidade em lugares públicos.

${ }_{52}$ Mais detalhes sobre esse interlocutor no Capítulo I.
} 
ruas; incentivar a disputa esportiva ao longo de todo o ano; manter a mente dos competidores "ocupada" com critérios definidos de participação, etc. Os skatistas, por suas vezes, em suas condições de citadinos ressignificam os sentidos atribuídos a essa percepção de cidadania, e adotam práticas que ora se aproximam, ora se distanciam dos objetivos dos organizadores.

Embora haja um incentivo à prática do skate em pistas (afinal, as competições acontecem nas mesmas), os participantes nem sempre as utilizam. O que é mais valorizado no street skate, conforme averiguado por meio dos discursos e das práticas dos streeteiros ${ }^{53}$, é saber utilizar de forma criativa os diversos picos encontrados pela cidade. Desse modo, eles participam do Circuito Sampa Skate, elaboram estratégias de competição, aproveitam de tudo aquilo que o mesmo tem a oferecer, mas, nem por isso, sentem-se motivados a andar de skate somente em pistas, ou seja, em um espaço delimitado do ponto de vista institucional. A mobilidade pela cidade é algo importante, e por isso não é raro encontrar esses citadinos transitando por entre as pistas e as ruas, em busca de lugares skatáveis ${ }^{54}$.

De uma maneira ampla, têm sido recorrentes as tentativas de consolidação de políticas públicas que, de uma forma ou de outra, visam disciplinar certas práticas e restringir a sociabilidade tecida em torno das mesmas a espaços definidos de antemão, os quais são considerados, a partir da ótica do poder público, como apropriados para tais fins. Um bom exemplo que merece ser mencionado no contexto da cidade de São Paulo

\footnotetext{
53 As revistas e vídeos especializados em skate são, de acordo com observações e conversas realizadas durante o trabalho de campo, responsáveis por incentivar a prática do skate nas ruas, ou melhor, nos picos. Ao andar de skate e fazer fotos nos mesmos há a possibilidade do skatista aparecer em alguns desses meios de comunicação. A Revista Tribo Skate (Março de 2009, edição 161), em uma matéria intitulada "Avenida Paulista: o passeio nosso de cada dia", chama atenção para o uso criativo dos equipamentos urbanos: "um lugar onde a pedra portuguesa reinou por quase 40 anos, e depois de um ano de interdições e transtornos fora do comum, se tornou o sonho de qualquer ser levemente racional que já pisou em um skate alguma vez na vida. São bordas de mármores de todos os tamanhos, escadas, wallrides, gaps, hidrantes, buracos. Tudo cercado por um chão liso, melhor do que da maioria das pistas da cidade. A simples sensação de atravessar os largos quarteirões remando é indescritível. Mas toda essa perfeição é ofuscada por um simples motivo: a Avenida Paulista não foi feita para o skate". Embora reconheça que essa avenida não é apropriada para a prática do skate, a revista orienta os skatistas a usar do bom senso no momento do uso de certos espaços: "para evitar maiores conflitos, muitos passaram a andar apenas à noite ou nos domingos, sempre dando prioridade para quem está passeando na calçada. Na reportagem que enfoca a Paulista, você poderá refletir melhor sobre os rumos do skate nesta importante via pública e até contribuir para que a convivência com os demais usuários seja sempre a mais pacífica possível. A sobrevivência da arte do skate no tapetão maravilhoso depende de atitudes sensatas e da melhor política de boa-vizinhança" (Revista Tribo Skate, março de 2009, edição 161).

${ }^{54}$ Essa expressão nativa será explicada no Capítulo II.
} 
é a pixação ${ }^{55}$, conforme analisada por Pereira (2005) em sua dissertação de mestrado. Segundo esse autor, há uma série de relações imprecisas entre a pixação e o grafite. Em relação à primeira prática, de modo geral, "o que se vê são apenas rabiscos, garranchos indecifráveis que enfeiam e poluem visualmente a cidade. A pixação é quase sempre apresentada como uma das principais inimigas do espaço público" (Pereira, 2005, 17). Já a última prática tem no desenho e na pintura figurativa os principais meios de expressão. Para Pereira (2005), enquanto a pixação é tida tanto pela mídia quanto pelo poder público como um tipo de sujeira que depreda a paisagem, o grafite, ao contrário, tem obtido o status de arte, uma manifestação que embeleza o espaço urbano.

Por conta de um conjunto de fatores que inclui a aversão aos pixadores, políticas públicas têm sido feitas no sentido de incentivar cada vez mais a prática do grafite. Inclusive, há certas iniciativas, como as oficinas de grafites, cujo intuito é converter pixadores em grafiteiros. No entanto, devido às ambigüidades referentes a essas práticas, os resultados das oficinas podem ser inusitados:

\begin{abstract}
Muitos pixadores acabam aprendendo grafite nestes lugares, mas, sem largar o antigo ofício, continuam a pixar. Há ainda aqueles que não pixavam e que, ao ingressar numa dessas oficinas de grafite, têm contato com a pixação e começam a praticá-la (Pereira, 2005, 20).
\end{abstract}

Logo, em decorrência da etnografia realizada, é possível fazer uma aproximação, com as devidas mediações, entre o universo da pixação e o do street skate. Enquanto os pixadores são considerados "vândalos" por fazerem suas práticas em espaços “inapropriados", os grafiteiros são considerados “artistas”. Da mesma forma, skatistas que utilizam determinados equipamentos urbanos que não foram construídos visando à prática do skate, muitas vezes são considerados "vândalos", enquanto aqueles que praticam em espaços feitos para tal fim, como as pistas, podem ser considerados "atletas" 56. Portanto, certos agentes do poder público tentam converter não só "pixadores" em "grafiteiros", como também "skatistas que andam nas ruas" em "skatistas que andam em pistas". Todavia, essas lógicas dadas a priori não são

\footnotetext{
55 Pereira (2005) adota a palavra "pichação" com a letra "x" tendo em vista que os pixadores a utilizam como uma forma de diferenciá-la do seu significado comumente apontado pelos dicionários. A pixação então, expressa "o modo com que [os pixadores] se apropriam da cidade" (Pereira, 2005, 9).

56 O termo "atleta", conforme será visto nos próximos capítulos, apresenta-se como algo impreciso no universo street skate. A atribuição de tal termo aos praticantes do skate geralmente é feita pela mídia nãoespecializada e pelo poder público.
} 
totalmente compartilhadas por pixadores nem por streeteiros, tendo em vista a multiplicidade de experiências vivenciadas em seus "rolês" pela cidade. Desse modo, as práticas de cidadania que são incorporadas pelos citadinos também podem ser consideradas, com base nos apontamentos de Sierra \& Mesquita (2009) ao fazerem uma revisão dos conceitos de Joseph (2005), como:

Uma questão de urbanidade que revela não uma relação dos cidadãos com o Estado, mas que envolve a participação dos cidadãos nos públicos, sendo estes não apenas os espaços das instituições do Estado, mas todo o conjunto de instituições e serviços urbanos (Sierra \& Mesquita, 2009. Disponível em: http://www.aguaforte.com/osurbanitas9/Sierra_\&_Mesquita_urbanitas-092009.html. Acesso em 11 de junho de 2011).

Isaac Joseph $(2005,96)$ já aventara que a passagem da urbanidade à cidadania não corresponderia a uma consequiência natural. Já o citadino não se reduz à figura do transeunte, e, "tampouco coincide obrigatoriamente com a do cidadão (embora possa vir a assumir tal condição" (Frúgoli Jr., 2007, 7). Nesse sentido, um dos desafios desta pesquisa é demonstrar como os skatistas relacionam suas práticas citadinas às práticas de cidadania a que estão sujeitos (e que buscam ressignificar) na cidade de São Paulo. Portanto, em vez de apresentar uma única lógica em torno do universo street skate, pretendo evidenciar etnograficamente os múltiplos sentidos que o perpassam, os quais, embora em alguns momentos pareçam contraditórios, são contínuos e postos em prática de acordo com a situação.

O Circuito Sampa Skate constituiu uma importante "porta de entrada" no street skate paulistano, através da qual estabeleci uma série de contatos não só com skatistas, mas com um conjunto mais amplo de atores. Ficou claro também que para compreender esse universo, eu não poderia deixar de lado os usos das ruas, visto que elas são evocadas em muitas falas: um interlocutor me disse que o bom skatista "anda em qualquer lugar, em qualquer terreno", ao passo que outro acrescentou que, embora seja importante andar em qualquer lugar, é somente "nas ruas que se anda de skate de verdade". Com base no caráter relacional e situacional do universo pesquisado, os capítulos aqui apresentados abordam o espaço urbano, o qual é "definido pelas vivências associadas à vida citadina" (Meneguello, 2009, 128), dentro de um campo de mobilidade, de circulação e de acessibilidade (Joseph, 2005, 117), o que implica em relativizá-lo como algo fixo e com práticas determinadas. 


\section{Ampliando a rede}

O conceito de redes, apesar de sua recorrência em muitas pesquisas feitas tanto nas Ciências Sociais quanto em muitas outras áreas, tem-se tornado cada vez mais freqüente nas análises de etnografias feitas em contextos urbanos. No entanto, sua utilização na Antropologia não é recente. Há décadas atrás, pesquisadores britânicos ligados à Escola de Manchester ${ }^{57}$ já adquiriam destaque por conta de suas pesquisas produzidas a partir de tal conceito ${ }^{58}$. Em certo sentido, eles rechaçaram a utilização do método genealógico em prol de análises voltadas à compreensão de redes sociais em contextos que passavam por intensas mudanças, em vários planos. Um desses pesquisadores a assinalar é John Barnes (2010 [1969], 175]), que vislumbrava que a noção de rede social, enquanto um tipo de instrumento analítico, está sendo “desenvolvida na Antropologia Social tendo em vista a análise e a descrição dos processos sociais que envolvem conexões que transpassam os limites de grupos e categorias".

Com efeito, ao longo do tempo o conceito de redes foi intensamente questionado, discutido e retomado por muitos outros autores ${ }^{59}$. Mas, nesta pesquisa, o uso de tal conceito faz referência às conexões estabelecidas entre um conjunto amplo de atores ligados, direta ou indiretamente, ao universo da modalidade street skate, sejam eles skatistas, organizadores de campeonatos, representantes do poder público, profissionais da mídia especializada ou empresários. Por meio dessas relações pretende-se evidenciar não só a dinâmica multifacetada que possibilita mediações, mas também a tentativa da legitimação de muitos discursos construídos por certos agentes no que diz respeito à forma e ao sentido atribuído à prática do skate na cidade de São Paulo.

Nesse sentido, em meio a situações marcadas por aproximações e distanciamentos entre os envolvidos, a rede investigada pode ser expressa por meio de escalas medianas

\footnotetext{
57 Para uma discussão mais aprofundada sobre a noção de redes sociais vinculada aos pesquisadores da Escola de Manchester, vide Feldman-Bianco (2010).

58 Feldman-Bianco (2010) ressalta que esses pesquisadores, ao utilizarem em suas análises o conceito de rede, além de criticarem o enfoque funcionalista-estrutural, pautavam-se em muitas indagações, como estas: “'Como estudar aglomerados de pessoas que não formam grupos permanentes?'; 'Como explicar as variações existentes entre o comportamento concreto e as normas e modelos sociais?'; 'Qual a importância de casos 'excepcionais' para explicar as regularidades sociais?’ etc.” (Feldman-Bianco, 2010, 29). A partir dessas críticas, portanto, "há uma reformulação gradativa da pergunta básica da pesquisa antropológica britânica - de 'Como a sociedade se mantém?' para 'Como a sociedade se transforma?'” (Idem, 2010, 35).

59 Entre os quais é válido ressaltar a contribuição de Mitchell (2010 [1956]), Mayer (2010 [1966]), Hannerz (1980) e Latour (2008).
} 
de sociabilidades alargadas, conforme postuladas por Michel Agier (1999). Esse conceito fornece-nos pistas para analisar a maneira pela qual uma pluralidade de atores constrói uma série de mediações que os permitem acessar redes mais amplas de relacionamentos, onde suas escolhas e decisões são seletivas, propiciando-os a estabelecer relações com instituições mais abrangentes, como o poder público.

A partir da realização do trabalho de campo, iniciado em março de 2009, as redes se alargaram. A entrada no universo pesquisado se dera através do "SP Top 40 2008" 60 , evento final do Circuito Sampa Skate do ano de 2008 que, devido a alguns contratempos por parte da organização, teve que ser realizado no começo do ano seguinte. Essa competição é a mais importante de todo o circuito, pois reúne os skatistas que se destacaram e conseguiram ficar entre os quarenta melhores do ranking.

Como eu não tinha ido a nenhuma etapa até então e como também não tinha nenhum contato efetivo com algum participante desse evento, aproveitei a oportunidade para vê-lo de perto. Na ocasião acompanhei o skatista Uriel "Punk", o qual também é editor de um site especializado em matérias sobre skate, chamado Sk8 ${ }^{61}$. Praticante do skate há vários anos, Uriel conhece diversos skatistas competidores do "Sampa", além de outros profissionais envolvidos com a organização do circuito. Desse modo, a partir dele eu pretendia conhecer outras pessoas, que provavelmente tornar-se-iam meus interlocutores da pesquisa.

Chegamos ao evento, que se realizava no Ginásio do Pacaembu. O local estava bem cheio, com a presença de skatistas, espectadores, pais, funcionários da organização, etc. Eu não conhecia ninguém, mas Uriel, pelo contrário, relacionava-se facilmente com vários presentes. À medida que um contato era estabelecido por ele, o mesmo era-me apresentado. Em certo momento conheci Rogério "Tilskater". Pai de skatista, fotógrafo e professor da rede pública, essa pessoa é, sem sombra de dúvidas, uma das que acompanha o Circuito Sampa Skate há mais tempo.

Mas eu ainda precisava conhecer mais pessoas. Meu objetivo no dia era ser apresentado a Márcio Tanabe, um dos principais responsáveis pelo circuito. Porém "Tilskater" alertou-me, dizendo que eu precisaria de sorte para falar com essa pessoa, visto a mesma estar sempre bastante ocupada com o evento. Após isso ele me passou o contato de e-mail de Raphael "Pezão", skatista e videomaker contratado para trabalhar com filmagens ao longo da realização do circuito. Segundo “Tilskater", eu teria

\footnotetext{
${ }^{60}$ Realizado em 29 de março de 2009.

61 Disponível em http://www.sk8.com.br.
} 
possibilidade de acompanhar esse jovem durante todas as etapas, indo e voltando com ele para as mesmas, fato que realmente veio a se concretizar. Fui a inúmeras etapas na companhia de "Pezão", e a partir dele conheci o restante dos funcionários da Skate Contest, empresa organizadora do evento. No entanto, ainda faltava estabelecer contato com Márcio Tanabe. Para minha sorte, em um dado momento do "SP Top 40 2008", notei que ele passava pelo lado de fora da pista de skate. Eu estava na arquibancada e na mesma hora desci os degraus e fui ao seu encontro. Apresentei-me e contei-lhe das minhas intenções com a pesquisa. Ele, por sua vez, foi cordial e se dispôs a ajudar no que fosse necessário.

Já na $1^{\circ}$ Etapa do circuito conheci Tiago Lobo, coordenador de esportes radicais da Prefeitura de São Paulo, representante do poder público responsável por estabelecer a mediação com o universo do street skate. Tiago foi um importante interlocutor, o qual pude entrevistar e ter o contato em alguns momentos do trabalho de campo.

Após conhecer Raphael "Pezão", ele convidou-me por diversas vezes para ir à marquise do Parque do Ibirapuera, um dos locais em que pratica o skate com os amigos. Lá conheci outros skatistas, dentre eles Victor Ferrari, Daniel Santi e Caio Youssef, três ávidos descobridores de picos. Ao mesmo tempo em que andam de skate por vários lugares da cidade, também aproveitam para fazer filmagens de outros skatistas. A intenção deles era lançar um vídeo de skate, e para isso, filmavam manobras em picos diferentes.

Com o passar do tempo entrei em contato com Rodrigo "Bocão", skatista, videomaker e responsável pelo estoque de uma revista de skate. Em sua companhia freqüentei o dia a dia da redação de uma revista acompanhando, na medida do possível, a produção de uma edição, desde a escolha das pautas até a realização das fotos dos skatistas nas ruas. "Bocão" anda de skate regularmente no Vale do Anhangabaú. Convidado por ele, fui diversas vezes a esse ponto de encontro de vários praticantes, que se reúnem todos os dias para andar de skate ou simplesmente ficar na companhia dos outros. E lá no "Vale", para minha surpresa, reencontrei diversos participantes do Circuito Sampa Skate, como Sandro Sobral e Tiago Garcia (skatistas profissionais e juízes da competição), Alexandre "Nicolau", Everton Canuto, André Manto, entre outros. Sem que eu imaginasse, a partir do momento em que passei a acompanhar os 
interlocutores pela cidade ${ }^{62}$, as redes se cruzaram intensivamente, levando-me a descobrir muitos outros espaços, tanto privados quanto públicos, que possibilitam a prática do skate.

Por meio desses skatistas a rede se ampliou, conectando-se a uma série de outras situações para além do circuito inicialmente pesquisado. Diante de uma pluralidade de atores, cenários e distintas posições, o recorte estabelecido não se limitou somente aos campeonatos de skate, tendo se expandido das regiões periféricas (onde cada etapa era realizada) para regiões mais centrais da cidade. Nessas novas formas de espacialidades passei a fazer o trabalho de campo de forma multilocalizada (Marcus, 1995) ${ }^{63}$; logo, minha referência etnográfica não foi um único espaço ou aglutinações de pessoas, mas sim, uma multiplicidade de espaços e de atores que se encontraram articulados por meio de redes mais amplas de relações ${ }^{64}$. Em virtude disso, não trato os skatistas como se fizessem parte um grupo urbano dado aprioristicamente, o qual impõe limites bem definidos e transcendentes aos seus participantes. Apesar de a prática do skate ser individual, ela só tem sentido se for feita em companhia de outros citadinos; portanto, as formas de sociabilidade são permanentemente construídas, constituindo-se de maneiras instáveis e efêmeras. Sendo assim, compartilho dos pressupostos de Roy Wagner (1974) que, ao problematizar a noção de grupos sociais na Antropologia, postula que eles não devem ser tratados como deliberadamente organizados, e por conta disso não devem constituir pontos de partida para as análises. A etnografia, portanto, se centra sobretudo nos processos relacionais que emergiram em certas situações e não na busca de uma unidade nas práticas e nos discursos dos nativos.

A partir da etnografia realizada pretendeu-se descrever, analisar e acompanhar até onde fosse possível o que perpassou as redes criadas através de um evento, bem como traçar as variadas conexões que se cruzaram ou se justapuseram a uma multiplicidade de

\footnotetext{
${ }^{62}$ É importante salientar que a observação participante não foi realizada somente no Parque do Ibirapuera ou no Vale do Anhangabaú. A partir desses locais acompanhei os skatistas por inúmeros outros picos da cidade.

${ }^{63}$ Marcus (1998), de um modo geral, propõe que em uma etnografia multilocalizada deve-se seguir as pessoas, as coisas, as metáforas, os argumentos, histórias, as vidas, os conflitos etc. Portanto, a partir dessa etnografia multilocalizada pretendeu-se revelar uma multiplicidade de conexões e mediações que perpassam o universo do street skate paulistano.

${ }^{64}$ A ampliação das redes de relações no contexto pesquisado pode ser articulada à constatação de Agier (2011, 78), que nos diz que: "é nesse momento que ganha todo o sentido o princípio da articulação das situações na vida dos citadinos, que permite reconstituir a coerência das redes em diferentes ocorrências da vida urbana".
} 
relações estabelecidas entre os atores envolvidos ${ }^{65}$. Desse modo, ao longo desta pesquisa, tem-se a chance de relacionar os distintos recortes inseridos no universo do street skate em São Paulo, sendo esse não definido a priori, mas construído a partir de discursos, práticas e representações heterogêneas, e em meio a uma dinâmica relacional que se manifesta situacionalmente.

O corpo do texto dos capítulos aqui apresentados foi elaborado a partir de minhas anotações feitas após a realização de cada incursão a campo, e sendo assim, na construção textual recorro aos tipos de situações mais regulares. No decorrer da conversação, em muitos momentos o enredo foi ditado pelas visões dos próprios interlocutores. Além disso utilizei, na medida do possível, a câmera fotográfica como um tipo de instrumento comunicacional. Por meio dela fiz diversas imagens, inclusive algumas a pedido dos próprios skatistas, que direcionaram meu olhar para certos fatos que aconteceram no contexto situacional em que estávamos. Ademais, vale a pena ressaltar que a minha experiência vivenciada como praticante do skate durante a adolescência possibilitou-me construir aquilo que Toledo (2009) chama de "olhar treinado" para essa prática esportiva, permitindo-me reconhecer muitas das intencionalidades referentes aos movimentos, às técnicas, aos riscos, aos códigos e às performances inerentes ao universo pesquisado.

Por fim ainda proponho, com o método etnográfico, focalizar fatos muitas vezes "familiares", mas levando em conta uma postura de perto e de dentro ${ }^{66}$, apreendendo os padrões de comportamento, "não de indivíduos atomizados, mas de múltiplos, variados e heterogêneos conjuntos de atores sociais cuja vida cotidiana transcorre na paisagem da cidade e depende de seus equipamentos" (Magnani, 2002, 17). Nessa abordagem etnográfica visa-se, portanto, construir um conhecimento diferente que possa ser concebido por meio de uma relação de alteridade, onde olha-se de outros ângulos para "apreciar a cidade do ponto de vista daqueles que, exatamente por causa da diversidade

\footnotetext{
65 Magnani $(2009,104)$ chega a uma aproximação do que vem a ser etnografia a qual compartilho: "uma forma especial de operar em que o pesquisador entra em contato com o universo dos pesquisados e compartilha seu horizonte, não para permanecer lá ou mesmo para explicar ou interpretar a lógica de sua visão de mundo, mas para segui-los até onde seja possível e (...), numa relação de troca, contrastar suas próprias teorias com as deles e assim tentar sair com um modelo novo de entendimento ou, ao menos, com uma pista nova, não prevista anteriormente".

66 Magnani $(2002,25)$ salienta que em contraste com visões classificadas como de fora e de longe, um olhar de perto e de dentro permite que "ao partir dos próprios arranjos desenvolvidos pelos atores sociais em seus múltiplos contextos de atuação e uso do espaço e das estruturas urbanas, este olhar vai além da fragmentação que, à primeira vista, parece caracterizar a dinâmica das grandes cidades e procura identificar as regularidades, os padrões que presidem o comportamento dos atores sociais. Supõe recortes bem delimitados que possibilitam o costumeiro exercício da cuidadosa descrição etnográfica”.
} 
de seu modo de vida, se apropriam dela de forma também diferenciada" (Magnani, $1993, \mathrm{~s} / \mathrm{p}){ }^{67}$.

\section{Estrutura da dissertação}

A presente dissertação parte da análise dos múltiplos sentidos atribuídos à prática da modalidade street skate na cidade de São Paulo. Por meio da etnografia pretende-se evidenciar não só aspectos em torno do exercício de uma prática esportiva, mas, sobretudo, as implicações em virtude dos usos e apropriações dos espaços urbanos por parte dos citadinos. De uma forma bem ampla, vislumbra-se mostrar como a cidade pode ser lida e ordenada simbolicamente por meio daquilo que muitos interlocutores chamam de olhar skatista.

O primeiro capítulo destina-se à análise do Circuito Sampa Skate. Como já foi dito, para fornecer uma alternativa à prática do skate em locais que não sejam as ruas, o poder público tem construído diversas pistas de skate, principalmente em regiões mais afastadas do centro da cidade. E para incentivar a prática nesses locais "apropriados", têm sido realizadas algumas ações, como o referido circuito, promovido pela Secretaria de Esportes do Município de São Paulo em parceria com uma empresa promotora de eventos. A cada etapa ocorrida, ao mesmo tempo em que possibilita o skatista a participar de uma competição, também o familiariza com outros praticantes que compartilham experiências parecidas, levando-o a explorar a cidade, a redescobrir novos territórios, a situar-se em novos contextos, constituindo assim, redes de relações mais amplas.

Através da sociabilidade que se alarga a partir do Circuito Sampa Skate, a narrativa volta-se para a análise dos diversos lugares skatáveis da cidade ${ }^{68}$. Logo, o segundo capítulo demonstra as mediações políticas que possibilitaram a construção de uma pista de skate em uma região considerada nobre, bem como as formas de sociabilidade constituídas em dois espaços centrais, os quais são apontados pelos skatistas como os mais importantes para a prática. A etnografia, portanto, apresenta as experiências vivenciadas na pista do Sumaré, Vale do Anhangabaú e Parque do

\footnotetext{
${ }^{67}$ Disponível também em http://www.n-a-u.org/ruasimboloesuporte.html. Acesso em 20 de dezembro de 2009).

${ }^{68}$ Termo nativo que será então melhor discutido.
} 
Ibirapuera, locais que constituem pontos de encontro para praticantes de várias partes da cidade.

O terceiro capítulo, por sua vez, evidencia como os picos localizados na cidade são utilizados, tendo em vista a produção de imagens para a mídia especializada. Cada um dos equipamentos urbanos contém certas particularidades que orientam a forma como as sessões são feitas pelos skatistas, as quais geralmente são realizadas em companhia de fotógrafos e videomakers. Além do mais, o capítulo centra-se em muitos discursos construídos pela mídia, que atribuem maior valor ao skate praticado nas ruas, sobretudo em lugares onde a prática não é permitida, em detrimento daquelas feitas em lugares vistos como "apropriados", como as pistas.

Ao final da dissertação, logo após as últimas considerações, também acrescento um glossário de termos nativos, buscando elucidar conceitos e expressões utilizadas ao longo do texto. Além disso, há anexos que demarcam certos desdobramentos da etnografia. 


\section{Capítulo I - Circuito Sampa Skate: o importante é (não) competir}

\section{1 - Circuito Sampa Skate: breve histórico}

O Circuito Sampa Skate é o resultado de uma série de ações contínuas que se deram por meio da parceria entre a iniciativa privada e o poder público. Tudo começou no ano de 2003, quando Márcio Tanabe, um importante empresário do meio do skate, tinha um skatepark na Rua da Consolação. Na época, a cidade de São Paulo contava com poucas pistas de skate. Além disso, as que existiam não possuíam uma boa estrutura. Buracos no chão e equipamentos danificados eram recorrentes. Aproveitandose da carência de locais "apropriados" para a prática do skate e também de um considerável número de skatistas na cidade, Tanabe resolveu investir em seu próprio negócio, que lhe garantia certa estabilidade naquele momento ${ }^{69}$ :

[Eu] ganhava dinheiro praticamente sem fazer muito esforço, porque era um skatepark no centro da cidade. Meu concorrente mais próximo era a Billabong ${ }^{70}$, lá no começo da Rodovia Anchieta, ou, a pista da Saúde, que era pista pública, lá próximo à Billabong. Então aqui, neste raio da cidade, não tinha pista de skate. A gente estava com um negócio próspero (Entrevista em 22 de outubro de 2009).

Toda essa prosperidade foi ameaçada com a notícia de que Marta Suplicy (PT, 2001-2004), então prefeita na época, construiria mais de sessenta pistas de skate espalhadas por diversos pontos da cidade de São Paulo, o que de fato ocorreu. A maioria dessas pistas está localizada nos CEUs (Centros Educacionais Unificados) ${ }^{71}$, equipamentos públicos criados pela Secretaria Municipal de Educação da Prefeitura de São Paulo. Com essa benfeitoria, os skatistas não precisariam mais se deslocar por

\footnotetext{
69 Entrevistei Márcio Tanabe no escritório da Skate Contest, no bairro Pinheiros. Todas as falas desse interlocutor nesta pesquisa são referentes a esta entrevista.

${ }^{70}$ Extinta pista de skate, localizada na Zona Sul da cidade.

71 Os Centros Educacionais Unificados (CEUs) são equipamentos públicos criados pela Prefeitura de São Paulo, durante a gestão da referida prefeita Marta Suplicy, localizados em áreas periféricas da cidade. De acordo com o Guia de Pistas da Revista Cemporcentoskate (2006, 126), cada unidade dos CEUs tem "em média, 13 mil metros quadrados de área construída, reunindo num só espaço creche, escolas de educação infantil e ensino fundamental para 2.460 estudantes. Além disso, elas possuem infra-estrutura completa para atividades esportivas, culturais e de lazer, como teatro, biblioteca, oficinas de dança e música, quadras poliesportivas, salão de ginástica, piscinas, um centro comunitário, área de lazer com pista de skate e um Telecentro com acesso gratuito à Internet e cursos de informática".
} 
longas distâncias para acessar as poucas pistas públicas, nem pagar para praticar em um espaço privado. Observando seus negócios em crise, Tanabe relatou-me o seguinte:

Como empresário, eu observei e falei: “meu negócio vai rodar! Eu preciso buscar uma alternativa!". Qual é a principal alternativa? É a força externa que está influenciando diretamente meu negócio? (...) Se esta força é tão forte que quebra meu negócio, vou procurar esta força e propor uma união. Então, o que eu propus para eles: "você está construindo pistas de skate na periferia. Você precisa dar vida para isto, porque senão uma pista pública é construída, a próxima gestão abandona e a outra destrói”. E destrói porque na gestão do abandono, vai virar ponto de droga. Não porque skatista seja drogado, mas porque a droga faz parte da sociedade e o jovem é vulnerável, está aberto a experiências. O jovem que não anda de skate procura a pista de skate porque é uma área perfeita. Até a polícia parar o carro lá na rua, descer correndo, já dispersou. E ele tem o álibi que é: "estou aqui vendo a galera andar de skate. Não estou aqui à toa" (Entrevista em 22 de outubro de 2009).

Na visão de Tanabe, não bastava somente a construção de um espaço para a prática do skate. Seriam necessárias iniciativas que mantivessem a área em constante atividade, caso contrário, o local poderia vir a adquirir o significado estigmatizado acima descrito, reforçando generalizações como "todo skatista é drogado". Tanabe diz ter visto esta situação inúmeras vezes, em que os espaços destinados à prática do skate viraram pontos de uso e comércio de droga. Em consequiência disso, os próprios moradores do bairro tendem a pressionar o poder público para transformar o local, acabando com o espaço dos skatistas.

Baseado nesse problema, o empresário propôs ao poder público, por meio da sua empresa, a Skate Contest, a criação de eventos nas pistas construídas. Assim nasceu o Circuito Municipal de Skate, evento que consistia em diversos campeonatos realizados em pistas públicas ao longo de todo um ano. Esse circuito, além de promover e estimular a prática do skate em locais "apropriados", também visava identificar skatistas da região onde fosse realizado o campeonato, para que eles trabalhassem com os organizadores do evento. Dessa forma, a intenção era selecionar alguém com certa influência local e fazer dele, segundo Tanabe, uma "espécie de gerente do espaço público". Diante dessa atribuição, a pessoa seria remunerada para ser monitora no ensino da prática do skate a outros jovens: 
Neste evento [Circuito Municipal de Skate] surgiu a idéia de escolher dez skatistas de destaque para iniciar um projeto de capacitação de monitores de skate, parceria entre a ONG Aprendiz e a Skate Contest. Os dez, durante oito meses, passaram por um aprendizado e tornaram-se monitores. Um "monitor" não é bem um professor, é um cara que utiliza o skate com a intenção de trazer outros jovens para uma convivência com a aplicação do conceito de cidadania e integração social. É a educação fora da sala de aula (Disponível em http://skatecontest.com.br/. Acesso em 30 de abril de 2010).

Com o término do mandato da prefeita Marta Suplicy, a iniciativa, que durou dois anos, foi extinta. Na gestão seguinte, do prefeito José Serra (PSDB, 2005-2006) e em seguida de Gilberto Kassab (DEM, 2006-2008), a Secretaria de Esportes pretendeu dar continuidade às políticas públicas voltadas ao skate, visto que esse esporte, segundo pesquisas ${ }^{72}$, é um dos mais praticados entre crianças e jovens da cidade de São Paulo. Após realizarem um levantamento, os representantes da secretaria entraram em contato com o próprio Tanabe ${ }^{73}$, para que o empresário apontasse aquilo que o skate necessitava na época. As pistas, essenciais para a prática, já não eram mais problema. Então, o skatista necessitava de quê?

O que o skatista de São Paulo precisa é saber exercer seus direitos. Ele tem que se tornar cidadão. Se o skate é o segundo esporte mais praticado entre os jovens e se a gente tem diálogo com este cara que anda de skate, seja ele de dez, vinte, trinta, cinqüenta anos de idade, seja ele da classe a, b, c, d ou e, a gente consegue conversar com este cara, então, a gente tem uma ferramenta muito boa para, junto com o poder público, exercer a cidadania.

Não é só fazer um campeonato de skate para o cara. É fazer um campeonato de skate com tudo que ele tem direito (Márcio Tanabe, entrevista em 22 de outubro de 2009, grifos meus).

72 Uma notícia publicada no site da Folha de São Paulo dizia que uma pesquisa realizada pela Prefeitura de São Paulo, "constatou que o skate era o segundo esporte mais praticado nas escolas municipais, perdendo apenas para o futebol. Esses dados chamaram a atenção da então prefeita Marta Suplicy, que, incentivada por uma disputa política, decidiu investir no esporte" (Disponível em http://www1.folha.uol.com.br/folha/esporte/ult92u102808.shtml. Acesso em 19 de abril de 2010).

73 Para Sierra (2005), o discurso dos especialistas - como o de Márcio Tanabe em relação ao skate legitima-se através da competência técnica verificada com base no conhecimento que eles são capazes de demonstrar ou que podem produzir acerca dos problemas urbanos. Com isso eles garantem "um espaço de influência na elaboração de políticas públicas. Trata-se menos de um trabalho vinculado à representação, do que um esforço de planejamento, que envolve o emprego de uma racionalidade capaz de indicar a melhor distribuição e aplicação dos recursos financeiros" (Sierra, 2005, s/p). 
E foi pautado na idéia de cidadania, de utilizar o skate enquanto uma ferramenta de inclusão social, que o Circuito Sampa Skate foi criado. Em vigência desde 2005, o circuito conta com uma série de características distintivas - que serão apresentadas nos próximos tópicos - em relação aos outros eventos de skate. A idéia deu certo, virou referência no cenário brasileiro ${ }^{74}$, e ainda permanece até os dias de hoje, atraindo cada vez mais skatistas provenientes das mais diferentes localidades e em busca dos mais variados objetivos.

\section{2 - Abrindo o circuito: entre skatistas e políticos}

Alguns dias após a realização do "SP Top 40 2008" 75 , finalmente aconteceu a abertura do tão aguardado Circuito Sampa Skate, edição 2009. Vi a divulgação da $1^{\text {a }}$ Etapa na Internet, com todas as informações resumidas. A competição aconteceria nos dias 11 e 12 de abril, na ADC Eletropaulo, Zona Sul da cidade. Combinei de ir para essa etapa junto com Raphael "Pezão" ${ }^{76}$, skatista e funcionário da Skate Contest.

Marcamos de nos encontrar no sábado, na Avenida Paulista, local onde "Pezão" mora. Essa foi uma ótima chance para conhecê-lo pessoalmente, já que o nosso contato era, até então, via e-mail. Eram quase 7 horas da manhã, quando nos encontramos. Tomamos café em uma padaria e fomos para o ponto de ônibus na Avenida Brigadeiro Luís Antônio. "Pezão" estava com um mapa, obtido por meio da Internet, que era nossa única referência. Pegamos o primeiro ônibus, com destino ao Terminal Santo Amaro. Após um curto percurso, chegamos ao local. A partir dali, o objetivo era pegar o ônibus com o letreiro "Varginha" para descer na Avenida Francisco Kennedy. Dessa vez, a viagem foi bem mais longa. Como éramos novatos em São Paulo ${ }^{77}$, o percurso nos possibilitou conhecer um pouco mais da cidade.

Depois de um longo tempo, descemos próximo ao nosso destino. O resto do percurso foi feito a pé. Chegamos ao clube ADC Eletropaulo, localizado às margens da Represa de Guarapiranga. Eram mais de 8 horas da manhã e havia poucos skatistas no local; contudo, praticamente todos os envolvidos na organização do "Sampa” já estavam presentes e trabalhando a todo vapor, uma vez que, de acordo com o cronograma,

\footnotetext{
74 A Revista Cemporcentoskate, edição 98, ano 2006, destacou essa iniciativa.

75 O "SP Top 40 2008” foi realizado no dia 29 de março de 2009, no Ginásio do Pacaembu.

76 Rogério "Tilskater" me passou o contato de e-mail de Raphael "Pezão", o qual se tornou um dos principais interlocutores desta pesquisa.

77 "Pezão" é proveniente de São José dos Campos - SP.
} 
estavam atrasados com a montagem das rampas. Em um canto, estavam os seguranças; em outro, os profissionais da saúde. Ainda havia os trabalhadores responsáveis pelas rampas e também alguns policiais do lado de fora do ginásio.

Assim que chegamos, "Pezão" foi até a pista de skate, para ajudar em pequenos trabalhos. Apesar de ele ser videomaker, dependendo da situação tinha que exercer outras funções. Andando de um lado para o outro estava "Guil, braço direito de Márcio Tanabe (responsável pela Skate Contest), coordenando os outros funcionários envolvidos na organização. Em uma tenda montada logo à frente da entrada do ginásio, estava Paula Araújo, organizando os papéis referentes às inscrições do campeonato. Na pista de skate estava "Borela", ajudando "Gui" a carregar algumas caixas e a fixar alguns banners.

O ginásio fica em uma área privilegiada do clube. No entanto, o espaço não é tão amplo. A pista de skate montada ocupava quase toda a quadra poliesportiva. Atrás das rampas, havia várias caixas de papelão, nas quais alguns grafiteiros convidados expunham as suas artes. Segundo "Pezão", a intenção era que a cada etapa fossem convidados artistas da região para fazer esse tipo de trabalho. Na grade que separava as arquibancadas da pista, foram fixados diversos banners dos promotores: Skate Contest; Prefeitura de São Paulo; 360skate.tv ${ }^{78}$ e ONG AtivAção. Ao contrário de outros eventos, nesse circuito não havia nenhuma divulgação de marcas especializadas em produtos para skate ${ }^{79}$.

Passavam-se os minutos e, pouco a pouco, o número de skatistas no local aumentava. Sentei-me na arquibancada, ao lado de uma mulher e de seu pequeno filho, que prestigiavam a competição ${ }^{80}$. De repente, surgiu um repórter da Rede Globo, junto de um cinegrafista, olhando para a arquibancada à procura de algo. Ele apontou para a mulher e, em seguida, o cinegrafista logo se posicionou com sua câmera à frente da tímida senhora. Sem delongas o repórter tentou entrevista-la. Como ela segurava um capacete, as perguntas diziam respeito aos cuidados com a proteção do filho na prática do skate. Inicialmente estranhei a presença dessa mídia, visto que muitas vezes competições amadoras de skate não são eventos capazes de dar audiência.

\footnotetext{
78 360skate (http://www.360skate.tv/) é um site mantido pela Skate Contest, que reúne alguns vídeos das etapas do Circuito Sampa Skate.

${ }_{79}$ Em outros campeonatos de skate é comum a presença de vários banners, adesivos e outros materiais promocionais de marcas ou empresas apoiadoras do evento.

${ }^{80}$ Cada etapa realizada constitui a oportunidade de despertar o interesse pela prática do skate em várias crianças e jovens. Observei, em diversas delas, a presença de alguns pais com seus respectivos filhos e filhas que, quando chegavam ao local do evento, ficavam fascinados com as manobras realizadas pelos skatistas.
} 
Da arquibancada eu tinha uma vista privilegiada do local. Dentro da pista, a montagem das rampas estava acelerada. Já era para estarem prontas há tempos. De uma hora para outra, surgiu um homem gritando para que algumas pessoas da organização liberassem a pista para os skatistas, o que me surpreendeu. Enquanto isso, vários deles adentravam rapidamente para uma parte daquele local, ansiosos para andar de skate. Não demorou muito para as coisas fazerem sentido. Surgiu uma grande movimentação do lado de fora do ginásio, com a chegada de alguns carros. Notei a presença de fotógrafos, cinegrafistas e repórteres das mais diversas mídias. Instantes após, de um dos carros saiu Gilberto Kassab (prefeito da cidade de São Paulo), acompanhado de Walter Feldman (secretário de esportes) e Tiago Lobo (coordenador de esportes radicais), além de assessores, seguranças e outros profissionais representantes do poder público.

Todas as autoridades, juntamente com a mídia e os funcionários da Skate Contest, dirigiram-se à pista, para a realização da cerimônia de abertura do Circuito Sampa Skate 2009. Aproximei-me da aglomeração de pessoas e fiquei por lá, ouvindo as conversas. Todas as falas eram voltadas para o prefeito. Sandro "Testinha" ${ }^{81}$, locutor do circuito, falava da importância do skate como ferramenta de inclusão social, capaz de mudar a vida de muitos jovens. Pensei em tentar entrevistar Kassab, ou, pelo menos, trocar algumas palavras com ele. Contudo, naquela situação em que o prefeito era o alvo das atenções, eu precisaria de alguma estratégia para conseguir estabelecer um contato. Perguntei ao seu assessor se poderia presentear Kassab com uma revista de skate - a revista estava dentro de minha mochila - e fui incentivado a realizar tal ato. $\mathrm{O}$ assessor chamou o prefeito e, em seguida, entreguei-lhe a revista. Estabelecido o contato, eu não podia perder a chance de fazer-lhe ao menos uma pergunta: "quais serão as ações do poder público voltadas para os skatistas ao longo deste ano?" O prefeito, de forma bem objetiva, apontou para uma pessoa ao seu lado e disse que ela que me responderia. Em seguida, Kassab respondia a uma série de questionamentos feitos por repórteres da Rede Globo, ESPN Brasil e de jornais impressos. Diante a impossibilidade de entrevistá-lo, entrei em contato com a referida pessoa, Tiago Lobo, por sua vez, muito cordial, que me deu toda atenção possível naquele momento. Como a nossa conversa foi um pouco mais

\footnotetext{
${ }^{81}$ Sandro "Testinha" é uma pessoa, segundo os próprios skatistas, muito importante no universo do skate. Além de locutor de campeonatos, ele é colunista de uma revista e realizador de um trabalho chamado "social skate". Há mais de dez anos ele ministra aulas de skate para crianças carentes, sendo a maior parte delas voltada para os internos da Fundação CASA (antiga FEBEM). Todo o seu trabalho em prol da inclusão social através do skate é reconhecido, tanto nacionalmente quanto internacionalmente. "Testinha" já foi premiado inúmeras vezes por conta de suas ações.
} 
longa, assumi a minha posição como mestrando da USP, deixando claro para ele o meu interesse em pesquisar a prática do skate na cidade de São Paulo. Para minha surpresa, o próprio Tiago se interessou pela pesquisa e ainda me convidou para encontrá-lo algum dia na Secretaria de Esportes para possíveis entrevistas ${ }^{82}$.

Com todos reunidos, houve a execução do hino nacional, inaugurando “oficialmente" o Circuito Sampa Skate 2009. Os representantes do poder público, juntamente com os profissionais da mídia, saíram do ginásio após a cerimônia. Os skatistas não demonstraram tanto interesse por suas presenças, e preferiram andar de skate e ficar entre amigos. Alguns, inclusive, faziam piadas com a presença do prefeito: "Kassab, e a saúde?", gritou um skatista.

\section{3 - Skate e cidadania}

O Circuito Sampa Skate é uma ação da Secretaria de Esportes do Município de São Paulo, promovida em parceria com a Skate Contest. Após o relato da abertura do evento, nota-se que nas relações estabelecidas há uma série de agentes atuando como mediadores entre o universo do street skate e o poder público. Entre os envolvidos com a Skate Contest, temos a presença de alguns funcionários que possuem, de uma forma ou de outra, ligação com a prática do skate, como o caso de Márcio Tanabe. Skatista há vários anos, ele também é o criador de uma das primeiras marcas brasileira de tênis para skate (chamada Mad Rats). Além disso, atuou na mídia especializada, possui um skatepark e organiza diversos campeonatos, tanto amadores quanto profissionais. Em uma conversa, o próprio Tanabe definiu seu papel como mediador:

O meu trabalho foi traduzir [para o poder público], digamos, para a forma culta, o que a galera está falando lá fora. Ou então, o que a galera nem fala, porque não sabe como falar, mas está sentindo. Eu acho que traduzo e por isto eles conseguem atender melhor e entender os caminhos (Entrevista em 22 de outubro de 2009).

Esses profissionais, através de suas iniciativas, podem vir a se colocar “(...) localmente como mediadores entre escalas, o que implica competências de tradução, lingüística e cultural, e de acessibilidade, por atuação de redes sociais e políticas de

82 Tive a chance de entrevistar Tiago Lobo na Secretaria de Esportes. Na ocasião ele estava acompanhado de Arthur Soares, seu assessor. Nesta pesquisa, todas as falas de Tiago são provenientes desta entrevista. 
alcance extralocal" (Agier, 2001, 19). As competências dos envolvidos na organização do Circuito Sampa Skate lhes possibilitam um reconhecimento local, proporcionando status entre os skatistas e até renda suplementar ${ }^{83}$, bem como um reconhecimento mais amplo, no qual são legitimados como representantes de uma diferença ${ }^{84}$. Já pelo lado do poder público, temos outros agentes, funcionários da Secretaria de Esportes. A figura-chave para estabelecer a mediação é Tiago Lobo, coordenador de esportes radicais da Prefeitura de São Paulo, responsável por identificar interlocutores no universo heterogêneo do skate que queiram propor iniciativas conjuntas ${ }^{85}$.

Ao construírem o formato do Circuito Sampa Skate ${ }^{86}$, algo evidente para ambas as partes é a preocupação com questões como cidadania e inclusão social, que devem ser proporcionadas aos competidores ${ }^{87}$. Pautado nessas questões, o skatista Rodrigo "Bocão" define, de acordo com sua concepção, alguns pontos importantes do evento:

É um campeonato que abre espaço para uma "pá" de gente que está nascendo aqui em São Paulo, tipo a molecada nova que está começando a se destacar, que quer estar no ranking. Aí você acaba sendo lembrado, e vai ajudando bastante a molecada que está aí na periferia. Tem bastante campeonato em todo qualquer "buraco" de São Paulo (Entrevista em 17 de março de 2010).

$\mathrm{Na}$ mesma linha de pensamento, Rogério "Tilskater" expressa sua opinião acerca do caráter social das políticas públicas voltadas aos skatistas ${ }^{88}$ :

Ele [o Circuito Sampa Skate] inclui realmente o cidadão. Por exemplo, o moleque de São Miguel vai e anda lá. Provavelmente ele nunca mais vai

${ }^{83}$ Certos funcionários da Skate Contest, que trabalharam na organização do Circuito Sampa Skate, são respeitados perante alguns skatistas. É o caso do fotógrafo Rogério "Tilskater" e do videomaker Raphael "Pezão", interlocutores que aparecerão ao longo desta pesquisa.

${ }_{84}$ Vale ressaltar que essa condição de legitimidade nem sempre é compartilhada por todos os skatistas. Em conversas com alguns deles, os mesmos questionaram a representação que não leva em conta os interesses dos próprios skatistas, mas sim, do poder público.

${ }^{85}$ Portanto, o Circuito Sampa Skate constitui apenas uma parte das políticas públicas voltadas à prática do skate na cidade de São Paulo.

86 Embora o esforço em promover ações direcionadas ao street skate, não é raro encontrar skatistas fazendo críticas à atuação do poder público. De acordo com conversas realizadas com eles durante o trabalho de campo, as principais reivindicações giram em torno de dois aspectos: mais pistas e mais eventos. Entretanto, Tiago Lobo questiona essas críticas, ao mesmo tempo em que ressalta a importância de pessoas ligadas ao skate para firmar algum tipo de parceria.

${ }^{87}$ Saliento que, somente propondo e concordando com essa lógica é que a Skate Contest (que de uma maneira geral, representa os skatistas) pôde conseguir a parceria com o poder público.

88 Rogério "Tilskater" é pai do skatista Igor Smith. Além disso, durante um bom tempo do Circuito Sampa Skate 2009, atuou como fotógrafo contratado pela organização, fazendo imagens da competição. 
andar num "Sampa" da vida, ou ele vira um assíduo, como eu já vi vários moleques. Tem vários moleques aí hoje que não vão correr e vieram ver o Igor [skatista, filho de "Tilskater"], que está aí. E eles também correm o "Sampa”. Estes moleques são de Sorocaba. Eu acho que essa inclusão social funciona, mas assim: "eu vou estar com a minha galera, eu vou competir e vou estar numa pista”. Não é uma pista que você vê todo fim de semana (Entrevista em 4 de outubro de 2009, grifos meus).

Realizado desde 2005, o Circuito Sampa Skate é composto por uma série de campeonatos de skate que circulam por diversas regiões - geralmente periféricas - da cidade de São Paulo ao longo de todo o ano, sendo que, em 2009, esteve distribuído por meio de dez etapas, elencadas a seguir: 


\begin{tabular}{|c|c|c|c|}
\hline \multicolumn{4}{|c|}{ Circuito Sampa Skate 2009} \\
\hline Etapa & Local & Endereço & Data \\
\hline $1^{\mathrm{a}}$ & ADC Eletropaulo & Rua Peixe Vivo, 155 - Socorro. & 11 e $12 / 04$ \\
\hline $2^{\mathrm{a}}$ & $\begin{array}{l}\text { Balneário Garcia } \\
\text { D'avila }\end{array}$ & $\begin{array}{l}\text { Rua Armando Coelho e Silva, } 775 \text { - Pq. } \\
\text { Peruche. }\end{array}$ & 25 e $26 / 04$ \\
\hline $3^{\mathrm{a}}$ & $\begin{array}{l}\text { Clube de Regatas } \\
\text { Tietê }\end{array}$ & Avenida Santos Dumont, 843 - Ponte Pequena. & 30 e $31 / 05$ \\
\hline $4^{\mathrm{a}}$ & $\begin{array}{l}\text { Vila Olímpica } \\
\text { Mario Covas }\end{array}$ & Rodovia Raposo Tavares, Km 19,5 - Butantã. & 20 e $21 / 06$ \\
\hline $5^{\mathrm{a}}$ & $\begin{array}{l}\text { Vila Olímpica } \\
\text { Mario Covas }\end{array}$ & Rodovia Raposo Tavares, Km 19,5 - Butantã. & 27 e $28 / 06$ \\
\hline $6^{\mathrm{a}}$ & $\begin{array}{l}\text { Balneário Garcia } \\
\text { D'avila }\end{array}$ & $\begin{array}{l}\text { Rua Armando Coelho e Silva, } 775 \text { - Pq. } \\
\text { Peruche. }\end{array}$ & 11 e $12 / 07$ \\
\hline $7^{\mathrm{a}}$ & $\begin{array}{l}\text { Clube da Turma } \\
\text { M'Boi Mirim }\end{array}$ & $\begin{array}{l}\text { Travessa Maestro Massaino, s/n - Jardim } \\
\text { Angela. }\end{array}$ & 26 e $27 / 09$ \\
\hline $8^{\mathrm{a}}$ & $\begin{array}{l}\text { Clube Escola } \\
\text { Tatuapé }\end{array}$ & Rua Monte Serrat, 230 - Carrão. & 03 e $04 / 10$ \\
\hline $9^{a}$ & $\begin{array}{l}\text { SESI A. E. } \\
\text { Carvalho }\end{array}$ & $\begin{array}{l}\text { Rua Deodato Saraiva da Silva, } 110 \text { - A.E. } \\
\text { Carvalho. }\end{array}$ & 10 e $11 / 10$ \\
\hline $10^{\mathrm{a}}$ & Parque Imigrantes & Rodovia Imigrantes, Km 11,5 - Jabaquara. & 05 e $06 / 12$ \\
\hline
\end{tabular}

O caráter itinerante do circuito foi planejado pelos próprios organizadores ${ }^{89}$, o que de certa forma propicia aos skatistas uma circulação pela cidade, para que conheçam outros contextos para fora dos seus e assim criem vínculos com praticantes de diferentes locais. O competidor Alexandre "Nicolau" pontua, com base em sua experiência de participante do evento, que:

\footnotetext{
É uma oportunidade de você conhecer gente nova, estilos novos, ver o que está acontecendo nos outros lugares, o estilo que os moleques estão andando, com quem eles estão andando (Entrevista em 26 de março de 2010).
}

Mas para atender os skatistas das diversas partes da cidade foi necessário adotar o seguinte critério:

\footnotetext{
89 Além dos objetivos citados, há também a intenção financeira com a realização do circuito: cada etapa realizada requer o aluguel da pista de skate. Portanto, quanto mais etapas forem feitas, mais vezes a pista será alugada.
} 
São Paulo é dividida em trinta e uma subprefeituras. Então a gente fez um mapeamento, pegamos um mapa da cidade e fizemos [as etapas] sempre em subprefeituras vizinhas. Para fazer a região toda. Para não falar: "na Zona Leste, das quinze etapas, têm dez". Não, todas as subprefeituras são atendidas. Para aquele que não tem dinheiro para atravessar a cidade, ele vai a pé, de bike, de ônibus, de carro, de carona, de algum jeito chega... De skate ele vai. Alguma etapa vai passar perto da casa dele. Então ele é democrático também por isto. Ele é democrático porque é gratuito, ele é democrático porque acontece nas pontas, e é democrático porque acontece perto da casa do cara. Mas se ele quiser ir a outro lugar, ele vai (Tiago Lobo, entrevista em 7 de outubro de 2009).

Desse modo, conforme o andamento do circuito há a possibilidade de uma circulação progressiva dos skatistas pela cidade, do ponto de vista do sistema de orientação de cada um. Isso nos leva a pensar, de uma forma mais abrangente, numa fórmula elaborada por Ulf Hannerz (apud Joseph, 2005, 117), que considera que "a cidade não é apenas a acessibilidade acrescentada à diversidade, mas a diversidade na acessibilidade e a acessibilidade na diversidade".

Como forma de incentivo aos skatistas competidores, todos ainda ganham, gratuitamente, um lanche reforçado. Em cada etapa é montada uma barraca em que são distribuídos sanduíches, sucos e doces. Mas para evitar transtornos na hora da distribuição, o skatista deve comprovar que está competindo ${ }^{90}$. Além disso, outra grande diferença do Circuito Sampa Skate em relação aos outros campeonatos são as inscrições também gratuitas ${ }^{91}$. Para realizá-las é necessário que o skatista esteja na parte da manhã ${ }^{92}$, no dia da competição de sua categoria, portando alguns documentos, como carteira de identidade e comprovante de endereço. Após preencher uma ficha cadastral aceitando todos os termos do regulamento, ele está apto a receber a carteirinha de Federação Paulista de Skate (FPS), o que lhe garante legitimidade como competidor.

Se por um lado as inscrições gratuitas possibilitam a participação de muitos competidores, por outro, cada etapa não oferece nenhum tipo de premiação que possa

\footnotetext{
90 A comprovação é feita por meio de uma pulseira que o skatista recebe no momento em que faz sua inscrição para a competição.

91 Em outros campeonatos amadores de skate, os preços das inscrições variam de acordo com a categoria. Em média, oscilam entre $\mathrm{R} \$ 10,00$ e $\mathrm{R} \$ 40,00$.

92 A organização do campeonato é intransigente quanto a alguns aspectos estabelecidos para a realização da inscrição, principalmente em relação aos competidores que tentam fazê-la fora do horário.
} 
ser considerada atrativa. De forma simbólica, dão-se troféus e medalhas aos dez melhores de cada categoria, além de uma camiseta com a logomarca do circuito. Todavia, muitos skatistas fazem questão de ir ao Circuito Sampa Skate, contrariando a idéia daqueles que pensam que a premiação é uma das principais finalidades dos competidores:

Quando eu lancei a idéia, eu me lembro que o $\mathrm{Ed}^{93}$, da confederação, dizia: "Você é louco? Vai fazer um campeonato com inscrição gratuita? Vai ter tanto moleque que você vai levar quinze dias para terminar o campeonato". Bom, eu vou fazer um em cada região da cidade. Eu limitava antes, só podia correr na Zona Leste quem morava na Zona Leste. Teve ano que eu fiz mais de um na Zona Leste, mas o cara podia escolher uma etapa. Cada um podia correr somente uma fora dali. Pelo RG a gente cruzava os dados e identificava alguns "furões". Sempre tinha os "furões". Daí eles viram que não passavam. Aliás, no primeiro ano, o nosso sistema furou várias vezes, e a gente identificava no visual: "Te conheço!" Aí depois a gente veio com um pouco mais de tecnologia que começou a pegar. Tecnologia não, treinamento. Aí a gente abriu geral. O Ed dizia que a gente demoraria dias para terminar o evento. Aí eu disse que não íamos dar prêmio em material: “ah, então ninguém vai correr o seu campeonato!". Então, na verdade é porque as pessoas não estão acostumadas com um padrão. Aquilo que eu conheço me dá segurança. Qualquer coisa nova é muito estranha (Márcio Tanabe, entrevista em 22 de outubro de 2009).

Durante nossa conversa, o skatista Rodrigo "Bocão" apresentou-me, sinteticamente, suas motivações em participar dos campeonatos:

Eu gosto de colar [participar dos campeonatos] porque sempre encontro muito amigo que não vejo há tempo. E estar ali também, andando numa pistinha. É legal você colar num evento, com todo mundo que está com você. Você consegue mostrar seu skate um pouco, para o pessoal ver que você colocou uma manobra nova no pé: “caramba, está andando bem!". É para mostrar o skate, estar ali junto com o pessoal. É mais estar com seus amigos (Entrevista em 17 de março de 2010).

Com base na classificação do skatista em cada etapa, são computados pontos para um ranking, que define os melhores do circuito. Após todas as etapas acontece o "SP

${ }^{93}$ Ed Scander, representante da Confederação Brasileira de Skate (CBSk). 
Top 40" 94, um evento que visa recompensar e incentivar os quarenta melhores rankeados, provenientes de algumas categorias. São escolhidos vinte cinco skatistas do "amador I"; cinco do "amador II"; três do "iniciante"; um do "mirim" e mais cinco convidados pela organização. As mulheres não entram nessa lista, pois há um evento feito especialmente para elas, chamado "Skate Para Meninas Street Show" 95 . Somente nessas competições é que os skatistas têm a oportunidade de ganhar melhores premiações. Os cinco primeiros colocados podem escolher entre um notebook, uma câmera digital ou uma filmadora, como forma de prêmio pela conquista. Além disso, conforme o prêmio escolhido, o skatista ainda ganha um curso profissionalizante, seja de informática, de fotografia ou de edição de vídeo, capacitando-o para a entrada no mercado de trabalho ${ }^{96}$. Há, segundo os proponentes do evento, uma tentativa de promover através do skate, a inclusão social 97 “(...) que contribua para afastar o jovem da ociosidade, das drogas e conseqüentemente do crime" ${ }^{98}$. Ao apontar alguns benefícios do circuito, o skatista Alexandre "Nicolau" afirma:

Eu acredito que [o Circuito Sampa Skate] é uma parada positiva para o skate. É uma coisa que não tem. É um evento com uma estrutura bacana. Tem uma "puta" estrutura que campeonato pago não tem, é uma iniciativa gratuita. Se o cara tem a curiosidade de ir lá e experimentar, ele vai experimentar, vai saber o que é correr um campeonato. E vem pessoal de tudo qualquer lugar (Entrevista em 26 de março de 2010).

A criação do ranking é, de certo modo, uma tática dos próprios organizadores para que os skatistas participantes do Circuito Sampa Skate se sintam motivados a fazer um planejamento de suas atividades ao longo do ano. Não basta somente andar de skate e ir aos campeonatos. É preciso também saber administrar a própria vida como skatista, traçando metas e objetivos bem definidos. A partir do momento em que o jovem

${ }^{94}$ O "SP Top 40" do ano 2009 foi realizado em 19 de dezembro, no Clube Escola Ibirapuera.

95 O "Skate Para Meninas Street Show" foi realizado em 20 de dezembro de 2009, no Clube Escola Ibirapuera.

96 Tanabe afirmou ainda: "estamos preocupados com o futuro daqueles que se tornarão ídolos um dia. Quase todos os skatistas poderiam estar no mercado de trabalho, já que o mercado do skate está carente. O empresário tem o dever de promover o equilíbrio, distribuindo conhecimento" (Entrevista em 22 de outubro de 2009).

97 Conforme as constantes conversas que tive com os skatistas, percebi que nem todos aspiram ser skatistas profissionais. Alguns pretendem se tornar fotógrafos de revistas especializadas, videomakers ou donos de marcas de produtos para skate. Dito de outra forma, o importante é, dentro dessa concepção, fazer algum tipo de atividade que esteja relacionada ao skate. Esses aspectos serão discutidos de forma mais detida no Capítulo III.

98 Disponível em http://skatecontest.com.br/. Acesso em 20 de janeiro de 2010. 
começa a participar do circuito, há uma tentativa de disciplinarização não só da prática do skate, como também, de sua vida pessoal. Por isso, as regras devem ser seguidas a risco e saber se relacionar com elas é essencial. Perguntei a Tanabe que tipos de regras são essas e ele esclareceu:

Regras desde ler o regulamento ${ }^{99}$ : "duas voltas de 60 segundos. Vão para final cinco melhores da eliminatória mais os cinco melhores da semifinal". Que é uma coisa que o skatista tinha mania de não ler (...). Mas no começo do "Sampa", a gente identificava esta dificuldade dos caras lerem o regulamento, de acessar a Internet e escrever os dados na ficha e tal (Entrevista em 22 de outubro de 2009).

O site do Circuito Sampa Skate contém todas as principais informações para os skatistas ${ }^{100}$, que vão desde o calendário com as datas das etapas, resultados, fotos, classificação no ranking até vídeos com a volta de alguns competidores. Aqueles que participam do circuito devem conhecer todas as informações, principalmente suas classificações para, a partir delas, elaborar as estratégias que visem alcançar boas colocações no ranking final. Ao calcular a média dos pontos alcançados, o skatista saberá se precisa tirar melhores colocações nas próximas etapas ou somente se manter como está:

[O skatista tem] que entender o que é descartar resultado, como se faz a conta, como se calcula uma média. O cara vai entender que a aula de Matemática serviu para alguma coisa! E vai servir o tempo inteiro: na hora de comprar um carro, na hora de comprar uma casa, para ele entender quanto vale o salário dele, na hora de planejar a vida dele. É uma brincadeira de planejar a vida. Qual o tempo de vida que o jovem imagina que vai ter? Ele nem imagina (...). Aí você tem um novo jeito de falar isto. Por exemplo: você tem quinze etapas. Das quinze etapas você pontua com seus seis ou sete melhores resultados, e vai descartar os outros. Aí você faz média, pode

\footnotetext{
99 Paula Araújo, skatista e responsável por fazer as inscrições dos competidores do Circuito Sampa Skate, disse-me que muitos deles não lêem o regulamento e assinam assim mesmo a ficha cadastral. Além disso, muitos questionam certas regras do campeonato, sendo que seus critérios estavam expostos. Contudo, segundo Paula, com o passar do tempo os skatistas conscientizam-se da importância da leitura do regulamento, bem como do cumprimento das regras.

100 O site é uma ferramenta muito utilizada pelos competidores: "todos moleques que eu conheço, que participam do Sampa, a gente mantém contato com eles pela Internet. Naquele tempo [referindo-se a 2005] era raro, era difícil. O site Sampa Skate não vende produto, não oferece entretenimento, ele só mostra resultados, rankings e informações do evento que aconteceu. E eu tenho 270 a 300 acessos por dia. É uma média alta” (Márcio Tanabe. Entrevista em 22 de outubro de 2009).
} 
estar entre os quarenta. O Top 40 é formado por vinte cinco daqui... É parecido com uma questão de vestibular (Márcio Tanabe, entrevista em 22 de outubro de 2009).

Propiciar o planejamento e ocupar a mente dos skatistas com objetivos. Essa é a idéia dos organizadores ao criar os referidos tipos de regras. O skate, desse ponto de vista, seria um meio de estimular o raciocínio, de organizar a conduta e de tirar os jovens do ócio. Para o skatista Everton Canuto ${ }^{101}$ :

[O Circuito Sampa Skate] é um projeto social para mostrar para a galera que o skate está em alta, abrindo portas, tem grandes talentos. Abrindo portas para o cara ocupar a mente, ver que o skate não é quatro rodas, o truck e a madeira (Entrevista em 26 de março de 2010, grifos meus).

Rogério “Tilskater" também corrobora com a visão dos organizadores:

De uma certa forma tem uma inclusão social. Você tira alguém da rua, você tira o moleque de alguma coisa que ele poderia estar fazendo errado (Entrevista em 4 de outubro de 2009).

O tempo ocioso, que em outros estudos de práticas esportivas e de lazer é analisado em oposição ao mundo do trabalho, nesse caso se manifesta também em oposição ao tempo escolar. De acordo com Spaggiari $(2009,51)$, em sua dissertação de mestrado sobre a prática futebolística em escolinhas de futebol em regiões periféricas da cidade de São Paulo, existe, na visão de diferentes atores sociais, "um tempo nãoescolar perigoso, estimulador da violência e da desordem, o que exigiria como solução a ocupação do mesmo por meio da prática futebolística", ou, nesse caso, por meio da prática do skate. A rua, portanto, seria o local onde se vivencia o tempo ocioso perigoso. Sendo assim, são comuns políticas públicas com o propósito de "tirar os jovens da rua" por meio de uma prática esportiva ${ }^{102}$. Mas no caso do street skate, como será visto em

\footnotetext{
101 A partir do ponto de vista desses atores pode-se pensar que os skatistas são levados a estabelecer algum tipo de projeto, que "sendo consciente, envolve algum tipo de cálculo e planejamento, não do tipo homo oeconomicus, mas alguma noção, culturalmente situada, de riscos e perdas quer em termos estritamente individuais, quer em termos grupais" (Velho, 2004, 29). Para Gilberto Velho $(2003,28)$ ainda, no nível individual, o projeto "lida com a performance, as explorações, o desempenho e as opções, ancoradas a avaliações e definições da realidade".

102 Diversas iniciativas promovidas pelo poder público visam "tirar as crianças e jovens das ruas" por meio de algum tipo de prática. Hikiji $(2006,24)$, por exemplo, ao analisar o fazer musical por parte de
} 
capítulos posteriores, essa ação pode ter um efeito reverso: em vez de tirar o skatista da rua, incentiva-o ainda mais a ir até ela, para vivenciar certos tipos de experiências compartilhadas no universo da prática em que ele está inserido ${ }^{103}$.

Como parte das políticas públicas voltadas à prática do skate manifesta através do Circuito Sampa Skate, os melhores competidores, com base no ranking final, ainda possuem a chance de pleitearem a Bolsa Atleta, benefício do Governo Federal que concede ao skatista uma quantia em dinheiro por mês para se dedicar ao esporte. A quantia serve, na maioria das vezes, como suporte para ser utilizada em eventuais gastos, como por exemplo, a compra de peças para o skate, viagens, participação em outros campeonatos etc. Portanto, por mais que o circuito não ofereça inicialmente nada de muito vantajoso para os skatistas, ao seu final, aqueles que melhor projetarem as atividades durante o ano, poderão ser recompensados com a premiação do “SP Top 40”, um curso profissionalizante e a Bolsa Atleta.

Após todas as considerações, é possível notar como certas políticas públicas têm sido concebidas especificamente para a prática do street skate na cidade de São Paulo. Tiago Lobo pontua que o poder público tem procurado investir não só em eventos que são meros "espetáculos", mas também na formação de novos "skatistas cidadãos":

É importante assim, não dá para dissociar: "Não. Apoiamos somente eventos ou só tem que ser feito esporte de alto rendimento, de alto nível”. Não. É o que a gente não faz. A gente trabalha nas três instâncias. No esporte educacional, no esporte radical. No skate, a base, as "aulinhas". A gente tem vinte e três Clubes Escolas, que dão aula de skate gratuita, pagas pela prefeitura. Os eventos localizados de pequeno porte, que são os eventos na pista, "eventinho" pequeno, mais regional. Os de médio porte: um Sampa Skate; um SkateBanks; um Universitário; a Virada Esportiva; o Skate no Museu; o Slalom em Interlagos, que são nem tanto para os iniciantes e não são nem tanto localizados. Amador, Pro [profissional] e espalhado, que agrega ao público da cidade e ao público praticante em geral, no país inteiro.

crianças e jovens participantes do Projeto Guri, na cidade de São Paulo, já apontava que no senso comum há uma atribuição de valor negativo ao tempo livre, isto é, ao período fora da escola, onde o momento "ocioso" é entendido como um tempo "perigoso". Em virtude disso, de acordo com a autora, é preciso "ocupar o tempo" das crianças e jovens, é preciso "tirá-los da rua". Nesse sentido, as propostas do Circuito Sampa Skate, embora sejam destinadas a uma prática esportiva, se aproximam daquelas encontradas no Projeto Guri, tal como estudada por Hikiji (2006).

103 Hikiji $(2006,192)$, novamente em sua pesquisa sobre o Projeto Guri, também reconhece que "diferentemente do tempo ocioso - nunca desejado -, a rua é valorizada em algumas formas de sociabilidade juvenil na periferia”. Essa valorização da rua no universo do street skate será analisada no Capítulo II. 
E o de grande porte, que é um investimento mais alto, que dá um retorno de mídia mais alto, que é a Mega Rampa e os X Games (Entrevista em 7 de outubro de 2009).

As políticas públicas para o skate se dão a partir de três instâncias, que vão desde a base (escolinhas de skate em pistas), passando por eventos direcionados aos praticantes, até espetáculos de grande visibilidade, voltados não só para um público skatista. $\mathrm{O}$ Circuito Sampa Skate, dentro dessa concepção fornecida por Tiago Lobo, é um evento de médio porte.

Embora o circuito seja formatado para estimular a competitividade, a partir dele também se tem, na perspectiva dos skatistas, uma situação favorável para socializar e, paralelamente, inserir o jovem no contexto da cidade, uma vez que os campeonatos permitem a ele um contato na vida social de sua localidade e para fora dela, em conseqüência das redes de relações que são tecidas e ampliadas:

Conheci bastante gente. Gente que eu nem imaginava conhecer eu conheci. Troco idéia e tenho um relacionamento até hoje, trocando idéia pela Internet, marcando sessão para fazer alguma foto (Rodrigo "Bocão", entrevista em 17 de março de 2010).

Cada etapa num lugar diferente, situação diferente, é bem bacana. Estive em lugares que nem sonhava em ir. Se não fosse o "Sampa" eu não teria ido (Alexandre "Nicolau", entrevista em 26 de março de 2010).

Levando em conta os discursos dos agentes ligados ao poder público, e também, dos próprios participantes, pode-se concluir que em cada etapa do Circuito Sampa Skate, ao mesmo tempo que se tem a oportunidade de familiarizar o skatista com seus próprios pares, de discipliná-lo, de incentivá-lo a praticar o skate em locais "apropriados", também se torna possível um novo estranhamento, a redescoberta de novos territórios, a inserção em novos contextos, participando de interações que o aproximam ou o distanciam de outros citadinos ${ }^{104}$. Durante diversos finais de semana

\footnotetext{
104 Em sua análise sobre um programa esportivo destinado a comunidades de baixa renda, realizado na década de 1980, Zaluar $(1994,65)$ ressalta que a criação de espaços de sociabilidade resulta na "ampliação do horizonte social dos jovens que acabam saindo do círculo familiar mais estreito, da rede de vizinhos mais próximos, da sua rua ou praça para o bairro, ou seja, de redes de sociabilidade que vão integrá-los à cidade". Essa "ampliação de horizontes" dos jovens participantes do programa esportivo analisado por Zaluar se aproxima, de certo modo, ao alargamento da sociabilidade estabelecida a partir da participação dos skatistas no Circuito Sampa Skate.
} 
de 2009, estive em companhia de alguns skatistas circulando pela cidade de São Paulo. Após o trabalho de campo em uma série de etapas, foi possível perceber algumas regularidades, principalmente nas relações estabelecidas entre eles, as quais busco sintetizar nos tópicos a seguir.

\section{4 - Dentro e fora do ginásio}

Antes da realização de cada etapa do Circuito Sampa Skate a organização do evento divulga um release, contendo informações sobre a competição. A maioria dos skatistas competidores acessa a Internet e por meio dela fica sabendo de todas as novidades. Além do site oficial do circuito, as informações são compartilhadas através de programas de comunicação instantânea (como o MSN) e também por meio de

algumas comunidades virtuais de relacionamentos (como o Orkut) ${ }^{105}$. A partir dos acessos, criam-se vínculos e redes de sociabilidades virtuais que com a realização dos campeonatos ${ }^{106}$, podem passar a ser pessoais ${ }^{107}$.

Após se informarem da realização de uma etapa, os skatistas fazem contatos com alguns amigos, geralmente os que moram próximos, para irem juntos ao local da competição. Marcam um ponto de encontro e a partir dali percorrem o percurso até chegar ao destino pretendido. Muitos skatistas da Zona Norte, quando participam de alguma etapa distante dessa região, adotam a seguinte estratégia: segundo a skatista Mônica Soares, eles se encontram na Rodoviária do Tietê (um ponto central para eles) e a partir dali vão para o campeonato. Se o local é desconhecido, a alternativa é tentar acionar algum contato, no caso algum skatista que more na região do evento e que possa informar a melhor forma de se chegar até lá.

Como muitos não dispõem de automóveis ou de caronas para ir ao Circuito Sampa Skate, a solução é ir de transporte público. Durante o percurso é possível encontrar outros skatistas, e com isso todos se juntam. Tive a oportunidade de ir inúmeras vezes aos campeonatos na companhia deles. E na maioria dos casos, não era combinado. Encontrávamo-nos por acaso. Para ir a $5^{\text {a }}$ Etapa, realizada na Vila Olímpica Mário

\footnotetext{
105 No Orkut (www.orkut.com) há cinco comunidades virtuais dedicadas ao Circuito Sampa Skate. A maior delas conta com mais de 300 membros.

106 As sociabilidades virtuais "são baseadas em laços sociais que giram em torno de interesses particulares, com vínculos sociais escolhidos através de julgamentos em face ao que o outro divulga de si no ciberespaço" (Recuero, 2004, 10).

107 De todo modo, o contrário também é possível: os contatos feitos pessoalmente no Circuito Sampa Skate são mantidos virtualmente. Com isso, as relações passam a ser tanto virtuais quanto pessoais.
} 
Covas (Zona Sul), combinei de acompanhar Raphael "Pezão". Encontramo-nos na Rua da Consolação para, a partir dali, pegarmos o ônibus que nos deixasse próximos ao local do evento. Mesmo com todas as informações anotadas em um papel, estávamos um pouco apreensivos e com medo de algo dar errado. Teríamos que descer em uma movimentada rodovia e ainda caminhar um longo pedaço até chegar ao campeonato. Um pouco em dúvida, pegamos um ônibus. Da porta observamos uma pessoa acenando para nós: era Rogério “Tilskater”, que também ia para o mesmo destino. "Ufa, que alívio encontrar ele aqui!", comentou "Pezão". No trajeto ainda entraram dois skatistas (um era da região central de São Paulo e outro era de Jundiaí) no ônibus, que sem nos conhecer, nos reconheceram como pessoas que iam para o mesmo destino deles. Todos então observavam a cidade, faziam comentários sobre lugares que possibilitavam a prática do skate, lembravam dos skatistas que moravam em certas regiões. A sociabilidade começa a ser tecida antes mesmo de se chegar ao "Sampa".

Ao chegar ao local do evento, os skatistas vão direto para o espaço que lhes interessa. Não é tão difícil identificá-lo: devido ao eco produzido no interior do ginásio, basta seguir o barulho do skate batendo na madeira. Já no ginásio, antes de qualquer outro ato, é importante ser cordial e cumprimentar aos outros, mesmo os desconhecidos, pois esse é um dos códigos bem vistos entre eles, o que denota humildade por parte do skatista. É lógico que não se cumprimenta a todos do campeonato, mas pelo menos aqueles que estão ao redor ${ }^{108}$. Após o reconhecimento da área e das pessoas, é preciso confirmar a participação na etapa. Com isso, o skatista dirige-se à tenda onde se fazem as inscrições. Preenchidos os dados em uma folha, o competidor recebe a sua pulseirinha colorida. Cada cor corresponde a uma categoria disputada, o que facilita o trabalho tanto do competidor, que fica ciente do momento da sua volta, quanto da organização, principalmente os seguranças ${ }^{109}$, que conseguem identificar quais skatistas estão na pista fora de hora.

\footnotetext{
108 Ao lado de Raphael "Pezão", eu também participava dos cumprimentos recíprocos: cumprimentei vários skatistas, assim como fui cumprimentado por diversos desconhecidos.

109 Entre seguranças e skatistas há tipos de relações que, de acordo com a situação, variam entre a cordialidade e a repressão. Como alguns seguranças trabalhavam no circuito há tempos, os mesmos criavam vínculos de amizades com certos skatistas. Para alguns envolvidos com a organização, as relações atrapalham o trabalho dos seguranças, pois segundo eles, esses profissionais "davam algumas brechas" e não se importavam com certas condutas dos skatistas. Inclusive, em uma etapa senti falta da presença de uns seguranças. Perguntei a Raphael "Pezão" o que poderia ter acontecido e ele me disse que Tanabe provavelmente estaria insatisfeito com o trabalho realizado por eles, e que por isso tiveram que ser substituídos por outros seguranças que, por suas vezes, não tinham nenhum vínculo com os skatistas e que poderiam ser mais rígidos e impessoais no exercício de suas funções.
} 
Cada etapa é realizada durante um final de semana. Conseqüentemente, cada dia (sábado ou domingo) é destinado a algumas categorias, referentes ao grupo disputado ("juniores" ou "amadores"). A parte da manhã é reservada ao aquecimento ${ }^{110}$. Para evitar tombos e trombadas é necessário, nesse momento, restringir o número de competidores na pista. Segundo os organizadores, pode ser perigoso muitos deles andando em um espaço com poucos obstáculos, e por isso deve ser feito o rodízio de skatistas.

O local só começa a ficar cheio próximo ao meio dia. Geralmente os skatistas chegam juntos ao campeonato, mas a partir daí, novos arranjos em seus relacionamentos são criados. Encontram-se skatistas de diferentes bairros ou até mesmo de outras cidades que se conheceram em campeonatos anteriores. Encontram-se também alguns contatos feitos online. E mesmo muitos desconhecidos passam a ser reconhecidos, quando se faz parte dessa dinâmica. O simples fato de se estar ali, junto de outros que compartilham de gostos e de experiências parecidas, é um pressuposto para a criação de vínculos entre muitos que nunca se viram, tal como observado na seguinte situação: nas dependências do Clube Tietê havia, próxima ao ginásio, uma lanchonete. Raphael "Pezão" estava com fome e me chamou para ir até lá com ele. Após pegar o seu lanche, sentamos em uma mesa do lado de fora da lanchonete. Alguns instantes depois chegou Felipe Nery, que nos cumprimentou. Enquanto eles comiam apareceu Pedro Volpi, amigo de "Pezão", que também nos foi apresentado. Ficaram os três skatistas, naquela ocasião, conversando sobre tantos assuntos relacionados ao skate que nem parecia que tinham acabado de se conhecer.

Antes da competição começar, muitos skatistas preferem ficar do lado de fora do ginásio, aproveitando as dependências do local. Enquanto alguns se sentam em qualquer canto na companhia de outros, há aqueles que optam por andar de skate em equipamentos do clube ${ }^{111}$. Essa última prática, na maioria das vezes, é proibida. Assim que o skatista começa a fazer manobras em certos locais como, por exemplo, alguns bancos, logo os outros o vêem e tentam fazer o mesmo. Caso a prática traga danos ao equipamento, como a possibilidade de quebrá-lo, rapidamente aparecem seguranças

\footnotetext{
${ }^{110} \mathrm{O}$ tempo de aquecimento, na parte da manhã, não é dividido entre as categorias participantes do campeonato. Skatistas de categorias diferentes podem dividir o mesmo espaço nessa situação.

${ }_{111}$ No campeonato realizado no Clube Tietê, a skatista Mariana Nunes fazia algumas manobras em um banco feito de ardósia. Caso algum funcionário do clube visse esta prática, certamente a proibiria, visto que a ardósia estava sendo danificada.
} 
para coibi-la. Mas basta eles virarem as costas para que os skatistas comecem a andar de skate novamente.

Na $3^{\text {a }}$ Etapa, realizada no Clube Regatas Tietê, presenciei estas situações: assim que cheguei ao evento vi vários skatistas na porta do ginásio conversando, arrumando as peças do skate, deitados na grama, comendo ou namorando. E também havia aqueles que aproveitavam algumas áreas para andar de skate. Com um número considerável de skatistas no mesmo espaço, cabia aos seguranças banir a prática naquele local. Eles chegavam e explanavam as razões para não andar ali: o skate poderia bater em alguém que passasse, ou, então, poderia estragar o piso. No momento os skatistas acatavam o pedido, mas não demorava muito tempo para que alguém começasse a andar de skate de novo, motivando os outros a fazer o mesmo. De toda forma, a organização do campeonato preocupa-se com certas atitudes dos participantes a partir do momento em que eles estão naquele recinto, pois qualquer conduta considerada "desordeira" pode trazer algum tipo de complicação com outras instâncias ${ }^{112}$, propiciando uma má imagem aos skatistas:

Eu estava numa conversa informal com uma diretora da secretaria [de esportes], já sete e meia da noite. Aí chegou um diretor de clube da Zona Leste. E aí a diretora vira e fala: "ô fulano, e o Sampa Skate, vamos levar uma etapa do Sampa Skate para lá este ano?". Ele vira e: "Deus me livre. [Os skatistas] quebraram tudo lá no ano passado. Aqueles meninos, ninguém segura!". Eu falei: “quebraram o quê?”. "Quebraram meu piso!". "Seu piso quebrou e eu pus novo, hein!". "Ah, você! Nem lembrava de você!”. Aí ele me cumprimentou e [disse]: "Ah, estou brincando". Então vamos deixar claro: realmente quebraram o piso. A molecada andou no piso de cerâmica, que estava mal colocado, tinha bolha de argamassa por baixo. Tecnicamente, em linguagem de pedreiro, a argamassa foi "chutadinha" na economia. Aí bateu e quebrou. O que eu fiz? O cara lá mesmo tinha o estoque desse mesmo piso. Eu comprei a argamassa, contratei o pedreiro e reformei todo o piso externo do ginásio. Além disso, troquei as telhas, porque tinham goteiras. Troquei as telhas antes do evento para não ter goteira. Fiz benfeitorias para o ginásio do cara, e ele vai lá "queimar o filme" (...). Mas você vê o preconceito. A gente

\footnotetext{
112 Ao chegar ao Clube Tietê, encontrei a skatista Jennifer Santos. Após nossos cumprimentos fomos para o ginásio. No caminho avistei uma piscina. Como estava calor no momento, perguntei a ela se os skatistas já nadaram ali. Ela me disse que durante uma etapa alguns competidores tiveram a oportunidade de nadar, mesmo sem autorização do clube, visto que o único espaço com acesso permitido a eles era o ginásio. O fato gerou alguns problemas, por conta da transgressão das regras. Segundo Jennifer, "em eventos da prefeitura não pode dar problemas, pois corre o risco de não ter mais etapas em certos locais".
} 
ainda enfrenta preconceito. Se eu não estivesse lá para me defender, ele teria dito que os skatistas quebraram tudo (Márcio Tanabe, entrevista em 22 de outubro de 2009).

A competição é demorada e pode durar horas, dependendo do número de inscritos. Essa longa espera pode ser cansativa. Com isso os skatistas possuem tempo de sobra para fazer aquilo que quiserem. Ver revistas de skate é um bom exemplo. Basta alguém começar a folheá-las para que outros se sentem ao lado ${ }^{113}$. Ao ler as matérias, todos comentam sobre as manobras, os anúncios, as fotos, as curiosidades, os novos talentos etc. Caso algum dos skatistas conhecidos por eles apareça nas páginas das revistas, o mesmo passa a ser prestigiado pelos demais. Durante a $5^{\mathrm{a}}$ etapa, um competidor folheava uma revista até que, em dada seção, encontrou a foto e uma pequena entrevista com a skatista Fernanda Valiati, participante da categoria "feminino II". Após isso, o garoto juntamente daqueles que estavam com ele, aproveitando da presença da própria Fernanda, cumprimentaram-na pela importante conquista. Ela, por sua vez, contou aos presentes tudo aquilo que foi feito para a produção da foto, desde o contato com o fotógrafo até o momento em que se realiza a manobra. Ainda segundo Fernanda, a partir da repercussão da matéria ${ }^{114}$, ela conseguiu um patrocínio que lhe forneceria peças para seu skate.

Para manterem-se aquecidos, muitos skatistas tentam manobras em algum espaço do ginásio que tenha a superfície lisa. Em etapas, como as realizadas no Clube Escola Tatuapé, havia um amplo espaço para isso. Embora não fizesse parte do tempo da competição "oficial", ali entre eles, havia também uma disputa onde cada um tentava “mandar as manobras" mais difíceis possíveis ${ }^{115}$, chamando a atenção dos outros para seu nível técnico. Aqueles que eram considerados os melhores, por conta da técnica, permaneciam no centro do espaço para que fossem notados, ao passo que aqueles que não sabiam tantas manobras, ficavam às suas margens. Nesses espaços, ainda muitas vezes utilizados de forma improvisada, é preciso seguir alguns códigos de conduta não

\footnotetext{
113 Durante o trabalho de campo, em alguns momentos também passei a ler revistas de skate na arquibancada. Em todas as situações, sem exceção, vários skatistas vieram ao meu encontro, para ler a revista junto comigo ou para pedi-la emprestada. Após o empréstimo, a revista nunca retorna via a mesma pessoa da qual é emprestada. Ao circular pela arquibancada, a revista passa de mãos em mãos, e só depois de algum tempo que ela é entregue ao seu respectivo dono.

114 Sair em revistas especializadas também possibilita status ao skatista perante os demais. Mais detalhes serão apresentados no Capítulo III.

115 "Mandar manobras" é uma expressão nativa. Em linhas gerais, a expressão designa as manobras feitas por um skatista. A partir de agora usarei a mesma por diversas vezes, tendo em vista o sentido apresentado.
} 
estabelecidos de antemão, mas logicamente perceptíveis a partir do momento em que se está ali. É importante, principalmente, respeitar as manobras dos outros skatistas. Atrapalhar alguém fazer sua manobra constitui um desrespeito, uma atitude mal vista entre eles ${ }^{116}$.

\section{5 - Um olhar para a arquibancada}

Ao entrar em um ginásio e ver a arquibancada repleta de skatistas pode-se imaginar que todos ali se vistam, ajam e pensem de maneira parecida. De longe, aquela coletividade parece homogênea. Mas através de um olhar de perto e de dentro (Magnani, 2002) é possível observar uma série de particularidades que revelam a heterogeneidade e a dinâmica relacional e situacional constitutiva da totalidade de skatistas presentes nos campeonatos. Os princípios regulamentadores das relações estabelecidas entre os skatistas durante o Circuito Sampa Skate se dão a partir de três aspectos principais ${ }^{117}$, a saber: a preferência musical; a localidade da qual o praticante do skate é proveniente; e a categoria disputada na competição. Vejamos em seguida algumas considerações.

\subsection{1 - Preferência musical}

A preferência musical dos skatistas é das mais diversas. Por mais que se tente definir de uma forma geral qual é o estilo de música preferido por eles, a resposta nunca será fruto de um consenso. Muitos skatistas escutam de tudo um pouco, desde o samba até o heavy metal. No entanto, levando em conta a história do skate há dois tipos de sons que se destacam ${ }^{118}$ : o rock e o rap ${ }^{119}$. Enquanto na década de 1980 as bandas de rock - em especial as de punk rock - eram cultuadas, na década 1990 a preferência se

\footnotetext{
116 Porém, tudo depende do tamanho do espaço onde se anda de skate: caso ele seja de dimensões amplas, é possível que todos andem juntos, sem atrapalhar uns aos outros. Para mais detalhes sobre as regras construídas pelos próprios skatistas para a utilização de espaços para a sua prática, como as pistas, vide Olic $(2010,72)$.

${ }^{117}$ Pode haver outros aspectos, mas esses três foram os mais regulares durante a realização do trabalho de campo.

118 Para mais informações sobre aspectos da história do skate no Brasil, bem como a sua relação com a música, ver Britto (2000).

119 O diálogo e a interação com outros fenômenos emergentes no meio urbano propiciou ao skate se articular com outras práticas que “(...) também têm no espaço público sua área de atuação, como por exemplo o movimento punk, na década de 80 e o hip-hop, na década de 90 . Estas relações se expressaram na forma diferenciada de se vestir, falar e comportar por parte dos jovens skatistas" (Olic, 2003, s/p).
} 
voltou para os grupos de rap. Atualmente tanto um quanto outro estilo divide as opiniões, mas longe de representar o gosto dos skatistas como um todo.

Sandro "Testinha", locutor do circuito, também é responsável por comandar as músicas que são tocadas durante a competição. O skatista tem a chance, na hora de sua volta, de levar seu aparelho digital sonoro para que sua música predileta seja tocada. Caso não o faça, não é raro ver "Testinha" perguntando: "rock ou rap?". Cada um desses estilos de músicas influencia até a forma do skatista se vestir ${ }^{120}$. Enquanto aqueles que preferem rap tendem a usar calças largas e folgadas, bonés abas retas e camisetas tamanho XXL (extra extra large), os que preferem rock geralmente usam calças e camisetas justas no corpo e tênis vulcanizados. Vale ressaltar que essas representações são substanciais, com base nas observações realizadas, e que não dão conta de definir o que vem a ser mais representativo na constituição do estilo de um skatista, visto que ele é múltiplo e inacabado. De toda forma, são informações interessantes para pensar em como determinadas formas de sociabilidade são organizadas conforme a preferência musical do skatista e, conseqüentemente, sua roupa usada $^{121}$.

Durante a $4^{\mathrm{a}}$ Etapa, realizada na Vila Olímpica Mário Covas, era perceptível o relacionamento entre aqueles que se vestiam de forma parecida: em um canto estavam os skatistas com roupas mais justas (skatepunks) e, em outro, aqueles que se vestiam com roupas mais folgadas (os gangueiros). Ainda havia, com menor visibilidade, os rastas, com dreads nos cabelos ou com roupas nas cores da bandeira jamaicana (verde, vermelho, amarelo e preto) ${ }^{122}$. Cada uma das aglutinações era composta por poucos integrantes que compartilhavam, além do skate, um gosto musical. Sendo assim,

\footnotetext{
120 Faço essa afirmação com base nos fatos e discursos recorrentes durante o período do trabalho de campo. Apesar da generalização, é importante expressar a opinião do skatista Alexandre "Nicolau", que salienta que o estilo de música não determina o modo do skatista se vestir: "se fosse por influência musical, eu nem sei como eu andaria. Seria bizarro. Gosto de tudo. Para mim som bom é: jazz, soul, rap, hardcore, reggae... Não tenho preconceito" (Entrevista em 26 de março de 2010). Por outro lado, o skatista Jorge Costa acredita, assim como a maioria dos skatistas com quem eu tive contato, que o estilo musical exerce uma importante influência: "para a grande maioria, que é mais jovem, mais fácil de ser moldada, geralmente eles se moldam através do estilo musical". Ele ainda cita um exemplo: "quem ouve punk usa roupa menor e preta, usa umas correntes, umas coisas meio estilo punk mesmo" (Entrevista em 19 de março de 2010).

121 As próprias marcas de skate, levando em conta a heterogeneidade de estilos, produzem os mais variados tipos de roupas para atender a demanda em virtude das representações dos skatistas, como os skatepunks, gangueiros e rastas.

${ }^{122}$ De um modo geral, rastas são aqueles skatistas que possuem o reggae como preferência musical.
} 
skatepunks, gangueiros e rastas são algumas das várias representações nativas que levam em conta as músicas ouvidas e as roupas usadas ${ }^{123}$.

Alguns elementos específicos da vestimenta do skatista podem aproximá-lo ou distanciá-lo de outros. Essa é uma forma de marcar a diferença entre eles ${ }^{124}$. Estar junto de outros que compartilham um mesmo gosto musical e um mesmo estilo estético é tornar ainda mais restritos os códigos e símbolos e conseqüentemente o acesso a uma rede de relação. Além de trocarem experiências sobre coisas relacionadas ao skate, o diferencial é que nessa forma de sociabilidade entra a variável música: os skatistas atualizam o que acontece de novo no cenário musical que apreciam, expressam seus gostos por determinadas bandas, sugerem aos outros as suas próprias preferências e pontos de vista.

\subsection{2 - Localidade}

Cada competidor do Circuito Sampa Skate é proveniente de uma parte da cidade de São Paulo, ou, até mesmo, de fora dela. Como vimos anteriormente, durante o trajeto de ida para a competição os skatistas que moram próximos permanecem juntos, compartilhando experiências e códigos específicos construídos a partir de um contato mais intenso. Para afirmar as relações, muitos deles criam as chamadas crews ${ }^{125}$, ou seja, uma forma de associação constituída por aqueles que se consideram amigos e que estão sempre juntos, seja andando de skate ou participando de outras atividades.

Ao longo do Circuito Sampa Skate observei a presença de várias crews, que tinham a localidade como referência para suas formações ${ }^{126}$. Nesse sentido, cito três: o Butanclan ${ }^{127}$, composta por skatistas da Zona Sul da cidade; a TRV Crew ${ }^{128}$, amigos da Zona Leste da cidade; e a Mogi Crew, da cidade de Mogi das Cruzes. As três eram as

123 Além destas, pode haver várias outras representações para os skatistas que curtem, respectivamente, rock, rap, reggae.

124 Ao construírem determinados estilos, os skatistas, ao mesmo tempo tendem à diferenciação e mudança, quanto à igualdade e união, dentro ou fora do grupo (Waizbort, 2000, 186). Como a tendência à variedade é bem forte, em virtude do crescente processo de urbanização, tudo isto é refletido entre os skatistas, que criam suas distinções, provando que eles, ao contrário da visão passada pela mídia, por exemplo, são heterogêneos.

125 Cada crew leva um nome, escolhido mediante o consenso dos próprios participantes.

126 Não obstante, nem sempre as crews são formadas por skatistas que moram em localidades próximas. Pode haver outros tipos de referências. Nesse caso, com base no trabalho de campo, a referência que faço a crew é em termos espaciais.

127 O Butanclan é uma crew de amigos que sempre se encontra na pista de skate do CEU Butantã. Mais informações podem ser vistas em Olic $(2010,59)$ e através da página: http://www.butanclan.com.br.

128 A TRV Crew possui um blog (http://terrivelscrew.blogspot.com/) onde os skatistas divulgam algumas fotos e vídeos. 
mais expressivas, tanto em número de participantes quanto em visibilidade. Em uma das etapas, realizada perto do bairro do Butantã, muitos integrantes da crew Butanclan estiveram presentes para competir. O locutor "Testinha", para interagir com eles, mandava algumas mensagens direcionadas à crew. A TRV Crew, por sua vez, possui uma bandeira em pano preto com a inscrição de seu nome. Durante algumas etapas foi possível observá-la, seja nas mãos dos skatistas, seja pendurada em alguma grade. Outros skatistas expressam o nome da crew de que fazem parte na lixa do skate, ou até mesmo, a exemplo da Mogi Crew, em suas camisetas. Observa-se, mesmo que indiretamente, uma competição simbólica em torno da visibilidade de cada crew nos campeonatos.

O pertencimento a uma crew não implica na ausência de relação com outros skatistas ou até mesmo com outras crews. Durante a competição, com a presença de competidores provenientes de várias localidades, as relações se tornam mais efêmeras $^{129}$, o que possibilita um contato mais amplo. Há, inclusive, trocas entre crews diferentes ${ }^{130}$, principalmente simbólicas, em que experiências sobre a prática do skate na localidade de cada um são compartilhadas. Enquanto estão juntos, os skatistas dão dicas uns para os outros de locais conhecidos em que é possível andar de skate, como vários equipamentos públicos espalhados pela cidade, além de combinar de visitar suas respectivas áreas e de fazer "rolês" juntamente. E também, planejam participar de festas, exposições, lançamentos de vídeos, etc. Portanto, a participação em campeonatos pressupõe o ingresso em diferentes redes de relações que são estabelecidas, mantidas e ampliadas a partir dos mesmos.

No entanto, nem todos os skatistas fazem parte de uma crew. Muitos possuem relações mais intensas com uma série de amigos, como em uma crew, mas nem por isso se denominam como tal. Desse modo, é importante frisar que o termo é uma construção coletiva nativa daqueles que vivenciam experiências cotidianas em conjunto.

\subsection{3 - Categoria}

\footnotetext{
129 A partir disso pode-se pensar na formulação de Simmel (1987, 18-19), que nos diz que "à medida que o grupo cresce - numericamente, espacialmente, em significado (...) - na mesma medida, a unidade direta, interna, do grupo se afrouxa e a rigidez da demarcação original contra os outros é amaciada através das relações e conexões mútuas".

130 Não foi possível observar qualquer tipo de rivalidade entre as crews.
} 
Cada etapa do Circuito Sampa Skate é dividida em categorias que variam de acordo com a idade, o sexo e o nível técnico do participante. Portanto, a lógica é que cada um esteja presente no dia correspondente à sua categoria. Na maior parte do tempo as relações se dão entre skatistas que disputam a mesma categoria. Por exemplo: no grupo "amadores", sábado é o dia reservado às categorias "amador II" e "feminino II"; e domingo é reservado às categorias "amador I" e "feminino I". Desse modo, durante a competição, os skatistas do "amador I" tendem a se relacionar com outros dessa categoria; o mesmo é válido para o "amador II" e os respectivos skatistas que fazem parte dela.

Ser de uma mesma categoria supõe que o skatista possua nível técnico e um tempo de trajetória na prática do skate parecido com o do outro. Há várias exceções, mas priorizar relacionamentos com aqueles que estão em uma possível condição de igualdade (de tempo e de técnica do skate) é algo que pôde ser observado entre eles. Em função disso, durante o trabalho de campo, era bem difícil encontrar skatistas de categorias diferentes se relacionando ${ }^{131}$. No entanto, essas relações se dão em função da própria dinâmica e do formato de participação das categorias no Circuito Sampa Skate, conforme apresentado. Fora desse contexto, segundo alguns skatistas, é preciso ter humildade, e por isto não se deve negar o relacionamento com aqueles de categorias diferentes:

\begin{abstract}
A humildade é uma coisa que é demonstrada. É igual skate: skate não é falado. É andado. Não adianta você falar que acerta isso, aquilo. Da mesma forma que as pessoas estão me vendo, eu estou vendo as pessoas. Então eu gosto do "mirim", gosto do "iniciante" (Everton Canuto, entrevista em 26 de março de 2010).
\end{abstract}

\title{
1.5.4 - Dinâmica relacional e situacional
}

Além das formas de sociabilidade apresentadas, de acordo com cada situação, podem vir à tona certos tipos de relação orientados pela geração da pessoa. As competições do grupo "juniores” são voltadas para as seguintes categorias: "estreante-

\footnotetext{
${ }^{131}$ Notei algumas exceções, como esta: as skatistas Jennifer Santos e Mariana Nunes faziam parte da categoria "feminino II". O dia correspondente às suas participações na competição é, de acordo com o cronograma, sempre no sábado. Mas observei a presença dessas skatistas, em algumas etapas, no domingo, interagindo com as garotas da categoria "feminino I". Portanto, neste dia elas foram à competição não para competir, mas para encontrar as amigas e os amigos de outras categorias.
} 
infantil"; "estreante-mirim"; "infantil"; "mirim" e "iniciante". Quase todos os competidores são, ainda, crianças. Logo, a presença dos pais é significativa ${ }^{132}$. O encontro daqueles que se reconhecem como "pais de skatistas" faz com que eles se relacionem ${ }^{133}$, e os leva a criar laços de amizades, trocar favores, combinar de uma família visitar a outra ocasionalmente, compartilhar informações relevantes relacionadas à prática do skate pelos filhos, enfim, ajudar no que for necessário e de interesse mútuo. Para Rogério "Tilskater", pai do skatista Igor Smith, a presença da família em campeonatos amadores é um fato recente:

Se você soubesse o tanto que eu fico contente em ver os pais nos eventos! Que nem no Paulista [Circuito Paulista de Skate]. No Paulista vai praticamente um ônibus, de pais e filhos. O último que foi agora, no Maremoto [campeonato realizado no interior do Estado] foram dois ônibus ${ }^{134}$. A mulher de São José [dos Campos], e o ônibus do pai do Matheus, da TRV Crew, lotado com vários pais. Isto me deixa contente. Antigamente eu vivia sozinho [nos campeonatos]. (...) Mas hoje em dia mudou. Mas isto também é muito por conta da mídia, da televisão, que está mostrando o skate como sucesso. Quanto aos pais e eventos: [eles] trocam emails, trocam informações, querem saber de fotos dos filhos, querem saber sobre os próximos eventos. Eu tenho [o contato com] três mães, toda semana converso com elas. Que nem a mãe da menininha que vai correr aí. Pô, conversei com ela ontem o dia inteiro. Eu falei com ela: "a sua filha anda muito”. (...) Ela é arrojada, ela vai para cima dos obstáculos. (...) E a mãe dela acompanha. A mãe dela vem lá de Artur Nogueira, e está aqui em todos os "Sampas". Gasta muito dinheiro, sem nenhuma premiação (Entrevista em 4 de outubro de 2009).

132 No grupo "amadores" também é possível notar a presença de vários pais, porém, em menor número, se comparado aos "juniores".

133 Entre os pais dos skatistas são criadas redes de relações que ultrapassam os domínios dos campeonatos de skate disputados pelos filhos. Por isso há trocas de informações e encontros regulares entre eles. Um bom exemplo da sociabilidade entre aqueles que se reconhecem como "pais" se dá nas viagens dos skatistas para campeonatos no interior do Estado de São Paulo, em que um pai organiza uma excursão composta, em sua maioria, pelos skatistas e suas respectivas famílias, conforme expresso nas falas de Rogério "Tilskater".

134 A fala desse interlocutor é bastante esclarecedora quanto a alguns aspectos. Com vários campeonatos ocorrendo simultaneamente ao Circuito Sampa Skate - como o Circuito Paulista de Skate e o Circuito Maremoto -, as redes de relações se ampliam para outros contextos, inclusive fora da cidade de São Paulo. Ao participar de distintos campeonatos diversas redes se cruzam, se justapõem, se desfazem e se refazem. 
Na visão desse pai, o apoio da família é fundamental para que o skatista se desenvolva rumo ao profissionalismo, considerado um dos objetivos por aqueles que participam dos campeonatos:

Eu acho fundamental [o apoio da família]. Se o cara elogiar pelo menos uma coisinha daquilo que você quer ter como futuro... Quando o moleque não tem apoio nenhum, aí não rola. Já vi vários aqui. É moleque brigando com o pai; às vezes tendo que dormir na rua para ir ao evento no outro dia... Fora várias meninas que o pai não deixa ir para outras cidades, mesmo acompanhadas de outra mãe (Rogério "Tilskater", entrevista em 4 de outubro de 2009).

Pode-se dizer com base nos dados coletados que este tipo de sociabilidade é marcadamente intrageracional, ou seja, se dá sobretudo entre pessoas com variações de idades parecidas. De um lado estão os pais (adultos) e de outro, os filhos skatistas (crianças e jovens). No caso de uma sociabilidade intrageracional, mais especificadamente entre os skatistas, penso que ocorre uma "agregação em grupos de sua própria idade que criará um conjunto de relações específicas de determinada faixa etária" (Pereira, 2007, 2) ${ }^{135}$.

Após essas considerações, percebe-se a dinâmica das relações que são estabelecidas no Circuito Sampa Skate e também como que a suposta homogeneidade percebida ao entrar em algum ginásio onde ocorre a competição, na verdade, não passa de uma aparência. Destarte, diversos sinais diacríticos orientam formas de sociabilidade entre os skatistas presentes em cada campeonato. Às vezes, a preferência musical, o estilo de roupa usada, a idade ou a categoria disputada podem identificar se os relacionamentos de um skatista se dão em maior parte com aqueles que são portadores de códigos mais específicos. É importante salientar ainda que a constituição de certas aglutinações não é estanque, pelo contrário, pode ser pautada em um ou mais dos aspectos apresentados, que são acumulados: os skatistas podem se reunir, por exemplo, com base somente na categoria; com base em categoria e na localidade; com base na localidade e na preferência musical, enfim, mediante aos diversos tipos de possíveis arranjos.

\footnotetext{
135 É interessante notar que os próprios pais também são influenciados pelos filhos. Nessa relação eles passam a adotar uma série de códigos (como, por exemplo, o cumprimento feito) e até mesmo o estilo de se vestir dos skatistas.
} 
A sociabilidade estabelecida é relacional e situacional na qual, de acordo com o interesse do momento, os skatistas se ligam ou se desligam de suas associações com os outros. Com isso, podem transitar por várias redes que fazem parte do campeonato e que se ampliam a partir dele, o que lhes possibilitam ter contato com aqueles que eles mais se identificam ${ }^{136}$. Deste modo, há uma alternância na identificação: para o exterior, todos se designam como skatistas; no interior dessa identificação, são criadas outras fronteiras imaginárias ${ }^{137}$.

\subsection{5 - "Uma mão lava a outra"}

A partir dos vínculos entre os skatistas são criados atos de reciprocidade, visando uma não separação entre as pessoas envolvidas. Durante o curso da competição, por exemplo, há a realização de várias trocas e favores entre os competidores. Ao chegar à

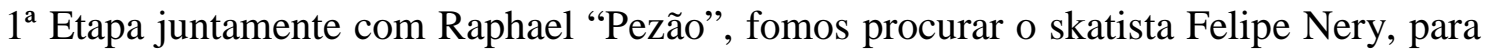
entregar-lhe uma lixa de skate. Após encontrá-lo, dirigimo-nos para a arquibancada. Passados alguns instantes, Felipe Nery surgiu com várias peças de skate nas mãos e sentou-se próximo a nós. Ele colocou-as expostas na arquibancada, a pedido do skatista profissional e juiz Gian Naccarato, para tentar vendê-las a um preço mais barato que nas lojas ${ }^{138}$. Chegada a hora de Felipe competir, ficamos responsáveis pelos pertences. No aquecimento, ele deu o azar de quebrar seu shape. Triste, ficou sem saber o que fazer. Como conseguiria competir? De repente, o skatista Sandro Sobral, também juiz da competição, emprestou seu próprio skate (que tinha um shape igual ao quebrado) para Felipe competir. Após a sua volta, Felipe retornou para as arquibancadas. Logo foi a vez da skatista Euli Vieira ter problemas com seu skate: um rolamento havia estourado. Com isso Felipe se dispôs a ajudá-la, dando-lhe um rolamento novo. Essas são situações bem comuns entre os skatistas, em que uma hora se faz um favor, em outrora, se é ajudado. Ao ir de encontro com essas idéias, Rodrigo "Bocão" afirma que:

\footnotetext{
136 Por meio da conversação (uma modalidade básica da sociabilidade) despida de fins práticos e de um propósito, os skatistas trocam experiência e constroem socialmente sua realidade, em função dos valores comuns àqueles que se denominam como tal, mantendo o vínculo e zelando pela relação estabelecida (Simmel apud Frúgoli Jr., 2007). As suas conversas são efêmeras, mas podem ser (re)estabelecidas a qualquer momento, de acordo com a motivação do próprio skatista na competição.

137 Fora dessa totalidade, todos se identificam como skatistas. Mas durante os campeonatos, são criadas várias categorias nativas de distinção, como algumas já citadas: streeteiros, skatepunks, gangueiros, rastas, etc.

${ }^{138}$ A venda de produtos para skate é uma prática comum em campeonatos, onde os skatistas comercializam tanto produtos novos quanto usados.
} 
O pessoal do skate tem um afeto bem legal, aquela idéia de motoqueiro na rua: um ajudar o outro. As pessoas que se identificam com as idéias, convivendo, se dá bem e acaba adquirindo uma amizade legal. Nesta daí, acabam levando [o outro] para casa para dormir. Se precisar passar fome junto, passa. Se precisar dividir um pão em dois, divide... É isso aí. Uma mão lava a outra, né? (Entrevista em 17 de março de 2010, grifos meus).

Como o circuito é itinerante, há, a partir dessa dinâmica, outros exemplos notáveis de reciprocidade. Quando um campeonato é realizado em uma localidade distante, há a possibilidade de um skatista conhecer algum outro que aí mora e que pode hospedá-lo em sua casa. Da mesma maneira, esse que o acolheu, quando for à cidade ou ao bairro do outro, provavelmente ficará na residência dele também:

Tem gente que já veio para São Paulo, veio para campeonato. Conheci [a pessoa] no campeonato e "pô, eu não tenho onde dormir. Será que tem como ficar lá [na sua casa]?”. É claro, eu hospedo em casa. Às vezes a gente vai viajar, volta pra São Paulo e precisa fazer alguma coisa e nós estamos junto. Às vezes alguém vem: "pô, estou aí em São Paulo. Vamos fazer um 'rolê'?”. Sempre estamos juntos, um acolhendo o outro. (...) Tenho amigos que eu posso contar para me hospedar bem e ser bem recebido (Rodrigo "Bocão", entrevista em 17 de março de 2010).

Além das falas de Rodrigo "Bocão", observei durante o curso do Circuito Sampa Skate que o skatista "Guega" Cervone, competidor da cidade de Cubatão, veio para São Paulo e ficou na casa de Alexandre "Cotinz". Da mesma forma "Cotinz", sempre que vai a Cubatão, fica na casa de seu amigo "Guega". E não é só isso que pressupõe um ato de reciprocidade. A partir do momento em que se disputa uma etapa em outra região que não é a do competidor, seus amigos desta região devem, quando acontecer alguma etapa em sua própria localidade, ir disputá-la, no sentido de retribuir a visita. As retribuições possibilitam o exercício de uma sociabilidade alargada (Agier, 1999) ao skatista ${ }^{139}$, pois a cada etapa disputada, conhecem-se novos skatistas e vivenciam-se outros tipos de situações:

139 O exercício da sociabilidade alargada (Agier, 1999) não se resume às competições de skate e muito menos a um espaço fixo. As redes de relações criadas pelos skatistas interagem com a dinâmica urbana, e participam de várias situações que ocorrem simultaneamente. Por exemplo, pode-se andar de skate na parte do dia com os amigos, e logo após ir para alguns shows na companhia dessas mesmas pessoas. Com 
Comecei andando de skate mais pela região, com os amigos de escola, amigos da rua mesmo. Depois você vai conhecendo mais amigos, amigos, e você começa a viajar... Começa a fazer amigo pelo Brasil inteiro (Rodrigo "Bocão", entrevista em 17 de março de 2010).

É como minha mãe fala: “caramba, se você for para qualquer lugar aí, acho que você tem casa para dormir. Todo mundo vêm e dorme aqui em casa!". Eu tenho amigo do sul, do nordeste, de todas as regiões do Brasil (Rodrigo "Bocão, entrevista em 17 de março de 2010).

Os skatistas vão ao Circuito Sampa Skate para encontrar os pares, conhecer novas pessoas, exercer uma sociabilidade mais densa, atualizar os seus códigos e compartilhar experiências. Além disso, muitos obviamente também vão ali para competir. Após o olhar para a arquibancada, local em que se reúnem os espectadores, o próximo tópico abordará a competição, isto é, o momento em que os skatistas colocam em evidência as técnicas e as representações daquilo que praticam.

\section{6 - Um olhar para a pista de skate}

Devido ao grande número de competidores em cada etapa do Circuito Sampa Skate ${ }^{140}$, a competição tenta seguir um cronograma bem definido, respeitando principalmente o horário; caso contrário, o evento pode se estender ao longo de todo um dia ${ }^{141}$. No começo da tarde, com as inscrições já encerradas, inicia-se a competição através das eliminatórias. Sandro "Testinha" anuncia a lista de competidores (geralmente vinte) que fazem parte da bateria que competirá. Com isso, os skatistas listados seguem para a porta de entrada da pista de skate. Após comprovarem aos seguranças que foram convocados (por meio da pulseirinha), são liberados para o aquecimento da volta, que dura 15 minutos. Essa é uma forma de se reconhecer a pista e

isso, interage-se com diversos atores e instituições, com as mais diversas intenções, desde políticas até religiosas (sobre esportes "radicais" e formas de religiosidade vide Aguiar, 2009). E em cada momento conhecem-se novas pessoas, vivenciam-se novas experiências, aprendem-se novos códigos, realizam-se trocas simbólicas, estabelecem-se mediações. Portanto, ser skatista não implica em engessar as atividades de uma pessoa somente ao universo do skate, visto que suas práticas são situacionais e relacionais. Durante esta pesquisa, é possível notar exemplos dos "rolês" realizados pelos skatistas na cidade e os diversos arranjos feitos em suas associações e relacionamentos com os outros.

140 De acordo com dados da organização do evento, o número total de competidores (considerando todas as categorias) ao longo do Circuito Sampa Skate 2009 foi de exatamente 600 skatistas.

141 Quase todas as etapas do Circuito Sampa Skate terminam durante o período da noite. 
de se acostumar com seus obstáculos. Como em cada etapa, na maioria das vezes, há obstáculos diferentes, é importante andar neles antes da competição, já que cada um exige um grau diferente de dificuldade e técnica.

Diversos skatistas ocupam a pista ao mesmo tempo. Assim que entram, correm para algum obstáculo, pois como o aquecimento é curto, é fundamental aproveitar o tempo para treinar, pelo menos naquele momento, as possíveis manobras que serão realizadas na hora da volta. A pista pode ser dividida em dois lados, tendo como referência a fun box em cada um deles. Os skatistas transitam entre esses lados, tentando andar um pouco em cada obstáculo. Durante o aquecimento é preciso ficar atento para os códigos que estão em voga na situação. Com poucos obstáculos para muitos skatistas, é importante estabelecer certa ordem para que todos possam andar sem prejudicar um ao outro. O participante manda sua sequiência de manobras nos obstáculos e somente pára no momento em que erra ou quando alguém o atrapalha. Dentre os percursos mais utilizados estão: dropar (descer) a rampa reta; saltar a transição da fun box; ir em direção a outra rampa reta e mandar uma manobra naquele local; e retornar para a fun box para deslizar em algum dos obstáculos (corrimão ou caixote). Entretanto, não existe nenhum tipo de regra que estabeleça que o skatista deva seguir essa ordem ${ }^{142}$, pois o mesmo teria a princípio a livre escolha para fazer o que lhe bem entender nos obstáculos.

Após mandar sua manobra ou seqüência de manobras, o skatista deve sair rapidamente dos obstáculos, deixando-os livres para os outros. É tudo questão de segundos, visto que qualquer demora pode ocasionar choques entre eles, o que muitas vezes resulta em machucados para os envolvidos ${ }^{143}$. Indiretamente estabelece-se um consenso em relação à oportunidade de cada competidor ir aos obstáculos. Ir na vez do outro é um desrespeito aos códigos, o que pode causar reclamações ao "furão": ele é visto como o "fominha", aquele que "tesoura" os outros e que só pensa nele. Dentro da pista, os skatistas não imaginam outra coisa a não ser andar de skate. Afinal, aqueles

${ }_{142}$ Esse percurso citado, com base nas observações, foi o mais regular entre os competidores.

$143 \mathrm{Na} 2^{\mathrm{a}}$ Etapa, um skatista teve o azar de bater o skate em sua boca. Sangrando muito, o competidor deveria ser atendido às pressas pelos enfermeiros. No entanto, justamente no momento do acontecimento, os profissionais não estavam presentes, pois tinham saído para lanchar. Alguns seguranças tiveram que ajudar o skatista machucado que, felizmente, não sofreu nada grave, sendo liberado para andar de skate novamente. Um segurança, aproveitando-se da ausência do enfermeiro, disse-me angustiado que: "foi só o cara sair que o skatista machuca. Está vendo como são as coisas? Imagine se o skatista tivesse machucado mais sério?". Nessa mesma etapa, após o ocorrido, a skatista Mônica me mostrou uma série de hematomas em várias partes de seu corpo: machucados nas pernas, roxos e uma marca de corte no rosto. Cada marca possuía uma história. Com isso, ela contava-me - de uma forma um tanto orgulhosa sobre os diversos tombos sofridos, mas que nem por isso, tinha vontade de parar de praticar o skate. 
breves minutos são os mais esperados para se colocar em prática uma parte daquilo que sabem fazer em cima do "carrinho".

Em competições amadoras, como o Circuito Sampa Skate, não há tanta preocupação por parte dos skatistas em realizar um preparo físico, fazer outro tipo de atividade para melhorar o rendimento do corpo, adotar um tipo de dieta, ou comprar algum tipo de roupa que possibilite uma melhor flexibilidade. Essas características, que seriam aplicadas a qualquer atleta de outro tipo de esporte, não condizem com a maior parte dos skatistas. É raro vê-los fazendo alongamento antes da competição. Alguns confessam ter vergonha de tal exercício, enquanto outros preferem não "bancar o atleta" ${ }^{144}$. Eles colocam o skate no pé e dão impulsos de um lado para outro por entre os obstáculos, até o momento em que ficam "quentes":

$\mathrm{Na}$ real... Eu gosto de dar uma volta na pista antes, porque tem os buracos. Costuma ter uns buracos. E com isto, ver o que dá para fazer em cada lugar. E tento bolar alguma coisa na cabeça, só que o skate para mim, tem aquele lance de surpresa, né? Pô, dei uma manobra ali, então dá para me dar outra (Alexandre "Nicolau", entrevista em 26 de março de 2010).

Com o corpo aquecido, eles começam a arriscar as primeiras manobras, geralmente as mais básicas, até o momento em que se sentem seguros para aquelas mais técnicas. As manobras difíceis, que exigem maior grau de dificuldade e de coragem (e conseqüentemente envolvem maiores riscos de tombos), quando acertadas por um skatista, são aplaudidas pelos outros competidores que estão em volta da pista. Alguns, inclusive, vão saudá-lo pessoalmente, parabenizando-o pelo acerto.

Pelas manobras no aquecimento, revela-se o nível de competitividade do campeonato. Se todos estiverem acertando constantemente boas manobras, tudo indica que a competição será, segundo os skatistas, "cabreira”. Durante esse tempo, também é necessário tomar alguns cuidados para não se machucar, ou então, para não quebrar alguma peça do skate. Antes do aquecimento, os skatistas mentalizam as possíveis manobras que, dentre o leque de possibilidades, vão mandar em suas respectivas voltas.

\footnotetext{
${ }^{144}$ Ser ou não é ser "atleta" é algo ambíguo entre os skatistas. Alguns acreditam veementemente que são atletas. Perguntei sobre isso a Everton Canuto. Ele então me disse: "tenho certeza". Fiz a mesma pergunta a Rodrigo Bocão, que me respondeu da seguinte forma: "eu sou skatista. Ando skate". Além disso, durante diversas conversas realizadas no trabalho de campo no Circuito Sampa Skate, em um mesmo discurso alguns skatistas referiam-se aos praticantes do skate como "atletas", mas quando perguntados se se consideravam como tais, mudavam o discurso e diziam que não, pois "skatista não é atleta, skatista é skatista".
} 
Chegam à pista com um objetivo bem definido daquilo que pretendem fazer. Caso alguma das manobras não esteja "saindo", optam por outras. Comumente, as mais acertadas no aquecimento são aquelas mandadas na competição. Mas pode haver surpresas: alguns skatistas, durante o aquecimento tentam algumas manobras, e na hora da volta mandam outras. Há ainda aqueles que passam quase todo o aquecimento errando manobras, mas no momento da competição, conseguem acertá-las. E há também, o contrário: aqueles que acertam todas no aquecimento e erram todas na apresentação.

O skatista é, em geral, seu próprio agente. Nas competições de skate não há técnicos, instrutores ou papéis do tipo. É o competidor quem decide o que deve ou não fazer. Aqueles que se envolvem mais efetivamente com ele, dando-lhe dicas ou cobrando certa postura, como alguns pais, constroem um tipo de conduta que não é bem vista pelos demais, sendo alvo de críticas em alguns momentos. Nas etapas em que presenciei, eventualmente, apareciam pais que tentavam se passar por técnicos, gritando da arquibancada com o filho para fazer um tipo de manobra ou para utilizar um dos obstáculos. Muitas vezes, até adotavam uma postura agressiva e impaciente com os erros cometidos pelos filhos. Longe desses pais, os skatistas zombavam ironicamente de suas atitudes, falando, tal como ouvi de um competidor, que "se o skatista não acertar a linha e não ganhar o campeonato, é capaz do pai dele matar ele". A representação socialmente aceita vinculada ao papel dos pais é de apoiadores do skatista, não devendo cobrar explicitamente, nem gritar com o filho durante o aquecimento ou a volta, como se fosse um técnico de futebol agindo com os jogadores que estão dentro de campo. Rogério "Tilskater" conta que, com o tempo, deixou de lado a postura de cobrança, passando a incentivar Igor Smith, seu filho, de outra forma:

No começo eu era até meio chato. Eu enxergava o moleque, via aquilo [a cobrança explícita] como exemplo e achava que era aquilo que tinha que fazer. Hoje não. Hoje eu acho assim: ele tem potencial. Eu vejo ele andando numa pista mandando umas "putas" manobras "cabreiras", e chega no campeonato e o cara só faz o básico, só para passar. Então eu chego e dou uns toques. Não igual a certos pais. Nunca vou chegar, brigar, como já vi pai de skatista bater nele. Eu nunca vou fazer este tipo de coisa. E nunca vou dar uma bronca no meio de todo mundo (Entrevista em 4 de outubro de 2009). 
Após 15 minutos de aquecimento, Sandro “Testinha” retorna ao seu posto, pega o microfone, e anuncia o fim do tempo. Nesse instante, alguns seguranças entram na pista para tirar todos os skatistas do local ${ }^{145}$. Sempre há aqueles que desviam dos mesmos, para poder andar alguns segundos a mais, mas "Testinha" os adverte publicamente, cogitando a possibilidade de, caso venham fazer aquilo novamente, serem desclassificados. Cada competidor possui 1 minuto para fazer sua volta na pista. $\mathrm{O}$ objetivo é mandar manobras nos diversos obstáculos e, conseqüentemente, ser julgado pelos três juízes da competição, que atribuem suas notas secretamente. Não há um critério bem definido de avaliação, visto que uma manobra só pode ser julgada em relação a outra. Desse modo, o que conta são as preferências dos próprios juízes, que julgam subjetivamente cada uma delas. Portanto, aqueles que discordam das notas tendem a achar que a competição está sendo "roubada".

"Testinha" convoca um competidor por vez, que deve ficar sozinho na pista para apresentar suas manobras. Ele pode começar a volta por qualquer obstáculo, ficando ao seu critério decidir quais deles utilizar. Com tudo pronto, o locutor anuncia: "quando dropar, está valendo!”. A partir do momento em que o skatista desce de alguma rampa ou quando dá um impulso no skate, os segundos passam a ser cronometrados. Antes de fazer a volta, muitos adotam uma série de pequenos ritos: fazem o sinal da cruz; batem o calcanhar nas rodas ou a mão na lixa do skate; respiram fundo. Esse breve minuto parece durar uma eternidade. Há um momento de tensão para o competidor, pois nesse tempo ele é posto à prova diante de um ginásio lotado de outros skatistas. Sob vários olhares, está sujeito tanto ao fracasso quanto ao sucesso. Muitos fracassam porque ficam nervosos, com "frio na barriga", e não conseguem se concentrar nas manobras. Contudo, conforme o tempo de prática de skate, passa-se a disputar tantos campeonatos até um momento em que a competição é encarada com mais tranqüilidade.

Ao entrar na pista supõe-se que o skatista corresponda a certas expectativas ${ }^{146}$, relacionadas ao seu desempenho no momento em que anda de skate. Com base nisso,

\footnotetext{
145 Em uma etapa do grupo "juniores", o skatista profissional Paulinho "Barata" (que também é pai de um skatista competidor) andava de skate na pista. Em certo momento veio um segurança e solicitou-lhe para que saísse da pista. Questionei a Raphael "Pezão" o porquê disso, visto que geralmente os skatistas profissionais podem andar na pista sem restrições. Ele então me disse que Paulinho "Barata" estava ali não como skatista profissional, mas como um pai de skatista competidor, e que por isso não podia andar de skate.

${ }^{146}$ Para participar de um campeonato, espera-se que o praticante tenha, ao menos, alguma competência técnica capaz de saber utilizar os obstáculos da pista. Somente nas categorias do grupo "juniores", compostas por aqueles envolvidos com a prática do skate há pouco tempo, é mais aceitável a presença dos inexperientes.
} 
para participar de um campeonato não basta somente saber dar impulsos e ficar equilibrado em cima do skate: "subir em cima do skate qualquer um sobe, quero ver é encarar o obstáculo", disse um skatista. As competições são exaltações tanto coletivas quanto individuais, onde o competidor tem de provar não só para os outros, mas também para si mesmo, que é capaz de superar os desafios de cada obstáculo e os limites de seu corpo e de sua mente, para conseguir o objetivo de acertar a tão esperada manobra.

A volta do skatista é vista atentamente pelos espectadores na arquibancada que, para motivá-lo, batem palmas a cada manobra acertada. Caso a manobra seja reconhecida pelos outros como difícil, há uma agitação ainda maior, quando então vários deles gritam, assobiam ou batem o skate na arquibancada. Aliás, bater o skate na madeira ou em uma grade é algo marcante em qualquer campeonato de skate, o que contribui para deixar a competição ainda mais efervescente. Durante a volta, cessam as conversas paralelas e todo o público possui um mesmo foco. As atenções e as falas são voltadas para uma mesma situação, constituindo um tipo de interação focada, onde "os diferentes participantes estão em co-presença imediata, compartilhando um alinhamento coletivo a uma mesma situação" (Goffman, 1963 apud Gastaldo, 2005, 114).

Os skatistas no Circuito Sampa Skate, como pode ser visto ao longo do texto, são, ao mesmo tempo, competidores e espectadores da competição. Destarte, a maioria é detentora de um "olhar treinado" para todos os acontecimentos dentro da pista, reconhecendo a intencionalidade de cada movimento, das técnicas corporais, dos tombos e dos riscos, o que produz, "do ponto de vista de quem vê, algum significado para fruir com aqueles que estão em performance" (Toledo, 2009, 13). É importante compreender para ser compreendido: ora um executa uma manobra e o outro a contempla; ora o outro executa uma manobra e é contemplado pelos demais ${ }^{147}$. No caso do skate, "ver e jogar [ou neste caso, andar de skate] participam de uma mesma dinâmica" (Toledo, 2009, 13).

A força, característica essencial em diversos tipos de competições esportivas, no skate perde parte de seu valor. Valoriza-se muito mais a leveza e a flexibilidade nos gestos e manobras que compõem o estilo pessoal de cada skatista. Aliás, aqueles skatistas "duros", como eles mesmos dizem, ou seja, aqueles que não possuem tanta flexibilidade e equilíbrio, são dotados de um estilo desprezado pelos demais, pois para

\footnotetext{
147 A expressão da compreensão das manobras se dá por meio, principalmente, de gritos como "Yeah" ou
} "Uôu". 
andar de skate de forma "estilosa", o "cara tem que ser leve" ${ }^{148}$, disse-me Raphael "Pezão". Portanto, estilo e técnica devem estar lado a lado. Se um skatista não souber articular essas características, ele pode ser motivo de chacota para os outros. A partir do trabalho de campo, observei dois exemplos: o do skatista que tenta "marcar naipe" e o do skatista "robozinho".

O skatista que tenta "marcar naipe" é aquele que anda com roupas de acordo com os códigos e com os símbolos mais valorizados pelos outros, que se enturma com todos, que demonstra ser possuidor de um estilo singular, e que tenta passar a imagem de um bom skatista. Porém, após criar todas essas expectativas, ao entrar na pista, "não representa". Durante a 4 ${ }^{a}$ Etapa, sentei-me ao lado de Raphael "Pezão" para assistir à competição. Em vários momentos ele zombava desses skatistas, os quais eram "tirados" e tentavam "forçar algo que eles não eram dentro da pista", ou seja, "marcavam naipe". Esses skatistas apresentam uma concepção idealizada de um tipo de situação ao tentarem passar uma falsa impressão de si aos outros.

Por outro lado, as técnicas corporais mais aceitas pelo público nem sempre são aquelas que produzem os resultados mais eficazes ao longo de toda a volta. Os skatistas "campeonateiros" quase não erram nenhum tipo de manobra, estão sempre entre os melhores da competição, adotam sucessivas estratégias para vencer, e por isso, são geralmente categorizados como "robozinhos":

[O campeonato] está muito nível. Os caras que andam de skate parecem uns "robozinhos", que não erram nenhuma manobra. E este não é o meu estilo de skate. E não ficar ali só 1 minuto fazendo uma linha, que chegou acabou e pegou a premiação. Não é para competir e ficar em primeiro, segundo ou terceiro lugar. Não é só isso ("Gui" Martins, entrevista em 24 de março de 2010).

Às vezes manobra técnica, fica muito robótica, que nem nos moleques novos que estão criando uma característica... Eles acham que tudo tem que entrar rodando, tem que sair rodando. Isto perde o estilo, a velocidade. Acaba mandando uma manobra de eixo, escorrega um palmo de eixo. (Alexandre "Nicolau", entrevista em 26 de março de 2010).

\footnotetext{
148 É a leveza que possibilita ao skatista "voar", ou seja, mandar uma manobra alta entre um obstáculo e outro, ou então deslizar em alguma borda ou corrimão da pista de skate.
} 
Dominar a técnica e os movimentos corporais, realizar certos gestos, ter equilíbrio e fluidez são condições essenciais para a produção de uma manobra "estilosa", ou seja, uma manobra "bonita de se ver". Além da técnica e do estilo, outros elementos também interagem com a volta do praticante, como a utilização do maior número de obstáculos, seu estilo de se vestir e a música escolhida. Quanto mais ágil, criativo e seguro for, mais confiança o skatista passará aos juízes ${ }^{149}$.

A partir do momento em que se anda de skate, utiliza-se "muito mais o uso dos reflexos do que da reflexão" (Brandão, 2009, 11). A reflexão se dará no momento em que o skatista não estiver em ação. Nessa dinâmica, ao observar os outros competidores, ele interpreta, produz investimentos e calcula o que deve ser feito no momento em que for posto à prova, ou seja, na hora de sua volta. Prova disso é que, durante as etapas do circuito, foi possível ver aqueles mais competitivos e centrados na competição em si, observando atentamente todos os possíveis "concorrentes" e traçando estratégias para superá-los.

O skatista Alexandre "Nicolau", participante da categoria "amador I", considera que os competidores com nível técnico elevado tendem a se dar melhor no campeonato. Mas para ele não adianta muito ter essa característica sem saber utilizar a pista de skate como um todo, fazendo uma linha, ou seja, uma seqüência de manobras ininterruptas, na competição:

Os juízes acabam dando valor [às manobras técnicas] sim. O moleque acerta só manobra difícil no campeonato e não erra. Só que eu acho assim: se é um campeonato, ele tem os critérios, tem as regras. Não é só porque que ele está mandando várias manobras técnicas... De repente ele está mandando estas manobras técnicas num lugar só. Não usou mais da metade da pista que ele tem para usar. Então acho que eu sendo juiz, eu contaria isto (Entrevista em 26 de março de 2010).

É uma coisa que eu vejo nos moleques hoje em dia (...). É muito skate na mão. [Antes] se o cara colocasse o skate na mão, perdia pontos, por mais que desse uma volta legal. O cara tinha que ter linha. No máximo de duas em duas manobras, para você conseguir uma pontuação boa. Porque tem as regras... Grau de dificuldade, velocidade, utilização de obstáculos. E linha, né? Campeonato é linha, e não só skate na mão. Se não acaba ficando feio,

149 Durante o minuto dentro da pista, caso o skatista busque vencer a competição, ele terá que ser eficiente. Por isto que ter a base, ou seja, acertar constantemente as manobras em diferentes obstáculos, é um diferencial dos bons skatistas 
parece um pouco de ping-pong. É elemento surpresa: deu uma manobra e já vai mandar outra. Já ouvi moleque falar: "vou mandar um ollie 180? Não, é feio. Vou dar um ollie no campeonato? É feio". Você sabendo por um ollie na linha, ele fica bonito. E ele vai te ajudar a fazer outra manobra. Tem que saber... Aí eu acredito que é com experiência mesmo. Ele vai mostrando isso para a molecada (Entrevista em 26 de março de 2010).

Além dos skatistas mais focados na competição, também há aqueles mais despreocupados, que entram na pista sem tantas cobranças e expectativas em demonstrar um bom desempenho. Buscam, em vez da eficácia, um tipo de excitação nem tanto pelo acerto das manobras, mas somente pelo fato de andar de skate espontaneamente ${ }^{150}$. Para estes, a competição não é contra os outros, mas contra si próprio. É uma busca de superação individual, pois qualquer nova manobra diferente já é motivo de alegria. O que vale não é o conjunto da volta, mas sim manobras isoladas, alguma que, acertada com técnica e com estilo, permaneça sempre na lembrança tanto daquele que acertou quanto dos que a viram:

Não precisa nem acertar uma volta inteira. Acertar uma manobra da hora que valeu a pena de ver é a maior felicidade para o cara. Às vezes ele está no campeonato, errou a volta inteira, mas acertou uma manobra que não acertava, e acertou ali naquela volta. Ele fica maior satisfeito, mesmo não tendo conseguido passar para uma final, é tipo uma satisfação. Uma superação. Todos os amigos apoiando um ao outro, torcendo para acertar. Se errar, "dá hora, valeu!" (Rodrigo "Bocão", entrevista em 17 de março de 2010).

Para alguns competidores, conforme conversas realizadas, os campeonatos de skate, através do formato com voltas de 1 minuto não revelam quem são, de fato, os melhores skatistas. Sendo assim, a competição por vezes também constitui uma dinâmica situacional, ou seja, o que está em jogo é o melhor skatista do momento, daquela situação ${ }^{151}$. Às vezes o competidor tido como favorito erra todas as manobras e não obtém boas classificações, ao passo que outro, sem saber tantas manobras, pode

\footnotetext{
150 Portanto, há várias perspectivas para os skatistas: para uns o desempenho na competição é central; para outros, não.

151 Em função desse formato, alguns skatistas me disseram que até disputam as competições, mas não dão tanto valor a elas. A prática do skate nas ruas será abordada de forma mais detida no próximo capítulo.
} 
surpreender com base naquilo que domina, acertando tudo na volta e conseguindo ficar entre os melhores.

A partir do momento em que um skatista começa a sua volta, Sandro "Testinha" passa a narrar todos os seus movimentos, dizendo o nome de cada manobra. Além de coordenar a ordem, o tempo e as músicas tocadas na competição, é ele quem agita o evento. Para isso, não basta ser somente um profundo conhecedor do universo do street skate. É preciso ter carisma, ser extrovertido, interagir com competidor, a fim de deixálo mais calmo. "Testinha" costuma dar conselhos, sugerir manobras e alertar sobre quanto tempo falta para acabar a volta. Por meio do microfone ele fica em constante contato com o público, dizendo coisas engraçadas capazes de arrancar risadas de todos. No decorrer da $6^{\mathbf{a}}$ etapa, o locutor zombou por diversas vezes daqueles skatistas que faziam a inscrição, mas que, quando chegada a hora de participar, desistiam: "não vai correr, por quê? Você é mulherzinha? Você é bichinha? Tá dodói? Machucou o pezinho?". Após ironizar publicamente o skatista, ele pedia desculpas pelas brincadeiras, e dizia ao público para considerar que o competidor ausente era "muito macho". Enquanto acontece o campeonato de skate, "Testinha" torna-se uma espécie de "placar" das competições de futebol que ocorrem simultaneamente, fornecendo os resultados dos principais jogos dos times da capital. Além disso, também acolhe e deixa as famílias bem à vontade no evento. Recordo da vez em que, na $1^{\text {a }}$ Etapa, o locutor mandava um grande abraço para a Dona Maria, avó da skatista Jennifer Santos, que prestigiava o evento, e pedia à galera que a respeitasse.

Após a volta, o skatista deve retirar-se daquele local. Essa é uma das regras do Circuito Sampa Skate: o competidor só fica dentro da pista durante o aquecimento e durante sua volta. No trajeto até a arquibancada, muitos skatistas cumprimentam quem acabou de correr, elogiando suas manobras acertadas ou consolando-o pelos erros. À medida que os competidores de cada bateria correm, eles automaticamente saem da pista, até não sobrar mais nenhum ${ }^{152}$. Terminada uma bateria, Sandro "Testinha" anuncia a próxima e convoca mais alguns skatistas para o aquecimento. Ao término de todas as baterias são finalizadas as eliminatórias. Os resultados não demoram muito para sair. Caso seja necessário, em seguida, ocorre a semifinal e na seqüência, a final.

A parte mais animada de cada dia de competição são as finais das categorias. Esse é o momento em que os dez melhores competidores entram em cena. As regras da final

\footnotetext{
152 Alguns skatistas que não se saem tão bem na competição optam por voltar para casa. Mas a maioria
} ainda permanece no evento, somente para estar na companhia dos amigos. 
são diferentes da eliminatória e da semifinal: nessa ocasião os skatistas possuem, além do aquecimento de 15 minutos, a oportunidade de dar duas voltas de 1 minuto na pista. A melhor nota dessas duas voltas é a válida na pontuação final. Os juízes, que antes davam suas notas secretamente, na final adotam as notas abertas como critério e ao término da volta do competidor, mostram uma placa com a avaliação feita, demonstrando certa transparência no resultado.

Durante a final, os competidores quase não erram as manobras. É preciso planejar uma volta antes de entrar na pista, sem deixar de cogitar a possibilidade de erros. Portanto, a imprevisibilidade nas manobras é algo trabalhado, pois cada volta, por mais que seja pensada, pode sofrer alteração durante seu curso. Os próprios skatistas conhecem bem seu nível técnico. Cientes de suas limitações, entram na pista concentrados naquilo que pretendem fazer. São várias as estratégias utilizadas. Alguns mantêm a mesma volta que fizeram nas eliminatórias; outros preferem inovar, fazendo uma volta completamente diferente. Há aqueles que preferem mandar manobras mais básicas, no intuito de acertar toda a volta. Mas também há aqueles que vão para o "tudo ou nada", tentando somente manobras difíceis de acertar que, quando bem sucedidas, poderão levá-los a vencer a competição.

Cada manobra acertada propicia uma comemoração dos eufóricos espectadores. Ao contrário de outros tipos de competições, onde geralmente se torce para uma ou outra equipe (tal como no futebol) ou para um ou outro competidor (tal como no tênis), no skate basicamente se torce não para a pessoa em si, mas para que qualquer um dos competidores acerte boas manobras. O que os espectadores querem ver é um bom nível técnico, manobras "estilosas" e arriscadas, independente do skatista que as realizem ${ }^{153}$.

Um dos discursos mais recorrentes é que nos campeonatos não há rivalidade entre os competidores. A partir do momento em que se reconhecem como skatistas, todos torcem por todos:

\footnotetext{
Rivalidade entre amigos assim, não tenho não, cara. Fico amarradão quando vejo os caras acertando a linha deles, e me dá até empolgação de acertar minhas coisas. Eu quero ver todo mundo acertar e os juízes suarem a camisa para tentar julgar. Eu acho legal todo mundo andar bem. Acredito que o
}

\footnotetext{
153 Geralmente cada competidor, que também é espectador, mantém uma preferência e atenção para aqueles que são seus amigos. Mas mesmo se um desconhecido estiver competindo, caso ele tenha um bom desempenho, é aplaudido e reverenciado.
} 
campeonato fica mais bonito de se ver (Alexandre "Nicolau", entrevista em 26 de março de 2010).

Na real nunca tem rivalidade. Às vezes seu amigo andou pra caralho e você falou: "nossa, da hora!”. E você se sente feliz por outro skatista estar acertando as coisas. Não só por você. Você sente feliz pelo amigo seu se dando bem em campeonato (Rodrigo "Bocão", entrevista em 17 de março de 2010).

Em uma das etapas, o skatista "Guega" Cervone fazia sua volta. Após uma série de erros, conseguiu acertar uma manobra, que tentava há algum tempo. Alexandre "Cotinz", amigo desse skatista, estava sentado ao meu lado, e após ver a sua conclusão, disse em voz alta, olhando para a pista: "acertamos!". Mesmo sendo rival de "Guega" na competição, "Cotinz" demonstrou satisfação em ver seu amigo acertando uma manobra, de tal modo que o acerto, embora fosse fruto do esforço de um único skatista, adquiriu uma dimensão coletiva, a partir do instante em que se deixou de lado, de certo modo, a competitividade.

As próprias revistas especializadas reconhecem esse caráter dos campeonatos de skate, em que competição e diversão estão relacionadas:

Eles estavam lá para competir e tentar o melhor de si, mas também estavam lá para se divertir, para reencontrar velhos amigos, conhecer novos, para respirar e sentir o clima de um campeonato de skate (Revista CemporcentoSkate, edição 56, 2002).

Porém, por mais que tais discursos sejam recorrentes, na prática, observei também indícios de uma rivalidade instaurada entre skatistas. Preocupados com o ranking e com os respectivos benefícios que podem a partir daí ser obtidos, percebi alguns competidores comentando ironicamente ou desejando que outros (principalmente os melhores da competição) errassem as manobras. No entanto, tudo é feito de forma bem discreta. Mas em uma determinada etapa, a disputa veio à tona com mais visibilidade ${ }^{154}$. Já no final de um campeonato realizado no Clube Tietê, eu estava sentado do lado de fora do ginásio, conversando com a skatista Mônica Torres. Na ocasião, ela me contava

154 No entanto, saliento que foram poucos os momentos em que observei tais indícios de rivalidade. Minha intenção em apresentar esse fato é no sentido de evidenciar que campeonatos de skate são competitivos, embora a solidariedade seja mais evidente em diversos momentos, tanto na pista quanto na arquibancada. 
um pouco mais sobre sua trajetória no skate. Em meio à conversa, passamos a discutir o formato das disputas e ela ressaltava que não havia tanta rivalidade. De repente, veio até nós Jennifer Santos. Ela nos disse que houve uma confusão entre as garotas participantes da categoria "feminino II". Uma competidora, que no ano anterior havia corrido como "feminino I", na edição de 2009 participou como "feminino II", ganhando a competição. Sendo assim, na hierarquia das categorias, ela passou de um nível mais alto para um mais baixo, o que não é permitido de acordo com o regulamento. Os organizadores do evento não perceberam essa atitude e divulgaram sua vitória. Todavia, rapidamente outras competidoras reuniram-se e foram até eles questionar tal acontecimento ${ }^{155}$. No intuito de seguir às regras, a skatista foi desclassificada e sua vitória suspensa. Com isso, estabeleceu-se um clima de tensão entre as garotas, com intenso bate-boca, choros, acusações e desentendimentos. Após os acontecimentos, conversei novamente com várias envolvidas, que me diziam existir rivalidade, "mas só dentro da pista. Fora é todo mundo amigo", concluiu Jennifer.

Terminada a final, após um breve momento acontece a premiação. "Testinha" convida os finalistas a entrarem na pista e a ficarem no centro, uns do lado dos outros. Ele então começa a comunicar os resultados, do décimo colocado para o primeiro. Na hora de premiar os três melhores, faz um grande mistério. Após alguns segundos, é revelado o nome do grande campeão. Os finalistas cumprimentam-se, abraçam-se, e comemoram o feito. Enquanto isso, os membros da organização premiam-lhes com troféus e medalhas, e também com a camiseta do circuito ${ }^{156}$. O fotógrafo da competição permanece atento a todos os momentos, tirando fotos para colocá-las no site da Skate Contest.

Em algumas etapas, foi possível ver ainda um acontecimento um tanto curioso. Vários outros finalistas e competidores correram atrás do campeão de uma categoria para aplicar-lhe a típica comemoração realizada entre skatistas em campeonatos: o “cuecão" ${ }^{157}$. A intenção de muitos skatistas é pegar o campeão para rasgar-lhe a cueca, jogada para cima, em meio ao ginásio. É uma situação um tanto quanto cômica. Após a

\footnotetext{
155 As participantes sentiram-se injustiçadas com tal fato, pois todas estavam atentas com suas pontuações no ranking, visando obter o direito a pleitear a Bolsa Atleta.

${ }^{156}$ Em algumas etapas, observei skatistas usando essas camisetas ganhadas durante a premiação. Usá-las propicia prestígio, visto que somente os finalistas de cada etapa as possuem.

157 Esse tipo de comemoração acontece somente entre os homens. Contudo, em uma etapa, alguns skatistas cogitaram a possibilidade de dar um "calcinhão" em uma garota que tinha ganhado a categoria "feminino II", fato que não se concretizou.
} 
entrega da premiação e ao final de mais um dia de competição, "Testinha" agradece a todos os presentes por participarem do "circuito mais democrático do Brasil".

\section{7 - O útil e o agradável}

Campeonatos que contam com o apoio do poder público - como o Circuito Sampa Skate - são formatados para a disciplinarização da prática do skate. Por implicarem o cumprimento de regras pré-estabelecidas, supõe-se que esses eventos reservem pouco espaço para a criatividade e o prazer que a prática propicia. Afinal, apenas 1 minuto em cima do "carrinho" durante a competição não possibilita, até certo ponto, realizar tantas manobras, muito menos mostrar a competência, de fato, que o skatista possui. $\mathrm{O}$ principal, nesse caso, é a eficácia. Para alcançá-la é preciso adotar estratégias que visem, sobretudo, fazer as manobras com perfeição. Qualquer erro, devido ao grande número de competidores, pode ser crucial nas competições.

Contudo, ao participarem do Circuito Sampa Skate, os skatistas ressignificam as intenções iniciais propostas pelos organizadores, fazendo dos eventos muito mais que uma simples competição esportiva. Por isso não é raro ouvir frases como: "o 'Sampa' é uma festa" ${ }^{158}$. Ainda que os participantes levem a sério a competição, boa parte daqueles que ali estão prioriza e cria discursos em torno do caráter lúdico que as disputas e as diversas formas de sociabilidade propiciam ${ }^{159}$. Tanto que alguns skatistas subvertem o caráter competitivo formatado pelos organizadores e entram na pista para zombar ${ }^{160}$, para demonstrar um tipo de desempenho que não é compatível com a performance esperada pelos espectadores.

Por mais que os campeonatos envolvam aspectos utilitários em suas realizações, são neles que os skatistas também podem romper com a rotina de seus cotidianos, deixando de lado, momentaneamente, o mundo do trabalho, da escola, e das demais obrigações a que estão sujeitos. Mas também há aqueles que tentam estabelecer uma

\footnotetext{
158 Diante desse clima festivo "teríamos então uma ruptura simbólica e performática com a dimensão temporal propriamente dita, no que segue, ao menos, a da vida ordinária” (Toledo, 2007, 263). Faço essa afirmação em relação ao caráter festivo do circuito, com base nos discursos dos próprios interlocutores, sejam eles skatistas, envolvidos com a organização, entre outros, que sempre evocam o termo "festa". 159 Desse modo, a competição possibilita muito mais uma integração que conflitos, divergências e hostilidades. No entanto, novamente ressalto que isto não extingue a competitividade que há entre eles.

160 Prova disso é que em uma etapa, entre tantos fatos engraçados, observei um skatista competindo com um nariz de palhaço e mandando manobras diferenciadas em relação às que eram feitas regularmente pelos outros.
} 
ponte entre o lazer e o trabalho ${ }^{161}$, entre o descompromisso e o compromisso, entre o lúdico e o utilitário. É a junção "do útil e do agradável” que faz com que o skate possa ser visto como uma espécie de transição entre diferentes mundos ${ }^{162}$, mediante as intenções e os objetivos de cada um dos skatistas:

Eu sempre corri [campeonatos] por causa de amigos, todo mundo ir, e falar: "todo mundo anda junto, vamos ir e correr". E foi pela diversão em si, de andar com os amigos em campeonatos. Lógico que todo mundo quer ganhar o prêmio, ser o primeiro lugar. Mas eu sempre vi campeonato como uma festa, um evento onde a gente vai para andar de skate e se divertir. Nem sempre você lembra do cara que ganhou, mas você lembra daquele cara que deu aquela manobra. Sempre corri para me divertir (Alexandre "Nicolau", entrevista em 26 de março de 2010, grifos meus).

Fui participando [do Circuito Sampa Skate] e acabei até me empenhando, para falar a verdade. Para ficar entre os primeiros, para conseguir a Bolsa Atleta. Unir o útil ao agradável, ganhar um dinheirinho aí se divertindo (Alexandre "Nicolau", entrevista em 26 de março de 2010, grifos meus).

As falas de Alexandre "Nicolau" resumem bem os aspectos apresentados. Como vimos, os skatistas possuem um ou vários tipos de motivações no momento em que participam dos campeonatos. Lá expressam diferentes tipos de corporalidades, de preferências, de gostos, entre outras distinções, que orientam também as formas de sociabilidade tecidas e alargadas a partir de cada etapa.

A heterogeneidade constitutiva do Circuito Sampa Skate possibilita aos skatistas estarem "todos juntos e misturados" ${ }^{163}$. Essa frase foi recorrente durante o trabalho de campo, sendo dita principalmente pelo locutor Sandro "Testinha” em vários momentos

161 Para alguns interlocutores, esse fato torna-se ainda mais nítido: o skate é um meio de diversão, mas também é uma forma de trabalho. Portanto, como ouvi de um skatista, eles "trabalham com aquilo que dá prazer". Basta lembrar-se dos skatistas profissionais, que exercem ali a função de juízes a partir da prática do skate, ou então, do skatista Raphael "Pezão", que trabalha como videomaker (de forma simultânea a prática do skate, que é considerada por ele uma "diversão").

${ }_{162}$ Com base no trabalho de campo realizado, percebe-se que o skate - para usar uma terminologia de Archetti (2003), tal como discutida por Toledo (2009) - pode ser visto como detentor de um princípio simbólico híbrido, situando-se nos interstícios do lazer e do esporte; do lúdico e do competitivo; do amadorismo e do profissionalismo; do marginal e do socialmente aceito; do público e do privado; do prazer e do risco. Conforme será visto ao longo de toda a etnografia, o skate é praticado de distintas maneiras e com as mais diversas intenções. Ressalto que Archetti (2003), ao propor a terminologia citada nesta nota, não analisava a prática do skate, mas outras práticas, como futebol e o pólo. No entanto, vejo relações entre o que foi apresentado por esse autor e o objeto desta pesquisa.

163 Os skatistas estão todos juntos, pois se reconhecem como tais; mas, estão misturados, pois cada um é portador de uma série de particularidades, resguardadas em seu ethos, capaz de diferenciá-lo dos outros. 
da competição. Durante cada etapa, conforme apresentado ao longo deste capítulo, encontramos skatistas com roupas muito largas ou muito justas, garotos e garotas, crianças e jovens, com nível técnico principiante ou avançado, da cidade de São Paulo ou do interior. Todos se reconhecem como skatistas e compartilham um sentimento comum, através da apreciação de um símbolo unificador. O skate, visto através de seus aspectos simbólicos, nos diz muito sobre aquele que o porta: na lixa pode haver certos escritos sobre a localidade da qual é proveniente; no shape podem estar colados adesivos de marcas especializadas que revelam a que estilo tenta seguir; e até mesmo a forma como as peças são gastas e os seus respectivos tamanhos fornecem pistas sobre como o skatista executa a sua manobra, bem como sua técnica.

Todas as diferenças entre os skatistas poderiam levar a alguns momentos de tensão, por conta das divergências expressas em seus gostos e nos distintos sentidos atribuídos à prática do skate, o que culminaria, talvez, em um clima de hostilidade. Entretanto, há um tipo de relação estabelecida entre eles que propicia, até certo ponto, a manutenção de seus vínculos: trata-se das relações jocosas ${ }^{164}$, ou seja, um momento de gozação recíproca, por meio de zombaria, em que skatistas "tiram sarro" uns dos outros. É comum ver um skatepunk zombando um gangueiro por conta de suas roupas e viceversa; ou então um skatista proveniente de uma localidade fazendo piadinhas com outros por conta de onde moram. Sobre essa zombaria, alguns skatistas me disseram que:

Sempre tem zoação. Não só aqui no Brasil, mas com certeza em outros lugares. (...) No meu pensar, não tenho nenhuma dificuldade em lidar com um cara que curte reggae, um cara que curte rap mais pesado, cara de gosta de um som mais leve, ou cara que é punk mesmo... Admiro todos (Everton Canuto, entrevista em 26 de março de 2010).

Tem muita tiradinhas entre uns e outros. Se você é muito gangueiro, então vai tirar uma com o cara do rock: "essa calça está muito na bunda". E vai rolar uns comentários assim. Mas todo mundo se respeita. Quando um

\footnotetext{
164 Pereira $(2009,8)$ salienta, partindo da definição de relações jocosas de Radcliffe-Brown (1989), que esse tipo de relação pode ser simétrica ou assimétrica: "no primeiro caso, cada uma das pessoas pode brincar com a outra. No segundo, um indivíduo pode brincar ou insultar o outro, mas este não pode fazer retaliações, aceitando os gracejos com bom humor; ou, ainda dentro do campo das relações assimétricas, um indivíduo pode zombar com o outro o quanto desejar, enquanto este outro, por sua vez, pode apenas retribuir um pouco a gozação".
} 
gangueiro volta uma manobra legal, o rockeiro vai bater palmas e vice-versa (Jorge Costa, entrevista em 19 de março de 2010).

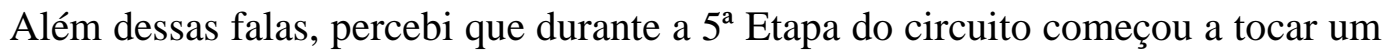
rap. Alguns skatistas se levantaram e começaram a "zoar", dançando a música de uma forma engraçada e fazendo paródias aos movimentos corporais comumente feitos por rappers, em que balançam a mão repetidamente de cima para baixo. Já na $3^{\text {a }}$ Etapa, havia um skatista baiano, um sergipano e alguns paulistas. $\mathrm{Na}$ ocasião, cada um "gozava" do outro por conta do Estado que eram provenientes. Enfim, são diversos exemplos em que a possibilidade de hostilidade dá lugar aos risos e, conseqüentemente, a uma interação por conta da diferença.

\section{8 - "Agora vou andar de skate de verdade"}

As etapas do Circuito Sampa Skate terminam, mas isto não quer dizer que os skatistas percam os contatos estabelecidos. Eles saem do ginásio na companhia dos outros (geralmente, com os mesmos que vieram), e aqueles que não conseguem carona vão em direção ao ponto de ônibus ou estação de metrô mais próxima. Tive a oportunidade de acompanhar vários desses momentos. Como as etapas acontecem geralmente em regiões distantes do Centro, os skatistas, para se localizarem mais facilmente, pegam alguma condução que passe em uma área de fácil acesso a todos ${ }^{165}$. Desse modo, vários deles circulam juntamente pela cidade, até certo ponto em que se dispersam. E durante o trajeto, alguns ainda têm fôlego para andar ainda mais de skate, dessa vez não em uma pista, mas nas ruas.

O skatista Alexandre "Cotinz", ao ir embora da $1^{a}$ etapa, foi andar de skate em alguns equipamentos públicos da cidade, junto de seus amigos. Antes de partir, ele me disse: "estou indo andar na rua. Agora vou andar de skate de verdade..." (Grifos meus).

\footnotetext{
165 Após o término da $4^{\circ}$ Etapa, realizada na Vila Olímpica Mário Covas (Zona Sul), todos os skatistas presentes no campeonato saíram juntamente. Cada um deles mora nas mais diversas partes da cidade (ou até fora dela) e o local em que estávamos não dispunha de transporte público para todas essas localidades. O ponto de ônibus estava cheio e vários skatistas adotaram a seguinte tática: pegaram um ônibus que fosse até a Rua da Consolação e de lá seguiram para a Avenida Paulista, onde pegaram outro ônibus ou metrô. Após um tempo passou o ônibus e diversos skatistas entraram simultaneamente. Antes de passar pela catraca, alguns tentaram levar o cobrador "na humildade", através de um discurso de que não tinham dinheiro, que estavam longe de casa e que necessitavam de ajuda. Para não criar caso, o cobrador deixou os skatistas passarem por debaixo da catraca. Porém, nem todos se aproveitaram dessa permissão. Após um longo trajeto, todos desceram do ônibus. Mesmo depois de um dia inteiro de campeonato, alguns skatistas ainda tinham ânimo para andar de skate nos equipamentos públicos da Avenida Paulista.
} 
E não foi só esse skatista que conferiu importância ao skate praticado nas ruas. Vários outros me disseram que participam do Circuito Sampa Skate, que é um campeonato realizado em uma pista, mas nem por isso andam somente ali, pois preferem as ruas. $\mathrm{O}$ próprio skatista Alexandre "Nicolau", freqüentador assíduo das etapas, confessa que:

[O Circuito Sampa Skate] é legal cara. Mas campeonato não é o foco principal do skate. Acho que é andar de skate na rua, desenvolver um trabalho na rua, que é o verdadeiro street, que é a "modalidade" (Entrevista em 26 de março de 2010, grifos meus).

Rodrigo "Bocão" acredita que, de certa forma, por meio das experiências compartilhadas durante os campeonatos, os skatistas são influenciados a andar nas ruas:

Tem bastante molecada que está começando a andar e não vai muito para os lugares. Ainda não tem aquela meta de sair para os lugares, para fotografar. Mas aí eles vão vendo [o Circuito Sampa Skate] e adquirindo isso aí, de poder sair para a rua para filmar, e gostando cada vez mais do skate. Tem molecada nova que tipo, foi no campeonato, correu e acho legal. Mas nem andava muito de skate. Depois do campeonato vai gostando mais e vai indo [para as ruas] (Entrevista em 17 de março de 2010).

(...) A molecada nova está no campeonato e se conhece. Também têm os outros que estão na rua fazendo um trampo. Eles começam a "colar" junto e vão aprendendo outras coisas com as pessoas que estão mais tempo ali andando, fazendo outras coisas também além do campeonato (Entrevista em 17 de março de 2010).

Sandro Sobral, skatista profissional, disse-me que o circuito é uma "porta de entrada" no universo do street skate, tanto para aqueles que almejam vivenciar as experiências de "ser skatista", quanto para aqueles que queiram consolidar uma carreira como profissionais ${ }^{166}$. E foi por meio dos convites dos próprios skatistas que eu tive a

\footnotetext{
166 Sandro Sobral ainda pontua que “o 'Sampa' é um trabalho legal, um projeto social, de inclusão social da molecada, de campeonatos nas periferias. Muitos moleques saíram de lá e agora conseguem ser skatistas famosos. O "Maizena" [Rodrigo "Maizena", skatista profissional] mesmo foi um deles. Tem um monte de moleque. É uma porta de entrada para a galera te ver. De repente, você pode ganhar o circuito, estar entre os dez do circuito. O da vez agora é o Kelvin [Kelvin Hoefler, considerado pelos skatistas uma promessa do skate profissional]. Os moleques começam a crescer neste campeonato, começam a correr em todos e se dar bem, pegar a base. O 'Sampa' tem quase todo fim de semana, então você fica naquele ritmo. Eu acho muito louco" (Entrevista em 31 de março de 2010, grifos meus).
} 
chance de passar por essa "porta de entrada" e de acompanhá-los em seus "rolês" pela cidade, tendo em vista a busca de lugares skatáveis ${ }^{167}$.

\section{ICONOGRAFIA - CAPÍTULO I}

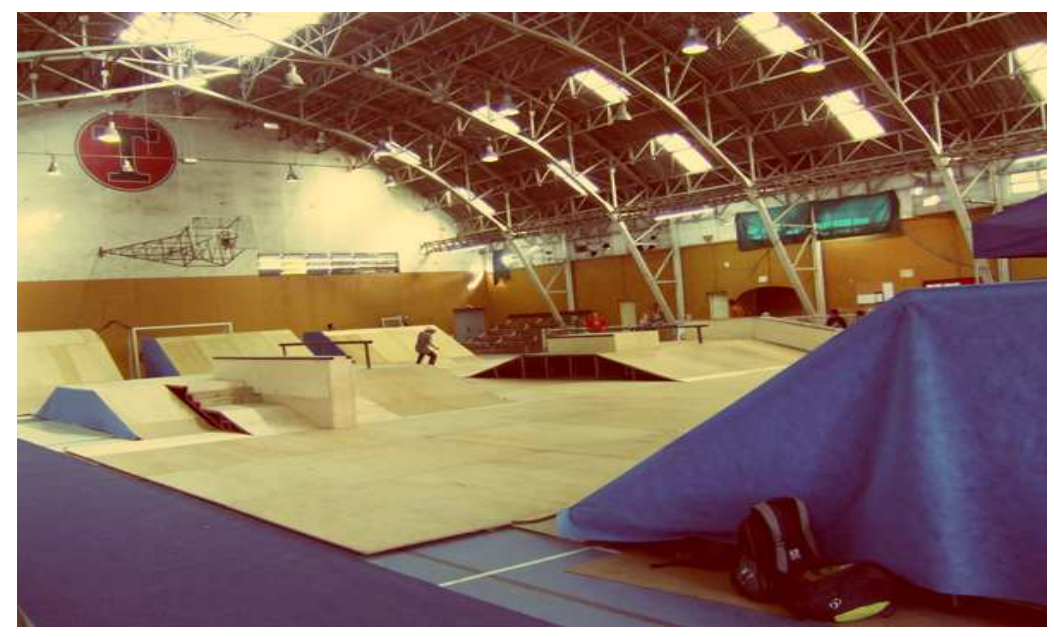

Vista parcial da pista de skate (foto: G. Machado)

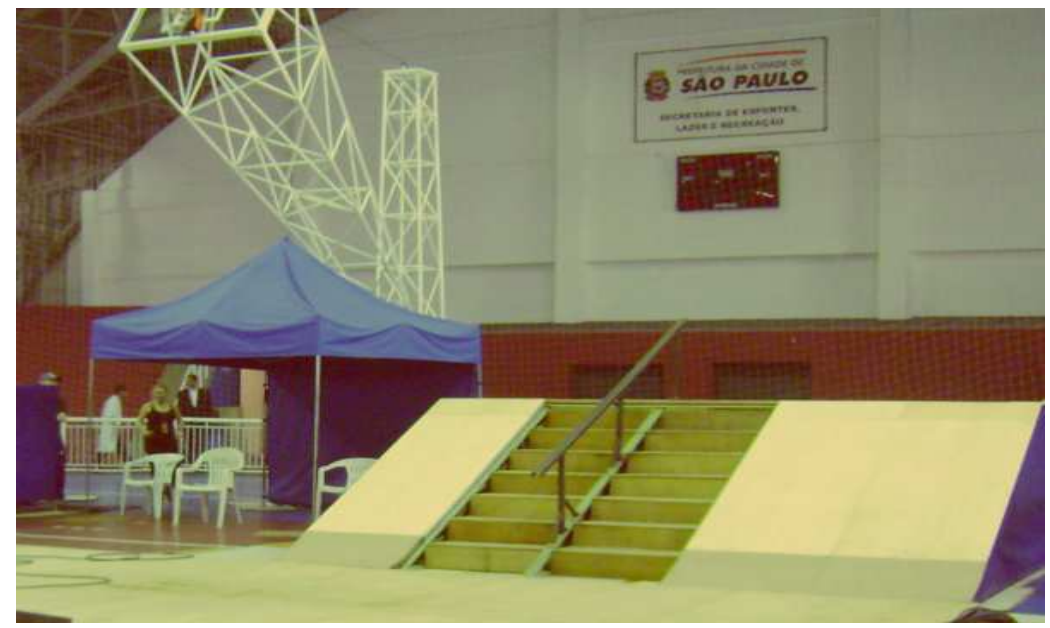

Alguns obstáculos da modalidade street skate simulam equipamentos urbanos encontrados nas ruas, como escadas e corrimãos (foto: G. Machado)

167 Lugares skatáveis é uma expressão nativa que será detalhada no próximo capítulo. 


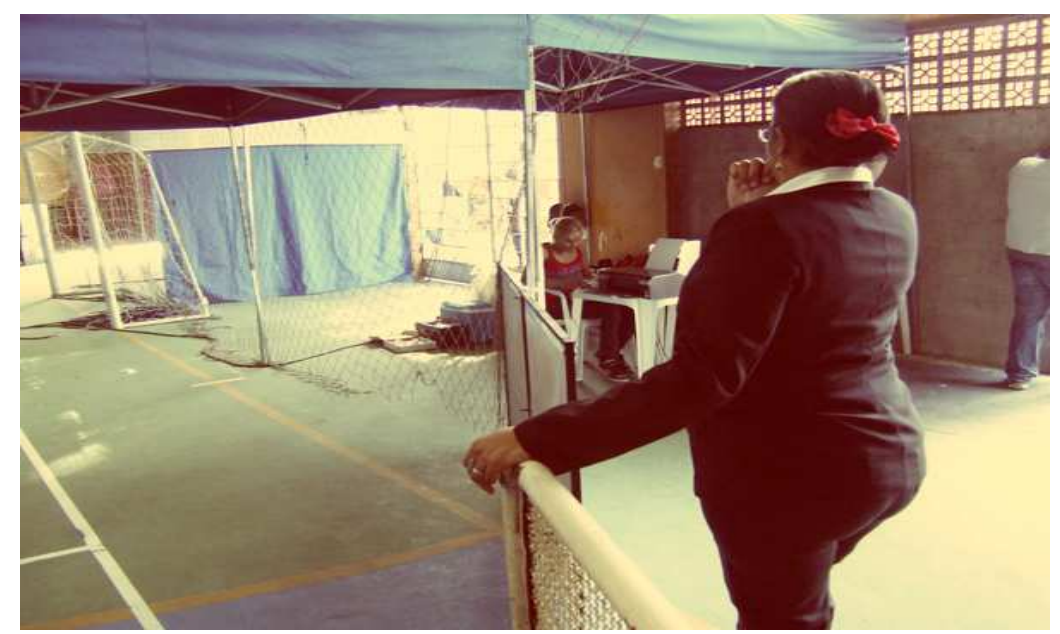

Entrada para a pista. Ao fundo, tenda onde se faz as inscrições dos competidores (foto: G. Machado)

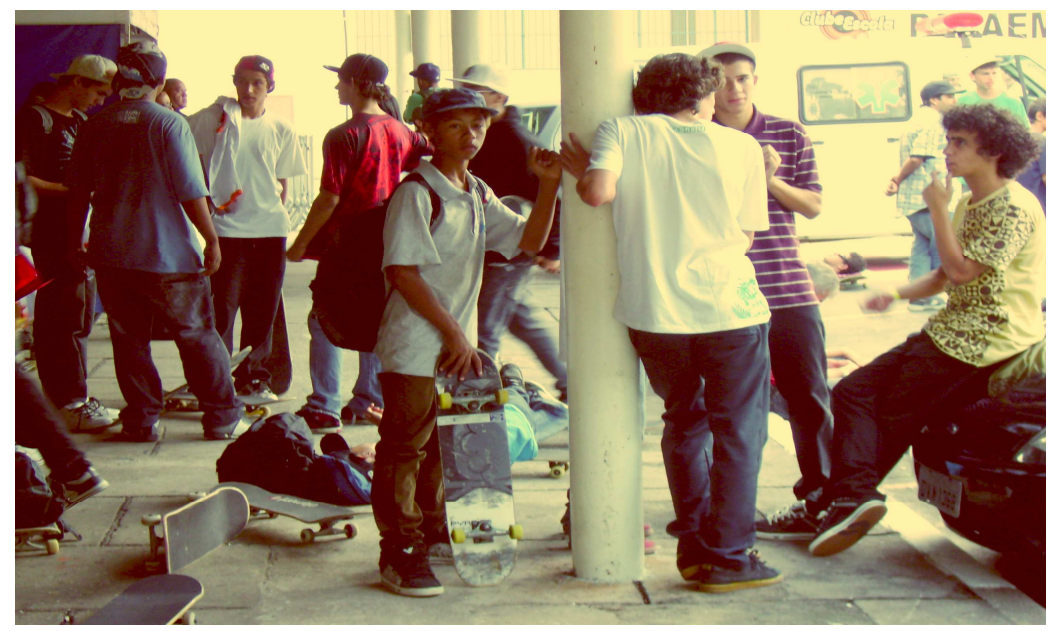

Sociabilidade entre os skatistas do lado de fora do ginásio (foto: G. Machado)

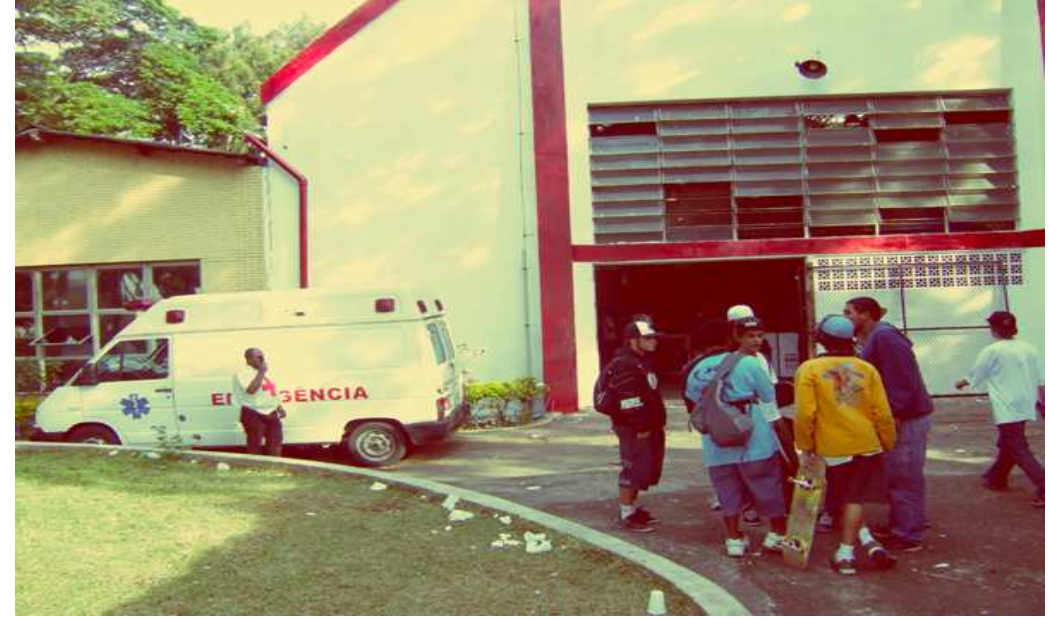

Ambulância, para casos de emergências (foto: G. Machado) 


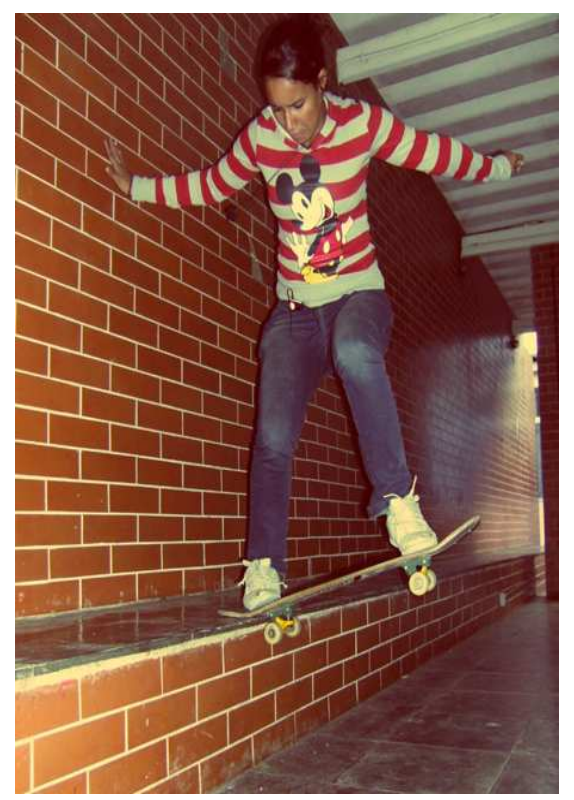

A skatista Mariana Nunes utiliza o equipamento de um dos clubes que sediou a etapa do Circuito Sampa Skate (foto: G. Machado)

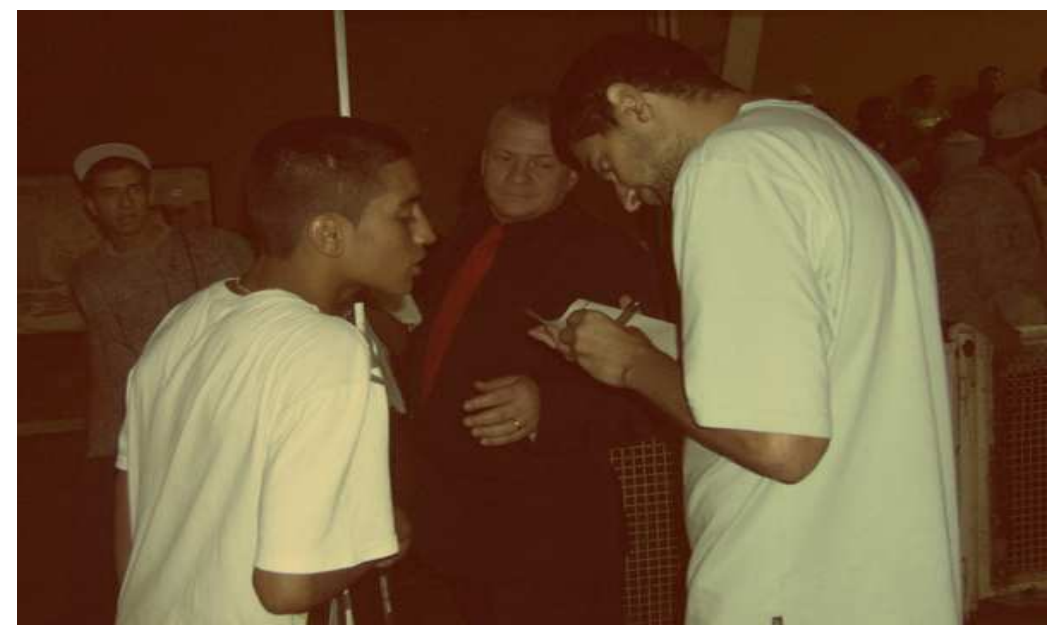

Antes de entrar na pista, o skatista necessita comprovar que é competidor (foto: G. Machado)

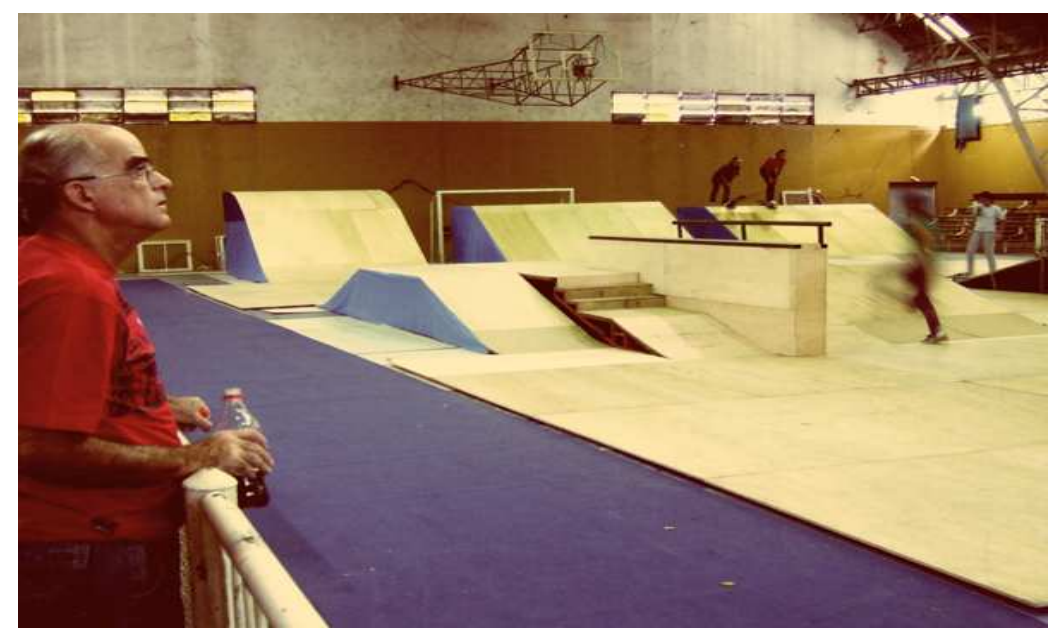

Pai de um skatista presente no Circuito Sampa Skate (foto: G. Machado) 


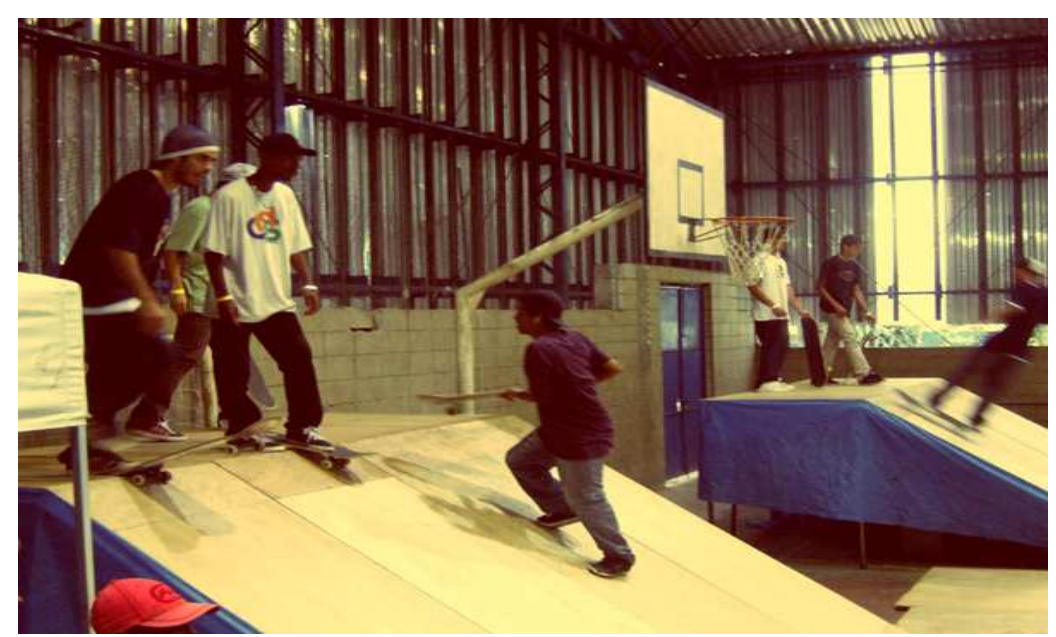

Alexandre "Nicolau" (de camiseta preta) se prepara para dropar (foto: G. Machado)

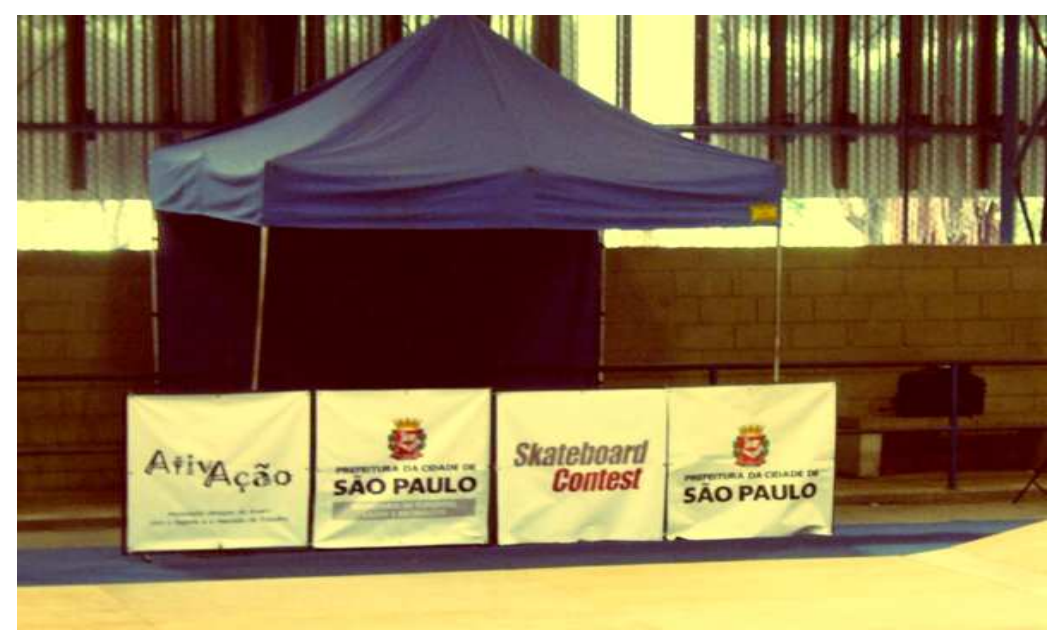

Banners dos promotores do Circuito Sampa Skate (foto: G. Machado)

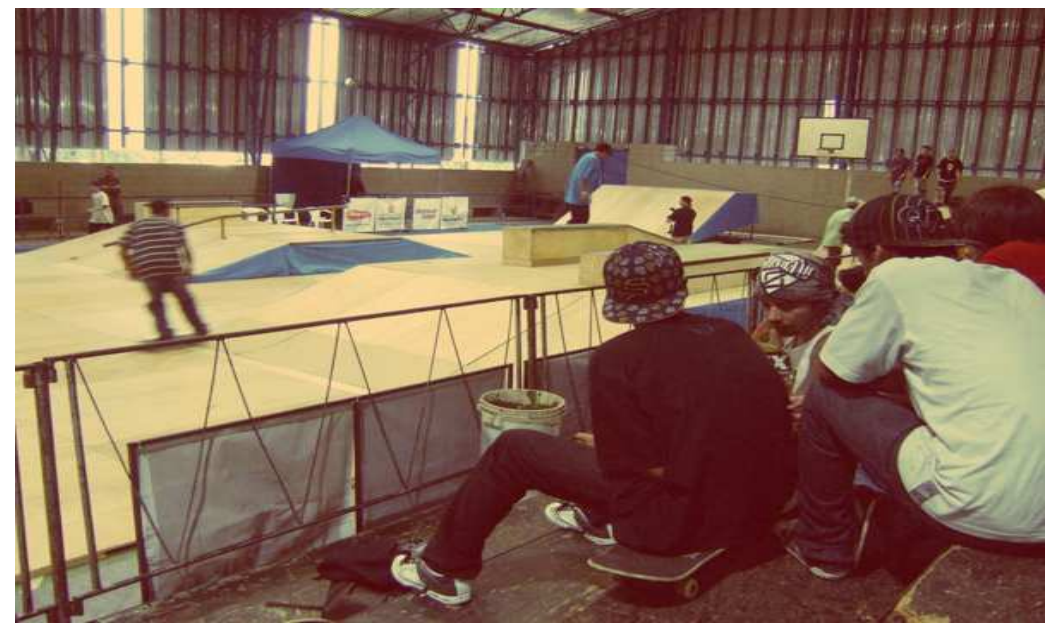

Skatistas aguardam na arquibancada o momento de suas voltas na competição (foto: G. Machado) 


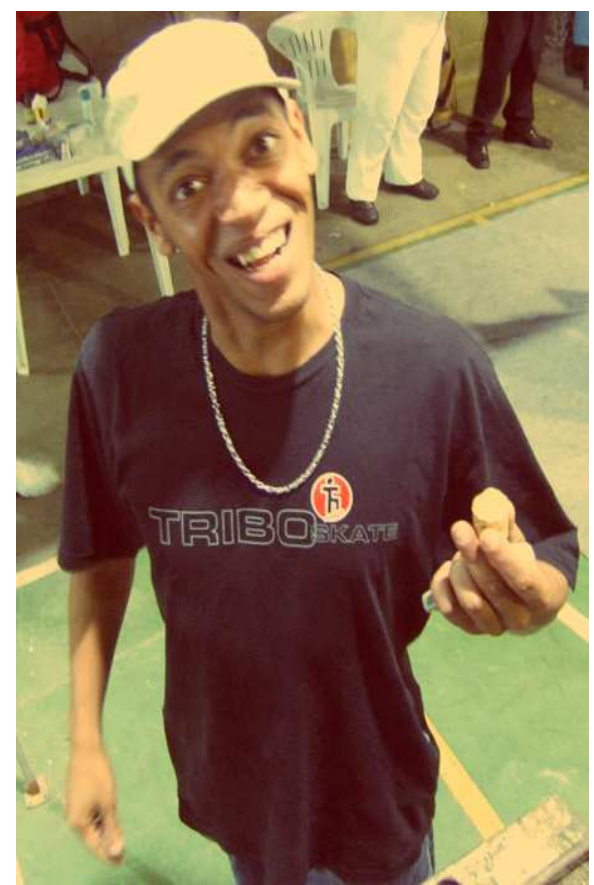

Sandro "Testinha", locutor do Circuito Sampa Skate (foto: G. Machado)

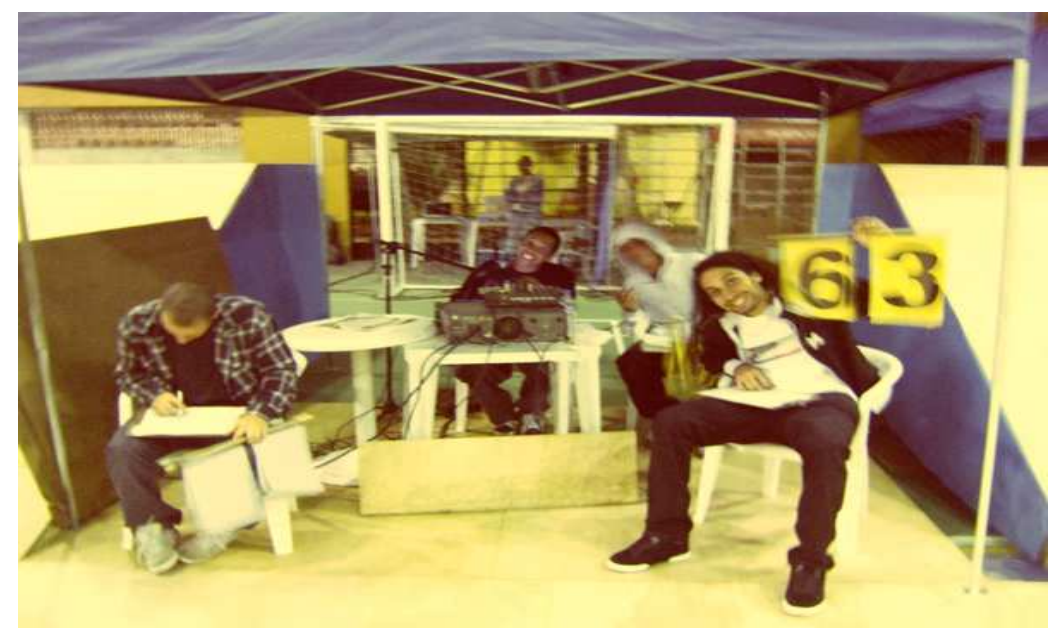

Juízes e locutor da competição. Da esquerda para direita: Sandro Sobral, Sandro "Testinha", Gian Naccarato e Masterson "Magrão" (foto: G. Machado)

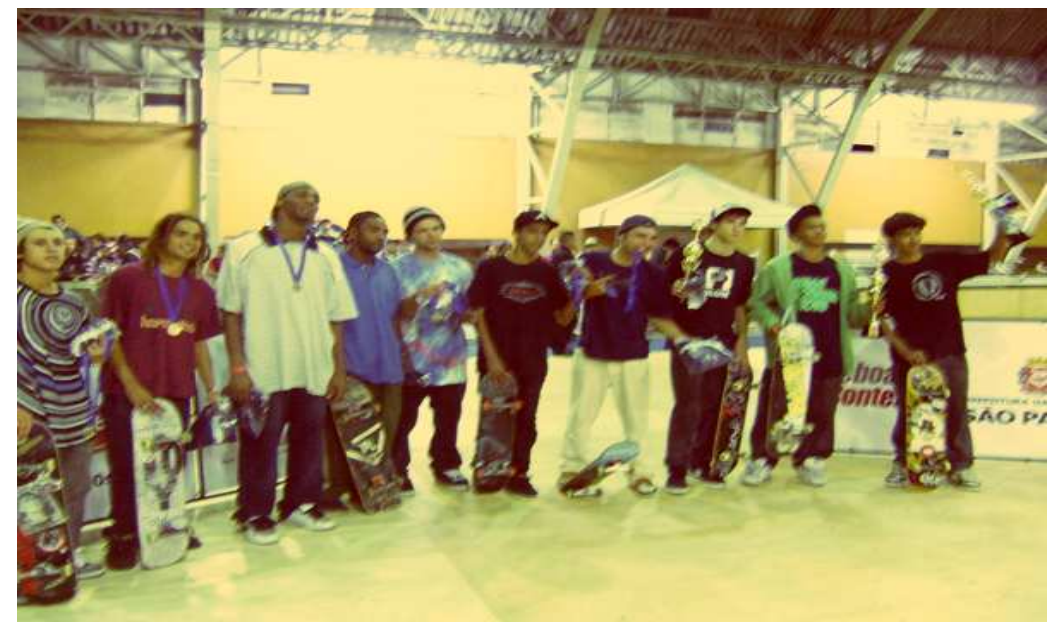

Finalistas da categoria Amador I com suas respectivas medalhas e troféus (foto: G. Machado) 


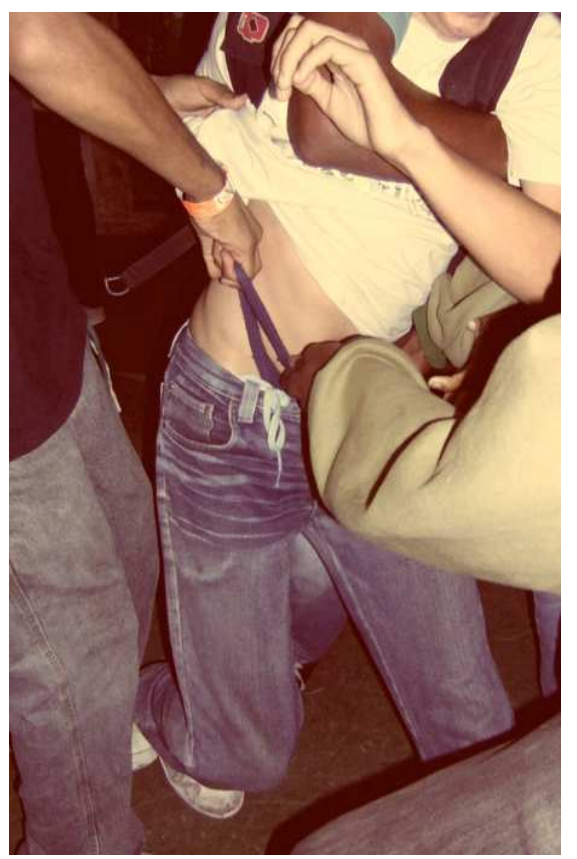

Após a premiação, o momento do "cuecão" (foto: G. Machado) 


\section{Capítulo II - Entre as pistas e as ruas: em busca de lugares skatáveis}

\section{1 - Pistoleiros e streeteiros}

Como já descrito no capítulo anterior, durante o ano 2009, acompanhei diversas etapas do Circuito Sampa Skate, a maioria realizada em locais distantes da região central de São Paulo. Caso algum skatista quisesse competir, necessariamente teria de se deslocar pela cidade, para acompanhar o caráter itinerante do circuito. A partir dessa dinâmica, a sociabilidade tecida alarga-se, levando o skatista a se relacionar com outras pessoas e a participar de inúmeras situações. Nos contextos pesquisados, observa-se ainda que, apesar da importância das competições no universo do skate, os skatistas nem sempre as tratam com prioridade ${ }^{168}$. As etapas desse circuito evidenciam tal aspecto. Sendo assim, a visão construída por alguns agentes de que a prática deve ser realizada preferencialmente em espaços "próprios", ou seja, em pistas, não é absolutamente compartilhada ${ }^{169}$. Em meio a tudo isso é possível notar a posição do poder público como incentivador do lado competitivo e esportivo do skate, e também, como disciplinador dos usos e apropriações dos espaços urbanos.

A partir das falas e das práticas dos skatistas percebe-se que as ruas, ao contrário das pistas, são evocadas a todo instante:

A rua é praticamente a minha segunda casa. Mesmo se for para uma pista, o cara que anda de skate mesmo, vai mandar manobra na rua (...). Eu acho que a rua é a segunda casa de todo skatista, ou pelo menos da maioria (Alexandre "Nicolau", entrevista em 26 de março de 2010, grifos meus).

Nesse sentido, saber andar de skate não só em pistas, como também nas ruas, é algo que possibilita reconhecimento, uma vez que o praticante torna-se bem visto perante os demais. Durante o trabalho de campo muitos skatistas me disseram que Kelvin Hoefler, campeão do Circuito Sampa Skate na categoria "amador I" ${ }^{170}$, é um típico "campeonateiro" ${ }^{171}$, tendo a sua imagem associada, sobretudo, a prática em

\footnotetext{
168 Esse fato é evidenciado no primeiro capítulo. Os skatistas participam dos campeonatos, porém atribuem distintos significados às disputas.

169 Como se verá adiante, não é só nas pistas onde boa parte dos streeteiros procura andar de skate.

170 Na modalidade street skate, a categoria "amador I" antecede o profissionalismo.

171 Termo usado por um skatista, para definir sua impressão sobre Kelvin Hoefler.
} 
pistas. Para tentar deixar de lado esse estereótipo, este skatista estaria se dedicando também ao skate nas ruas, como se comprova por meio de uma entrevista a uma revista especializada, onde todas as fotos de manobras foram feitas em vários equipamentos urbanos ${ }^{172}$. Kelvin então salientou que: "meu skate evoluiu bastante e descobri o prazer de andar na rua. A rua fez o meu skate amadurecer e facilitou minha vida nos campeonatos" (Revista CemporcentoSkate, 2010, 145, grifos meus).

Por andarem exclusivamente em um único local restrito e com poucos obstáculos, os skatistas que ficam confinados às pistas de skate são tratados jocosamente como pistoleiros:

A rua te dá base para você virar um streeteiro pesado. Streeteiro pesado é assim: um cara de nível, um skatista completo para a rua. A pista te dá uma base. Só que aí você vai virar pistoleiro. Cara que curte andar mais em transição ("Gui”" Martins, entrevista em 24 de março de 2010).

Para o skatista e empresário Fábio Brandão, a pista de skate possui sua importância. Entretanto, desprezíveis são os que vão até lá com intuito de mandar "manobras bitoladas" ${ }^{173}$ :

O skate na pista é bonito para caramba. Hoje em dia você vê os caras andando em pista, é muito louco. Os caras andam muito. É muito style. Os caras agressivos mesmo, que andam em transição. Pista que eu digo é transição ${ }^{174}$. Não um moleque que vai à pista e fica mandando "manobra bitolada". Os caras de pista mesmo estão andando muito (Entrevista em 13 de abril de 2010).

Por outro lado, Raphael "Pezão" acrescenta que "a maioria dos caras que colam em pista não erram [as manobras]. Não querem errar. Querem treinar para sempre". Muitas vezes a figura do pistoleiro associa-se à do skatista "campeonateiro" ou a do "robozinho" ${ }^{175}$, isto é, aquele que se centra no treinamento exaustivo de manobras para

172 Além dessa entrevista, Kelvin Hoefler foi vencedor do "Desafio de Rua", evento promovido pela Revista CemporcentoSkate, no ano de 2010. Esse evento possui um formato diferenciado de competição, a qual não é realizada em uma pista de skate, mas em picos de rua.

173 "Manobras bitoladas" é uma expressão utilizada por Fábio Brandão para se referir àqueles skatistas que vão à pista somente para treinar um único tipo de manobra.

174 "Transição" é um termo utilizado para definir diferentes tipos de rampas inclinadas.

175 Sobre "skatista robozinho", vide Capítulo I. 
competições ${ }^{176}$ em espaços que apenas simulam os obstáculos encontrados nas ruas e nem sempre se diverte com a prática do skate ${ }^{177}$. Esse skatista estaria próximo do "atleta", levando em conta o sentido atribuído ao termo por alguns interlocutores. Sendo assim, o que mais importa para esse tipo de praticante é o aperfeiçoamento por meio da repetição, a fim de incorporar a técnica e habilidade necessárias para o exercício da prática esportiva, tendo em vista a busca de resultados práticos ${ }^{178}$.

Raphael "Pezão" é crítico ao dizer que muitos skatistas que andam somente em pistas se tornam acomodados. Nas ruas, os streeteiros encaram diferentes tipos de obstáculos, muitos deles improvisados, que surgem no decorrer da prática. Os pistoleiros, ao contrário, em vez de buscarem novos espaços, contentam-se com aquilo que já está pronto:

Pistoleiro é uma galera preguiçosa. Mas por que rola preguiça? Você vai à pista, estão todos os obstáculos lá. Você prende sua evolução. Você evolui, mas, só evolui ali. Se os obstáculos mudam, a sua evolução quebra (Entrevista em 29 de março de 2010).

Consoante a isto, a prática neste espaço restrito se constitui, até certo ponto, sem tantas inovações:

\begin{abstract}
Andar de skate na pista é tipo aquela idéia: é andar de skate num lugar que foi feito para você andar mesmo, e você vai, põe o skate no pé, e você fica andando. É um lugar para você andar de skate. Já na rua você descobre as coisas (Rodrigo "Bocão”, entrevista em 17 de março de 2010).
\end{abstract}

A evolução a que Raphael "Pezão" se refere não é só em termos técnicos. Ela também pode ser entendida como uma ampliação da sociabilidade tecida pelos skatistas

\footnotetext{
176 Bob Burnquist, considerado pela mídia um dos melhores skatistas brasileiros de todos os tempos, em entrevista para o site do canal ESPN, afirmou com convicção que: "eu nunca treinei um dia sequer na minha vida. Eu ando de skate, estou andando de skate" (Disponível em http://espnbrasil.terra.com.br/skate/noticia/129391_EXCLUSIVO+EU+NUNCA+TREINEI+UM+DIA+S EQUER+BOB+BURNQUIST. Acesso em 29 de janeiro de 2011). Desse modo observa-se que até mesmo muitos skatistas profissionais tidos como referências no universo do skate, constroem discursos que não associam à prática ao treinamento, mas sim, ao que chamam de "diversão".

177 Como pode ser visto ao longo desta pesquisa, "diversão" é um termo constantemente acionado pelos interlocutores para definirem e distinguirem a prática do street skate de um simples treinamento.

178 A busca por resultados práticos se associa aos praticantes que visam somente ganhar campeonatos, conseguir patrocínios e, também, obter ganhos financeiros com a prática do skate. Obviamente, muitos interlocutores buscam tudo isso, embora acreditem que outras experiências e finalidades sejam mais importantes no universo do street skate.
} 
na metrópole. As falas desse e de outros skatistas abordados nesta pesquisa supõe que os relacionamentos dos pistoleiros concentram-se, sobretudo, na própria pista de skate onde se costuma andar. Os streeteiros, por sua vez, não possuem tanta fixidez para a prática do skate, visto que ela pode ser feita em muitos espaços. Com efeito, suas redes de relações se expandem à proporção que novas sessões nas ruas são feitas, as quais propiciam o estabelecimento de novos contatos.

Rodrigo "Bocão" pondera que o fato de um skatista andar em uma pista se dá por questões práticas, como a proximidade da residência. Além do mais, um pistoleiro pode surpreender um streeteiro com seu nível técnico em uma eventual sessão na rua:

Hoje em dia muitas pessoas falam: "ah, o pistoleiro". Mas essas pessoas têm uma base de skate. Eles estão ali porque a pista está perto de casa. Eu ando no "Vale" [do Anhangabaú] e os caras falam: "você não anda em pista, só anda na rua!". Mas é o lugar que eu tenho para andar. Tem gente que gosta de andar na pista porque é o lugar que está ali todo dia, como eu estou todo dia andando no "Vale", trocando idéia. Mas às vezes, o pessoal fala: "ah, esses pistoleiros só fica andando nas pistas". Mas às vezes esse pessoal vai andar na rua e acaba com esse pessoal que critica eles, porque aí vê uma foto: "pô, maluco fez uma foto em tal corrimão na rua! (...) Maluco pulou tal gap!". Andar na pista também dá uma base no skate, e muita gente consegue levar esse skate para a rua também (Entrevista em 17 de março de 2010, grifo meu).

Portanto, tais discursos atestam que não se deve deixar de andar de skate em pistas. Andar nelas é importante para os skatistas da modalidade street skate. Porém, o que se critica são aqueles que se prendem unicamente a elas ${ }^{179}$, sem circular por outras pistas ou equipamentos urbanos da cidade e, conseqüentemente, sem estabelecer novas relações.

O skatista Jorge Costa, assim como muitos outros, anda de skate tanto nas pistas quanto nas ruas. Com base em sua experiência, ele aponta algumas diferenças entre esses dois tipos de espaços:

Andar em pista também é uma coisa difícil. Para você conseguir chegar a um estágio de começar andar bem, distribuir as manobras nos obstáculos

179 São poucos skatistas que se reconhecem como pistoleiros. Em certa medida, essa é uma categoria acusatória. 
sem por a mão no skate, é uma coisa bem difícil. Quem anda de skate na rua vai sempre andar de skate em um obstáculo por vez. Geralmente ele é um cara meio lento na pista, enquanto na rua ele é o "cara" (Entrevista em 19 de março de 2010).

Cada espaço para a prática do skate permite ao skatista desenvolver tipos de habilidades específicas, as quais são expressas por meio de suas técnicas nas manobras realizadas. Desse modo, Jorge Costa ressalta que para um skatista se tornar "completo", ele tem de saber andar em vários tipos de "terrenos":

O skate é muito complexo. Se você consegue se desenvolver bem em um terreno, vai ter muita dificuldade para fazer as suas coisas em outro terreno. Você precisa doar seu tempo de forma conjunta. Para você conseguir andar bem nos dois terrenos você precisa sempre estar se dedicando, no street $\mathrm{e}$ em pista. É muito difícil (Entrevista em 19 de março de 2010).

Douglas Prieto, colunista de uma revista especializada, em um texto intitulado "Diferentes terrenos, diferentes skatistas", resume as técnicas e as habilidades incorporadas pelos skatistas conforme o "terreno" onde se pratica:

Nas pistas encontradas na América do Norte, especialmente nos EUA e Canadá, abundam curvas e transições. Esse tipo de pista forma um skatista mais "basudo", mais "todo terreno", mais fluido. Os skatistas se criam nessas pistas e ainda têm a oportunidade de desenvolver a técnica do street "real" graças à grande quantidade de bons picos de rua (apesar da repressão encontrada por lá, mas isso é outra história). Resultado: unindo o melhor dos dois mundos, está formado um skatista mais completo, porém não tão especialista num ou no outro terreno. Por outro lado, qualquer moleque brasileiro bem treinado sabe montar uma boa linha de 1 minuto numa área de competição, e executá-la precisamente. Por isso que os campeonatos amadores daqui pegam fogo, e surgem tantos vencedores de campeonatos. $\mathrm{O}$ que é interessante ressaltar é que as pistas brasileiras construídas recentemente passaram a incorporar mais curvas e transições. O novo projeto do Paço Municipal de São Bernardo, alguns dos CEUs e o banks de madeira da Plasma ${ }^{180}$ são exemplos reais dessa tendência ${ }^{181}$. Será interessante observar como os moleques que estão iniciando agora farão uso

180 Banks da Plasma é uma pista localizada no Shopping Aricanduva, Zona Leste da cidade.

181 Tendência a construir pistas para várias modalidades em um único espaço. 
desse novo cenário. Creio que seja uma questão de formação do skatista, "berços" diferentes, que geram duas escolas diferentes: uma dos que sabem fazer um carving antes de acertar um flip, outra dos que aprendem um flip crooked antes de aprender a dropar num transição (Disponível em: http://cemporcentoskate.uol.com.br/blogLer.php?categoria=9. Acesso em 25 de janeiro de 2011, grifos meus).

Tal skatista "completo" 182 " "basudo" ou "todo terreno" é chamado de overall. Um skatista overall é aquele que pratica várias modalidades e sabe andar em vários tipos de obstáculos. A Revista Tribo Skate, em uma matéria especial sobre o tema, enaltece a importância deste tipo de skatista ${ }^{183}$ :

Diferentes terrenos, diferentes modalidades, diferentes carrinhos... O skate não se limita a uma determinada técnica ou especialização. A tábua com dois eixos e quatro rodinhas oferece "n" possibilidades. Ruas, madeira, asfalto, concreto, bordas, curbs, obstáculos, buracos, transições (...), tudo pode servir para ser explorado para seu prazer e diversão. Alguns skatistas sabem explorar as várias faces do skateboard (Revista Tribo Skate, edição $78,2002,38)$.

No universo da modalidade street skate, o skatista overall seria uma espécie de síntese entre o pistoleiro e o streeteiro. Além de tudo o que foi apresentado, o interlocutor Caio Youssef pontua que, nessa modalidade, é essencial dominar as técnicas de uma pista de skate, embora seja ainda mais importante andar nas ruas, pois lá se vivencia aquilo que pode ser considerado, a partir de seu ponto de vista, a "essência" do skate:

Cada um faz o que gosta. Só que o cara [que anda somente em pista] esquece a essência do skate. O skate não surgiu numa pista. O cara não foi lá e fez uma pista. O skate surgiu do nada e quando a sociedade foi ver havia

182 Como exemplo de "skatista completo", Jorge Costa cita Lucas "Xaparral", profissional eleito pela Revista CemporcentoSkate como o melhor skatista do ano de 2009: "você vê ele andando no banks. É muito difícil (...) as coisas que ele faz. Enquanto na rua ele é sem comparação também. Ele está num nível absurdo. É um skatista completo. Além disso, ele consegue se dar bem em campeonato. Ele é um cara, posso te dizer, que é único. É uma geração que conseguiu unir as duas coisas muito bem, ao mesmo tempo e com pouco tempo de skate" (Entrevista em 19 de março de 2010).

183 A própria Revista Tribo Skate ainda cria uma definição para o skatista overall: "skatista que tem por prioridade divertir-se ao máximo em cima do board, não amarelar diante de nenhuma situação ou terreno, seja ele um half, bowl, street, downhill, mini ramp (...). O overall é aquele que enfrenta todos os obstáculos, naturais ou não" (Revista Tribo Skate, edição 78, 2002, p.40). 
milhares de moleques na Califórnia, descendo ladeiras de skate, se matando, “causando" pela cidade. O skate surgiu assim. Não que o pessoal tem que "causar", sair zoando. O skate surgiu na rua. Para mim é assim: tem que andar um pouco na rua, a essência do skate é lá, se você quiser manter o que do jeito que ele é, tem que andar lá. Pista ajuda, dá base, você se diverte, mas tem que andar na rua (Entrevista em 15 de abril de 2010, grifos meus).

Abordadas as categorias nativas pistoleiro e streeteiro, nos próximos tópicos serão apresentadas etnograficamente as suas diferenças, sem perder de vista certas continuidades entre elas ${ }^{184}$. Atenta-se assim para os usos dos espaços e equipamentos urbanos por parte dos skatistas na metrópole e também para os discursos, muitas vezes políticos, que são construídos em torno do universo street skate. Primeiramente, serão abordados relatos do trabalho de campo realizado em uma pista e, em seguida, o foco será a prática do skate nas ruas - lócus, para alguns, da "essência do skate" ${ }^{185}$, onde se "anda de verdade" 186 -, levando em conta os principais espaços considerados pelos próprios skatistas na cidade de São Paulo.

\section{2 - Pistas de skate: uma alternativa para os skatistas?}

São Paulo é uma das cidades que mais possui pistas de skate no mundo. Em várias de suas regiões é possível encontrar estes espaços próprios para a prática, sejam eles particulares ou, principalmente, públicos. De acordo com o último levantamento feito pelo Guia de Pistas elaborado pela Revista CemporcentoSkate, até 2006 havia mais de sessenta pistas com área de street skate em toda a cidade, número que cresceu ainda mais nos últimos anos.

O surgimento de tantas pistas reflete o considerável aumento de praticantes, sobretudo após a década de 2000. A partir da constatação desse crescimento expressivo, o poder público passou a dar maior atenção ao skate. Nesse sentido, a escassez de espaços próprios para que milhares de skatistas pudessem praticar poderia trazer

\footnotetext{
184 Um pistoleiro pode se tornar streeteiro, assim como um streeteiro pode se tornar pistoleiro. Essas categorias são, portanto, relacionais.

185 Expressão usada com base nos discursos dos próprios interlocutores.

186 Expressão usada pelo skatista Alexandre "Cotinz".
} 
problemas. Ciente dos usos das ruas e de seus respectivos equipamentos, chegou-se a conclusão de que seria preciso dar-lhes uma "alternativa" ${ }^{187}$ :

[As pistas], apesar de não ser o street, é uma alternativa para o cara. $\mathrm{E}$ muitas vezes eu acho que o cara pratica o street porque ele não tem a opção de ter um espaço adequado. (...) Eu acho que é um pouco da posição do poder público de dar oportunidade. Seria mais contraditório eu falar o seguinte: "olha, saia da rua e ande na pista!". [O skatista vai falar:] "mas, em qual pista?”. Então não posso falar isto. Eu não posso incentivar uma coisa sem dar estrutura. Lógico, a gente vai tentando, vai fazendo aos poucos. Tem a Flávio Rangel, a Espraiada, a Saúde, a Sumaré ${ }^{188}$ (...). Eu acho que ele [o skatista] está muito na rua pela falta de estrutura e espaço adequado (Tiago Lobo, entrevista em 7 de outubro de 2009).

A partir dessa visão, certos agentes do poder público tentam coibir a prática do skate em espaços tidos como "inapropriados”, já que os skatistas, através da construção de pistas, teriam espaços reservados para suas atividades ${ }^{189}$.

Desde que assumiu a Coordenadoria de Esportes Radicais da prefeitura, em 2006, Tiago Lobo, já apresentado no capítulo anterior, passou a ser considerado por muitos o principal representante do poder público capaz de incentivar a prática do skate ${ }^{190}$. É a ele que os skatistas recorrem no momento de pedir apoio para a realização de eventos ou para reivindicar melhorias. Embora haja limitações e dificuldades em promover ações para o universo do skate, sobretudo para a modalidade street skate, Tiago considera que as "portas estão sendo abertas" para que os skatistas demonstrem seus anseios. Além disso, a coordenadoria descentralizou as mediações de modo que qualquer skatista pode ter acesso ao poder público:

Eu acho que o nosso trabalho aqui dá um pouco de resultado porque a gente incentiva que as pessoas nos procurem ou façam suas reivindicações. $\mathrm{O}$ trabalho aqui é muito descentralizado. A gente não faz nada aqui porque a

\footnotetext{
187 Tiago Lobo salientou também que, ao construir as pistas de skate, o objetivo não "é levar este público [os skatistas] e trancá-los num lugar (...). É justamente dar opção, já que ali [nas ruas] não está legal, que ali você sofre um tipo de restrição. O espaço público [das pistas] é seu [dos skatistas], onde o público fala a sua língua" (Entrevista em 7 de outubro de 2009).

188 Essas são algumas pistas públicas da cidade de São Paulo.

189 Os próximos tópicos abordarão de forma mais detida o que foi apresentado.

190 A frente da Coordenadoria de Esportes Radicais da Prefeitura de São Paulo, Tiago Lobo intermediou negociações em prol da realização de vários eventos voltados ao skate, dentre eles: Mega Rampa, X Games, campeonatos no Museu do Ipiranga, Circuito Sampa Skate, Circuito Universitário, entre outros.
} 
gente acha, porque o Tiago Lobo, que é coordenador de esportes radicais de São Paulo acha. Então, é o contrário. É o seguinte: o que a galera está querendo? Vamos fazer um campeonato de skate slalom ${ }^{191}$, por exemplo. Não sou eu quem define onde vai fazer, como vai fazer, se o formato é dual tight, se é individual, se é por tempo. Vamos chamar: quem é do slalom? Quem são os representantes natos? Quem fala com propriedade? Olha é Brunão, é Índio, é Batman... Ah, skate street. Vamos fazer um campeonato de street aqui? Não, cara, não sou eu quem vou definir se o piso é ou não é. Acho que é por isto que dá certo. E a gente abre muito as portas para todo mundo chegar aqui e reivindicar. Eu acho que esse é o segredo, não sei se é do sucesso, mas o segredo dessa facilidade do cidadão chegar aqui (Tiago Lobo, entrevista em 7 de outubro de 2009).

Através dessas mediações, entre 2008 e 2009, os skatistas da cidade de São Paulo tornaram possível a construção de uma pista pública na região do Sumaré, local considerado por muitos como o "berço" do skate paulistano ${ }^{192}$.

Na esquina da Avenida Doutor Arnaldo com a Rua Cardoso de Almeida, na Zona Oeste da cidade, havia um amplo espaço que servira como canteiro de obras para a construção da Estação Sumaré do metrô. Após alguns anos, a prefeitura resolveu transformar aquela área, de aproximadamente 2,3 mil metros quadrados, em um espaço de lazer. Sabendo dessas intenções, alguns skatistas se mobilizaram para reivindicar a construção de uma pista. E a mobilização, para a surpresa de alguns, foi bem sucedida.

Com tudo certo para o início das obras, os skatistas descobriram que o projeto da pista a ser feita não atendia às suas necessidades. Feito o alerta, formou-se uma comissão composta por skatistas moradores da região, além de profissionais da mídia especializada, empresários e membros da Confederação Brasileira de Skate (CBSk) ${ }^{193}$, a fim de fiscalizar tudo aquilo que fosse decidido e feito a partir de então. Com a ajuda de Tiago Lobo, o projeto inicialmente apresentado foi mudado, com as alterações feitas a partir de acordos entre os próprios skatistas.

Durante várias semanas, realizaram-se reuniões e trocas de e-mails entre os envolvidos na comissão, que se responsabilizaram por mediar as negociações com representantes do poder público. Tive a chance de participar de uma dessas reuniões.

\footnotetext{
191 Modalidade do skate onde o objetivo é descer ladeiras desviando-se de cones no chão.

192 Vide "A introdução dos esportes californianos no Brasil: apontamentos para o início de uma discussão" (Brandão, 2009, 18).

193 A Confederação Brasileira de Skate (CBSk) foi criada em 06 de março de 1999. Essa entidade visa regulamentar as normas e políticas voltadas ao desenvolvimento do skate no Brasil. Para mais informações, vide: http://www.cbsk.com.br.
} 
Além de Tiago Lobo e Arthur Soares, os quais representavam a Secretaria de Esportes, estiveram presentes pessoas detentoras de posições influentes, ligadas ao universo do skate, como Cesar Gyrão (editor da Revista Tribo Skate), Marcelo Santos (presidente da Confederação Brasileira de Skate), Flávio Ascânio (skatista e professor universitário), entre outros. A pauta girou em torno de três questões: os obstáculos, a qualidade dos materiais empregados e o prazo de entrega da obra. A preocupação em atender as diversas modalidades do skate e a acessibilidade às distintas gerações de praticantes, também foram questões que perpassaram os assuntos debatidos.

Depois de meses de muita mobilização e espera, em fevereiro de 2009 a pista foi inaugurada. A cerimônia contou com a presença de muitos skatistas, jornalistas, representantes do poder público e também de membros da família Natel, homenageada com a atribuição do nome "Parque Zilda Natel" ao lugar ${ }^{194}$. O prefeito Gilberto Kassab (DEM), que também esteve na inauguração, recebeu um skate de presente. Logo em seguida, segurando o presente, ele colocou um capacete em sua cabeça e posou para as fotos. Tal ato - um tanto simbólico - evidencia o posicionamento de agentes do poder público frente à prática do skate: um esporte "perigoso", que deve ser praticado sobretudo em pistas, cujos praticantes necessitam de cuidados com a proteção. Contudo, como será mostrado adiante, esse "perigo" é algo passível de ser relativizado, posto que muitos streeteiros nem sempre encaram dessa maneira aquilo que fazem.

Tiago Lobo considera essa mediação bem-sucedida e exemplo para que outros skatistas consigam seus objetivos perante o poder público. Além de tudo, construir uma pista no bairro Sumaré, região considerada "de rico" pelos skatistas, é uma prova de que o skate deixa parte de seu lado "marginal" ao promover, de acordo com o ponto de vista deste interlocutor, uma integração social:

\footnotetext{
Construir uma pista de skate em um bairro nobre de São Paulo é a prova da quebra de barreiras, que o skate quebrou barreiras. Quebra de paradigmas. Uma região de alto nível social com uma pista de skate. Choque cultural. Uma cidade tem que ter. E outra: não é colocar uma pista para pobre ir no lugar de rico (...) É integração social. O skate tem isto também. A partir do momento em que está na pista, anda o milionário com o moleque da favela. É um processo longo, de mudança da visão do skatista (Entrevista em 7 de outubro de 2009).
}

\footnotetext{
194 Maria Zilda Gamba Natel, ou simplesmente Zilda Natel, foi esposa do político Laudo Natel e exprimeira dama do Estado de São Paulo. Faleceu em 10 de dezembro de 2002, na cidade de São Paulo. Mais informações: http://www.eemariazilda.net.
} 


\subsection{1 - Parque Zilda Natel}

O Parque Zilda Natel, mais conhecido pelos skatistas como "pista do Sumaré", é uma ampla área localizada em um bairro nobre de São Paulo. Sua proximidade com uma estação de metrô e com a região central atrai skatistas de diversos pontos da cidade $^{195}$ e, até mesmo, de fora dela. Sua estratégica localização fez com que ela adquirisse visibilidade, se tornando uma das pistas mais freqüentadas dos últimos tempos ${ }^{196}$.

A área destinada ao skate no parque é composta por obstáculos referentes a três distintas modalidades: mini ramp, street skate e banks. Situados uns ao lado dos outros, em uma mesma sessão é possível utilizar todos os obstáculos ${ }^{197}$. Tal idéia, proposta pela comissão que orientou a construção da pista, permite que a mesma atenda ao maior número de modalidades possíveis, contribuindo para que muitos skatistas se tornem overall, isto é, aquele praticante que domina vários tipos de "terrenos".

Além desses obstáculos, o parque possui uma quadra destinada ao streetball (basquete de rua) ${ }^{198}$, aparelhos de ginástica e área de convivência, além de banheiro masculino e feminino, bebedouros, uma pequena arquibancada e muitos bancos para descanso. Para zelar por todos os equipamentos, fiscalizar as práticas esportivas e manter a "ordem" no local, o parque conta com o serviço de seguranças fardados, os quais observam tudo de uma guarita.

Para andarem de skate no Parque Zilda Natel, os skatistas devem cumprir uma série de recomendações que ficam bem claras desde a entrada no local, onde uma notável placa expõe oito orientações gerais:

\footnotetext{
195 Esta pista fica próxima à Estação Sumaré do metrô, na Zona Oeste de São Paulo.

196 Por meio de acessos a sites de revistas especializadas em skate pode-se comprovar a visibilidade da pista do Sumaré. Após a sua inauguração inúmeras matérias, fotos e vídeos foram feitas na mesma.

197 Ao se referir a esta diversidade de obstáculos feitos para distintas modalidades, Olic (2010, 48), em sua etnografia sobre a pista do CEU Butantã pontua que: "esta diversidade de obstáculos oferece aos skatistas uma ampla variedade de possibilidades, abrindo-lhes um campo maior de criação e construção de trajetórias múltiplas. Isto permitirá que, portanto, os skatistas não fiquem restritos somente a um ou outro obstáculo, como acontece em determinadas pistas, idealizadas a partir dessa segmentação entre as categorias".

198 Até a prática do streetball - como o próprio nome indica, basquete praticado nas ruas - aos poucos ganha espaços próprios na cidade, que são construídos pelo poder público.
} 
1 - Skate é um esporte perigoso, com risco de acidentes ${ }^{199}$;

2 - O uso do equipamento de proteção individual (capacete, joelheiras, cotoveleiras e tênis) é extremamente recomendado ${ }^{200}$;

3 - Respeite seus parceiros de sessão;

4 - Tenha consciência de seu nível técnico;

5 - Muita atenção com os outros usuários do parque;

6 - Informações sobre cada pista do parque, ou seja, o banks, a área de street e a mini rampa;

7 - O aquecimento e o alongamento são práticas importantes para evitar ou prevenir lesões;

8 - Consulte o regulamento completo na administração do parque.

Mais uma vez, ficam evidentes aspectos de como o skate é visto pelo poder público: uma prática esportiva que necessita de regulamentação. É válido ressaltar que a elaboração dessas orientações contou com a participação dos skatistas envolvidos na comissão antes apresentada. Mesmo assim, elas foram motivos de polêmica. Quando o parque foi inaugurado, o uso do capacete era considerado extremamente necessário. Porém, a partir de um dado momento, ele passou a ser obrigatório. Portanto, só se pode usar a pista caso o skatista tenha este equipamento. A medida contrariou muitos praticantes, principalmente os do street skate, modalidade em que quase nenhum skatista usa capacete ${ }^{201}$. Ao contrário, nas modalidades mini ramp e banks, o uso desse equipamento é mais freqüente. Foi decidido então que o capacete deveria ser usado por todos, independente da modalidade. Alguns skatistas, como o streeteiro Rodrigo Bocão, até deixaram de freqüentar o parque após a deliberação.

Sobre a polêmica, Jorge Costa opina que:

Você vai fazer street numa pista que só tem obstáculos baixos, você vai usar capacete para quê? Eu acho ridículo. Mas se você vai andar num banks altão, é bom você usar capacete, cotoveleira e joelheira. Tem que ser recomendado. Cada caso é um caso (Entrevista em 19 de março de 2010).

\footnotetext{
199 Grifos meus.

200 Grifos meus.

201 Os streeteiros, durante a prática do skate em equipamentos urbanos, não usam nenhum tipo de proteção. Somente em poucas competições feitas em pistas para a modalidade street skate é que alguns praticantes, que não são profissionais, usam o capacete. Por outro lado, em modalidades que se valem de rampas como half pipe e banks, o capacete e outras proteções são mais utilizadas.
} 
A alternativa desejável pelos skatistas abordados nesta pesquisa foi, de um modo geral, a de que o uso do capacete continuasse sendo recomendado, mas não obrigatório. Outra medida possível apontada por eles seria a assinatura de um termo de compromisso, por meio do qual o praticante se responsabilizaria por quaisquer lesões sofridas por não usar equipamentos de proteção ${ }^{202}$.

Um interlocutor, que optou por não citar o nome, acredita que a adoção dessa medida seja também uma tentativa de prática segregacionista, que fora acatada por alguns membros da comissão após encontros com representantes do poder público:

Entendo que num espaço público existe o perigo de o cara que não sabe andar se machucar e prejudicar um monte de outras coisas que estão envolvidas. Mas a realidade da história do nosso esporte é: não se usa capacete. A menos que seja num half pipe a 4 metros de altura, ou num mini ramp dos nervosos. (...) Mas obrigar o uso do capacete, eu acho uma decisão muito elitista. Primeiro, porque uns não têm. "Ah, mas a gente vai disponibilizar lá alguns capacetes". Quantos? Vai disponibilizar 100 capacetes? Vai controlar 100 capacetes? Aí um cara, que inclusive é meu amigo, vira e fala: "mas tem pista de skate em toda periferia. Por que o cara não vai andar lá perto da casa dele?". (...) Isto é segregação! Então o cara que nasce no Jardim Ângela só pode conviver com os que nasceram no Jardim Ângela? Ele não pode andar do lado da MTV? Ele não pode andar na Avenida que é continuação da Avenida Paulista? Ele não pode andar onde um ônibus lotado pára e tem um monte de gatinha olhando? Ele só pode andar lá onde pára a lotação, e tem que correr, pois vão descer os ladrões? O cara não pode? Ele nasceu numa sociedade de castas? Nasceu pobre, viva pobre, seja pobre o tempo inteiro... (Grifos meus).

Indignado, o mesmo interlocutor ainda trata com ironia os próprios skatistas que tentam coibir o uso de certos espaços por parte de outros praticantes. Ele então cita o seguinte exemplo:

A sociedade é carniceira. Se eu estou de terno e gravata, eu não quero ver estes porras desses moleques com esses carrinhos perigosos porque, afinal de contas, eu estou amarrado até o pescoço, e estes merdas sentindo o vento

\footnotetext{
202 Algumas pistas de skate adotam esta medida: antes da prática, o skatista deve assinar tal termo,
} responsabilizando-se por eventuais lesões sofridas. 
na cara. Agora se eu sou skatista, estou aqui na pista, vou fechar com grade, só entra quem eu quero, só os caras que são meus amigos, cresceram comigo, e que andam no meu bairro.

Observa-se assim que, entre os próprios skatistas, são construídos vários discursos, seguidos por muitas práticas que podem, de acordo com certas situações, se configurarem ambíguas ${ }^{203}$. O caso ocorrido na pista do Sumaré revela também alguns conflitos de interesses no universo do skate, principalmente quando estão envolvidos praticantes de modalidades, gerações e condições sociais divergentes em busca de demandas coletivas.

\subsection{2 - Skate à luz de velas}

A inauguração da pista do Sumaré despertou a minha curiosidade. Durante o trabalho de campo no Circuito Sampa Skate, não eram raros os comentários a respeito desse novo espaço que surgira. Mas no contexto do street skate, muitos dos comentários também eram em tom crítico. Vários skatistas diziam que, no Parque Zilda Natel, a área para a modalidade street skate é pequena, torta e com poucas variações de obstáculos. Ainda assim, ela constitui mais um espaço para a prática localizado em uma região de fácil acesso, onde se podem encontrar outros skatistas.

Após várias indicações, resolvi acompanhar de perto a prática do skate nesta mais nova pista da cidade de São Paulo. As minhas constantes idas se deram em dezembro de 2010. Inicialmente, cheguei sozinho ao local, na expectativa de encontrar alguém que fosse conhecido. Após sair do metrô, caminhei por poucos metros e logo avistei as grades verdes do parque. Ainda era de manhã. O local estava vazio. Em sua parte superior, ninguém jogava basquete. Somente algumas mulheres se exercitavam nos equipamentos de ginástica. Chego à beira de uma imensa escada e, lá de cima, avisto toda a extensão da pista de skate, composta pela mini ramp, rampas de street skate e banks.

$\mathrm{Na}$ primeira visita ao local, havia poucos skatistas na pista, dentre eles Everton "Maninho", considerado por outros um típico "skatista de rua". Tanto é que as

203 Muitos skatistas reivindicam o uso de equipamentos urbanos que não foram planejados tendo em vista a prática do skate. Porém, no espaço próprio para esta prática, ou seja, a pista, muitos deles não permitem que outras práticas diferentes do skate sejam realizadas. Prova disso é que em muitas pistas de skate, os usos de patins e bicicletas são coibidos pelos próprios skatistas. Olic $(2010,51)$ também observou estas produções de fronteiras a outras práticas no contexto espacial de uma pista de skate. 
referências feitas a ele são do tipo "rei da rua" e "streeteiro nato". Além disso, toda esta imagem construída serviu de inspiração para que um artista o fotografasse sentado em uma cadeira, usando uma coroa. Esta foto foi exposta no Espaço Diafra da Mostra Transfer ${ }^{204}$, evento realizado durante o ano 2010 no Pavilhão das Culturas Brasileiras, localizado no Parque do Ibirapuera.

Para minha surpresa, "Maninho" estava ao meu lado. E se não bastasse isto, ele estava em uma pista de skate. Cumprimento este e outros dois skatistas que estavam em sua companhia, sentados à beira da borda do banks. "Maninho" perguntou-me se eu sabia da nova pista que fora recentemente inaugurada em uma cidade do interior de São Paulo. Eu disse que já tinha ouvido falar, embora nunca tivesse ido à mesma. Ele então me relatou a sua visita feita ao local. A partir de sua descrição detalhada fui informado de quais skatistas estiveram na inauguração, quais as principais manobras mandadas por cada um, as características dos obstáculos etc. Após isso, "Maninho" voltou a andar na área de street skate. Como fazia muito calor no momento, o skatista estava bem à vontade, andando sem camisa, de cueca samba-canção e tênis.

Chegada a hora do almoço, quase todos os poucos skatistas que estavam no local foram embora. Resolvi ir também. Mas antes combinei de encontrar Everton "Maninho" novamente na pista, para uma eventual entrevista. Ele topou e disse que estava sempre "colando" nela em dias de semana.

Em uma terça-feira, novamente na parte da manhã, retorno à pista na expectativa de encontrar "Maninho", que não estava lá. Ainda assim, a pista estava mais cheia que em minha última visita. Aproveitei para observar os acontecimentos. Enquanto poucos skatistas descansavam nos bancos ou na arquibancada, a maioria andava, principalmente, na área de street skate. Não havia ninguém na mini ramp. No banks, um ou outro praticante se aventurava a dominar as curvas inclinadas da rampa, que mais parece uma piscina aos moldes californianos ${ }^{205}$.

\footnotetext{
204 A Mostra Transfer teve como foco diversos tipos de artes urbanas, manifestas por meio de grafites, fanzines, shapes de skate, fotografias, vídeos, esculturas, entre outras criações. A foto de Everton "Maninho" foi exposta em um espaço ao lado de outras fotos de skatistas.

205 Enquanto a maioria das piscinas de nosso país é retangular e com as paredes retas, na Califórnia (Estados Unidos), ao contrário, elas geralmente possuem formato oval e paredes onduladas. Brandão (2006, 49), ao analisar aspectos históricos em torno do surgimento do skate, aponta a importância dessas piscinas para a consolidação de algumas modalidades: "na Califórnia, a quase totalidade das piscinas existentes possui formato oval, redondo... as paredes possuem transições, que lembram as ondas do mar, com ondulações simétricas e perfeitas. Foi esta graduação nas paredes, somada à habilidade e à técnica dos skatistas de 'Dogtown', sobretudo os da equipe 'Z-Boys', que forneceram às piscinas vazias uma outra utilidade nunca antes pensada: elas viraram as primeiras pistas de skate vertical".
} 
Quase todos os skatistas presentes naquele instante eram crianças ou adolescentes. Havia algumas mulheres os acompanhando, provavelmente suas respectivas mães. Enquanto os garotos andavam de skate ${ }^{206}$, elas os esperavam sentadas em um banco em frente à pista, lendo revistas ou simplesmente observando.

Os objetivos no momento em que se anda de skate na pista são estabelecidos pelos próprios skatistas. Embora seja uma meta individual, há condutas que devem ser seguidas levando em conta uma postura coletiva, essencial para o acontecimento de uma boa sessão. Portanto, como observado, os skatistas seguiam uma ordem de partida aos obstáculos, que era adotada por quase todos. Aqueles que não a seguiam, geralmente atrapalhavam os outros. Tal ato é nomeado de "tesourar", e se dá no instante em que um skatista entra repentinamente na frente do outro para mandar sua manobra. "Tesourar" é um dos atos mais repudiados em uma sessão de skate. Em função disso, até mesmo os skatistas que iniciaram a prática há pouco tempo, aprendem o código primordial logo em suas primeiras idas à pista de skate.

Entre uma manobra e outra, os skatistas estabeleciam diálogos, zombavam daqueles que estavam próximos ${ }^{207}$, ou simplesmente, concentravam-se e observavam os outros. Observavam para serem observados. Através de olhares recíprocos a sessão de skate ganha sentido. E assim como no Circuito Sampa Skate, as boas manobras acertadas eram reverenciadas através de cumprimentos e, também do "yeah!" 208 , expressão de exaltação do nível técnico do outro.

Em um dado momento um skatista desequilibrou-se. O seu skate "espirrou", ou seja, saiu de seu controle, e acertou a canela de outro. Enquanto o skatista machucado gritava de dor, aquele que o acertou rapidamente foi pedir desculpas e perguntar se estava tudo bem. Pelo visto, a dor foi momentânea. Pouco tempo após o ocorrido foi possível observar o skatista que tinha se machucado andando normalmente na pista. Nessa e noutras situações em que o praticante prejudica o outro, o pedido de desculpas deve ser instantâneo, a fim de zelar pela cordialidade estabelecida.

\footnotetext{
206 É válido apontar que esses skatistas estavam vestidos com roupas que fazem referências aos códigos compartilhados, expressos por meio das marcas que as distinguem.

207 Certos tombos sofridos são motivos de risadas. Porém, nem todos, somente aqueles em que o skatista se desequilibra de forma desajeitada e não sofre nenhum tipo de lesão.

208 Compartilho da idéia de Olic $(2010,81)$ que considera que no momento em que um skatista desfere um “yeah!", ele "representa uma ação em que o outro torna-se um afim, indica humildade. Dessa forma, quando um skatista utiliza este termo para com seu outro afim, ele está demonstrando uma abertura às relações de troca, em que ora ele é o sujeito da observação (emite o yeah!), ora ele é o sujeito da ação (recebe o yeah!)".
} 
A parte da manhã nesta pista pesquisada é marcada pela presença dos skatistas mais inexperientes. Dessa maneira, há um aprendizado conjunto daqueles que estão em uma condição técnica parecida. Observei que muitos praticantes tentavam quase sempre a mesma manobra, no intuito de aperfeiçoar aquilo que os skatistas chamam de base, ou seja, as manobras mais simples que condicionam o exercício daquelas mais complexas. É importante pontuar que a pista de skate é um dos espaços onde se aprende boa parte das técnicas e onde os praticantes encontram mais facilidade para o aprendizado, fruto da observação e repetição da técnica empregada pelos outros com os quais se compartilha a sessão.

Próximo a um obstáculo estava um jovem, com aparência de pouco mais de vinte anos de idade. Ele disse morar no Centro e trabalhar no bairro do Sumaré. Por conta da proximidade do parque com seu trabalho, o skatista relatou que sempre aproveita alguns momentos do dia para fazer uma sessão. Com o pé machucado, resolveu parar de andar de skate por alguns instantes. Há algum tempo ele fazia tratamento à base de gelo, porém, como não agüentava ficar sem andar, o machucado nunca melhorava. Conversamos sobre vários assuntos. Um dos rolamentos de seu skate havia estourado. Como não tinha um de reserva, outro garoto deu-lhe um rolamento. Após isso ele me contou que sempre carrega consigo rolamentos reservas, entretanto, alguém os havia furtado em sua mochila. O skatista disse desconfiar da pessoa que o furtou, e também me alertou sobre os cuidados que se deve tomar no momento de deixar as mochilas em certos locais.

Outra ida à pista do Sumaré se deu em companhia do skatista e fotógrafo Marcelo "Mug”, dessa vez no fim da tarde, já quase de noite. Ao contrário do que percebi em outras visitas, o local encontrava-se lotado. Após chegarmos, "Mug" foi ao banheiro. Mas antes disso, deixou sua mochila em um canto qualquer. Perguntei a ele se não havia problema deixá-la ali. A resposta, ao contrário daquela que recebi dias atrás, foi em tom negativo: "é de boa, todo mundo deixa as mochilas aqui. Não tem problema algum", disse-me.

Neste período do dia, a mini ramp e o banks estavam repletos de praticantes. O perfil dos skatistas dessas modalidades é de pessoas mais velhas ${ }^{209}$, que praticam o skate há mais tempo. Logo, como se verificou, muitos destes trabalham durante o dia e aproveitam a folga após o fim do expediente para andarem de skate. A pista estava bem

209 Conforme averiguado na Pista do Sumaré, boa parte dos skatistas da modalidade banks e mini ramp possuem variação de idade entre 25 e 45 anos. 
cheia, porém agora, não só de crianças e adolescentes, mas também de jovens e adultos que dividiam o mesmo espaço para suas respectivas sessões. No entanto, notei uma divisão simbólica na pista, conforme a geração de cada praticante: na área de street skate, a predominância era de crianças e adolescentes; já no banks e na mini ramp, de jovens e adultos. Com efeito, de acordo com a geração também são criados códigos que orientam formas de sociabilidade entre os skatistas ${ }^{210}$.

Na pista de street skate, alguns garotos usavam camisetas semelhantes. Todos eles pareciam ter fortes vínculos de amizade. Ao prestar atenção nos mesmos, reparei que eles portavam também, além da camiseta, skates com adesivos de um mesmo símbolo. Soube então que tais garotos fazem parte de uma crew, chamada "Smith Grinders" ${ }^{211}$, formada somente por skatistas da categoria mirim. Eles sempre andam juntos, embora na companhia do pai de um deles, que freqüentemente os leva para as sessões de skate, seja nas ruas ou nas pistas.

Acima de uma das rampas da área de street skate havia dois cones, colocados pelos próprios skatistas. A idéia era, a partir desses obstáculos improvisados, cada um pulá-los com suas respectivas manobras. De certa forma estabeleceu-se uma espécie de competição, em que eles tentavam realizar a melhor manobra. De repente, um dos seguranças do parque desceu as escadas e foi em direção aos cones. Sem nenhuma explicação, ele os retirou da pista, deixando alguns skatistas indignados com seu ato. Fiquei sem entender o porquê disto. Então pedi explicações a "Mug", que me disse que na pista, em tese, não pode haver nenhum tipo de obstáculo improvisado, a não ser os que já estão ali. Ele acha "totalmente ridícula" essa situação, tendo em vista que uma das principais características da prática do street skate é a improvisação de obstáculos, a fim de tornar a sessão mais criativa e inusitada ${ }^{212}$. Olic $(2010,46)$, ao analisar a prática

\footnotetext{
${ }^{210}$ Embora as diferenças em termos geracionais, percebi que muitos skatistas de gerações diferentes também se relacionam. Essas relações se dão em função da própria prática, a qual motiva os assuntos das conversas. Além de tudo há momentos de respeito mútuo entre adultos e crianças. Um outro fato que me chamou a atenção foi a presença de certos pais que andam de skate juntos de seus filhos. Esta é, portanto, outra diferença se comparada a outros períodos: enquanto de manhã há a predominância de mulheres acompanhando os filhos, à noite, são os homens.

${ }^{211}$ Para mais informações sobre esta crew: http://www.smithgrinders.com.br/.

212 Olic $(2010,46)$, ao analisar a prática do skate em uma pista localizada no CEU Butantã (Zona Oeste de São Paulo), observa que obstáculos improvisados são constantemente utilizados pelos skatistas, ao contrário do que ocorre na Pista do Sumaré: "o espaço conta ainda com alguns obstáculos improvisados, feitos artesanalmente pelos skatistas locais, como rampas, caixotes e traves. A improvisação ocorre também, quando os skatistas se apropriam de objetos - que a princípio não tem nenhuma relação direta com o skate (como, por exemplo, latas de lixo e cones de trânsito) - e passam a incorporá-los ao espaço da pista, onde se metamorfoseiam em obstáculos para a prática do skate". Saliento que tanto o CEU Butantã quanto a Pista do Sumaré são espaços públicos e contam com a presença de seguranças, embora a atuação desses em cada um dos espaços seja diferente.
} 
do skate em uma pista localizada no CEU Butantã (Zona Oeste de São Paulo), observa que obstáculos improvisados são constantemente utilizados pelos skatistas, ao contrário do que ocorre no Sumaré:

O espaço conta ainda com alguns obstáculos improvisados, feitos artesanalmente pelos skatistas locais, como rampas, caixotes e traves. A improvisação ocorre também, quando os skatistas se apropriam de objetos que a princípio não tem nenhuma relação direta com o skate (como, por exemplo, latas de lixo e cones de trânsito) - e passam a incorporá-los ao espaço da pista, onde se metamorfoseiam em obstáculos para a prática do skate.

Saliento que tanto o CEU Butantã quanto a pista do Sumaré são espaços públicos e contam com a presença de seguranças, embora a atuação desses em cada um dos espaços seja diferente. "Mug" disse ainda ter contestado a norma inúmeras vezes. Em algumas ocasiões, chegou a colocar os cones novamente no mesmo local e a incentivar os garotos a voltarem a andar. Porém, segundo ele, a "molecada", isto é, os skatistas mais novos, ficam com medo de uma possível repressão por parte dos seguranças e acatam as ordens. Para esse skatista, essa série de regras é uma das desvantagens em andar na pista do Sumaré.

O horário de funcionamento do parque é das $9 \mathrm{~h}$ às $21 \mathrm{~h}$. Contudo, o mesmo não estava sendo seguido à risca, devido a problemas com a iluminação do local, que se agravavam há mais de um mês. Diante disso, os skatistas eram forçados a ir embora mais cedo, devido à impossibilidade de se praticar no escuro. Revoltados com a situação, alguns procuraram a prefeitura. Como nada foi resolvido, muitos usuários do parque tentaram dar visibilidade ao que ali acontecia. Certo dia, os skatistas levaram velas para o parque. Já de noite, em meio à escuridão, acenderam-nas e andaram de skate mediante as suas luzes. Após fazerem fotos desse ato simbólico, enviaram-nas para alguns veículos de comunicação, como o jornal SPTV da Rede Globo.

Já de noite, os skatistas se preparavam para ir embora. De repente, na saída, uma mulher aproximou-se de Marcelo "Mug", apresentando-se como repórter da Revista Veja São Paulo. Ela queria saber mais informações sobre o protesto feito à luz de velas, e também se havia a possibilidade de repeti-lo para que uma matéria fosse feita para a revista. "Mug" gostou da idéia e chamou Luciano "PT", um dos skatistas que mais freqüenta o parque, para que ele mobilizasse os outros e tentasse fazer novamente o 
protesto. Os skatistas que estavam na pista concordaram e marcaram o ato para o próximo dia, uma sexta-feira, no começo da noite.

No outro dia, novamente na companhia de Marcelo "Mug”, observei que, prestes a escurecer, os obstáculos das três modalidades estavam completamente cheios. Nas arquibancadas e nos bancos vários skatistas também aproveitavam o momento para colocar o papo em dia. "Mug" foi ao encontro do fotógrafo da revista que faria a matéria, o qual já o esperava no local. Eles então combinaram quais fotos poderiam ser feitas, tendo em vista o objetivo dos skatistas.

Enquanto isso, os skatistas continuaram a andar na pista. De repente, ouvi um garoto dizer que a polícia acabara de passar pelo parque, após receber a denúncia de que provavelmente alguém estaria usando drogas no local. Os policiais, assim que chegaram, foram direto ao banks, local em que se reúnem os praticantes de idades mais avançadas, e pressionaram os presentes para averiguar se a denúncia realmente procedia. Não demorou muito e foram embora, sem nenhum flagrante. "Mug" acredita que algum morador da região tenha feito tal denúncia.

Já era de noite. Na mini ramp e na área de street skate não havia mais ninguém. Os skatistas que estavam no local se concentraram em frente ao banks. Um deles perguntou ao outro: “podemos começar?”. Esse respondeu: “vamos nessa!”. Eles então pegaram um banner e o afixaram em uma grade. Aproximei-me para ver do que se tratava. O banner protestava contra a falta de luz na pista, através dos dizeres: "Parque Zilda Natel: 1 mês sem luz. Descaso. Vergonha".

Em seguida, os skatistas tiraram várias velas de dentro de uma mochila. Rapidamente, elas foram distribuídas entre os demais. Concomitante, o fotógrafo preparou seus flashes ao redor do banks. A repórter, a qual estivera no dia anterior, conversava com os skatistas, a fim de entender melhor sobre o problema que acontecia. Alguns deles acreditam veementemente em um descaso por parte do poder público com a prática do skate. Outros ponderam que, caso o parque fosse usado por algum morador "rico" e influente da região, o problema já teria se resolvido.

Com as velas acesas em mãos, os skatistas se preparavam para as fotos. Para a primeira delas, todos entraram no banks e ficaram em pé. Na frente, os skatistas mais novos; atrás, os adultos. Em seguida, todos sentaram na borda da rampa, formando um grande círculo. Assim, foi feita a segunda foto. Por fim, para a última foto, alguns presentes ficaram em pé com as velas no centro do banks, enquanto Rogério "Troy", skatista profissional, realizava uma manobra em torno deles. Ao final das fotos todos 
assobiaram e gritaram frases como "skate or die" e "skate is my life" 213 . Com o fechamento do parque, alguns dos streeteiros presentes resolveram dar continuidade à sessão de skate. Dessa vez, porém, foram para as ruas, ou melhor, para a Avenida Paulista, para aproveitar os picos por ela oferecidos.

Anteriormente, foram apresentadas certas divergências entre skatistas de modalidades e gerações diferentes devido ao uso do capacete na pista. Neste tópico em específico, ao contrário, é possível notar a partir deste ato simbólico, as articulações feitas entre muitos em prol de melhorias para o espaço onde se pratica o skate. Até mesmo os streeteiros, que andam ocasionalmente na pista do Sumaré, participaram da manifestação, de cunho político.

\section{3 - A cidade vista através do olhar skatista}

Conforme visto até aqui, os skatistas da modalidade street skate, sempre que podem, procuram andar em pistas. Afinal, é nelas que se encontram, entre outras coisas, tipos de obstáculos parecidos com aqueles disponíveis em competições como o Circuito Sampa Skate ${ }^{214}$. No entanto, o que se tenta evitar é a prática somente em uma única pista. Caso isso aconteça, corre-se o risco do skatista ser tachado de pistoleiro, tal como apresentado no início deste capítulo.

No contato com o universo do street skate paulistano, fica evidente que a prática do skate nas ruas está no centro das atenções dos interlocutores. Com efeito, as experiências vividas nelas são bem diferentes - e também, mais valorizadas - que aquelas vivenciadas nas pistas. É nas ruas, como dizem os próprios skatistas, que se experimenta o "verdadeiro" skate. Até aqui muito se falou das importâncias das "ruas" para os skatistas. Mas o que, de fato, interessam-lhes nas mesmas? ${ }^{215}$

Para a maioria dos paulistanos, o termo "pico" pode fazer referência a uma situação intensa e conturbada (por exemplo, o horário de "pico" no trânsito). Já para os

\footnotetext{
213 Em português, essas expressões são ditas pelos skatistas como: "ande de skate ou morra" e "skate é a minha vida".

214 É importante salientar que as pistas da modalidade street skate não são padronizadas. Cada uma pode conter diferentes tipos de obstáculos.

215 Destarte, as referências feitas às "ruas" nesta pesquisa não levam tanto em conta a função tradicional de espaço destinado ao fluxo, mas sim, as apropriações e atribuições de sentidos por parte dos citadinos pesquisados. Portanto, reitero que "andar de skate nas ruas" não significa dizer unicamente que os skatistas circulam no asfalto entre automóveis. Ao contrário, o sentido atribuído à prática do "skate nas ruas" se dá a partir das experiências em torno da utilização dos picos, termo nativo discutido ao longo de todo este capítulo.
} 
skatistas, pico é um termo nativo que evoca espaços compostos por equipamentos urbanos, que se tornam obstáculos nos quais são realizadas as manobras. Também definido pelos skatistas como lugares skatáveis, para que um equipamento seja considerado um pico, ele deve estar associado a uma série de características que permita a prática do skate.

As características ideais atribuídas a um pico são basicamente três, abaixo citadas: ${ }^{216}$

Chão da ida: é o espaço a partir do qual o skatista toma impulso para ir em direção ao obstáculo. O melhor tipo de chão é o de superfície lisa, a qual não permite tanto atrito com as rodas. Nela o skate se locomove com maior facilidade, possibilitando a realização de manobras no obstáculo a ser utilizado.

Obstáculos: são os equipamentos urbanos onde os skatistas executam as manobras. Os obstáculos são das mais variadas formas. Alguns deles são nomeados pelos skatistas de uma maneira diferente daquela originalmente atribuída por quem os construiu. Desse modo, uma parede pode ser vista como um wallride; um pedaço de ferro torto fixado no chão como um pole jam; um barranco como um gap, e assim por diante.

Além disso, o olhar dos skatistas para os equipamentos urbanos é tão preciso que eles se atentam aos tamanhos e aos tipos de materiais que são feitos. Um exemplo são as escadarias em que há particularidades. Algumas contam somente com os degraus; mas também há a double set (duas seções de degraus) e a triple set (três seções de degraus). O corrimão de uma escada pode ser quadrado ou redondo, com tranco ou sem tranco, inclinado ou "suave". As bordas de um banco podem ser de concreto, de mármore, de madeira, de ferro ou outros materiais. Portanto, antes de andar em um obstáculo, os skatistas examinam todas as suas características e, com base nelas, realizam algum tipo de manobra, com maior ou menor técnica, com riscos de tombos ou com maior domínio sobre o skate.

Chão da volta: assim como o chão da ida, é o espaço em que o skatista permanece após mandar a manobra no obstáculo. Quanto mais amplo e liso, melhor será, pois a manobra poderá ser completada com mais eficiência.

Um pico perfeito para os skatistas é aquele que conta com o chão da ida e da volta com um considerável espaço de superfície plana e lisa, propícia para pegar impulso, e

216 Contudo, nem todos os picos possuem estas características. Por exemplo, o solo geralmente não possui obstáculos, somente o chão liso. 
também, com um obstáculo feito de materiais que possibilitem boas condições de se mandar uma manobra, como, por exemplo, um banco de mármore ${ }^{217}$ ou um corrimão sem travas ${ }^{218}$.

Achar um lugar skatável nesses moldes é o objetivo de qualquer streeteiro. Contudo, como será apresentado nos próximos tópicos, encontrar o pico perfeito não é tão fácil como se imagina. Desse modo, diante da busca incessante por espaços que permitam a prática do street skate, é preciso saber "ler" a cidade de uma forma diferenciada da usual:

[A prática do street skate] é tipo começar a ler um livro, onde você vai descobrindo, vai entrando cada vez mais nele e trocando idéia com a rua, vendo que tem muita coisa que você pode fazer. Na rua tem bastante opção para você ir cada vez mais procurando outros lugares (Rodrigo "Bocão", entrevista em 17 de março de 2010, grifos meus).

Tornar-se streeteiro implica em tornar-se "leitor" de picos ${ }^{219}$. A possibilidade dessa "leitura" feita na cidade é algo que instiga e incentiva os citadinos a irem cada vez mais para as ruas, em busca da descoberta de espaços antes nunca usados para a prática do skate. Porém, para que a mesma seja feita, é preciso construir aquilo que alguns chamam de olhar skatista:

Eu pego ônibus ou até mesmo metrô, e vou vendo aquele pico que talvez dê para andar, se arrumaram a calçada e se agora dá para andar. Desço com minha namorada de carro e ela racha o bico: "meu, eu fico vendo as coisas bonitas e você fica vendo se dá para andar de skate!". Olho de skatista é para olhar a arquitetura da cidade, para ver se dá para rolar skate (Alexandre "Nicolau”, entrevista em 26 de março de 2010).

Eu ando muito de carro. Eu moro na Zona Sul, faço faculdade na Zona Leste. Então tenho que ir até a Radial Leste. Eu passo por muitos lugares. $E$ uma vez skatista, sempre skatista! [Você] nunca mais enxerga a cidade como qualquer outra pessoa. Mesmo que você nem ande mais de skate,

\footnotetext{
217 Segundos os interlocutores, os obstáculos feitos em mármore são os prediletos dos streeteiros. Esse tipo de material faz com que o skate deslize com maior facilidade.

${ }^{218}$ Essas afirmações são feitas com base na fala dos próprios skatistas.

${ }^{219}$ Com efeito, para Joseph $(1999,34)$, a etnografia de um lugar público é, necessariamente, a etnografia de um espaço de comunicação, como este encontrado no contexto urbano pesquisado. Portanto, não se pode ignorar as formas de adaptação do olhar nem a percepção do ambiente por parte dos streeteiros.
} 
você vai ficar olhando para os picos, para a rua, procurando alguma rampa para falar: "ali dá para mandar tal manobra!". Isso é um "bagulho" que é verdade. Tinha até um anúncio da DC Shoes das antigas que falava isto: "uma vez skatista, sempre skatista”. Você nunca mais enxerga a rua normal! (Caio Youssef, entrevista em 15 de abril de 2010, grifos meus).

A cada ano [de prática] que passa, o skatista adquire mais a visão. E tem vez que isto é até meio chato. Porque você não consegue andar na rua tranqüilamente, pois todo pico que você vê, você já comenta. E às vezes, quem está ao seu lado, não entende porra nenhuma do que você está falando (Victor Ferrari, entrevista em 16 de abril de 2010, grifo meu).

Você sai passeando com sua namorada, de mão dada com a mina, segurando a mão dela e olhando para os lugares. E no outro dia você encontra [os outros skatistas] para a sessão e: "vi um pico ali, estava indo no cinema com minha mina, e vi um pico da hora que dá para andar. Vai lá e tenta ver". Skatista consegue analisar até pedra portuguesa, quando a pedra portuguesa é muito irregular ou quando ela é mais retinha e dá para o skate andar. (Tiago Garcia, entrevista em 13 de abril de 2010, grifos meus).

Outra coisa engraçada também, mas também é normal: você sabe o asfalto da cidade, os caminhos que você sempre passa, você já sabe: aquela faixa, aquela rua. Inconscientemente você já sabe o caminho para o skate andar. Você nem pára para pensar, mas já sabe (Fábio Brandão, entrevista em 13 de abril de 2010).

A partir desse olhar, certos skatistas disseram ter tentado até catalogar alguns picos encontrados durante os seus respectivos trajetos pela cidade, o que facilitaria a seleção dos melhores lugares para fazer uma eventual sessão de skate:

Às vezes eu via um pico maior legal. Então eu descia do ônibus para ver o pico, anotava o nome da rua e o número aproximado de onde fica, e depois voltava lá para andar de skate e filmar. Eu faço isto até hoje, e até passo para os outros. De ver o pico, de escrever: "bordas de três degraus e dá para fazer este tipo de manobra para quem é esquerdo ou direito" (Jorge Costa, entrevista em 19 de março de 2010, grifos meus)

De certa forma, a possibilidade do encontro inesperado e da conquista de um pico é um dos grandes atrativos da prática do skate nas ruas, o que constitui um diferencial 
em relação às pistas, já que nelas os aspectos apresentados não constituem algo a ser superado. Nos picos, por mais que um skatista realize uma mesma manobra, o cenário com o qual ele interage será diferente. Portanto, as sensações experimentadas nas ruas são diversas:

Se você andar sempre no mesmo lugar, você entra numa monotonia. No street, por mais que você ache um pico novo e mande uma mesma manobra, é outra coisa. Por exemplo: eu achei uma borda $x$, fui lá e mandei um tailslide. Daí eu achei outra borda, com umas características diferentes, e mandei um tailslide também. É a mesma manobra, mas já é algo diferente. Você sempre busca uma coisa nova. Por isso que tem tanto cara querendo andar lá fora [do país]. São muitos picos diferentes. Os caras mandam as mesmas manobras que mandam aqui. Mas o pico é que faz a diferença. É onde você está andando (Raphael "Pezão", entrevista em 29 de março de 2010).

Outro elemento lúdico da prática do street skate é justamente a procura por picos. Logo, sempre que possível, é importante circular por vários desses espaços. Entretanto, a procura por lugares skatáveis não se dá somente ao acaso. Ciente de suas habilidades em cima do "carrinho", os skatistas vão ao encontro daqueles obstáculos com os quais mais se identificam:

Têm quatro, cinco dentro do carro, e aí cada um vai olhando. A gente olha se o pico é legal para andar de skate, se o chão é bom, se é skatável. Se é uma borda, um gap, uma escada. Por exemplo, se é uma escada e dá para andar mesmo. Ou se é só uma escada que não leva a nada, que não tem saída, não tem entrada, não tem de onde você vir. E também, se pode andar de skate (...). A gente olha o pico, dependendo da galera que a gente anda. A maioria dos moleques que a gente anda gosta mais de andar em borda, em escadas mais baixas. Só o Léo, esse amigo meu, que desce corrimão, desce escada. Daí quando a gente saí com ele, ele fica prestando atenção em umas escadas maiores, em um corrimão maior (Raphael "Pezão", entrevista em 29 de março de 2010).

É possível encontrar picos em qualquer região de São Paulo. Nessa busca, a circulação de skatistas pela cidade progride conforme novas sessões são feitas ${ }^{220}$. Elas

220 A progressão dessa circulação tem como ponto de referência o local de residência de cada skatista. 
possibilitam também o alargamento da sociabilidade tecida entre os que se encontram durante a prática. Assim, a busca por espaços também torna dinâmicos os relacionamentos entre os skatistas.

Alguns picos situados em regiões mais centrais da cidade possuem importância especial. Embora quase todos os praticantes residam longe deles, lá é que eles se encontram, como é o caso do Vale do Anhangabaú e do Parque do Ibirapuera, pontos de referência, onde muitas redes se cruzam. Levado pelos próprios skatistas, tive a chance de acompanhá-los em diversas sessões nestes espaços.

\section{4 - Quando os “carrinhos" vão ao Centro}

As lógicas atribuídas à prática do street skate por parte dos skatistas possuem certos distanciamentos em relação àquelas atribuídas pelo poder público. Enquanto os últimos priorizaram, ao longo do tempo, a construção de pistas e a promoção de eventos em bairros periféricos, para os primeiros, ao contrário, muitas das experiências socialmente valorizadas e compartilhadas decorrem em equipamentos urbanos, situados em regiões mais centrais da cidade. Entretanto, apesar das distâncias, essas lógicas também possuem continuidades. Os skatistas - ou para ser mais específico, os streeteiros -, aproveitam-se das pistas e picos situados próximos de suas residências, embora também não deixem de buscar a prática em locais bem mais longínquos, mesmo que isto implique em horas dentro de um transporte público em meio ao conturbado trânsito de São Paulo.

Após tantas idas a campo é possível dizer com segurança que o centro de São Paulo é notadamente importante na história e no atual contexto da modalidade street skate. É para lá que se dirigem skatistas de todas as partes da cidade, do estado, do país e até do mundo. Ir ao Centro não implica somente em andar de skate ou em aperfeiçoar o desempenho técnico das manobras. As motivações também são outras, muito além daquelas relacionadas a uma prática esportiva. Com efeito, a pluralidade de sensações e experiências vivenciadas constitui um dos principais atrativos para que os praticantes permaneçam horas e horas na região. Nesse sentido, pretende-se evidenciar, com base em discursos e práticas, a relevância do centro de São Paulo para os streeteiros.

\subsection{1 - Por que o Centro?}


A prática do street skate no centro de São Paulo não data desta década. Basta conversar com streeteiros mais velhos ou pesquisar em revistas antigas para perceber que, desde final dos anos 1980, essa região serve de palco para inúmeras sessões. Nessa época os skatistas se reuniam em lugares como a Estação São Bento do metrô, a Praça Roosevelt e o Viaduto Santa Ifigênia. Tempos mais tarde esses espaços perderam parte de suas importâncias para os streeteiros devido, em certa medida, à revitalização de um lugar antes nunca imaginado para a prática do skate: o Vale do Anhangabaú. Antes mesmo de sua reinauguração, no começo da década de 1990, alguns skatistas, ao passarem pelo Viaduto do Chá, observaram que o local possivelmente seria um bom pico para se fazer uma sessão. Sem pensar muito, após esperarem a saída das máquinas e funcionários, eles pularam os tapumes e foram ao encontro das muitas bordas de concreto ali contidas ${ }^{221}$.

Desde então, muitas outras coisas aconteceram. O "Vale", como é chamado pelos skatistas, tornou-se o principal pico para a prática do street skate na cidade de São Paulo. A importância é tanta que, conforme relato de alguns streeteiros, esse local é uma espécie de cartão postal ou ponto turístico do skate, tendo em vista os inúmeros skatistas que o visitam:

O legal do "Vale" é que você encontra gente de várias partes do Brasil, meio que fazem um turismo no Anhangabaú; e muitos gringos de fora também. Vários gringos vão lá para conhecer o Anhangabaú e filmar. Eu vi esses dias lá o Anthony Claravall ${ }^{222}$, e um suíço, da Cesar Prod ${ }^{223}$. (...) Ali é um ponto de encontro, porque ninguém mora no Centro. As pessoas moram longe umas das outras e vão ali para se encontrar. Ou então, de lá vão para outros lugares para andar de skate, filmar e fotografar. O "Vale" é um ponto de encontro, e rola um "caixa dois", como se diz no mundo do skate. Geralmente você vende umas peças de skate lá e meio que faz um dinheiro (Jorge Costa, entrevista em 19 de março de 2010).

Como se pode observar, aproveitando-se do fluxo de skatistas pelo local, alguns freqüentadores fazem um "caixa dois", prática de compra e venda de produtos novos ou

\footnotetext{
${ }^{221}$ Alguns skatistas me contaram este fato. Após um tempo confirmei a veracidade do mesmo, através de uma matéria publicada pela Revista CemporcentoSkate (edição 12, fevereiro de 2010), intitulada "10 coisas que você deveria saber sobre o Vale do Anhangabaú". Marcelo Barneiro, Alexandre "ZikkZira", Daniel "Trigo", Ricardo "Pingüim", Edu Fernandes e David Toledo são tidos como alguns dos streeteiros pioneiros no Vale do Anhangabaú.

${ }_{222}$ Skatista e videomaker norte-americano.

${ }^{223}$ Trata-se do suíço Tristan Zumbach, responsável pela produtora de vídeos de skate Cesar Prod.
} 
usados diretamente com os donos. Certos freqüentadores do "Vale" são, além de skatistas, empresários do ramo do skate. Enquanto responsáveis por algumas marcas, eles geralmente vendem produtos com preços mais em conta que nas lojas.

Equipamentos urbanos - ou picos, para ser mais preciso - é o que não faltam em toda a extensão do "Vale". É possível encontrar muitos obstáculos, de vários tipos. Diante de tamanha diversidade, os skatistas atribuem certos nomes aos equipamentos, dando novo significado a cada um deles, com base em suas características:

Na real, ali tem uma variedade. Tem um espaço bem grande. Um local onde você pode ficar sentado, tomar uma água, tem bastante opção para andar de skate. Tem o gap que você pode andar, que é o canteiro; tem o big two; tem o pedacinho lá, que é o manual grande e o menor; uma borda para você andar pra lá e pra cá. Só aquela ali né, que é os “caminhos de ratos" que o pessoal fala. Tem as pedras portuguesas que você tem que andar desviando. Mas se você for andar nas pedras, tem que andar desviando. Tem o pessoal que reclama, que a borda não escorrega, que é estranho. É costume, né. Você vai começar andar e vai ver que dá pra acostumar (Rodrigo "Bocão", entrevista em 17 de março de 2010).

A maioria desses obstáculos fica nas arquibancadas de concreto, onde os skatistas se reúnem para a prática. De um ponto de vista técnico, de acordo com os interlocutores desta pesquisa, andar de skate nos picos do Vale do Anhangabaú é extremamente difícil, devido, basicamente, a dois fatores: ao chão de pedra portuguesa que dificulta a locomoção com o skate e as bordas ásperas de concreto. Diante essas dificuldades, alguns streeteiros acreditam que aqueles que conseguem dominar os obstáculos do "Vale", certamente conseguirão dominar aqueles de qualquer outro pico:

É um pico legal, bonito, com a arquitetura bonita. É o verdadeiro street. Pedra rústica. Tem toda opção aí de gap, corrimão, bordas descendo que fazem parte também, as pedras para você fazer manual. Acredito que o que você desenvolver aqui, você consegue levar para qualquer lugar. Pista, qualquer lugar. Se você tiver base de andar numa rampa vertical, andar no copping block. Você já tem a noção do que é escorregar o eixo numa pedra ou numa bordinha de ferro. Tem os caminhos aqui onde a gente anda, consegue acertar as manobras retinhas. Não saí umas manobras tortas (Alexandre "Nicolau", entrevista em 26 de março de 2010, grifos meus). 
Todo grande centro tem muita construção, tipo monumento, coisas de mármore. Então todo centro, por ser bem urbano, tem este estereótipo. A gente explora isto. $\mathrm{O}$ que eu acho legal do street é usar o que já foi feito para criar em cima disso e andar de skate. Aqui vem galera do mundo todo. $\mathrm{O}$ "Vale", no caso, é um lugar muito difícil de andar. Se você fica uma semana sem andar, quando volta, dá uma "sofridinha". Eu imagino quem é de fora. Muita galera vem de fora e fica vendo a gente andar. Fica sentado, nem anda de skate. Tenta andar, não consegue, aí sai fora. É um lugar difícil de andar. Você tem que ter muita criatividade para explorar as coisas que ainda não foram feitas. Aqui tem tudo: tem manual, tem gap, tem borda. Se você explorar, dá para usar tudo isso de uma vez só. Então esta é a grande dificuldade do "Vale". A galera vê a gente andando e acha que é muito fácil. Aí quando você vai andar mesmo, você vê que não é tão fácil assim (Sandro Sobral, entrevista em 31 de março de 2010).

Levando em conta tais falas, portanto, os skatistas que possuem pouco tempo de prática e pouca habilidade com as manobras, provavelmente não conseguirão andar de skate no "Vale" ${ }^{224}$. Alguns interlocutores me disseram que, quando se inicia a prática do skate, tende-se a andar e a se relacionar com outros praticantes somente em locais próximos de sua residência. Porém, conforme o aprendizado, o skatista se torna apto a encarar uma variedade de obstáculos com os mais diferentes graus de dificuldade, e com isso, passa a desbravar lugares skatáveis longes dali.

Ao contrário do que acontece em muitos outros picos encontrados na cidade, no Vale do Anhangabaú não há tanta repressão, por parte de seguranças e policiais, com relação à prática do skate em equipamentos urbanos ${ }^{225}$. Por outro lado, as repressões se voltam para outros tipos de práticas realizadas pelos diferentes atores, que também utilizam esse espaço.

Jorge Costa observa que:

O problema do Anhangabaú é um monte de vagabundo que aparece por lá, que tenta se camuflar entre os skatistas. Aparecem trombadinhas, ladrões que ficam ali tentando se misturar com os skatistas, para disfarçar e fazer

\footnotetext{
${ }^{224}$ Contudo, isto não quer dizer que os principiantes deixem de ir ao Vale do Anhangabaú.

225 A única repressão que tomou maior visibilidade se deu por volta do ano 2000: "na virada do século, o Bank of Boston assumiu temporariamente a manutenção e conservação dos degraus. Durante alguns meses, enormes seguranças, trajando ternos pretos, ficavam postados em diversos pontos, mesmo debaixo do sol intenso, impedindo qualquer tentativa de sessão no local. Foi a única época em que o skate foi proibido no Anhangabaú” (Revista CemporcentoSkate, edição 12, fevereiro de 2010).
} 
novas vítimas. O problema do Anhangabaú também é que lá tem uma energia muito pesada. Lá eu acho que era um cemitério indígena. Então é um lugar muito carregado. Tem um monte de bêbado, muita gente fuma maconha, não só quem anda de skate. Quem anda de skate é a minoria. É impressionante a galera que sai dos prédios lá, saem na hora do almoço e ficam fumando uma no meio do "Vale". E tem uns moleques que aparecem lá, que fica cheirando cola. Isso também é uma coisa muito ruim de se ver. Sem dizer aqueles bêbados que ficam lá o dia inteiro na grama tomando 51 (Entrevista em 19 de março de 2010).

Diante o apresentado, Tiago Garcia considera que o skate é o menor dos "problemas" encontrados no "Vale". Além do mais, segundo ele, o poder público estrategicamente vale-se da prática do skate no local, tendo em vista que ela supostamente repele outros tipos de práticas tidas como ilegais, como o consumo de drogas:

De vez em quando o prefeito resolve falar que não pode [andar de skate no "Vale"]. Um tempo atrás, Kassab [prefeito da cidade] falou que não podia. Aí ele começou a prestar atenção que aonde tem cara andando de skate, não tem muitos caras de rua mesmo. Uma época atrás no "Vale", os caras começaram a mandar embora os caras da cracolândia e os caras começaram a migrar para cá. Aí ficavam os caras fumando pedra, maconha o dia inteiro. E os caras começaram a perceber que onde tem a galera de skate, esses caras não ficam muito perto. Melhor ter skatista que droga. O skate meio que dá uma limpada (Entrevista em 13 de abril de 2010, grifos meus).

A proximidade com estações de metrô e terminais de ônibus possibilita que praticantes de qualquer parte da metrópole tenham fácil acesso ao "Vale". Logo, a sua importância se dá não só pelos inúmeros picos que o compõe, mas também, por ser um espaço significativo de sociabilidade ${ }^{226}$, onde os skatistas se reconhecem como tais ${ }^{227}$,

\footnotetext{
226 Olic $(2010,50)$ considera que nas pistas os skatistas tendem a construir relações de pertencimento ao espaço, constituindo aquilo é chamado pelos praticantes de localismo. Porém, esse autor considera que o localismo se restringe somente às pistas. Nesta pesquisa pretende-se mostrar que o localismo pode ser encontrado não só em pistas, como também, em picos, sobretudo naqueles localizados em regiões centrais da cidade. Em vários tópicos deste capítulo é possível observar discursos dos interlocutores que apontam para a existência de "skatistas locais" em certos picos. Contudo, concordo com Olic (2010, 66) que, embora os skatistas locais tomem como ponto de referência um certo espaço, eles não se restringem ao mesmo.

227 Sobre isso, Tiago Garcia deixa claro: "todo mundo sabe de todo mundo, todo mundo conhece todo mundo. Mas nem todo mundo é amigo de todo mundo" (Entrevista em 13 de abril de 2010). Esses e outros discursos articulam-se com aquilo que Sierra e Mesquita (2009, s/p) nos dizem, ao se referirem as
} 
a partir do compartilhamento de diversos códigos e trocas recíprocas de experiências ${ }^{228}$. Alguns interlocutores expressam suas respectivas opiniões sobre essa questão:

[O "Vale"] não é um ponto de encontro para uma galera só, para um tipo de skate só. Vem gente de todo qualquer lugar. As afinidades são mais pelo skate. Mas no "Vale" não tem só um estilo de skate. Tem gente que anda diferente, tem a galera mais velha, mais nova. O Centro é muito rico em skate (Fábio Brandão, entrevista em 13 de abril de 2010).

O "Vale" é muito importante para o skate. É tipo um marco zero. Pode ver que vem pessoas de outras cidades e até de outros países, aqui é o ponto de encontro: "ah, vamos nos trombar no 'Vale' para a gente ir para a Sé!". "Vamos nos trombar no 'Vale' para gente ir para a Roosevelt". "Vamos se 'trombar' no 'Vale' para ir, de repente, lá na Ultra, no bowl ${ }^{229}$ ". Pessoal que não é de São Paulo de repente costuma marcar aqui, onde todo mundo se encontra para ir para outros lugares (Alexandre "Nicolau", entrevista em 26 de março de 2010).

Com base nas falas desses interlocutores, percebe-se que o Vale do Anhangabaú é um dos pontos de encontro entre os praticantes do street skate, onde se nota a presença de skatistas pelo local em todos os dias e horários possíveis. Devido a essa frequiência regular, alguns skatistas resolveram até criar certas crews de amigos, entre as quais se destaca a KDC (Krew do Centro) ${ }^{230}$, composta por praticantes de várias partes da cidade que se encontram no "Vale".

A partir do "Vale", outros locais do Centro são constantemente freqüentados pelos skatistas. Destacam-se a Praça da Sé e a Praça Roosevelt. Devido à proximidade de uns com os outros, em uma mesma sessão os streeteiros podem utilizar os picos desses espaços mencionados:

O Centro é o foco de tudo, em relação a tudo. É onde todo mundo se encontra, é onde tem o "Vale", a Sé, a Roosevelt, que são lugares onde a

idéias de Isaac Joseph: "o espaço público urbano é um espaço de excesso de sociabilidade, que compreende processos de socialização-dessocialização, mobilidade, mobilização e instabilidade de indivíduos e grupos".

228 Partindo da concepção de Joseph (2005), os espaços públicos - como o Vale do Anhangabaú - são marcados pela acessibilidade, circulação e comunicação, onde práticas relacionadas a vários universos podem se encontrar.

${ }^{229}$ Ultra Skatepark, extinta pista de skate da cidade de São Paulo.

230 A KDC (Krew do Centro) ganhou mais notoriedade a partir de uma matéria especial sobre crews, feita pela Revista Tribo Skate (Edição 179, agosto de 2010). 
galera pode andar normalmente, independente de dia, se é final de semana ou dia de semana. E ao mesmo tempo tem a galeria, que é uma ferramenta fundamental na prática do skate (Tiago Garcia, entrevista em 13 de abril de 2010).

Para mim tem uma opção legal, de ficar ali o dia inteiro andando. Não é um lugar onde você vai só para fazer uma missão para filmar e voltar... É um lugar para o dia a dia. Mas tem esses dias que a gente pega, geralmente nos finais de semana, e vai viajar ou fazer uma sessão em outra região de São Paulo mesmo. O centro de São Paulo a gente já tem ali. Nós temos o "Vale", a gente pode ir à Praça da Sé, pode ir à Roosevelt, pode ir ao Pátio do Colégio fazer um solo e tem ali a Galeria, onde nós passamos e conversamos; tem o Rei do Mate onde a gente toma um mate. Essa coisa do dia a dia, do pessoal estar junto (Rodrigo "Bocão", entrevista em 17 de março de 2010).

Não obstante, streeteiros provenientes de diferentes localidades se encontram no "Vale" e a partir dali circulam por outras regiões da cidade, tendo em vista, sobretudo, a procura por diferentes picos $^{231}$ :

É um lugar que você vai andar de skate, vai trombar seus amigos, vai trocar idéia, vai marcar um "rolê" para o fim de semana. É um ponto de encontro onde você vai todo dia e terá um skatista. Pode ser de madrugada, pode ser de manhã, pode ser andando, pode ser filmando, fotografando. Tem skatista que cola só, para tipo, "ah, vou colar no Centro só para 'trombar' os caras e trocar uma idéia". Tem gente que põe o "Vale"... "ah, vamos andar em tal lugar?" "Que horas a gente se 'tromba'?" "ah, vamos se 'trombar' no 'Vale' 1 hora da tarde". É meio que um ponto de encontro para os skatistas (Rodrigo "Bocão", entrevista em 17 de março de 2010).

\footnotetext{
231 Outros citadinos que se encontram no Centro para compartilhar experiências em virtude de uma prática comum deslocam-se pela cidade de forma parecida com a dos streeteiros. Este é o caso dos pixadores, analisados por Pereira (2007). Na época de sua pesquisa, o local de encontro para pixadores provenientes de várias partes da cidade era o chamado point da Vergueiro. Esse local, segundo o autor, "atrai pixadores de diversas regiões para o Centro; depois, dispersa os pixadores para a periferia, para as diversas 'quebradas', através dos 'rolês' marcados com outros pixadores (...). Sendo assim, primeiro há os trajetos que levam do particularismo dos bairros para a diversidade do centro; em seguida, já no centro, surge a possibilidade de outros trajetos, que levam para outras "quebradas"” (Pereira, 2007, 242- 243). O Vale do Anhagabaú não é classificado como um point pelos streeteiros, porém, as características atribuídas a essa categoria nativa discutida por Pereira (2007) se aproximam daquelas atribuídas aos picos do "Vale", localizados na região central da cidade. Contudo, a diferença é que ao invés de reunirem pixadores, reúnem streeteiros, e estes, ao invés de irem para as "quebradas", vão para outros picos.
} 
Por fim, para dar ênfase à discussão feita sobre a importância do Centro, cabe ainda a citação de trechos de um texto intitulado "Ser do Centro", de autoria de Douglas Prieto, que resume um pouco das experiências vivenciadas nessa região da cidade de São Paulo:

Que cena é essa que rola no Centro de São Paulo? Quanta história já aconteceu nestas ruas, bordas, inclinações? E essas figuras, que estão sempre lá, os que surgem, os que renascem, os que desaparecem? Elementos dessas gangs do bem, quase sempre receptivas, amigos agrupados pra manter viva a essência do skate e o respeito pelo lugar de onde vieram, e que fazem questão de levar pra onde quer que vão. (...) Rodrigo Teixeira ${ }^{232}$, sentindo-se em casa ali, saído dessa cena pra se tornar um dos skatistas mais reconhecidos do mundo, e voltando sempre que a agenda permite. Outros menos expressivos, mas não menos importantes. A molecada que pega o ônibus, o trem, o metrô, e chegam no centro com $\mathrm{R} \$ 0,50$. Pra sorte deles, talvez só lá seja possível comer alguma coisa com $\mathrm{R}$ \$ 0,50. Mas é o sonho que se realiza, de escorregar nas bordas do Vale, conhecer os ângulos da pirâmide da Sé, os caminhos sinuosos da Praça Roosevelt, o solo quase liso do Pátio do Colégio, onde São Paulo nasceu, ou outros picos mais obscuros. Ser do centro é um título, quase um diploma. Quem é, orgulha-se de ser. E é justo que assim seja (Disponível em: http://cemporcentoskate.uol.com.br/blogLer.php?categoria=9. Acesso em 20 de janeiro de 2011).

Ao longo de quase dois anos de trabalho de campo fui inúmeras vezes ao centro de São Paulo. A partir da maioria destas idas ocorreram certas regularidades. Muitos fatos foram observados, entretanto, para este capítulo foi necessário sintetizar alguns dos acontecimentos mais importantes que permitiram evidenciar as práticas e os discursos skatistas sobre o universo da modalidade street skate, como se verá a seguir.

\subsection{2 - "Rolê" no Vale do Anhangabaú}

Março de 2010. Aceito o convite de Rodrigo "Bocão”, para acompanhá-lo em suas constantes idas ao "Vale". Uma das motivações quanto a isso foi a possibilidade de retomar muitos contatos feitos inicialmente no Circuito Sampa Skate. Vários skatistas

\footnotetext{
${ }^{232}$ Rodrigo Teixeira é um famoso streeteiro brasileiro. Atualmente mora nos EUA, onde se destaca como skatista profissional.
} 
que freqüentaram esse evento disseram-me andar de skate com certa regularidade no Centro, como é o caso dos juízes e skatistas profissionais Sandro Sobral e Tiago Garcia, e também, de outros, como André Manto, Everton Canuto, Anderson "Finger", Alexandre "Nicolau", Vinicius dos Santos, etc.

Em uma segunda-feira, à tarde, encontro "Bocão" em seu serviço. Ele trabalha como estoquista, na editora responsável pela Revista Tribo Skate. Morador do bairro de Pirituba, dirige-se todos os dias úteis para Perdizes, Zona Oeste da cidade, onde se localiza a editora. Após às 15 horas, "Bocão" sai do trabalho com o skate em mãos e vai para outros lugares, à procura de picos para andar de skate. O "Vale" é o local mais freqüentado por ele. Bastante conhecido por outros freqüentadores, "Bocão" pode ser visto como um típico streeteiro paulistano.

Durante a espera por "Bocão", aproveito para pegar algumas revistas disponíveis no estoque. Em seguida, encontro Marcelo "Mug", que também trabalha no local. Ele então me relata sobre um churrasco feito por alguns skatistas de São Paulo na cidade de Guararema, em um banks público que lá se encontra. Em meio a uma reunião, regada a muita cerveja e pouca carne, os skatistas fizeram uma sessão de skate ao som improvisado de duas bandas de punk rock.

Minutos após, "Bocão" cumpre seu horário de trabalho. Após pegar o seu skate, fomos para a Estação Vila Madalena do metrô. De lá, o nosso destino seria a Estação São Bento, na região central. Durante o percurso, conversamos somente assuntos relacionados ao universo skatista: sobre os lançamentos em produtos, os campeonatos que se realizariam, as formas de se arrumar um patrocinador e sobre suas últimas sessões. Sem notar que o tempo passou, desembarcamos. Rapidamente descemos. Guiado por aquele que faz o mesmo trajeto quase todos os dias, fui ao encontro do tão falado Vale do Anhangabaú.

Já fora da estação do metrô, "Bocão" apontou para várias coisas, a fím de me apresentar um pouco mais daquele cenário: os grafites, os personagens, os equipamentos. Enfim, chegamos ao "Vale". O local, ao contrário do que eu imaginava, estava bastante cheio para uma segunda-feira. Por meio de um rápido olhar avistei pessoas em situação de rua, camelôs, homens de terno, policiais, estudantes e também, skatistas. Diante o ritmo frenético daqueles citadinos vistos no Centro, parecia haver tempo para o exercício de uma prática um tanto lúdica.

Enquanto caminhávamos, "Bocão" cumprimentava a todos os skatistas que passavam. Logo, atentei para esse importante código. Chegamos à borda infinita e ali 
ficamos ${ }^{233}$. Conseqüentemente, cumprimentei as pessoas que estavam sentadas, inclusive aquelas que não eram skatistas. Anderson "Finger" e Marcelo "Formiguinha" - esse último tido como o "Dono do Vale" - estavam lá. "Bocão" me disse que "Finger" estava machucado, mas, mesmo assim, não saía deste local. Ele andava por entre as pedras portuguesas, mandando manobras no chão ou tentando deslizar em algumas bordas. Não havia, por parte dele, nenhuma preocupação em acertar nada tecnicamente difícil. Por conta disso, entre uma manobra e outra, parava para conversar com os outros skatistas que estavam sentados.

Ao meu lado "Bocão" passava, mesmo que indiretamente, suas impressões sobre o "Vale". Pelo fato de ser local dali ${ }^{234}$, acostumou-se com todo o cenário e também com os diversos atores que ali circulam. Ele apontou o dedo para um homem, que estava sujo, andando sem direção e falando sozinho. "É apenas mais um louco", disse-me "Bocão", reiterando que essa pessoa sempre perambula pela região. Em seguida, ele apontou para outras, as quais identificou como sendo "mendigos" e "prostitutas" do Vale do Anhangabaú.

Neste contexto relacional, uma suposta distância simbólica e moral que separa skatistas e outros atores se constitui como situacional: no extenso banco de concreto, em frente às arquibancadas, estavam sentadas algumas garotas. Ao lado delas havia rapazes que trabalhavam na região e, também, um "mendigo". Observei que eles faziam o uso da maconha, compartilhada também por um skatista, que ora vinha até eles. Portanto, partindo desses fatos etnográficos, pode-se pensar o Vale do Anhangabaú como uma espécie de "esponja" da cidade - para utilizar uma expressão de Joseph $(2005,111)$-, ao levar em conta, de acordo com certas situações, as aproximações e os distanciamentos nos relacionamentos estabelecidos entre os citadinos em um mesmo espaço.

Após um tempo observando, percebi que os equipamentos do "Vale" podem ser divididos em quatro blocos, os quais contam com tipos de picos, como solo, gap, manuais e bordas. O solo é o chão de superfície lisa, que possibilita a realização de manobras; já os gaps são os espaços que os skatistas tentam pular, como as escadas e os canteiros; os manuais, por sua vez, são os degraus da arquibancada que permitem a

\footnotetext{
${ }^{233}$ Rodrigo "Bocão" referiu-se à borda infinita tendo em mente uma extensa borda de concreto que fica em frente às arquibancadas.

234 Ser local indica que o skatista possui um determinado espaço como referência para a prática. Por exemplo: Rodrigo "Bocão" é local do Vale do Anhangabaú. Logo, o espaço que ele mais freqüenta para praticar o street skate é esse que foi apontado. Contudo, é importante ressaltar que ser local de uma pista ou de um pico não quer dizer que o skatista deixe de freqüentar outros espaços para a prática.
} 
realização de manobras onde se equilibra somente com duas das quatro rodas do skate, sejam elas dianteiras ou traseiras; por fim, as bordas são as quinas das arquibancadas, que possibilitam o deslize com o skate. Para que isso seja feito, os skatistas usam a parafina (pedaços de vela), passada em toda a extensão da borda.

Observei alguns skatistas nos manuais, acompanhados de um videomaker, realizando algumas manobras. Eles pareciam ter vindo ao "Vale" juntos. Porém, essa forma de sociabilidade sofreu um novo arranjo a partir do momento em que os mesmos passaram a andar nas bordas e a dividir o mesmo espaço com outros. Com base nisso, é importante pontuar que, de acordo com o pico onde se está, novas relações são (re)estabelecidas, possibilitando o cruzamento e a ampliação das redes que se formam.

Sandro Sobral, Alexandre "Nicolau" e o fotógrafo Adriano chegaram ao local onde estávamos. Enquanto isso Marcelo "Formiguinha" machucou a canela com seu skate e resolveu ir embora. Do meu lado, sentou-se um homem, conhecido de alguns skatistas, apesar de não andar mais de skate. Ele me disse que está sempre pelo Centro, em busca de mercadorias para revender e entre uma tarefa e outra consegue tempo para vir ao "Vale" ver algumas sessões de skate e conversar com antigos amigos.

Alexandre "Nicolau" aproximou-se para me contar alguns recentes fatos ocorridos em sua vida. Naquele momento ele estava desempregado. Com o tempo livre, dedicavase integralmente ao skate. O seu grande objetivo é conseguir alguns patrocinadores para, quem sabe, se profissionalizar. Porém ele considera-se velho, com seus 30 anos, para atingir tal feito. "Nicolau" relatou-me que está sempre fazendo "correrias" para se manter como skatista ${ }^{235}$. Em função disso, ele tenta contatar fotógrafos e videomakers. A sua idéia, após a captação dessas imagens, é produzir um material promocional que será enviado para representantes de marcas de produtos para skate. Além disso, "Nicolau" produziu um portfólio, para ser entregue junto das imagens ${ }^{236}$. Com isso ele pretende mostrar, além de seu nível técnico, que sabe "conversar" e lidar com eventuais patrocinadores. Apesar de todo esse esforço, segundo seu relato, a situação está difícil,

\footnotetext{
235 "Correria" possui vários significados e é um termo bastante recorrente (embora não exclusivamente) nas conversas com os skatistas. Nesse contexto, fazer "correria" pode ser visto como a realização de várias atividades a fim de conquistar benefícios que tragam resultados práticos. O skatista Jorge Costa define, de acordo com sua perspectiva, o que entende do termo: “"correria' pode ser: você pode estar filmando sua parte de vídeo; você pode estar fazendo fotos para uma revista ou você pode estar tentando se agilizar de alguma forma, tentando arrumar patrocínios, vender materiais de skate ou tentando juntar grana para viajar. Tudo isso é usado como uma 'correria'. É se manter em cima do skate" (Entrevista em 19 de março de 2010). Para uma discussão a respeito da trajetória de certos skatistas a partir da realização de "correrias", vide Bastos (2006; 2009).

${ }^{236}$ Vide Anexo C.
} 
pois o mercado está cada vez menos interessado em patrocinar ou ao menos apoiar os praticantes. "Nicolau" também não pretende se focar tanto mais em campeonatos. Nos últimos anos, ele conseguiu boas colocações no Circuito Sampa Skate, o que já prova sua capacidade em competições. Ainda que ande em pistas, ele se considera um típico streeteiro. Morador da Zona Leste, "Nicolau" vem ao "Vale" quase todos os dias. Mesmo assim, não deixa de visitar o banks da Plasma, pista de skate situada no Shopping Aricanduva, próximo de sua residência.

Perto das bordas, uma garota andava de skate sozinha. Após um tempo, ela nos cumprimentou. Ao conversar com "Bocão" e com os outros presentes, a skatista relatou alguns preconceitos sofridos por ser uma "mulher que anda de skate". Certa vez, alguns homens que não eram skatistas disseram a ela o quão estranho é uma garota tentar andar de skate. Em contrapartida, a garota disse ter apresentado uma série de argumentos que comprovam que a prática do skate entre as mulheres está cada vez mais em ascensão ${ }^{237}$.

Já no fim da tarde, Sandro Sobral sugeriu que fossemos para o Rei do Mate, lanchonete situada próxima à Galeria do Rock. Todos concordaram. No caminho ainda encontrei Jorge Costa, andando em algumas bordas. Após uma breve caminhada, chegamos ao nosso destino. O Rei do Mate é onde muitos skatistas se encontram após as sessões de skate no "Vale". Os próprios funcionários da lanchonete são bastante íntimos e conhecem os freqüentadores pelo nome. Enquanto degustam seus lanches, estabelece-se uma intensa conversa entre os presentes. Alguns, inclusive, comentam as sessões que fizeram ou combinam novas que poderão ser feitas.

Após o lanche, Rodrigo "Bocão" me convidou para ir ao escritório da Future Skateboards, marca de produtos para skate comandada pelos skatistas Fábio Brandão e Tiago Garcia. O local fica no alto de um prédio, situado na Avenida Ipiranga. Além dos responsáveis pela marca, estava presente o skatista e rapper Kamau. O expediente de trabalho já havia acabado e, com isso, eles aproveitaram para ver vídeos de skate na Internet.

Saímos à noite do escritório. Voltamos para o Rei do Mate. Lá encontramos mais skatistas, com os quais ficamos conversando. Um tema recorrente foi a preferência musical de cada um. Ficou claro que, pelo menos entre eles, é o rap. Percebi ainda a influência desse estilo musical: além de trocarem informações sobre LP's, CD's e

237 Para mais informações sobre a prática do skate entre as mulheres, vide Anexo B. 
shows, eles se vestiam com roupas largas, configurando o estilo que os próprios chamam de gangueiro ${ }^{238}$, ou seja, aquele skatista que anda "no estilo do rap".

Em um outro momento, retornei ao Vale do Anhangabaú. Inicialmente, fui com Rodrigo "Bocão". Porém, dentro do metrô, ele me informou que não poderia ir ao Centro naquele instante, pois devia ir ao bairro da Lapa resolver algumas pendências. Diante da sua ausência, resolvi prosseguir o resto do trajeto sozinho. Fiquei um pouco receoso quanto à minha chegada ao "Vale", visto que "Bocão" era, naquele momento, o principal interlocutor. Quando cheguei ao local, percebi que não conhecia ninguém, salvo alguns de vista. Destarte, caminhei por entre os picos, somente observando o que acontecia. De longe avistei Sandro Sobral. Como já o conhecia, fui ao seu encontro. Porém, ele não me viu e caminhou rapidamente para o sentido contrário, indo embora do local.

Resolvi ir à Galeria do Rock, local famoso por suas inúmeras lojas, as quais são bastante freqüentadas pelos skatistas. Após chegar lá notei que muitos deles, inclusive alguns que andam no "Vale", trabalham em lojas especializadas em produtos para skate, as chamadas skateshops. Em suas vitrines é notável o foco atribuído às vendas de peças para a modalidade street skate.

Volto ao "Vale". Anderson "Finger" e Alexandre "Zikkzira" andavam em uma borda reta, tentando realizar uma única manobra. Concomitante, alguns policiais e guardas municipais circulavam pelo local. Pelo menos ali, eles não faziam nenhum tipo de restrição à prática do skate nos equipamentos públicos, visto que estavam preocupados com a presença das pessoas que dormiam pelas escadas da arquibancada ou pelas áreas gramadas do Vale do Anhangabaú.

Passado um tempo, Adriano, fotógrafo que trabalhou em algumas etapas do Circuito Sampa Skate, chegou aos picos. Ele marcou um encontro com amigos. Como não os havia encontrado, resolveu visitar algumas lojas de equipamentos fotográficos, que não ficavam tão longe dali. No final da tarde, Sandro Sobral retornou para andar de skate. Após me cumprimentar, fez uma série de desabafos em relação ao mercado especializado que, segundo ele, está cada vez mais amador e sucateado. Sobral acredita que isto se dá em virtude da atuação de empresários que não entendem nada de skate e que querem somente lucrar com os skatistas, sem dar-lhes nenhum tipo de retorno.

238 Gangueiro, enquanto categoria de distinção entre os próprios streeteiros, pode ser entendido como um estilo que se dá a partir de trocas simbólicas entre o universo do skate e o universo do hip hop. Contudo, vale a pena ressaltar que nem todos aqueles que compartilham dessas distintas experiências e códigos destes universos se vêem como tal. 
Não demorou muito para que outros skatistas chegassem para fazer suas sessões. No "Vale", praticantes de distintas categorias andam juntos no mesmo espaço. Sabendo disso, não estranhei quando vi skatistas da categoria amadora andando ao lado de profissionais, o que propicia o aprendizado mútuo da técnica para aqueles que praticam. O fotógrafo Fellipe Francisco, ao lado da namorada Eliana Sosco e da amiga Euli Vieira, também se aproveitava de alguns picos, assim como os profissionais Vitor Sagaz e Alexandre Tizil, além do skatista finlandês Jani Latiaia. Em meio a isso, Alexandre "Zikkzira" parou de andar. Em seguida, o skatista amador Léo Fernandes aproximou-se dele, para propor uma troca de jogos de rodas, situação que gerou uma negociação entre os envolvidos.

Após freqüentar várias vezes o "Vale", percebi algumas alterações na dinâmica das sessões realizadas, de acordo com o período em que são praticadas. Na parte da tarde, os skatistas encontram-se espalhados pelos diversos blocos - conseqüentemente, pelos diversos picos que os compõem - formando pequenas aglomerações. Já na parte da noite, devido a uma melhor iluminação do local, os skatistas se concentram no primeiro bloco, onde formam um aglomerado maior e mais denso. Nesse período, com a pouca circulação de pedestres pela área, é possível andar de skate com mais tranqüilidade.

André Manto, outro participante do Circuito Sampa Skate, também freqüenta o "Vale" quase todos os dias. Somente nos finais de semana é que ele anda em outros picos da cidade. No momento de nosso encontro, ele trabalhava no Centro, no escritório da Brasil Skate Camp ${ }^{239}$. Ao lado de Renan Hassan, André me chamou para ir ao Rei do Mate. Aceitei o convite. Em nosso curto trajeto, me contou sobre uma sessão que havia feito em companhia de um fotógrafo, em um bairro próximo à sua residência, na Zona Leste. Nessa sessão ele tentou mandar uma manobra em um caixote anexo a uma escadaria, que se localiza na porta de um bar, cujo dono foi cordial e permitiu a eles realizarem tal ato.

Fábio Brandão, Tiago Garcia e Rodrigo "Bocão" já estavam no Rei do Mate. Como Renan Hassan estava sem dinheiro naquele momento, André Manto se ofereceu para pagar seu lanche. Não ficamos muito tempo na lanchonete, pois os presentes queriam andar de skate. Para ir ao "Vale", cortamos caminho por um espaço feito de pedras portuguesas. Em meio a isso, paramos em frente a uma loja de sapatos, onde há

239 Brasil Skate Camp é um acampamento para crianças e adolescentes, cuja temática é o skate. 
um círculo de superfície lisa no chão. Tiago Garcia exclamou: "sinta o cheiro da rua!", enaltecendo a importância das ruas para o street skate. Os skatistas começaram a realizar uma espécie de brincadeira. Perguntei a eles do que se tratava e me disseram que no "redondo", forma como este espaço é chamado, é feito um jogo que pode envolver vários skatistas. O objetivo é cada um acertar a manobra ou a sequiência de manobras ditada pelo escolhido. "Bocão" foi o escolhido para mandar a primeira manobra e optou por um backside flip. Todos tentaram repeti-la, mas ninguém conseguiu. Em seguida, outro skatista foi escolhido. Ele então mandou uma manobra diferente. A brincadeira prossegue até que todos consigam acertar aquilo que fora proposto. Enquanto isso não acontece, eles não seguem a caminhada até o "Vale". Esta é uma das formas de aprendizado de manobras por parte destes streeteiros. Por meio de simples brincadeiras, eles são levados a incorporar e desenvolver certas técnicas, compartilhadas por meio de suas experiências vivenciadas.

Acompanhado por "Bocão", retorno ao "Vale" no dia seguinte. Era uma quartafeira e havia mais skatistas que nos dias anteriores. No primeiro bloco das arquibancadas, estavam alguns praticantes os quais nem "Bocão" conhecia. Segundo ele, é a "molecada mais nova". Por serem novatos ali, inicialmente não se enturmam com os outros. Já nas arquibancadas do segundo bloco, havia dois skatistas: "Gui" Martins e João Brinhosa, o último de Florianópolis - SC. João nos contou aquilo que acabara de acontecer com ele. O retorno para sua cidade estava marcado para a manhã daquele dia. Após sua chegada ao aeroporto de Guarulhos, fez o check in e em seguida foi lanchar. Ao voltar para o embarque, percebeu que havia perdido o vôo. João estava em uma situação um pouco complicada, visto que trabalharia no próximo dia. Resolveu, então, voltar à sua cidade de ônibus, embora isso só fosse possível à noite. Como a espera demoraria horas e ele não conhecia muito bem a cidade de São Paulo, decidiu ir ao "Vale", encontrar outros skatistas, e esperar o tempo passar.

Naquele momento, não era somente João Brinhosa que fazia do "Vale" um ponto de encontro. Também chegaram dois gaúchos ao local: os profissionais Daniel "Crazy" e "Gui" da Luz, acompanhados pelo paulistano Bruno Agüero. Vale ressaltar ainda a presença de dois turistas argentinos, que foram até alguns skatistas perguntar se eles conhecem Esteban Florio, profissional da Argentina que reside em nosso país, fato que comprova, mais uma vez, a importância do Vale do Anhangabaú como referência para a modalidade street skate no Brasil. 
Durante um curto tempo, a pedido dos próprios skatistas, fiquei sentado nas arquibancadas olhando algumas mochilas ${ }^{240}$. Enquanto isso Anderson "Finger" tentava mandar uma manobra nas bordas, sendo essa fotografada por outra pessoa. Em meio à sessão de fotos, passou um "morador de rua", o "louco" a que "Bocão" se referira no começo do tópico. Após algumas conversas, os skatistas convenceram-no a posar para uma foto junto deles, segurando o skate e fazendo gestos com os dedos das mãos.

Fim de tarde. Hora de ir para o Rei do Mate. Mas antes, o skatista Samuel "Salva" pediu-me para deixar seu skate na Sigilo Skateshop, localizada na Galeria do Rock. Feito isso, em companhia de "Bocão", fui para a lanchonete. Após o lanche, resolvemos ir ao escritório da Future Skateboards. Outro skatista amigo de "Bocão" nos acompanhou. Ao passarmos pela Avenida Ipiranga, já em frente ao prédio onde se encontra o escritório, observamos várias viaturas estacionadas na calçada com as sirenes ligadas. Ao lado delas estavam policiais fortemente armados, com metralhadoras e escudos. Ficamos receosos quanto aos acontecimentos, pois os amigos dos skatistas estavam no interior do prédio. "Bocão" tentou perguntar a um dos policiais sobre o que acontecia, mas não obteve qualquer tipo de resposta. Diante do clima de tensão, imaginei que os skatistas com os quais eu estava, iriam embora. Mas não foi o que aconteceu. Eles apenas atravessaram para o outro lado da avenida e, em seguida, colocaram seus respectivos skates no chão. Em meio a uma multidão de pessoas e carros circulando para todos os lados, lá estávamos nós, atentos aos acontecimentos. Para aumentar a preocupação, aqueles que estavam no escritório não atendiam aos telefonemas.

Diante das indecisões que se configuraram, os skatistas resolveram voltar para o Rei do Mate. Porém, não ficaram dentro do estabelecimento, pois preferiram se sentar no centro da calçada, em cima de seus skates. Para alívio de todos, aqueles que estavam no edifício apareceram onde estávamos, embora não tenhamos sabido ao certo o que de fato acontecera.

Com base no que foi apresentado, percebe-se como os skatistas possuem formas particulares de interação com os equipamentos e com as situações vivenciadas no centro de São Paulo. Enquanto esse espaço para muitas pessoas configura-se como um local de serviço, trabalho e circulação, para os skatistas, ao contrário, a região central é onde se 240 Apesar dos skatistas considerarem o "Vale" seguro, eles não deixam de ficar atentos aos seus
respectivos pertences, que são deixados em cima das arquibancadas. 
estabelecem formas de sociabilidade marcadas, a princípio, pelo exercício de uma prática esportiva.

Passado o susto, fomos para o metrô. Devido ao cansaço, alguns presentes estavam com sede, entretanto, não havia como tomar água. Um skatista, já no interior de Estação São Bento, resolveu essa situação, localizando, atrás de uma placa, uma torneira escondida. "Depois da sessão, qualquer torneira!", disse-me um deles. A partir daí, alguns outros skatistas que se encontraram no "Vale" resolveram ir para a Zona Sul da cidade, na festa de aniversário de André "Hiena".

Outra incursão a campo importante para a compreensão da prática do street skate no Centro se deu na mesma semana dos últimos relatos apresentados. No período da tarde de uma sexta-feira, após um dia de fortes chuvas, havia a incerteza quanto às sessões de skate no "Vale", pois o local provavelmente estaria molhado. Novamente fui sozinho, pois "Bocão" resolveu, de última hora, ir andar de skate no Parque do Ibirapuera, outro local bastante freqüentado pelos streeteiros.

Após chegar ao "Vale", encontrei André "Hiena", Sandro Sobral, Alexandre "Nicolau", Renan Hassan, dentre outros. Com intuito de observar as sessões, sentei-me na borda infinita, em frente às arquibancadas, onde alguns streeteiros mandavam manobras, a fim de "manter o skate no pé" ${ }^{241}$. De repente, começou uma forte chuva. Como o "Vale" evidentemente não é coberto, muitos foram para o Rei do Mate. Lá encontramos mais skatistas, entre eles, o videomaker Victor Ferrari. Ele me contou da produção de seu vídeo, chamado Seleção Natural, que antes mesmo do lançamento já era considerado uma das principais novidades do ano 2010. Victor disse que estava somente de passagem pelo Centro. O local onde mais anda de skate é o Parque do Ibirapuera, situado muito próximo à sua residência. Em seguida, convidou-me para encontrá-lo nesse pico, convite aceito dias após.

Ainda no Rei do Mate, André Manto insistiu para que fôssemos à Praça Roosevelt. Todos concordaram. Há, nesse espaço, locais cobertos que permitem a prática do skate. Mesmo chovendo, fomos a pé. Para nossa surpresa, outros skatistas tiveram a mesma idéia: com sua equipe de skatistas, a marca nordestina Myllys estava por lá, aproveitando os principais picos da cidade.

A Praça Roosevelt é um desses locais, desde a década de 1980. No ano de 2010, os próprios skatistas fizeram melhorias nesse espaço, tornando-o ainda mais skatável.

241 "Manter o skate no pé" é uma expressão utilizada pelos streeteiros, para se referirem ao aperfeiçoamento da técnica de certas manobras. 
Para o evento chamado "DC King of São Paulo", promovido pela marca de tênis DC Shoes, foi construída uma hubba, isto é, uma borda de mármore inclinada, colocada em uma espécie de palanque da praça. Após a construção desse e outros obstáculos, a praça passou a novamente receber praticantes do street skate.

Ainda estava chovendo. A sessão de skate não renderia muito. Como era sextafeira, alguns skatistas aproveitaram para ir embora, pois sairiam novamente mais tarde, dessa vez, não para andar de skate. O objetivo era ir a uma "balada" de rap, chamada Mary Pop, localizada no próprio Centro. Antes disso, alguns deles combinaram de andar de skate durante o final de semana, na Avenida Paulista, local que conta com inúmeros picos.

Essas foram algumas das experiências vividas ao lado de skatistas provenientes das mais diferentes regiões, que têm como ponto de referência o Vale do Anhangabaú. Enquanto alguns espaços possuem o foco voltado, sobretudo, para o exercício de uma prática esportiva - como em muitas pistas -, o que se nota na região central da cidade são, além disso, formas de sociabilidade estabelecidas entre os skatistas a partir de situações e apropriações de espaços urbanos ${ }^{242}$, os quais, a principio, não foram construídos tendo em vista a prática do skate.

\section{5 - Skate (não) é crime}

Assim como o Vale do Anhangabaú, o Parque do Ibirapuera é um dos locais mais importantes para a prática do street skate na cidade de São Paulo ${ }^{243}$. Uma simples volta pelas imediações de sua marquise comprova este fato ${ }^{244}$ : em quase todos os dias da

\footnotetext{
${ }^{242}$ Frúgoli Jr. (1995, 67), em sua pesquisa, realizada na década de 1990, sobre os espaços públicos e interação social na cidade de São Paulo, já chamava a atenção para algumas situações que se aproximam daquelas encontradas no atual contexto do street skate praticado no Centro: "os grupos de jovens freqüentados desses espaços do centro tradicional apresentam algumas características comuns: são provenientes das camadas populares, com grupos muitas vezes formados na periferia, que se dirigem ao Centro, ou que estabelecem redes de relações nos espaços centrais da cidade; são predominantemente masculinos, com escassa participação de mulheres, ao menos quanto à sociabilidade realizada nos locais citados, o que provavelmente se transforma quando da realização de bailes ou festas; (...); delimitam determinados territórios, muitas vezes ligados a algum equipamento específico - galeria, barbeiro, loja de disco, espaço para dança, etc. - no qual estabelecem relações, combinando com trajetos grupais pela cidade (ainda que alguns grupos não contem com algum ponto em particular nessa região); a música constitui um importante universo de referência, seja como pano de fundo para sociabilidade ou dança, ou como articuladora de valores simbólicos dentro do campo da indústria cultural (...)".

${ }^{243}$ O Parque do Ibirapuera está localizado em torno da Avenida Pedro Álvares Cabral, na cidade de São Paulo.

${ }^{244}$ Em uma matéria chamada "Chão Sagrado", a Revista CemporcentoSkate (edição 138, 2009, 58) ressalta a importância deste local para a prática do skate: "tombada pelo patrimônio histórico, a Marquise do Parque do Ibirapuera (com 650m de extensão, distribuídos em uma área total de $27 \mathrm{mil} \mathrm{m}^{2}$ ) é
} 
semana também é possível encontrar dezenas de skatistas, que circulam pelo chão de superfície lisa do referido espaço.

E não é de hoje que o local é freqüentado pelos streeteiros. Em meados da década de 1980, momento em que o street skate se consolidava no universo do skate, o Parque do Ibirapuera já se constituía enquanto um espaço de sociabilidade para praticantes provenientes de diversas regiões da cidade. Ao mesmo tempo, nessa época, a prática do skate carregava fortemente consigo o rótulo de "marginal" e "transgressora" ${ }^{245}$. E foi em virtude disso que alguns skatistas tiveram que manifestar e se posicionar politicamente para conquistar o direito de praticar num parque público.

Em 1988, o então prefeito Jânio Quadros decidiu proibir a prática do skate durante os finais de semana e feriados nas dependências do Parque do Ibirapuera. Esse fato revoltou vários skatistas freqüentadores do local, que decidiram protestar diante de tal atitude. Um dos organizadores do protesto fora Márcio Tanabe, interlocutor entrevistado no capítulo anterior. De acordo com o mesmo, com várias faixas e muito barulho, os skatistas foram da Estação Paraíso do metrô até a porta do parque, que estava fechada e com a seguinte placa: "Proibido acesso de bicicletas e skates aos sábados, domingos e feriados". Embora com a indignação de crianças, jovens e adultos presentes, o protesto realizou-se pacificamente. Ao saber desse acontecimento, Jânio Quadros adotou uma postura ainda mais inesperada: ao invés de permitir o skate no parque, o proibiu em todas as ruas da cidade de São Paulo. Ele alegava a periculosidade da prática, a qual poderia trazer riscos não só para os praticantes, como também para outros usuários das ruas.

Aquilo que antes estava restrito a um único espaço tomou grandes proporções. Concomitantemente, esta proibição do skate obteve visibilidade em vários jornais e

testemunha de boa parte da história do skate de São Paulo, e porque não afirmar, do país. Projetada pelo mestre da arquitetura Oscar Niemeyer, que involuntariamente contribuiu para o skate com inúmeras obras, o local é mesmo um patrimônio da cidade e dos skatistas paulistanos. Construída em 1954, a Marquise foi elaborada para celebrar o IV Centenário da fundação da cidade de São Paulo. O espaço serve como conexão entre os cinco principais edifícios presentes no parque, o Auditório Ibirapuera, construído recentemente para completar o projeto original de Niemeyer, e outros quatro pavilhões que hoje abrigam alguns dos mais importantes museus da metrópole, como o MAM (Museu de Arte Moderna), o Afro-Brasileiro e a Bienal de São Paulo".

${ }_{245}$ Para uma análise mais aprofundada, vide Brandão (2008). Ao analisar a prática do street skate em idos da década de 1980, esse referido autor salienta: "se de um lado é possível enxergar práticas de apropriação dos espaços urbanos pelas manobras do skate (...), de outro lado existe a cidade enquanto um organismo funcional, que detecta, seleciona e analisa seus componentes urbanos. Os skatistas, sujeitos indesejáveis quando o assunto é manter a ordem e a disciplina, foram muitas vezes classificados como arruaceiros, agitadores ou baderneiros" $(2008,21)$. 
revistas ${ }^{246}$. Muitos questionavam: “skate é crime?”. A Yeah! foi a revista que deu mais espaço àquilo que ocorrera. Na capa de uma edição, lançada no ano de 1988, trouxe em letras garrafais a seguinte frase: "Andar de skate não é crime”. Ainda na mesma edição foi publicado um texto que tratava ironicamente os fatos acontecidos:

Cuidado! Você é um skatista. E está sendo observado. Coloque o seu skate no chão. E prepare-se para a guerra. Você não pode mais se divertir. Você não pode mais praticar um esporte. Porque agora você é um criminoso! E ao lado de milhares de outros criminosos você terá que resistir. Você será recrutado. E lutará na legião dos perseguidos. Você irá pras ruas. Armado com seu skate (“Andar de skate não é crime”. Yeah!, número 10, 1988, 44, grifos meus).

Apesar da proibição do skate na cidade de São Paulo, os skatistas não deixaram de ir para as ruas nem para o Parque do Ibirapuera, mesmo sob o risco de algumas punições, como a apreensão de skates por parte de policiais e guardas municipais. Esta ação somente foi revogada na gestão da prefeita Luiza Erundina (PT, 1989-1992). Com base nesse desfecho, pode-se dizer que na "guerra" pelos usos dos espaços públicos ${ }^{247}$, os skatistas ganharam mais uma batalha ${ }^{248}$.

Estes fatos apresentados foram constantemente acionados por muitos streeteiros interlocutores desta pesquisa, mesmo aqueles que não andavam de skate ou que não eram nascidos na época do ocorrido. Atualmente a situação é diferente, visto que os

\footnotetext{
${ }^{246}$ O jornal Folha de São Paulo, em matéria intitulada "Jânio proíbe uso de skate em S. Paulo", publicou: "o prefeito de São Paulo, Jânio Quadros, 71, irritado com a passeata promovida anteontem por praticantes de skate contra a proibição de seu uso nos fins-de-semana no Parque do Ibirapuera (na zona sul), decidiu proibir que os skatistas circulem por todas as ruas da cidade. Em memorando ao secretário municipal dos transportes, coronel reformado da PM Geraldo Penteado, Jânio solicita 'deter e levar ao Juizado de Menores todos aqueles que praticarem esse 'esporte', no leito das ruas e nos logradouros públicos'" (Folha de São Paulo, 25 de junho de 1988).

247 Neste contexto, a utilização do termo "guerra" toma como base a matéria anteriormente citada, elaborada pela Revista Yeah!.

${ }^{248}$ No ano 2003, de acordo com matéria da Folha de São Paulo, novamente tentou-se barrar a prática do skate na Marquise do Parque do Ibirapuera. Porém, a tentativa, devido a algumas especificidades, não deu certo: "um decreto da Prefeitura de São Paulo, publicado no último dia 17, restringe a prática de atividades esportivas sob a marquise do parque Ibirapuera (zona sul). O objetivo, de acordo com a Secretaria Municipal do Verde e do Meio Ambiente, é evitar acidentes no local. Desde o último sábado, dois cartazes avisam os usuários do parque da nova regra. As crianças e adolescentes que costumam se reunir na marquise para andar de skate, patins e bicicleta poderão continuar com a prática, considerada uma atividade recreativa pela secretaria. A proibição, de acordo com a assessoria de imprensa da secretaria, vale para skatistas e patinadores considerados profissionais. A justificativa, ainda de acordo com a assessoria, é que os profissionais desses esportes costumam fazer manobras mais arriscadas, causando acidentes - principalmente envolvendo crianças" (Ibirapuera veta esporte radical em marquise. Disponível em: http://www1.folha.uol.com.br/folha/cotidiano/ult95u84672.shtml. Acesso em 21 de janeiro de 2011).
} 
skatistas não encontram tantas restrições quanto à prática no Parque do Ibirapuera ${ }^{249}$, que se constitui como mais um ponto de encontro para os praticantes.

\subsection{1 - Skate embaixo da marquise}

Em meio a uma extensa área verde encontra-se um amplo espaço coberto e com a superfície completamente lisa. Essa é a marquise do Parque do Ibirapuera. Diante uma multidão de pessoas que por lá circulam, é praticamente impossível deixar de notar a presença de inúmeras "rodinhas" em movimentos constantes. Patins, patinetes, bicicletas e, é claro, skates, de todos os tamanhos: desde aqueles maiores, os chamados longboards, até os menores, para prática do freestyle. Dentre eles, os mais utilizados são os skates da modalidade street skate, com seus shapes finos e côncavos, com seus eixos curtos e baixos e com rodas de até 55 milímetros.

Mas o que há de tão especial no Parque do Ibirapuera que mantém viva a prática do street skate ao longo de vários anos? Ao contrário do Vale do Anhangabaú, que oferece uma variedade de picos, a única coisa que se pode encontrar embaixo desta marquise, a princípio, é o seu amplo chão liso. E é nele onde se pode fazer um solo, isto é, realizar algumas manobras no referido espaço:

Lá não tem muito obstáculo, mas pelo menos o chão é liso, e você pode andar a qualquer hora do dia, da noite, fazendo solo. Lá é um pico válvula de escape. Não tem para onde ir, encontra a galera (Raphael "Pezão", entrevista em 29 de março de 2010).

Através do exercício de manobras no solo, os skatistas aperfeiçoam o equilíbrio, controlando e coordenando seus corpos, tendo em vista a eficácia técnica. A partir do momento em que se tenta uma manobra e há mais acertos do que erros, pode-se dizer que o praticante está pegando a base. Quanto mais base de uma manobra ele tiver, mais facilidade terá com a prática do skate nos mais diferentes picos:

Se você vier aqui todo dia, andar todo dia, você vai pegar a base de umas manobras de solo. Só que é assim: se você não tiver coragem, não tiver vontade [você não pega]. Assim, se você sabe dar manobras no chão

\footnotetext{
249 Para mais informações sobre outras práticas esportivas nos equipamentos do Parque do Ibirapuera ver o artigo: “O que é que o Ibirapuera tem? Le Parkour e 'esportes radicais' no parque" (Marques, 2008).
} 
perfeito, e não quer tacar num gap, então não adianta muito. Tem cara que nem faz muito solo e vai andar em gap e dá várias manobras. É porque acostuma a andar em gap. Se o cara que faz solo começar a jogar as manobras no gap, ele vai acertar e com certeza vai ser mais bonito ou mais fácil do que um cara que só anda em gap. Eu penso assim. Desenvolve a base da manobra, a forma que você gira, a forma que você chuta, dá para treinar muito estas coisas (Caio Youssef, entrevista em 15 de abril de 2010).

Desse modo, de acordo com a perspectiva de alguns interlocutores, o "Ibira" forma que o Parque do Ibirapuera é chamado pelos skatistas - é um bom local para pegar a base de certas manobras. No entanto, não basta ter somente essa base no solo: é preciso desenvolvê-la em picos que contam com maior grau de dificuldade e que ofereçam maiores riscos. Estes fatores valorizam a manobra realizada.

Enquanto no Vale do Anhangabaú é mais aceitável a constante presença de streeteiros, no "Ibira", ao contrário, a permanência somente a este local precisa ser ponderada, tal como nas pistas. Não importa se o skatista desloca-se até este espaço todos os dias. Entretanto, ele não deve se prender somente ao mesmo, tendo em vista as poucas opções de picos oferecidas:

Skatista que é skatista anda em qualquer lugar, já começa por aí. Então eu faço um solo aqui, mas sempre tento colar em outros picos. Tento andar em borda, tento colar no "Vale", tento colar na Sé, na Roosevelt, tento colar nas pistas, tento filmar nas ruas. É diferente. Até porque você ficar muito tempo no mesmo pico, você cansa (Caio Youssef, entrevista em 15 de abril de 2010, grifos meus).

O Ibirapuera é muito legal, mano! O que acontece lá é que a preguiça do ser humano, se você deixar, ela toma conta. E o Ibirapuera ele é grande, o chão é liso, você pode ficar passeando e tudo mais. Só que daí você cai no comodismo. Se você ficar andando sempre lá, você pára de evoluir. Você fica só andando em solo. Quem começou a andar de skate lá dos meus amigos, eu tive que começar a parar de colar sempre, porque eu estava me atrasando. Eu só ficava no solo, nas mesmas. Os caras querem sempre acertar do que errar. Pô, se você ficar só dando as que você acerta, você não vai para frente (Raphael "Pezão", entrevista em 29 de março de 2010, grifos meus). 
A partir do momento em que uma pessoa resolve se tornar praticante do skate, as suas habilidades no solo são desenvolvidas primeiramente. E por contar com demasiado espaço desse tipo, o "Ibira" é um local que atrai muitos principiantes, os quais estão começando a dar seus primeiros passos, ou melhor, impulsos, em cima do "carrinho". Por isso é notável nas visitas ao parque, a presença de muitas crianças com seus skates:

Os pais que andaram de skate nos anos 80, estão ligados que lá é um pico famoso para andar de skate. É seguro, é dentro do parque. É uma galera que tem grana, leva o filho lá, e deixa ele sair "remando". Não tem perigo nenhum. Quanto mais você vê gente andando de skate, mais gente vai andar. E tem o lance de dificuldade. O "Vale" é difícil de andar. Quem não sabe andar de skate, vai ralar. Lá vai desistir. No Ibirapuera você começa a aprender rápido, tem um monte de gente de andando, vai te ensinar. Você começa do zero, devargazinho. Então lá tem muita gente aprendendo a andar (Raphael "Pezão", entrevista em 29 de março de 2010).

$\mathrm{Na}$ real, dia de semana o que mais cola é isso. Molequinho tentando aprender. Mãe que trás o filho em um dia mais calmo. Mãe senta na pilastra, fica lendo e o filho andando aqui na frente, tentando aprender as coisas (Caio Youssef, entrevista em 15 de abril de 2010).

Por conviverem com praticantes de todos os níveis técnicos, os skatistas que freqüentam o "Ibira" há mais tempo ainda julgam - com base na técnica e no domínio de certos códigos - aqueles que andam de skate apenas por "moda" e aqueles que andam de "verdade". Os que andam por "moda" são os que raramente praticam o skate e que se aproveitam dele apenas como um tipo de passatempo em suas visitas ao parque. Já os skatistas de "verdade" são aqueles comprometidos com a prática, que regularmente freqüentam o parque ou outros espaços, e que vivenciam as experiências do universo do skate. Portanto, a prática do skate pode ser feita por qualquer um, embora nem todos que as faça se assumam enquanto "skatistas".

Embora o solo seja preponderante na Marquise do Parque do Ibirapuera, alguns skatistas utilizam criativamente outros espaços, como algumas paredes (wallrides) e quinas de pilastras (bordas). Esses exemplos, no entanto, são mais raros, visto que a utilização dos equipamentos citados requer um considerável nível técnico do praticante. Aproveitando-se do solo, certos streeteiros também levam obstáculos fabricados por eles ao parque, como pequenos corrimãos (trilhos) e caixotes de madeira com quinas de 
cantoneiras (palquinhos). Os simples obstáculos utilizados de forma improvisada tornam-se, em muitas sessões, o foco da prática no "Ibira", atraindo diversos skatistas:

Quando vem algum local, coloca um palco aqui e começa a colar direto com este palco, vem cara até da Zona Leste. Vem, faz uma sessão, troca uma idéia, descobre que o cara vem direto, e conta para um camarada, que conta para outro camarada. Daí, você vai ver, tem 30 malucos andando num palquinho. Que nem na sexta-feira você viu. Tinha um palquinho para 30 caras. Teve uma época que tinha um cara de São Caetano, que era o "Nit", que vinha com dois palcos animais e deixava aqui à noite e ficava todo mundo andando. Chegou uma época que tinha quarta, quinta e sexta, vinha pelo menos uns 30, 40 caras para andar aqui (Caio Youssef, entrevista em 15 de abril de 2010, grifos meus).

A partir do exemplo citado por Caio Youssef, percebe-se que o "Ibira" é freqüentado por skatistas de toda a região metropolitana de São Paulo, embora aqueles que morem na Zona Sul da cidade sejam os mais freqüentes:

O dono do palco é de São Caetano. Tem cara da Vila Mariana. Cara da Zona Leste, que é mais de duas horas para chegar aqui dia de trânsito. Tem cara da Sul. A maioria dos caras que colam aqui, a maioria é da Zona Sul: Santa Amaro, Interlagos, e outros lugares. Porque pegam o ônibus ali na 23 [Avenida 23 de Maio] e vêm rápido (Caio Youssef, entrevista em 15 de abril de 2010).

A freqüência de skatistas que vão ao "Ibira" varia conforme o dia e seu respectivo período. Geralmente é no final de semana à tarde que o local recebe maior número de skatistas, que se espalham por toda a marquise. Alguns locais, que fazem do espaço o principal pico para a prática, sabendo da eventual lotação, tentam evitá-la, freqüentando o parque em horários alternativos:

Dia de semana cola bem menos gente. Dia de semana as pessoas trabalham, estudam. Aí é difícil vir os locais, vir gente agora à tarde. Não tem muito esta não. Fim de semana cola mais gente e mais gente diferente (Caio Youssef, entrevista em 15 de abril de 2010).

Se você já foi domingo à tarde, você já viu que é impossível a prática. Então quem anda lá, já está ligado nos horários que lota e não lota, do horário que 
vai estes malucos que "remam" que nem loucos e atropelam todo mundo, dos caras de bike que começam a empinar. Então os caras já estão ligados. Vão domingo depois das 20 horas. Depois que foi todo mundo embora, fica só uma galera jogando hóquei e uns moleques andando. Como se fosse uma galera que andasse um pouco mais séria. E tem também uns caras que vão lá quando chove. Choveu: Ibira! (Raphael "Pezão", entrevista em 29 de março de 2010).

Devido à escassez de espaços cobertos que possibilitem a prática do skate em dias chuvosos, muitos streeteiros encontram na marquise a solução para parte de seus problemas. Com efeito, durante esses dias, o parque também é bastante freqüentado. Todo o espaço do amplo chão liso fica, em certa medida, pequeno para tantos praticantes. Sobre isso, Caio comenta:

Fim de semana à tarde e dia de chuva é difícil. Tem fim de semana aqui que não dá nem para andar. Teve uns tempos atrás que eu nem vinha aqui direito. Vinha mais à noite porque era muita gente. (...) [A marquise] é a salvação nos dias de chuva para os caras. Para mim, não. Eu venho até aqui até quando tem sol. É da hora. Maior ventinho bom. Para fazer uma sessão de leve, um solo, botar umas no pé. É um pico legalize. Se vier com um palco então, não precisa nem de outro pico (Entrevista em 15 de abril de 2010).

De modo geral, os skatistas locais optam por ir ao parque muitas vezes na parte da noite. Essa é uma maneira de distinguirem-se, pois nesse período não há tanta presença daqueles que andam por "moda", dos principiantes, nem daqueles que só vêm ao parque em dias chuvosos. Desse modo a prática se restringe a poucos, que aproveitam os momentos de encontro para criar formas de sociabilidade e ampliar as relações estabelecidas. No entanto, a construção desta sociabilidade não implica em restringir os relacionamentos apenas entre aqueles que mais freqüentam o parque:

A galera com quem eu ando, nós somos locais daqui. A gente sempre anda aqui e recebe os outros de braços abertos. Aqui é um local público e eu não vou poder chegar para o maluco, olhar para ele e falar: "mano, não gostei de você, pega e saí fora”. Isso não existe. Cara que faz isso é otário. A galera que eu ando é tudo da mesma idade, todo mundo tem noção das coisas que faz. Tanto que nunca teve problema nenhum com skatista, um fazer cara feia 
para o outro. Pelo contrário, a gente quer mais que venha todo mundo, ande junto. A gente quer ver o skate unido. A gente quer fazer as coisas pelo skate (Caio Youssef, entrevista em 15 de abril de 2010).

Portanto, muitos skatistas optam por vir ao "Ibira" não só para fazer um solo e manter o "skate no pé", como também, para encontrar conhecidos, vivenciar experiências conjuntas e atualizar diversos tipos de informações:

[O Parque do Ibirapuera] é um lugar onde não tem prédio do lado, você vê mulher o tempo todo, chão lisinho, luz até meia noite. É um lugar onde você vai, se tiver de saco cheio de andar, se tiver com dor nas pernas, senta ali, vai ter uma galera sentada com você. É um ponto de encontro, um lugar gostoso de estar, de aprender manobras novas (Victor Ferrari, entrevista em 16 de abril de 2010).

Quando eu quebrei o braço, eu fiquei três meses sem andar. Eu vinha aqui direto. Eu não podia nem dirigir, então eu pegava ônibus, ficava 1 hora só para vir. Às vezes o cara vem nem de skate, só para passear. Para ficar aqui. Aqui é um parque, é muito grande, dá para fazer tudo (Caio Youssef, entrevista em 15 de abril de 2010).

Às vezes é assim: como o "Ibira" é grande, a gente se conhecesse, a gente está sempre ali. Mas um fica andando, outro sentado, outro fumando um cigarro. Não fica todo mundo junto o tempo todo. Não é que nem no "Vale". No "Vale", como é menor, fica todo mundo junto. No "Ibira" fica mais espalhado (Raphael "Pezão", entrevista em 29 de março de 2010).

Além disso, devido ao fácil acesso até o parque ${ }^{250}$, o mesmo se constitui como uma referência para os streeteiros que pretendem circular pela cidade à procura de outros picos. Marca-se um horário, um local, e a partir do encontro todos vão juntamente para outras regiões da cidade:

O que a gente mais faz é vir para cá de sexta à noite, depois da aula, encontra aqui e dá um "rolê" até umas 11. Depois que apaga as luzes, todo mundo sobe para a Paulista e fica andando lá de madrugada (Caio Youssef, entrevista em 15 de abril de 2010).

250 Várias linhas de ônibus da região metropolitana de São Paulo passam próximas ao Parque do Ibirapuera. Além disso, este parque não se encontra tão longe de algumas estações de metrô. 
Mas lá a galera é bem mais unida. Lá e o "Vale" né. Lá tem uma galera que cola sempre junto, que sempre cola junto em todos os eventos. Mesmo fora dali virou um círculo social. É uma galera que sempre faz o "rolê" junto (Raphael “Pezão", entrevista em 29 de março de 2010).

Com base no que foi apresentado até aqui, é possível notar como a prática do street skate no "Ibira" aproxima-se ora daquela encontrada no "Vale", ora daquela encontrada em pistas. Em relação ao "Vale" aproxima-se tendo em vista a centralidade do local na cidade, o qual se torna um ponto de referência onde se estabelecem formas de sociabilidade entre diferentes skatistas. Já em relação às pistas aproxima-se por ser um espaço de aprendizado para aqueles que queiram experimentar a prática do skate, embora também não seja relevante - de acordo com os discursos construídos - andar somente no mesmo.

\subsection{2 - "Rolê" no Parque do Ibirapuera}

Vários skatistas com os quais tive contato ao longo desta pesquisa andam de skate no Parque do Ibirapuera. Porém, uns com mais regularidade - os locais -, e outros, nem tanto. Seja com maior ou menor frequiência, é perceptível a importância atribuída a esse parque por meio dos discursos construídos em torno da modalidade street skate. Portanto, eu não podia deixar de visitá-lo. Durante o mês de abril de 2010, após constantes idas ao Vale do Anhangabaú, recebo o convite de alguns skatistas - como Jorge Costa, Victor Ferrari e Raphael "Pezão" - para encontrá-los no mencionado parque. A partir dessas oportunidades passei a acompanhá-los em suas respectivas práticas embaixo da marquise, através de idas em diferentes dias e horários, como as que serão apresentadas neste tópico.

Em plena tarde de uma sexta-feira, recebo a ligação de Jorge Costa. Ele me disse que à noite iria ao Ibirapuera, para fazer uma sessão junto de alguns amigos. Caso eu quisesse, poderia acompanhá-lo. Por volta das 20 horas, saio de casa. Após um considerável percurso, chego ao meu destino. Estava chovendo e fazia frio. Logo, diversas áreas abertas do parque estavam completamente vazias. Quanto mais eu andava, mais o local tornava-se deserto. Inclusive, cogitei a possibilidade de não haver ninguém na marquise. Após uma longa caminhada, todavia, ouvi barulhos diferentes. 
Eles pareciam provenientes da madeira dos shapes, que batiam no chão. A partir desse sinal, percebi que em algum lugar estavam os skatistas. Coloquei os meus óculos e de longe avistei alguns deles, circulando rapidamente embaixo da parte mais iluminada da marquise. Havia em torno de trinta praticantes, que se dividiam por diversos espaços.

Jorge Costa ainda não havia chegado. Enquanto isso aproveitei para reparar um importante detalhe: em meio à extensa marquise, o local que os streeteiros possuem como referência para encontro é chamado de "aranha". Trata-se de um espaço próximo à escultura de uma enorme aranha, exposta nas imediações do Museu de Arte Moderna $^{251}$. Em frente a ela, os praticantes se reúnem para tentar conjuntamente as suas manobras.

Próximo aos banheiros, para minha surpresa, encontrei vários skatistas locais do Vale do Anhangabaú, dentre eles: Tiago Garcia, Fábio Brandão, Renan Hassan, "JN" Charles e André Manto. Eles tinham vindo ao Parque do Ibirapuera devido à chuva que caía, a qual impossibilitava a prática do skate em muitos picos do centro da cidade. Aproximei-me deles e, após cumprimentá-los, observei que jogavam o game of skate ${ }^{252}$. Esse é um jogo bastante praticado entre os streeteiros, a fim de aperfeiçoarem as técnicas de suas manobras feitas no solo. Como esse tipo de pico é abundante no espaço da marquise do "Ibira", o jogo citado é um dos passatempos prediletos por parte daqueles que ali praticam. O game of skate é praticado por, no mínimo, dois skatistas. Cada jogador deve mandar uma manobra. Se errá-la, a vez passa para o outro. Mas caso acerte, todos os demais também devem tentá-la. Se a tentativa for frustrada, o skatista recebe uma letra da palavra "skate". Por exemplo: o skatista André Manto manda uma manobra, chamada frontside flip. Porém, os skatistas Renan Hassan e "JN" Charles erraram-na. Logo, eles recebem a letra "s". Se errarem as próximas manobras receberão, sucessivamente, as letras "k", “a”, “t” e "e". Com efeito, aqueles que completam a palavra "skate" são desclassificados. Dessa maneira, o vencedor é aquele que acerta o maior número de manobras possíveis, e que não completa com as letras a referida palavra. Através de jogos, como este, os streeteiros colocam "o skate no pé" e aprendem novas manobras em cima do "carrinho".

\footnotetext{
251 A "aranha", ou melhor, Maman (nome atribuído à escultura) é uma obra da escultora francoamericana Louise Bourgeois. Para mais informações: http://plasticamente.wordpress.com/2008/04/24/aescultora-da-aranha-gigante/.

${ }^{252} \mathrm{O}$ game of skate se tornou famoso em todo mundo após a És Footwear, marca norte-americana de tênis, promover alguns eventos com formato parecido.
} 
Enquanto os skatistas jogavam o game of skate, Tiago Garcia somente os observava. Ele não tinha levado seu skate, pois estava com o pé machucado. Mesmo impossibilitado de praticar, esse skatista faz questão de acompanhar seus amigos nas sessões realizadas. Em dado momento, passou a folhear uma revista de skate. Concomitante a isso, estabelecemos uma conversa, tendo como assunto a mídia especializada. Ele fez algumas críticas à forma que ela trata a prática do skate: em vez de abordar aquilo que chama de lado for fun, parece que os envolvidos com a mídia escrevem matérias somente para quem está atrás de mesas de escritórios, de terno e gravata ${ }^{253}$. Segundo Tiago, a prática do skate é muito mais que esta suposta seriedade passada por meio de algumas revistas. Ela é, acima de tudo, uma "diversão". Portanto, é preciso ter ousadia ao fazer as matérias. Para concluir sua idéia, Tiago a comparou com algo recorrente neste universo. Certo dia um garoto estabeleceu uma conversa online com ele. Ao saber que atua a frente da marca Future Skateboards, o referido garoto, que também é skatista, disse que estava à procura de patrocínios, e por isso, andava de skate todos os dias e tentava captar imagens, a fim de fazer um material de divulgação de seu nível técnico. Tiago discordou do garoto, e disse ao mesmo que conseguir patrocínios e seguir carreira enquanto skatista profissional é um processo "natural". Portanto, de acordo com o ponto de vista desse interlocutor, a "diversão" com o skate é essencial e não deve ser perdida.

Próximo a Tiago Garcia também estava Victor Ferrari, local do "Ibira", o qual eu havia encontrado dias atrás no Centro. Ele relacionava-se com os locais do "Vale" presentes no parque, embora com certa reserva. Tanto é que ele não participava do game of skate que ora se estabelecera. De outro modo, Victor demonstrava ser mais próximo de Daniel Santi, skatista que estava em sua companhia e que também é local do "Ibira". De modo geral, esse encontro entre skatistas locais do "Vale" e do "Ibira" reverbera as redes de relações que se cruzam entre os streeteiros da cidade de São Paulo, bem como a sociabilidade que se alarga a partir da circulação por vários picos.

Após algum tempo, Jorge Costa chegou ao parque. Ele atrasou-se, pois teve que ir à casa de um amigo vender algumas peças de skate. O skatista deixou sua mochila encostada em uma pilastra e, em seguida, foi andar de skate. Como aquela noite estava fria, ele queria dar uma "esquentada" no corpo. Enquanto andava, reparei que as sessões de skate no "Ibira" podem ser feitas de diferentes maneiras, dependendo da criatividade.

${ }^{253}$ Essas pessoas de terno e gravata a quem Tiago Garcia se refere são os anunciantes das revistas. 
Alguns skatistas optam por ficar durante um considerável tempo tentando acertar uma só manobra. Ao contrário, há também aqueles que visam acertar uma linha, isto é, uma sequiência de manobras diferentes. E também, aqueles que elaboram diversos tipos de brincadeiras, como o "pega-pega de skate" ou a "corrida de skate", que não levam em conta o exercício de manobras.

Já eram quase 22 horas. O número de skatistas presentes na marquise diminuiu consideravelmente. Só restaram os que esperavam pelo obstáculo improvisado que estava prestes a chegar. Em dado instante algumas pessoas colocaram um palquinho de madeira no solo. Sabendo dos horários que concentram a maior presença de skatistas, esses praticantes estrategicamente optam por aqueles em que não há tanto movimento, podendo assim andar de skate mais tranqüilamente. Por isso, quanto mais tarde, maior a probabilidade da marquise estar vazia.

Jorge Costa andava de skate próximo a Willian Damascena. Esse último esteve presente em várias etapas do Circuito Sampa Skate, conquistando, inclusive, boas colocações no ranking final. Após parar de praticar, Jorge me chamou para acompanhálo até o palquinho, pois queria me apresentar a um skatista local do "Ibira". Com isso, conheci Caio Youssef, streeteiro que anda regularmente neste espaço. Conversamos durante um tempo e marcamos novos encontros, para que ele me apresentasse mais um pouco da prática do street skate embaixo da marquise.

Depois desta ida ao "Ibira" no período da noite, retorno ao parque no dia seguinte, porém à tarde. Era um sábado. Como Jorge Costa não iria, optei por ir sozinho. Certo do local onde os skatistas se reúnem, desta vez não tive dificuldade em encontrá-los. Assim que entrei no espaço da marquise, observei uma série de diferenças em relação ao dia anterior. Como era fim de semana, o parque estava lotado. Enquanto caminhava, presenciei casais de namorados, jogadores de futebol americano, traceurs ${ }^{254}$, b-boys ${ }^{255}$, rollers ${ }^{256}$, bikers, e também, em maior número, skatistas. Contudo, nem todos skatistas eram streeteiros. Dentre eles também havia os freestylers ${ }^{257}$ e os longboarders. Cada um dos presentes disputava certos espaços do chão liso, para realizar suas respectivas práticas favoritas. Desse modo, neste contexto há certas divisões simbólicas e

\footnotetext{
254 Traceurs são os praticantes do le parkour.

255 B-boys são aqueles que praticam um tipo de dança chamada breakdance.

256 Rollers são os praticantes dos patins in line.

257 O Parque do Ibirapuera também possui uma importância especial para a modalidade freestyle do skate. Devido ao seu solo, muitos praticantes do estilo livre se dirigem até lá, para aperfeiçoarem as habilidades próprias da modalidade.
} 
territoriais que identifica cada espaço como sendo relacionado a um tipo de prática específica.

Próximo à "aranha", vários streeteiros mandavam suas manobras no solo. Como o local estava cheio, estavam atentos aos seus movimentos, a fim de evitar choques físicos com outros praticantes. Aqueles skatistas que não andavam, permaneciam sentados e encostados em uma parede. Entre uma conversa e outra, levantavam e voltavam a andar um pouco mais de skate.

De repente, alguns streeteiros chegaram com caixas de papelão. Eles as colocaram no solo, para tentar pulá-las; logo, muitos outros presentes tentaram fazer o mesmo. Aquelas simples caixas tornaram-se o foco para muitos praticantes, que disputavam, mesmo que indiretamente, a realização da manobra mais difícil. Esta, por sua vez, quando acertada era aplaudida pelos demais.

Conforme apresentado anteriormente, o "Ibira", por ter um espaço propício para o exercício de manobras no solo, é freqüentado por muitos daqueles que estão iniciando a prática do skate. E é durante os finais de semana, principalmente na parte da tarde, que vários deles se reúnem na marquise. Ao caminhar pelo local observei diversas garotas, crianças, jovens e até mesmo pessoas mais velhas, tentando se equilibrar em cima do skate. Não obstante, ao tomar como ponto de referência a "aranha", percebe-se que os streeteiros dotados de um maior nível técnico ocupam os espaços centrais, ao passo que aqueles que não sabem tantas manobras, ficam em espaços mais afastados.

Ao chegar o período noturno, muitos skatistas foram embora. Aquele intensa circulação de praticantes aos poucos deu lugar a uma certa calmaria. E é neste momento que começaram a surgir os locais. Cientes dos horários mais vazios, eles fazem suas sessões no solo, tendo em vista também, o encontro com outros streeteiros. Por fim, esses citadinos compartilham experiência com outros que fazem do "Ibira" um espaço não só para a prática do skate, como também, para o exercício de uma sociabilidade mais densa. É válido ressaltar que o parque constitui, em muitos casos, o ponto de chegada ou de partida para as sessões realizadas em outros picos da cidade; portanto, para alguns skatistas, "o 'rolê' começa aqui ou acaba aqui”, ${ }^{258}$, resumiu Caio Youssef.

Após apresentar relatos de algumas idas a campo, é possível perceber como a dinâmica em torno da prática do street skate no Parque do Ibirapuera se altera conforme o dia e o horário. Este local se constitui enquanto espaço central para a prática do skate,

258 Conforme observado, por exemplo, muitos vão da Avenida Paulista ao parque ou se dirigem do mesmo até ela. 
embora cada um dos freqüentadores atribua uma importância diferenciada ao mesmo, a qual se reflete em suas interações, e também, em suas apropriações de certos picos presentes no parque.

\section{ICONOGRAFIA - CAPÍTULO II}

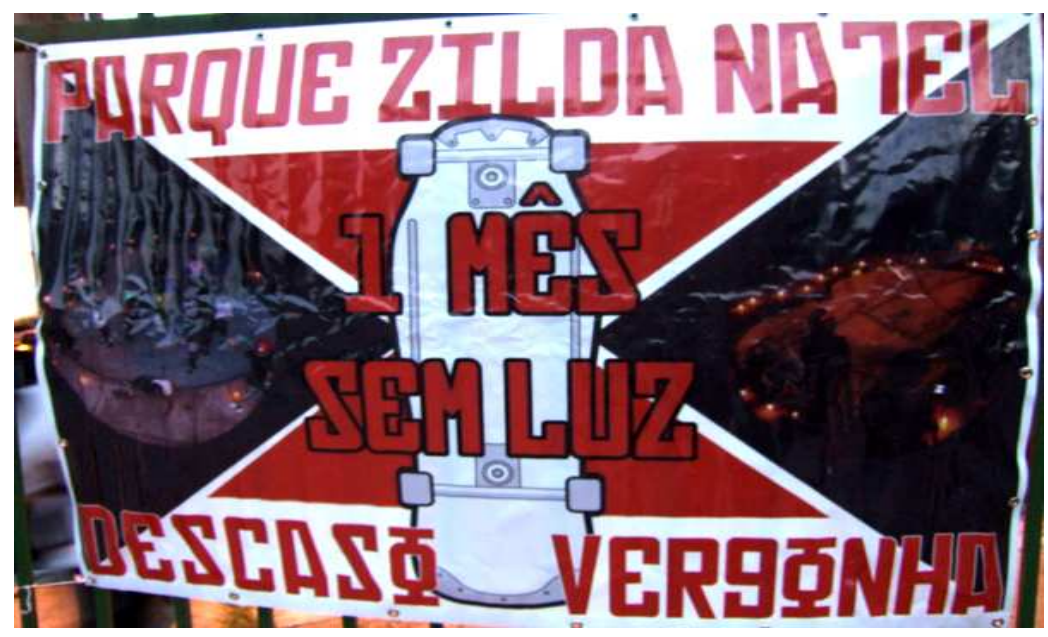

Banner protesta contra a falta de luz no Parque Zilda Natel (foto: G. Machado)

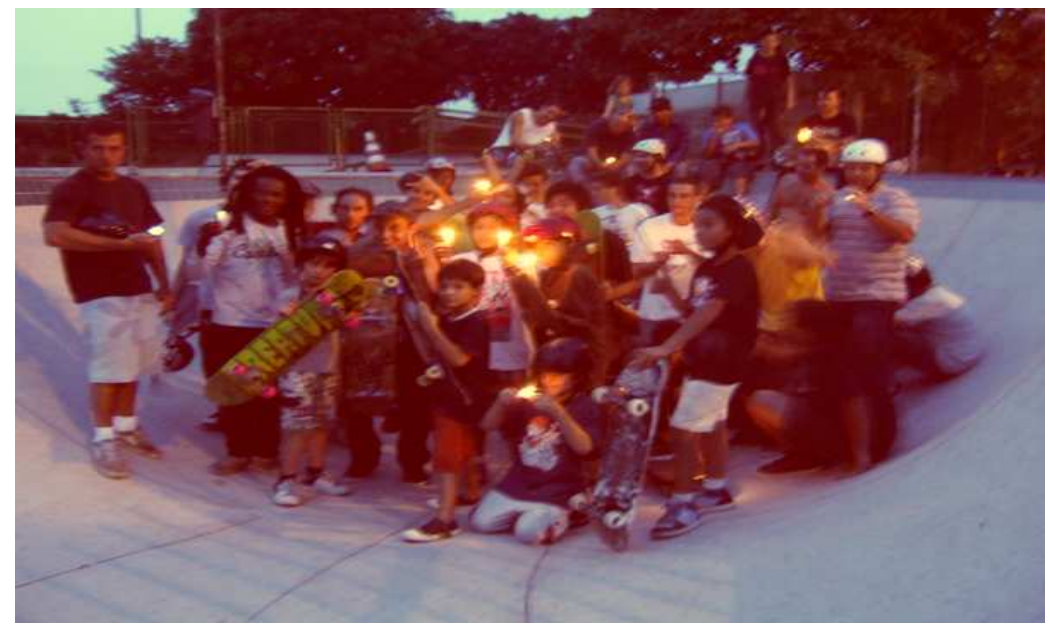

Skatistas seguram velas em protesto (foto: G. Machado) 


\section{ORIENTAÇÕES GERAIS}

1 - Skate é um esporte perigoso, com risco de acidentes;

2. O uso do equipamento de proteçāo individual (capacete, joelheiras, cotoveleiras e tênis) é extremamente recomendado;

3 - Respeite seus parceiros de sessão;

4 - Tenha consciência de seu nível técnico;

5 - Muita atenção com os outros usuários do parque;

6 - Informaçōes sobre cada pista do parque de skate, ou seja, o banks, a área de street e a mini rampa;

7 - $\mathrm{O}$ aquecimento e $\mathrm{o}$ alongamento são práticas importantes para evitar ou prevenir lesōes:

8 - Consulte o regulamento completo na administração do Parque.

Orientações gerais para a prática do skate na pista do Sumaré

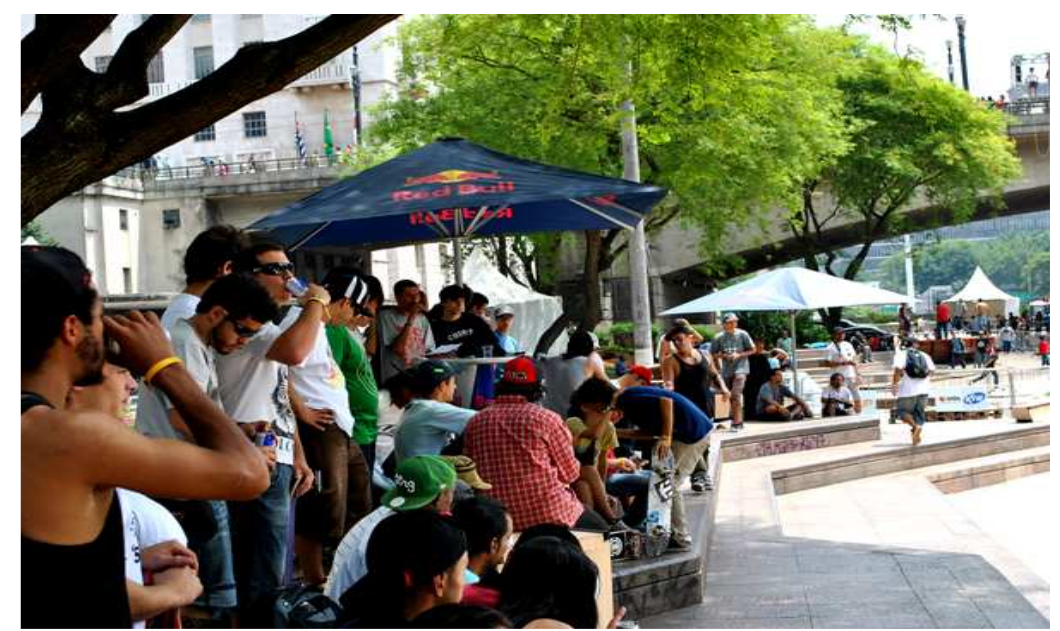

Skatistas reunidos nas escadas do Vale do Anhangabaú (foto: G. Machado)

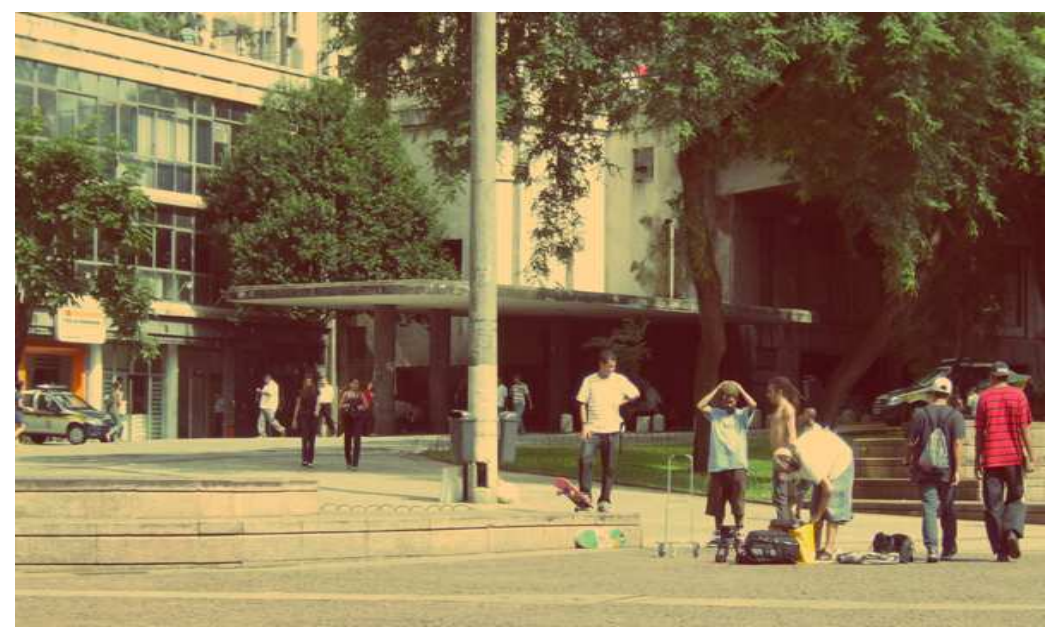

O Vale do Anhangabaú é um ponto de encontro para skatistas de todas as partes da cidade de São Paulo (foto: G. Machado) 


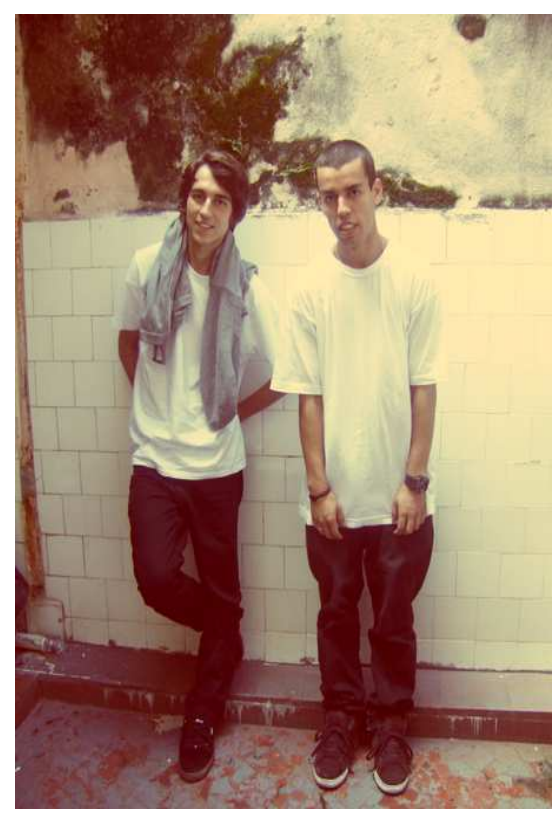

Marcelo "Dohdoh" e Rodrigo "Bocão" (foto: G. Machado)

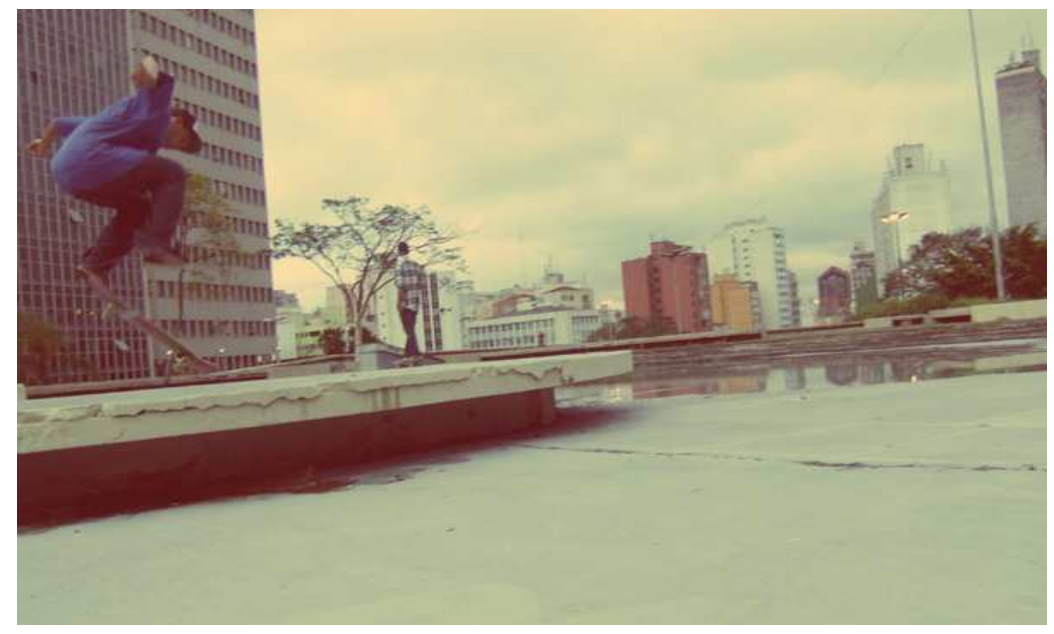

Skatista realiza manobra em um dos picos da Praça Roosevelt (foto: G. Machado)

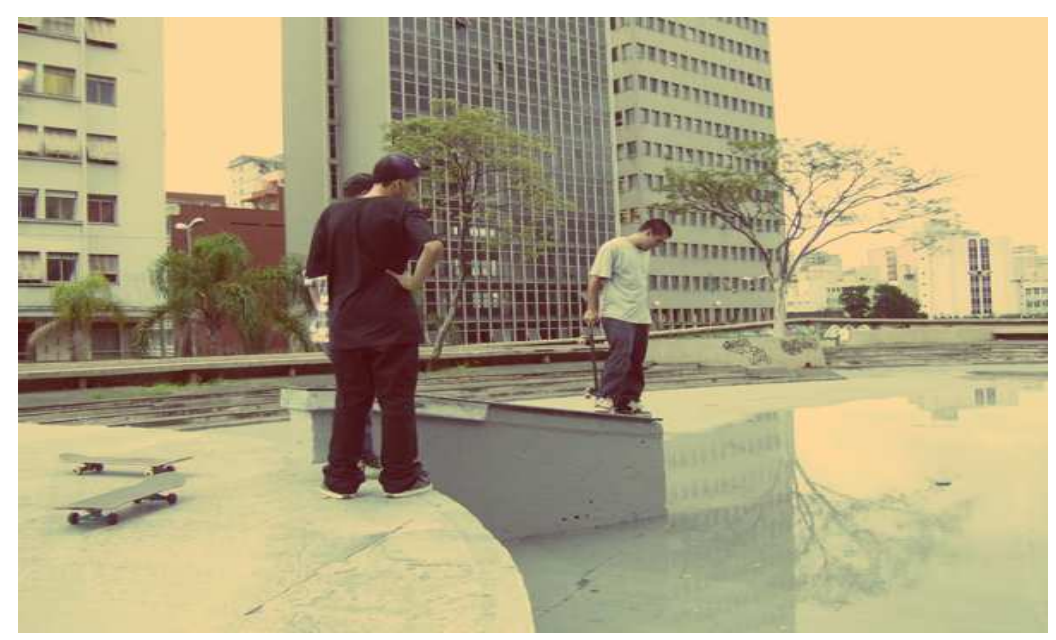

Skatistas observam um pico construído por eles na Praça Roosevelt (foto: G. Machado) 


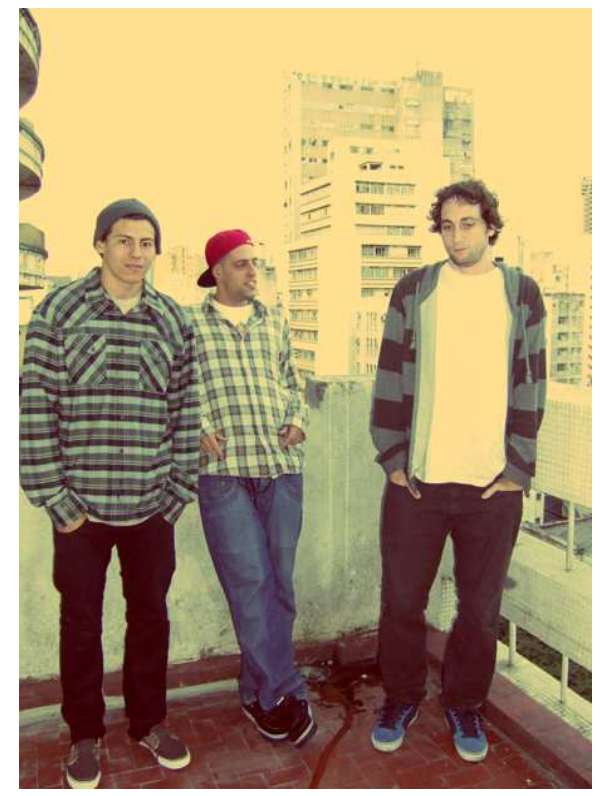

Da esquerda para direita: o fotógrafo Fellipe Francisco, e os skatistas Tiago Garcia e Fabio Brandão, no escritório da Future Skateboards (foto: G. Machado)

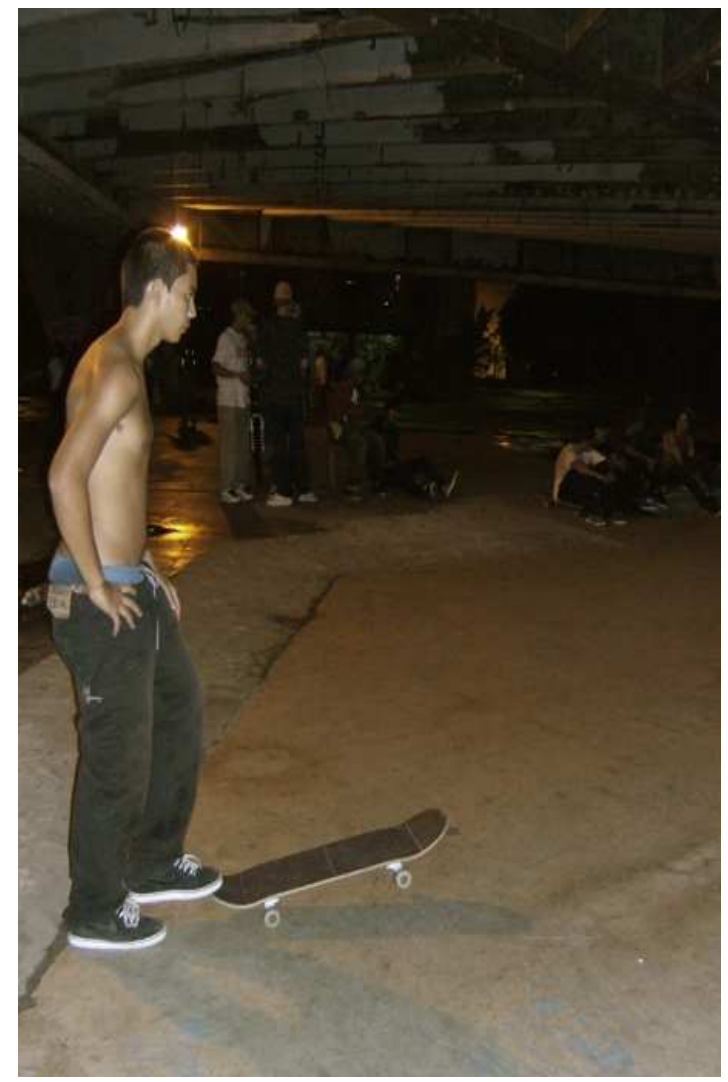

Em dias chuvosos, um dos lugares em que os skatistas se encontram no centro da cidade é um espaço coberto localizado na Praça Roosevelt (foto: G. Machado) 


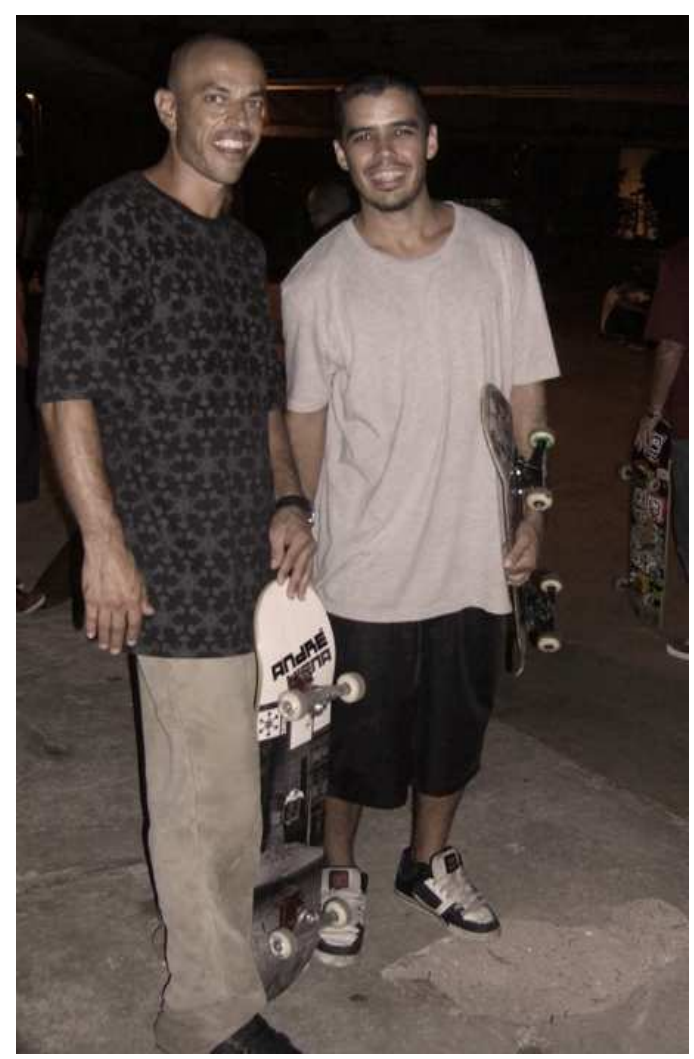

O skatista profissional André Hiena e Alexandre "Nicolau” (foto: G.Machado)

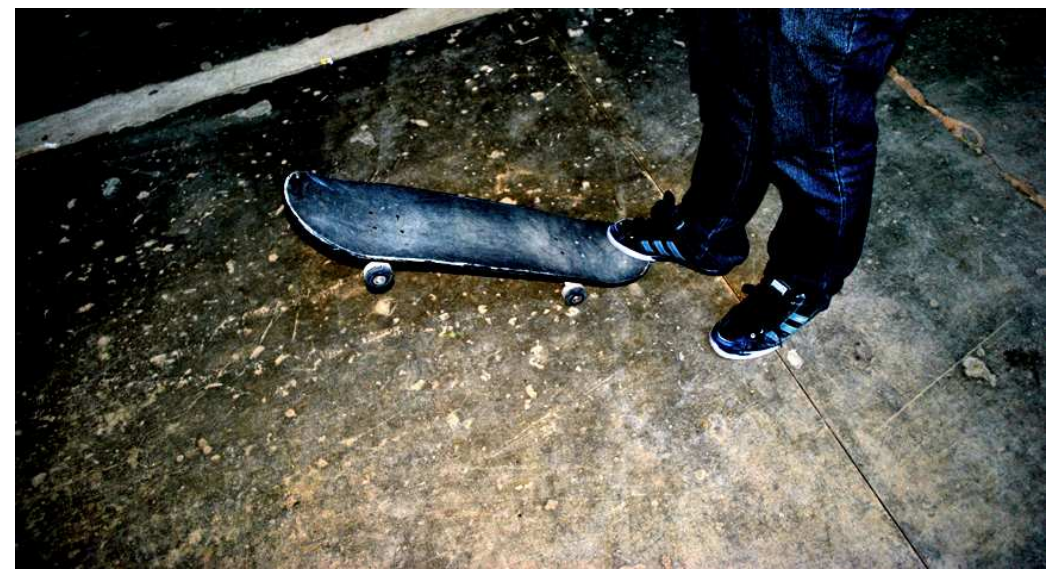

Skate no Parque do Ibirapuera (foto: G. Machado) 


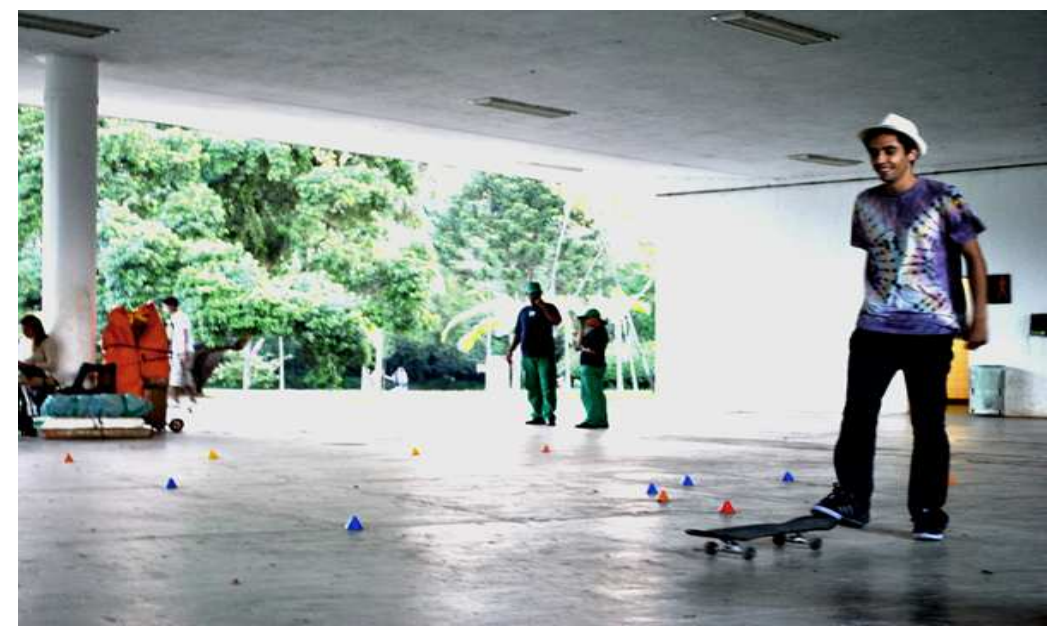

Caio Youssef se prepara para mandar uma manobra no solo do Parque do Ibirapuera (foto: G. Machado) 


\section{Capítulo III - Skate na cidade, imagens da cidade}

\section{1 - Sessões em picos privados}

A cidade de São Paulo possui uma quantidade incalculável de picos espalhados por todas as suas regiões. Seja em áreas periféricas ou centrais, é possível encontrá-los facilmente; entretanto, conseguir fazer uma sessão bem sucedida em muitos deles não é tão simples assim. Em locais públicos, como o Vale do Anhangabaú e o Parque do Ibirapuera, a prática do street skate está consolidada há muitos anos. Portanto, a presença de skatistas com seus respectivos "carrinhos" é familiar para os outros citadinos que freqüentam esses lugares. Como, então, os streeteiros utilizam certos espaços da cidade que, inicialmente, foram projetados ignorando a constituição de formas de sociabilidade e muito menos o exercício de uma prática esportiva?

Quando ouvimos algo relacionado à Avenida Paulista, diversas imagens vêm à nossa mente de forma tão intensa que poderíamos listar, durante um bom tempo, uma pluralidade de coisas possíveis de se ver e se experimentar por lá: trânsito intenso, passos acelerados, pessoas de terno e gravata, prédios comerciais, museus, manifestações políticas, artistas de rua, vendedores ambulantes, policiais, fast-foods... Mesmo diante tamanha heterogeneidade, falar em uma prática esportiva feita no local poderia soar, inicialmente, como algo incabível. E foi essa a sensação que tive quando fui convidado a presenciar uma sessão de skate em uma das avenidas mais movimentadas do país ${ }^{259}$.

A Avenida Paulista tornou-se um dos locais mais freqüentados pelos praticantes do street skate nos últimos tempos. Isso se deve, em boa medida, à substituição de seu piso de pedra portuguesa por outro de superfície mais lisa. A partir dessa reforma, as rodinhas dos skates puderam circular pelas largas calçadas da avenida, disputando cada espaço com milhares de outros citadinos que também transitam por lá diariamente.

Juan Aliste, skatista chileno, esteve no Brasil por conta de sua participação em um evento promovido pela marca que o patrocina ${ }^{260}$. Como estava hospedado em um hotel

\footnotetext{
259 Frúgoli Jr. (2000) realça em sua pesquisa a condição de centralidade adquirida pela Avenida Paulista ao longo do tempo, a qual se tornou um "símbolo" da cidade de São Paulo. Esse fato evidencia uma estratégia no sentido de maximizar o prestígio de um espaço já consagrado. Mais detalhes a respeito das centralidades da cidade de São Paulo, sejam elas históricas, culturais e empresariais, vide Frúgoli Jr. (2000).

${ }^{260} \mathrm{O}$ evento em questão é o DC King of São Paulo, que será detalhado nos próximos tópicos.
} 
localizado nas imediações da Avenida Paulista, não quis perder a oportunidade de conhecer diversos lugares skatáveis paulistanos. Para que isso ocorresse, o fotógrafo Fellipe Francisco entrou em contato com o referido skatista, e ambos combinaram uma sessão de skate em um dos picos da avenida. Tive a chance de presenciar o encontro, no qual foram produzidas algumas fotos para uma matéria posteriormente publicada na Revista Tribo Skate.

Andar de skate na Avenida Paulista não é uma tarefa fácil. Vários fatores dificultam a prática nos picos encontrados por lá. Um deles é a intensa circulação de pessoas nas calçadas. Diante adversidades como essa, os skatistas precisam aderir a uma série de estratégias, visando minimizar possíveis dissabores. Na sessão que presenciei, ficou combinado que o encontro entre os participantes se daria próximo à meia-noite, pois, com o fechamento das estações de metrô, o fluxo de pedestres diminui consideravelmente.

Após encontrar o skatista e fotógrafo Marcelo "Mug", fomos até o pico em que a sessão seria feita: as escadas do Banco Central. Chegamos ao local e já havia alguns skatistas, não conhecidos por mim, circulando de um lado para o outro na extensão da calçada. Eles não ficavam muito tempo parados nos picos encontrados. Ora andavam no wallride do Banco Central, ora andavam nas quinas de um canteiro da Caixa Econômica. E não se limitavam a isso, pois, com o chão liso, muitos equipamentos urbanos - hidrantes, rampas de acesso a deficientes, guias, bueiros, corrimãos - também viravam obstáculos.

Não demorou muito tempo para que restassem apenas poucas pessoas em frente ao pico em que estávamos. Como aquela noite estava fria, o skatista que seria fotografado precisou fazer um breve aquecimento. Ele então circulava pela calçada, desviando-se das pessoas e mandando algumas manobras no chão. "Mug" não faria fotos naquele momento. Deixando brevemente sua função de fotógrafo, também aproveitou para andar um pouco de skate. Enquanto isso, Fellipe Francisco montava todo seu equipamento em frente às escadas do Banco Central, espalhando os tripés com seus respectivos flashes por vários cantos. O local parecia um estúdio fotográfico ao ar livre.

Depois do breve teste dos equipamentos fotográficos, estava tudo pronto para a sessão. Nesse momento o skate saiu da calçada para adentrar em um espaço com regras privadas (as escadas na porta de um banco). Juan Aliste começou a tentar pular a escadaria em formato double set. Ao observá-lo, notei que ele tomava certos cuidados não só com seu corpo, mas também, com as pessoas que circulavam pelas imediações. É 
preciso cautela para não acertá-las com o skate. Uma série sucessiva de tombos não foi capaz de desanimá-lo. O que importava, pelo menos naquele instante, era utilizar o obstáculo e acertar a manobra, para ter sua foto estampada na página de uma revista especializada.

Durante a sessão, tanto o skatista quanto o fotógrafo estavam ansiosos para realizar, respectivamente, a manobra e a foto. Todavia, havia entre eles uma preocupação com uma possível repressão ${ }^{261}$. A qualquer instante os seguranças do banco, ou até mesmo alguns policiais podiam aparecer e eles não tinham autorização para utilizar o obstáculo. A sessão durou apenas alguns minutos. Para o alívio do skatista e do fotógrafo, passado um tempo a manobra e as fotos foram feitas em uma das “paisagens de poder" (Zukin, 2000) da cidade ${ }^{262}$.

Aquela escada, atravessada por centenas ou milhares de clientes do Banco Central durante o dia, à noite se transformara em um pico para os skatistas, palco de uma memorável sessão fotografada e publicada em uma revista. Isso demonstra, como bem observado por De Certeau $(2009,233)$, que “(...) as maneiras de utilizar o espaço fogem à planificação urbanística". Após a sessão, já de madrugada, eles saíram dali e foram em direção a outros picos, levando em conta a proximidade entre os mesmos na Avenida Paulista. Diante a imprevisibilidade dos usos dos espaços urbanos, nada mais importante para os streeteiros, portanto, que estarem preparados para captar as imagens da conquista de um pico por meio da realização de manobras.

\subsection{1 - Estratégias para sessões em picos proibidos}

\footnotetext{
261 A prática do skate não é permitida nas escadarias do Banco Central, pois há vários seguranças que tentam impedir a realização de manobras nos equipamentos que ficam em um espaço com regras privadas. Por isso há um duplo risco para o skatista: o de se machucar com a prática e o de uma possível repressão por parte de seguranças ou policiais.

${ }^{262}$ A Avenida Paulista pode ser associada ao que Zukin $(2000,106)$ chama de "paisagem de poder", ou seja, um espaço que expressa as restrições estruturais de uma cidade, o que implica na separação e limitação de certas atividades e práticas (como a do skate e tantas outras), que por vezes incorporam e reforçam as diferenças. Ao analisar a produção de uma "paisagem de poder" em torno da Avenida Paulista, Oliveira $(2000,214)$ nos diz que: "ao mesmo tempo em que os pesados investimentos na reelaboração da imagem da Avenida Paulista se revelam eficazes - ao menos parcialmente - em sua intenção de atrair a riqueza e o poder simbolizados pelos grandes investimentos internacionais, essas mesmas transformações do espaço da Paulista e das formas de sociabilidade ali vividas recriam-na como um lugar extremamente interessante para outros atores sociais que, a princípio, não 'cabem' nos conceitos e imagens da globalização". Desse modo, assim como em outras práticas - sendo estas não só esportivas -, os skatistas escolhem a Avenida Paulista como palco de manobras tendo em vista a visibilidade construída em torno da mesma.
} 
Esse relato demonstra apenas uma sessão realizada pelos streeteiros em um dos inúmeros picos encontrados em São Paulo. Conforme visto, praticantes de diversas regiões se dirigem até a Avenida Paulista, situada em uma área central da cidade, com a expectativa de encontrarem diferentes tipos de equipamentos urbanos para suas manobras. Isso nos permite entender os supostos "usos dissonantes dos espaços, não como manifestações de 'desordem', mas como formas singulares de apropriação cotidiana e pública de certos espaços" (Leite, 2006, 23). Desse modo, tais citadinos, por meio daquilo que chamam de olhar skatista, dão novos significados aos espaços a partir de suas experiências.

As intensas mudanças às quais os equipamentos urbanos estão sujeitos fazem com que os picos constantemente apareçam ou desapareçam das cidades ${ }^{263}$. A Avenida Paulista é um caso exemplar. A substituição do piso de pedra portuguesa de sua calçada era o que faltava para que ela se tornasse alvo dos praticantes do street skate:

Só um chão proporcionou tudo isto. Tem muita gente ali que nem imaginava andar de skate um dia na Paulista. Ou nem imaginava andar de skate um dia na vida e só porque criou um chão, imaginou isto. Então, às vezes uma simples reforma, um simples incentivo, por mais inconsciente que seja, vai atrair mais gente. E a notícia corre. Um dia alguém andou. O chão é ruim. Mas aí reforma, rapidinho a notícia espalha e já está "bombando” (Daniel Santi, entrevista em 16 de abril de 2010).

Os consideráveis obstáculos encontrados fazem da avenida aquilo que os streeteiros sempre almejaram, ou seja, um espaço com muitos picos concentrados próximos aos outros, condição que permite a uma sessão ser feita de forma contínua:

Vários picos em um mesmo lugar, apesar de não ser fácil de andar em todos os lugares. Mas a gente aproveita do melhor jeito possível. Quem não gosta de skate, odeia ir à Paulista no final de semana, porque tem muito skatista. [Mas] gente que nunca andou de skate pega o filho e vai andar de skate, dar uma volta. O chão liso proporciona tudo isto. Geralmente todo mundo se encontra no wallride. Às vezes encontra até sem combinar. Combina com dois, daí chega mais dois. E a partir dali vai indo para outros lados: tem a

263 Muitos interlocutores me disseram ficar atentos às reformas e às novas construções de equipamentos urbanos, pois a partir das mesmas podem surgir picos que possibilitem a prática do skate e, conseqüentemente, a captação de imagens inéditas. 
borda de mármore do Bradesco, tem o buraco na pracinha em frente à Paulista, tem o banco curvo. Tem pico que não acaba mais. Tem a double set, gap, corrimão (Victor Ferrari, entrevista em 16 de abril de 2010, grifos meus).

O legal da Paulista, o que eu acho que fez tanto sucesso, é porque ela é um sonho americano. É você chegar, jogar o skate no chão e sair remando. Dá uma manobra aqui e continua remando. Atravessa, vai embora remando. Aqui em São Paulo não tinha isto. É quase $1 \mathrm{~km}$ e pouco e dá para você sair remando. Dá para fazer um "rolê" gostoso, tipo aquele street que você vê nos vídeos e pô: “onde eu faço isso, mano?” (Raphael "Pezão", entrevista em 29 de março de 2010).

Enquanto certos espaços públicos, como Vale do Anhangabaú, Parque do Ibirapuera e algumas pistas se configuram como lugares onde se estabelecem formas de sociabilidade mais densas, espaços com equipamentos privados que possibilitam a prática do skate propiciam o foco voltado, sobretudo, para a circulação e realização de manobras. Em função disso, a utilização de picos cujo acesso é proibido é feita de forma rápida. Isso se deve, em boa medida, às formas de repressão encontradas no local, pois quanto maior o tempo de prática do skate, maior a possibilidade de atritos com seguranças, guardas ou policiais.

Embora a maioria de seus picos seja privada ${ }^{264}$, a Avenida Paulista é considerada atrativa pelos skatistas, pois nela podem mandar suas manobras em um dado equipamento e, em seguida, sair daí rapidamente. Como há vários picos próximos, feita a sessão, eles podem ir à procura de outros. Com isso é possível testar a técnica em diferentes obstáculos, que contam com distintos níveis de dificuldades e riscos ${ }^{265}$.

A permanência de skatistas na Avenida Paulista, assim como em muitos outros picos privados da cidade, pode ser vista como efêmera ${ }^{266}$. Com efeito, os próprios

\footnotetext{
264 A expressão picos privados faz referência aos equipamentos urbanos situados em espaços cujas regras de circulação e de acessibilidade são privadas, tais como: escadarias na porta de bancos, corrimãos de prédios comerciais, quinas de mármore nas calçadas de comércios, etc.

265 A proximidade entre os picos é um diferencial da Avenida Paulista em relação a muitos outros espaços da cidade. Isso possibilita com que o skatista possa andar, por exemplo, em desde um simples banco de madeira até em um alto corrimão fixado em uma escadaria.

266 A maioria dos referidos picos é privada, o que impede os skatistas de permanecerem tanto tempo nos mesmos.
} 
interlocutores, durante nossas conversas, dificilmente conseguiam identificar alguém como sendo local de lá ${ }^{267}$ :

Todo mundo de São Paulo anda na Paulista. Tem muita gente que vem de fora para andar na Paulista. Mas não tem uns locais mesmo da Paulista. É difícil [um skatista] ir e andar todos os dias ali. Mas a Paulista não é um lugar que toda hora pode andar. Então, é mais de madrugada. Quem anda todo dia no mesmo lugar de madrugada? Ninguém (Victor Ferrari, entrevista em 16 de abril de 2010, grifos meus).

Teve uma época que virou quase um "Ibira". Toda segunda-feira a gente se encontrava lá para andar depois das 21 horas. Sempre à noite. Porque de dia é inviável você andar até de bike lá. Mas o "rolê" na Paulista não chegou a ser tanto assim. São mais estes moleques com quem eu ando hoje, que a gente se encontrava lá. Não cheguei a fazer amigos. Lá é um pico onde cola de tudo, e não tem uma galera específica: "olha, eu sou local da Paulista!” (Raphael “Pezão", entrevista em 29 de março de 2010, grifos meus).

Em sua busca por picos para andar de skate, Raphael "Pezão" tenta reduzir os possíveis problemas oriundos da prática. Porém, para esse interlocutor, há vários skatistas que utilizam os equipamentos não com o propósito de somente praticar, mas ao contrário, para promover badernas que incomodam outras pessoas. Tais atos, de uma certa forma, não se associam a um único praticante, mas sim, aos skatistas em geral, o que contribui para que uma má imagem seja construída em torno dos streeteiros:

Na Paulista é aquilo que você vê: ou é uma galera que anda sério de skate,
isto é uma galera mesmo. Ou é aquela molecada. Não vou dizer que não é
sério. Mas é aquela molecada que começou agora. Eu vejo isto porque eu
morei lá por muito tempo. E eu via da janela: a molecada não tem muita
noção, está se achando ainda no mundo, só que lá vai e "mama" com aquela
galerinha da Augusta e sai que nem louco. Mas isto não é um, nem dois. É
uma galera. Não vou por a culpa só neles. Mas são uns caras que atropelam
um monte de gente, uns caras sem noção. Minha tia uma vez reclamou:
"moleque veio na minha direção. Não me viu. Se eu não desvio, ele me
atropela". Eu falei: "poxa, tia, eu não faço isto. Eu tenho noção do meu

267 É de se ressaltar ainda que a Avenida Paulista é freqüentada por muitos locais do "Vale" ou do "Ibira", que freqüentemente vão até a mesma para dar continuidade às suas sessões. Com efeito, conforme apontado por Raphael "Pezão", nesta avenida "não tem uma galera específica". 
espaço”. Mas para quem não anda de skate, é tudo skatista! Eu achei que isto foi foda para o skate. Porque no Ibirapuera sempre teve skatista. A galera que não anda de skate está ligada. No Vale sempre teve skatista. Nos outros picos também. Pista de skate então... Aí de repente, na Paulista, que é o centro comercial de São Paulo, começa uma invasão (Raphael "Pezão", entrevista em 29 de março de 2010, grifos meus).

Sidney Arakaki, assim como "Pezão", atribui a culpa da construção de uma má imagem aos skatistas que iniciaram a prática há pouco tempo (a "molecada"), que tentam se exibir em público sem ao menos ter um nível técnico para isso:

A maioria dos novos skatistas, dos moleques que começam a andar, é para se mostrar, para exibir. Então quanto mais gente tiver passando, eles querem tentar fazer as manobras que não sabem para se exibir. O cara não tem noção de nenhuma manobra. Naquela o skate acaba espirrando, atropelando, atrapalhando todo mundo (Entrevista em 7 de dezembro de 2010, grifos meus).

Durante o trabalho de campo observei duas situações que vão ao encontro dos apontamentos dos interlocutores. A primeira delas aconteceu em um sábado à tarde. Em frente ao Banco Safra, localizado na esquina da Avenida Paulista com a Rua Augusta, alguns skatistas tentavam mandar manobras em uma borda de mármore. Entretanto, o pico situa-se próximo a uma faixa de pedestres, local pelo qual passam muitas pessoas. Em determinados momentos, os skatistas perdiam o equilíbrio e seus respectivos skates escapuliam em direção aos transeuntes. Muitos apresentavam olhares de desaprovação para a prática, tendo em vista o local onde ela era feita. A segunda situação aconteceu no mesmo lugar, porém em um domingo. Era noite, havia um intenso trânsito de pedestres e, em meio a isso, um skatista colocou um cone no centro da calçada. Seu objetivo era pulá-lo, mas a cada tentativa, ele quase se chocava com outros que passavam por aquele espaço.

Ciente das atitudes feitas por certos skatistas, as quais prejudicam os praticantes de um modo geral, a Revista Tribo Skate, em uma matéria especial sobre a Avenida Paulista, orienta os leitores a terem bom senso e respeito com o próximo:

Andar de skate na primeira via pública recapeada com cimento liso e arborizada de São Paulo é uma tarefa que exige uma dose extra de bom 
senso da nossa parte, os skatistas. Não existe a mínima condição de, por exemplo, rolar uma sessão na hora do almoço, em plena quarta-feira. Azar seu se você atravessou a cidade para andar e encontrou uma multidão na calçada. Sorria, procure outro pico, volte outro dia. Uma atitude errada de um ou outro skatista mais inconseqüente pode acabar com a diversão de todos nós. A idéia para perpetuar o skate na Avenida Paulista é simples: skate no pé e bom senso e respeito na mente ("Mug", Marcelo. Revista Tribo Skate, edição 161, 2009, grifos meus).

Os discursos anteriormente apresentados por Raphael "Pezão" e Sidney Arakaki, apontam dois tipos de skatistas que utilizam os picos para a prática do street skate: a "molecada" e os que "andam sério de skate". Enquanto os primeiros geralmente circulam em companhia de muitos skatistas, os últimos, ao contrário, preferem ir aos picos acompanhados por poucos. O objetivo é não chamar tanta a atenção para a prática nos equipamentos que ficam em espaços com regras privadas, o que facilita a produção das imagens:

Se você vê bastante gente concentrada num pico, procure outro lugar, pois vai embaçar. Aí vai você, o fotógrafo e o skatista. Daí trabalha bonitinho, só os três, rapidinho, aí ninguém enche a paciência. Com certeza, se tiver um monte de gente, todo mundo fica olhando, pois é um lugar que passa bastante gente a pé (Victor Ferrari, entrevista em 16 de abril de 2010).

Agora muita gente andando na sessão, principalmente em pico proibido, é pedir para o cara não andar. Porque demonstra uma certa forma de desorganização, de bagunça, de algazarra, que muitas vezes em uma rotina de trabalho não existe. E é difícil fotografar com muita gente, filmar e tal. Então quanto mais gente andando é pior, "queima o filme” com o segurança, porque vira uma zona, vai chamar a atenção de pessoas que não podem saber que a gente está andando ali. Quanto menos gente, melhor (Marcelo "Mug", entrevista em 6 de abril de 2011).

Outra estratégia adotada pelos skatistas para usar os picos e, conseqüente, fazer as imagens das manobras, é ir até lá no momento em que a circulação de pedestres não esteja tão intensa e, também, nos períodos em que estabelecimentos estejam fechados, como na madrugada ou durante os finais de semana. Alguns interlocutores me disseram 
até levar um gerador de energia, caso o local se encontre sem luz. A iluminação do pico facilita a sessão de skate e de fotos:

O que acontece é assim: se você quer filmar ou fotografar em algum lugar, você tem que ver. Tem pico que você pode ir fim de semana ou dia de semana à noite. Daí você tem que analisar que hora fecha o comércio ou que horas tem menos movimento de trânsito, para tentar andar no lugar. É uma forma underground de driblar a repressão (Jorge Costa, entrevista em 19 de março de 2010).

Nos picos que não abrem nos fins de semana, a gente vai no domingo. Ou então nos picos que não dá para ir de dia, então vamos de madrugada. Vem, monta o equipamento, faz a sessão, e mesmo assim sujeito a não ter a sessão (Rodrigo "Bocão", entrevista em 11 de abril de 2011).

Mesmo com essas estratégias, muitas sessões podem não acontecer. Desse modo, em cada situação os participantes se valem de táticas diferentes para o uso do pico. Subornar seguranças é uma delas:

Tem lugar que você chega e nem põe o skate no chão e chega o guardinha: "saí daqui, não pode andar". Tem lugar que eles chegam e trocam idéia sossegada. Falam: "pô, meu patrão vai brigar comigo. Por mim eu deixava vocês andar aqui, mas é meu serviço". Daí a gente entende o lado dos caras. Mas tem uns que a gente fala: "eu te pago uma pizza" (Rodrigo "Bocão", entrevista em 11 de abril de 2011).

Teve uma vez que a gente foi andar lá em Floripa e tem uma borda que é despencando. E tem seguranças no prédio. Só que aí era final de semana. Aí a gente falou: "a gente te dá dez contos para você comprar alguma coisa". E o cara: "Ah, está bom, vai lá" (Marcelo "Dohdoh", entrevista em 11 de abril de 2011).

Entretanto, a maioria dos seguranças é intransigente e não cede aos apelos. E quando a situação não é resolvida cordialmente, para solucionar de forma mais eficaz a disputa pelo espaço, muitos deles chamam a polícia. Certos interlocutores me disseram que mesmo assim não se sentem acuados. Ao contrário, quando isso acontece, calculam aproximadamente quanto tempo demora para que uma viatura chegue até o pico em que 
estão, e com base em suas previsões, aproveitam mais alguns breves minutos para finalizar a manobra, a foto e a filmagem.

Estar atento ao calendário também é algo importante para os streeteiros. Em determinadas datas do ano, principalmente em feriados, há maior facilidade para andar em picos privados que contam com forte aparato de segurança e onde a prática do skate é extremamente proibida. O fotógrafo Caetano Oliveira relata o seguinte caso:

Cada lugar que você vai é diferente para você andar. Tem lugar que você tem que chegar formalmente, pedir para andar. Outros, você já chega invadindo. É muito diferente. Tem lugar que só dá para ir de madrugada. No caso de uma capa que fiz do Vinicius Amorim, o lugar é muito difícil de andar, porque é um prédio empresarial. A gente foi na véspera do Natal, no dia 23 , às 2 da manhã. Nós fomos para fazer a foto, e o segurança devia estar no espírito natalino. Ele deixou a gente mandar mais umas manobras. Mas cada lugar é de um jeito. Tem vez que os caras chegam com arma. Cada dia é uma experiência nova (Entrevista em 7 de abril de 2011).

É válido lembrar outra situação ocorrida ao longo da pesquisa. Em alguns meses de 2010, vários skatistas tiveram diversas oportunidades consideradas únicas. A cidade de São Paulo fica pouco movimentada enquanto acontecem os jogos da copa do mundo de futebol ${ }^{268}$. Relativamente, poucos carros e pessoas circulam pelas ruas. Logo, aproveitando-se da falta de atenção de seguranças, guardas e policiais por conta da transmissão dos jogos, inúmeros streeteiros fizeram imagens em picos em cuja prática era tida, até então, como inimaginável ${ }^{269}$ :

Eu fiz [uma foto em um] corrimão com o Bruno Araújo, que fica em frente a um hospital. Só consegui fazer a foto de manhã cedo, no dia de Copa do Mundo, onde os caras não estavam nem aí para a parada. Então eu consegui fazer. E ninguém mais conseguiu fazer, porque ali tem câmera de seguranças por todos os lados (Shin Shikuma, entrevista em 12 de abril de 2011).

\footnotetext{
268 Evento futebolístico realizado na África do Sul, no ano de 2010.

269 Aproveitando-se dos jogos da copa do mundo, a marca Element Skateboards criou, em 2010, uma ação chamada "Element Impossible Spots". A idéia era premiar os skatistas que conseguissem fazer fotos, durante a realização dos jogos de futebol, nos picos mais inusitados da cidade, onde a prática do skate é tida como proibida. Mais informações em: http://elementskateboards.com.br/impossiblespots/. Acesso em 13 de maio de 2011.
} 
Por fim, uma das estratégias mais utilizadas é um simples pedido de autorização para os agentes responsáveis pelos picos onde a prática do skate, a princípio, não é permitida. Por envolver questões burocráticas, o pedido é feito com base em uma série de argumentos. O principal deles é que os envolvidos na sessão (geralmente skatista, fotógrafo e videomaker) não estão ali para se divertir, muito menos para fazer algazarra ou destruir equipamentos, mas ao contrário, por conta de um trabalho que será publicado na mídia especializada. Com efeito, câmeras e filmadoras atuam como intermediárias nas relações estabelecidas, sendo utilizadas estrategicamente pelos skatistas em suas sessões pela cidade:

Em alguns lugares, eu não costumo já chegar andando, usando. Prefiro trocar idéia, levar numa boa, mostrar que é meu trabalho, fotografando, filmando, para a pessoa que está ali querendo me tirar do local. Mostrar que faz parte do skate (André "Hiena”, entrevista em 26 de março de 2010).

[O uso de câmeras e filmadoras] é um argumento. Aí eles não vêem que a gente está ali só de brincadeira, que nem muita gente que tem impressão que skate é só brincadeira. Estou aqui fazendo meu serviço, estou dando uma idéia para você, para fazer meu serviço. E é aquela idéia, que estamos na rua fazendo foto para revista. Revista tem que viver dessas coisas. Aí você chega com material e tipo: "estamos com fotógrafo de tal revista, estamos aí fazendo uma matéria e o lugar aqui é legal para andar". Aí o pessoal meio que entende que é tipo um trabalho mesmo. É mais fácil de conversar e convencer o pessoal que não estamos de brincadeira ali (Rodrigo "Bocão", entrevista em 11 de abril de 2011).

[Com a câmera] você quebra aquela idéia de que está ali somente para se divertir. Você dá um caráter mais profissional. Isso se apresenta como uma forma de trabalho. A reação das pessoas quando você chega para zoar é uma, quando você chega para trabalhar é outra. Então uma câmera, flash, quanto maior o equipamento, mais seriedade você passa para o cara que está ali barrando sua sessão (Marcelo "Mug", entrevista em 6 de abril de 2011, grifos meus).

Às vezes, uma simples conversa com câmeras e filmadoras em mãos resolve todos os empecilhos para a realização de uma sessão. Porém isso é raro, visto que o skate, como já dito anteriormente, muitas vezes é associado ao vandalismo, por danificar 
certos espaços ${ }^{270}$. Contudo, ainda é importante ressaltar, com base nos discursos dos interlocutores, os deslocamentos simbólicos em torno dos sentidos atribuídos à prática do street skate. Várias falas apresentadas no primeiro e no segundo capítulo apontam para a valorização da "diversão" no momento em que se anda de skate. Com base no exposto agora, nota-se também outro aspecto: a dimensão do "trabalho". A produção de imagens, sobretudo em picos onde a prática é proibida, é justificada pelos skatistas aos outros citadinos por meio de discursos que valorizam não só o lado esportivo, mas principalmente o lado profissional ${ }^{271}$. Isso não deixa de ser, portanto, mais uma estratégia que se adota conforme as situações vivenciadas nas ruas.

\subsection{2 - Discursos sobre repressões e permissões}

Embora existam centenas ou milhares de picos espalhados por toda a cidade, a maioria fica em espaços cujo acesso é restrito. E por conta disso, geralmente são vigiados por pessoas para coibir qualquer ato visto como transgressor. Em boa parte dos casos, basta o skatista se aproximar de algum equipamento localizado na calçada de um prédio comercial, por exemplo, para que, logo em seguida, homens de terno venham-lhe repreender. Nessas situações, por conta das distintas lógicas atribuídas ao uso dos espaços urbanos, as relações estabelecidas nem sempre são amistosas.

Conforme apresentado, diversos tipos de estratégias são utilizados pelos streeteiros, tendo em vista o uso e a produção de imagens em picos onde a prática é proibida. Obviamente, as estratégias podem ser bem ou mal sucedidas, o que faz com que a incerteza prevaleça antes de qualquer sessão.

Seguranças, policiais e guardas municipais são apontados pelos interlocutores como um dos repressores da prática. Sessões em vários picos privados, como os da Avenida Paulista, por exemplo, são interrompidas por eles, que muitas vezes não medem esforços para enquadrar e revistar os skatistas envolvidos. Sendo assim, não é raro encontrar casos de repressão por se andar de skate em algum pico da referida avenida:

\footnotetext{
270 Para uma análise mais detida sobre este aspecto, vide "Entre a marginalização e a esportivização: elementos para uma história da juventude skatista no Brasil" (Brandão, 2008).

271 Discursos relacionados ao lado profissional do skate serão apresentados no decorrer dos próximos tópicos deste capítulo.
} 
Na Paulista, eu já tomei dois enquadros. Mas nunca aconteceu nada demais. Uma vez eu estava lá andando, o cara [o policial] enquadrou, botou na parede, pediu RG e depois falou: "não fica andando mais aqui não!”. E todo mundo voltou a andar normal. O cara passou lá depois de novo e não fez nada. Os caras fazem isso para mostrar serviço (Caio Youssef, entrevista em 15 de abril de 2010).

Eu já tomei enquadro da polícia indo para a faculdade. O cara falou: "não pode andar aqui, etc.”. Eu falei: "já saiu em Diário Oficial, essas coisas? Eu estou ligado em como funciona estas regras!". Daí ele: "não é para andar de skate aqui. Vaza!”. Eu entendi a mensagem. Mas eu já tomei uns cinco, seis enquadros na Paulista. Só porque eu estava de skate. Aí é aquela velha repressão. E lá tem dois: ou é o segurança, ou é a polícia. Tem segurança que conversa: “poxa, não pode andar aqui, beleza!”. Daí, tranqüilo. Tem cara que chega berrando. Tem cara que lá de dentro não fala nada. Só chama a polícia. Daí a polícia chega e já sobe a calçada mesmo. Vai lá no meio, enquadra todo mundo. Revista todo mundo, cada um para o seu canto (Raphael "Pezão", entrevista em 29 de março de 2010).

É importante esclarecer que seguranças, policiais e guardas municipais, na maioria das vezes, entram em ação quando o sentido atribuído à prática do skate é considerado, a partir de suas lógicas, como inapropriado para o local. Se um skatista utiliza seu skate como um meio de transporte, para se locomover pela cidade, geralmente não encontra tantos problemas, afinal, o "carrinho" está sendo usado como um meio alternativo de locomoção "que não polui o ambiente" ${ }^{272}$. Entretanto, se o skatista tentar utilizar um espaço, ainda que por breves minutos, para realizar manobras em seus equipamentos, ele corre o risco de ser repreendido. A prática na Avenida Paulista representa bem esses aspectos.

As repressões sofridas pelos streeteiros, sobretudo quando tentam realizar sessões em picos proibidos, manifestam-se de diversas formas. Elas podem ser desde uma simples bronca dada por um segurança, até a prisão de todos os envolvidos. Marcelo "Mug", com base em sua experiência de skatista e fotógrafo, distingue por meio de sua fala essas situações, resolvidas de forma tanto pacífica quanto hostil:

272 Esse pode ser considerado outro discurso estrategicamente acionado pelos streeteiros quando são repreendidos pela prática do skate. 
Repressão tem toda hora, em todos os lugares. Tem de tudo. Os grandes vilões são os seguranças. A polícia às vezes embaça, mas ela geralmente vem quando um morador ou segurança chama. Ou quando a gente está andando num banco, num lugar que tem certo perigo, que eles acham que a gente está fazendo outra coisa. Mas o grande vilão mesmo são os seguranças. Eles tesouram a sessão. Tem de tudo: o cara que chega na boa, troca idéia e explica que isso é o trabalho dele, que vai queimar o filme dele. Quando o cara chega na boa, tenta explicar, a gente tenta explicar que a gente também está trabalhando. Muitas vezes o cara acha que a gente está ali para fazer algazarra, para destruir o pico, meio anarquista. A gente sempre explica para o cara que estamos trabalhando, que ele é skatista profissional, o cara está fazendo vídeo, eu trabalho para uma revista. O grande lance é sempre tentar expor. Ele tem um trabalho que é zelar por aquele patrimônio e a gente também tem um trabalho que é usufruir daquele lugar, mas sem tentar destruir o patrimônio dele. Mas tem cara que já chega na ignorância. Tem polícia que já chega apontando a arma na cabeça. Não tem muito uma regra (Entrevista em 6 de abril de 2011).

Diversos skatistas, fotógrafos e videomakers interlocutores desta pesquisa já passaram por momentos de tensão ao tentarem andar de skate e fazer imagens em picos privados. Relatos é o que não faltam quando o assunto é "sessões que não deram certo". Caio Yousseff contou-me uma situação vivenciada anos atrás. A tentativa de uma sessão em um lugar aparentemente tranqüilo (o estacionamento de um supermercado) culminou em várias confusões entre skatistas e policiais:

Uma vez também eu tomei um enquadro... Esse enquadro foi tenso. Estava eu mais uns seis caras. A gente foi andar no Santo Amaro, naquele Supermercado Dia. Lá no fundo tem uma borda com cantoneira perfeita, o chão é lisinho, tem corrimão lá. O pico é perfeito. Só que daí tem três prédios residenciais. E era domingo. E neste Supermercado Dia, em nenhum dia tem grade e o chão é sempre liso. E de domingo ele não abre. Então a gente sempre andou nestes dias. Uma vez a gente estava lá. Foi bem na época dos ataques do PCC ${ }^{273}$. Colaram três viaturas "à milhão" [rapidamente]. Já entraram no meio do supermercado botando arma na cabeça de todo mundo: "vai todo mundo para a parede". Eu estava de costas e nem vi. Quando eu vi, o policial já estava apontando arma para mim: "vai

273 Em 2006 houve em São Paulo, assim como em muitas outras cidades, uma série de atos de violência contra forças de seguranças e alvos civis. Os constantes ataques adquiriram repercussão a partir do isolamento de líderes do Primeiro Comando da Capital (PCC) em presídios de segurança máxima. 
moleque, vai para a parede!". Aí foram todos para a parede. Levamos o maior enquadro. E rolou a maior discussão. Um amigo meu disse que um policial ameaçou ele de morte. O policial pediu o documento do carro e a mãe do cara tinha sido roubada na mesma semana, a bolsa da mulher. Então o documento estava lá e perdeu ele. O policial não acreditou na cena e [disse]: "olha moleque, se você estiver mentindo para mim, eu boto você de costas neste banco e meto o pipoco. Ninguém vai nem sentir sua falta!". Foi sinistro. Este enquadro foi o mais "cabreiro" que levei em minha vida (...). A gente foi lá falar com os policiais e rolou a maior discussão (...). Foi sem noção. Foi por conta dos moradores do prédio, por causa do barulho do skate. Vai ver que um deles tinha "trampado" a semana inteira e queria dormir depois de ver o jogo do time. (Entrevista em 15 de abril de 2010).

\section{O fotógrafo Caetano Oliveira também vivenciou situações parecidas. A primeira} aconteceu na cidade de Guarulhos, quando ele, um videomaker e um skatista tentaram fazer uma sessão em uma área cujo acesso é proibido:

Teve uma vez que a gente estava num ponto de ônibus em Guarulhos, perto do aeroporto. Acho que é área militar e não pode andar de skate. Eu estava filmando com o "Gema" e o Everton "Tutu". A gente estava fazendo uma seqüencia. De repente chegou um cara de moto, com a arma apontando para a gente, gritando: "sai daqui, sai daqui, filho da puta! Não pode andar aqui! Está louco?”. Ele estava totalmente fora de si, apontando a arma para a nossa cara. A gente: “calma, não precisa chegar assim. Você não tem educação?". Com a discussão o cara foi ficando nervoso, e a gente foi embora, antes de acontecer qualquer besteira (Entrevista em 7 de abril de 2011).

Mas esse não foi o único momento constrangedor pelo qual Caetano Oliveira e seus amigos passaram. Em 2010, diversos skatistas viajaram para o Chile, em busca de novos picos que possibilitassem a captura de imagens inéditas para a mídia especializada brasileira. Tudo corria bem na sessão, até que um segurança apareceu:

No Chile também, estávamos andando na parte do Centro. Tinha um banco e tinha uma escada. A gente pôs o banco na escada, para andar em frente a um prédio comercial. Estava eu, o Marcelo Gouvêa, o "Johnny" Melhado, o Rocco (do Chile), uma galera de lá também. Estávamos andando. Eu tinha acabado de montar o equipamento. Chegou o segurança e falou que não podia andar, porque estava estragando. Nós falamos: “está bom, vamos 
embora". Só que nisso ele ficou transtornado e parecia que queria brigar com a gente. Ficou louco. Teve uma hora que ele pegou meu tripé com flash. Acho que ele não estava no direito de fazer isso. Então eu puxei a mão dele com força e tirei. Daí ele foi e pegou outro tripé, que estava sem o flash. E falou: "eu não vou devolver até a polícia chegar". Só que ele estava com um negócio que era meu. Nisso, o Marcelo Gouvêa foi por trás e ergueu ele, e o cara ficou morrendo de medo. O Danilo Diehl arrancou o tripé e ficou aquela tensão. Chegou mais segurança. Daí tinha o Carlos, lá do Chile, que falou: "eu vou ficar aqui para não ter problema, para a gente continuar andando por aqui, para não 'queimar o filme' do skate”. Ele ficou lá e nós fomos rápidos para o estacionamento. Por pouco não ia sair briga com a gente em outro país (Caetano Oliveira, entrevista em 7 de abril de 2011).

Casos de repressão são sempre acionados pelos interlocutores no sentido de demonstrar as dificuldades encontradas para o uso de certos picos. Conseguir burlar todas as adversidades e andar de skate em espaços proibidos é algo valorizado entre os streeteiros. Embora reconheçam que as manobras eventualmente danifiquem alguns equipamentos, eles sempre deixam claro em seus discursos que "skate não é crime" e que os repressores da prática, muitas vezes, estão errados por conta da forma truculenta com que abordam os skatistas.

Contudo, as estratégias utilizadas pelos skatistas nem sempre culminam em repressões parecidas com as apresentadas. Com efeito, muitas sessões também são bem sucedidas. Nos "rolês” pela cidade, é possível encontrar pessoas que compreendem a prática e que, inclusive, ajudam os skatistas na produção de suas imagens. O próprio Caetano Oliveira relata uma situação que o deixou surpreendido:

Uma vez a gente estava na Zona Leste. Estava com o Glauber Marques. Até saiu nessa última [revista] Tribo, um smith de front. Daí a gente foi num mercado e bem na entrada tinha um corrimão. A gente achou que não podia andar. Eu fui falar com a gerente, e os caras: "você nunca vai conseguir!". Falei com a gerente e ela pediu aos seguranças para fazerem a escolta da gente. Ela fechou a entrada do mercado, só para a gente andar. Durante pouco tempo, mas deu certo para fazer a foto. Os clientes do mercado iam entrar e ela: "Não, vocês não estão vendo eles filmando? É do outro lado, na outra escada!". A escadinha era no canto do mercado. Com isso, eles tinham que dar maior volta. Os senhores de idade tinha que dar maior volta, porque a gente estava filmando, fotografando (Entrevista em 7 de abril de 2011). 
O fotógrafo Marcelo "Mug” também já experimentou situações inusitadas em algumas sessões de skate. A primeira delas aconteceu na Argentina. Um policial curiosamente o aconselhou a pular as grades de uma faculdade para andar de skate:

A gente estava na Argentina. A Argentina é muito louca. Os seguranças, que aqui no Brasil têm de truculento e mal educado, lá na Argentina os caras têm de educação. Teve um dia que a gente estava em frente a um prédio. $\mathrm{O}$ segurança estava conversando com a gente, falando que não podia. Ele explicou, falando que tinha uma câmera que foi instalada no ano passado, e que agora não pode mais deixar andar. Antes ele deixava andar. Nesse momento a polícia passou na rua. Ele viu que a gente estava insistindo e chamou a polícia. A polícia veio, trocou idéia com a gente. O policial me chamou de canto e falou: "Esquece. Nesse lugar vocês não vão andar". Só que ele começou a me passar uma lista de picos que a gente podia andar. E falou até uma coisa engraçada: "aquela faculdade ali, que tem grade e tudo, vocês podem pular e andar. Ali é um lugar público e eu garanto que vocês vão poder andar tranqüilos”. Era proibido, mas ele autorizava a gente (Entrevista em 6 de abril de 2011).

A outra situação vivenciada por "Mug” aconteceu na Avenida Paulista:

A gente estava na Avenida Paulista. Estávamos eu e o Pablo, que é o fotógrafo da [revista] Cemporcento, fotografando um skatista gringo. A polícia parou. Era domingo de manhã, mas já tinha um certo movimento. A gente começou a sessão bem cedinho, para justamente não atrapalhar a galera. Daí começou a ficar mais tarde. O skatista demorou para acertar a manobra e começou a passar bastante pedestre e tal. Alguém reclamou que a gente estava atrapalhando e chamou a polícia. Alguma senhora, não sei. Ninguém veio falar com a gente, mas a gente sabe que alguém chamou a polícia. O policial parou do nosso lado. Ficou 1 minuto e meio com a gente fotografando, o skatista andando e tal. Ele veio e se apresentou com toda a educação e perguntou para qual revista a gente trabalhava. Na verdade a gente deu sorte porque o policial já tinha sido skatista um tempo atrás. Então ele sabia, ele conhecia qual era a proposta de tudo aquilo. Então ele sabia que a gente não estava andando ali porque a gente queria, porque a gente queria fazer zoeira. Ele pegou nossos nomes, pediu para gente manter, de certa forma... Esperar as pessoas passarem, andar de skate só nos momentos certos, deixou a gente continuar fotografando até a hora da gente terminar o 
nosso trabalho. Mas isso é estupidamente raro (Entrevista em 6 de abril de 2011).

Neste tópico, portanto, foram apresentados diversos discursos acerca de momentos em que a prática do skate é reprimida ou permitida. A partir do instante em que o skatista, acompanhado de um fotógrafo e de um videomaker, se aventura a tentar burlar regras de segurança para fazer imagens em espaços de acessibilidade restrita, está sujeito a vivenciar situações que não podem ser previstas. Já em outros picos localizados em espaços públicos, a possibilidade de uma sessão ser mal sucedida por conta de repressão é bem menor. Entretanto, as preocupações são outras, conforme se verá a seguir.

\section{2 - Sessões em picos públicos}

Durante os primeiros meses de 2010, Sandro Sobral (skatista profissional e juiz do Circuito Sampa Skate) dedicou-se intensamente à produção de sua entrevista para a Revista Tribo Skate. Ter esse espaço em uma publicação não é nada fácil. Com poucas edições especializadas no mercado e com muitos praticantes que pretendem aparecer, qualquer oportunidade de visibilidade torna-se demasiadamente disputada. Logo, quando surge uma chance como essa, cabe ao skatista aproveitá-la da melhor forma, fazendo imagens que demonstrem seu nível técnico na prática do skate.

A entrevista de Sandro Sobral seria composta por fotos feitas em diferentes picos públicos da cidade de São Paulo, a maioria deles localizados no Centro, local mais freqüentado por esse skatista. Apesar da escolha de picos considerados tradicionais (como os encontrados no Vale do Anhangabaú, Praça da República e viaduto da Consolação), o skatista pretendia fazer somente manobras inéditas. Isso certamente valorizaria a entrevista, demonstrando um diferencial desse profissional perante os demais.

Durante o mês de março, tive a oportunidade de acompanhar algumas sessões. Ciente da produção da entrevista, entrei em contato com Marcelo "Mug", fotógrafo responsável por fazer as imagens de Sandro Sobral. Por meio dele, recebi o convite para presenciar a realização das fotos.

Na tarde de uma terça-feira, encontro "Mug" na redação da Revista Tribo Skate, localizada em Perdizes. Dali, partiríamos para a Praça Roosevelt, no Centro, onde 
encontraríamos Sandro Sobral. Porém, assim que chegamos ao ponto de ônibus, começou a chover intensamente, o que nos fez desistir da ida. Voltamos para a revista; o skatista, porém, parecia estar mesmo disposto a fazer as fotos, tanto é que ligou para "Mug" e o convenceu de que a chuva não lhes traria problemas. Embora não fosse coberto, o local em que a sessão seria feita não estava com o chão tão molhado. Além disso, Sobral disse que estava preparando boas condições para que ele pudesse andar de skate, secando o pico com um rodo que havia levado.

Pegamos o ônibus e não demoramos muito tempo para chegar à Praça Roosevelt. Esse local foi um dos principais pontos de encontro para os streeteiros durante o final da década de 1980. Entretanto, anos depois, com a reforma do Vale do Anhangabaú, a praça perdeu boa parte de sua importância. Mesmo assim, ela ainda continua sendo palco para sessões, as quais são feitas de forma cada vez mais inusitada e criativa. No espaço correspondente à praça, há vários lugares skatáveis, muitos deles construídos, reformados ou adaptados pelos próprios skatistas. Lá, existe uma diversidade de tipos de bordas, guias, inclinações, escadas, canteiros e muros, ressignificados por meio do olhar skatista. Um dos grandes atrativos do local é a pouca repreensão encontrada. Acostumados com a presença constante de crianças, jovens e adultos, com seus respectivos skates, policiais e guardas municipais raramente repreendem tal prática nesse espaço público.

No momento em que chegamos, a praça estava totalmente deserta. Rapidamente encontramos Sandro Sobral, que segurava um rodo com suas mãos cheias de calos, trabalhando a todo vapor para que o pico ficasse pronto para a sessão. Ele fazia questão de deixar claro que todo esforço é útil para que as fotos sejam feitas. Alexandre "Nicolau" e Renan Hassan, ambos da Zona Leste, também estavam presentes. Entretanto, não andariam de skate, pois teriam que filmar e incentivar o amigo a acertar a pretendida manobra.

O obstáculo em que Sandro Sobral mandaria sua manobra seria o wallride, isto é, uma parede inclinada de concreto. Para facilitar a prática nesse pico, os próprios skatistas que andam na praça tiveram que cimentar aquilo que chamam de "entrada", ou seja, o espaço entre o chão e a parede, tornando-o contínuo.

Alexandre "Nicolau" se posicionou em cima de uma mureta, segurando a filmadora. Já Marcelo "Mug” optou por ficar paralelo ao pico, porém um pouco distante, de onde faria várias fotos em seqüência de todos os movimentos da manobra do skatista. Como o dia estava nublado, era preciso agilidade na sessão devido à chuva 
iminente. Com o videomaker e o fotógrafo a postos, Sandro Sobral começou a tentar um caballerial flip no pico escolhido por ele. Segundo o skatista, acertar essa manobra não é nada fácil. Tanto que ninguém nunca havia conseguido isso naquele local. Por ser inédita, caso a conseguisse, a foto publicada na revista renderia bons comentários.

Para atingir seu objetivo, Sandro Sobral tomava uma considerável distância do obstáculo. Parava, respirava, concentrava e pegava impulso naquela direção, demonstrando a necessidade de um planejamento para acertar a manobra. Ficou claro que o skatista já tinha em mente tudo o que pretendia fazer, calculando a velocidade que deveria chegar ao obstáculo, a força com que chutaria o skate, os movimentos que faria com o corpo e, também, a forma com que cairia, caso errasse a manobra.

O caballerial flip não era uma manobra nova para o skatista. Por possuir a sua base, cabia a ele superar o obstáculo. Naquele instante a única coisa que importava era a eficácia em torno dessa única manobra, a qual era tentada sucessivas vezes. O fotógrafo, de longe, estava atento a todos os movimentos, na expectativa de realizar a sequiência de fotos. "Nicolau", por sua vez, com a filmadora em mãos registrava pacientemente todos os instantes. O tempo passava e Sobral não conseguia seu objetivo. Era possível ver estampado em seu rosto uma fisionomia de preocupação e impaciência. Após respirar fundo, ele novamente ia ao obstáculo, e para seu desespero, mais um erro. Por não corresponder às expectativas, o skatista demonstrava muita raiva. Para descontar a fúria momentânea, pegava seu skate e o jogava no chão. Em seguida, dizia alguns xingamentos em voz alta, alternando com palavras de incentivo a si próprio.

Os outros presentes também tentavam motivar Sandro Sobral. Renan Hassan disse que até pagaria um chá mate após a sessão, caso o skatista acertasse a manobra. O local aos poucos escurecia. Como "Mug" não havia levado os flashes, fez um ultimato: "só mais cinco minutos de sessão!". A partir daí o skatista começou a se dedicar ainda mais. Nesse "tudo ou nada" ${ }^{274}$, ele corria o risco de se machucar, afinal a iluminação do local não favorecia. Por fim, já estava de noite e não tinha mais jeito. A manobra não foi concluída.

Muito irritado, Sobral lamentou não ter conseguido o seu objetivo. O que mais o angustiava era o fato de que dias antes ele conseguira acertar duas vezes a mesma manobra pretendida, inclusive, uma delas durante uma sessão de filmagens. Mas para que a manobra saísse em sua entrevista na revista, ele teria que acertá-la novamente,

274 Utilizo essa expressão com base no discurso nativo. 
agora sob a presença do fotógrafo. "Mug" o tranqüilizou, dizendo que poderia voltar ali quantas vezes ele quisesse para tentar novamente. Como se não bastasse isso, ainda se dispôs a marcar outras sessões pelos picos do Centro. Como Sobral não pretendia desistir daquilo que havia proposto, marcou uma nova sessão de fotos na Praça Roosevelt, já na manhã do próximo dia.

No outro dia de manhã, quando o risco de chuva seria menor, fomos para a sessão. Por volta das 11 horas chego à Praça Roosevelt. Sandro Sobral e Marcelo "Mug” já estavam lá, acompanhados de outros dois amigos que observavam o que estava sendo feito. O skatista aparentava estar bem mais tranqüilo que no dia anterior. Mas só aparentava. Sobral me disse que estava muito nervoso, se sentindo pressionado para acertar a tão esperada manobra. E faltava pouco para isso: depois de chutar o skate, bastava colocar o pé da frente em cima do shape e manter o equilíbrio. Entretanto, por mais que parecesse fácil, o obstáculo, obviamente, dificultava a ação. A cada nova tentativa, o skatista parecia não acreditar em seus erros. "Mug" me disse que este era o terceiro dia de sessão de fotos na Praça Roosevelt. Nesse momento, cabe ao fotógrafo ser paciente e entender a ansiedade do skatista. Por isso, ele tentava transparecer tranqüilidade, não o deixando intimidado com sua presença.

A bateria da câmera estava no final. Logo, restavam apenas poucas tentativas para que a manobra fosse feita. Antes mesmo de a bateria acabar, o skatista profissional disse a "Mug" que não agüentava mais. Com seus 36 anos de idade - 30 andando de skate Sobral estava muito cansado, com o corpo dolorido. Para aliviar a tensão, jogou o skate no chão, fez novamente alguns xingamentos e disse que desistiria. Naquele dia não dava mais. Observando a situação, "Mug" foi até ele dizer palavras de incentivo. O skatista contou ao fotógrafo que tinha se preparado mentalmente na noite anterior. A manobra que estava tentando não era o problema para ele, tanto que já a tinha acertado antes. Porém, uma sessão de fotos impõe certa pressão, deixando-o ansioso e, por vezes, impaciente, o que resulta na ineficácia da técnica empregada no momento. "Mug" questionou Sobral se o psicológico influencia na hora de andar de skate, e ele respondeu com convicção que:

Com certeza, principalmente quando você menospreza uma manobra, isso não existe. Falei "vamos lá, já acertei duas vezes seguidas, é chegar de prima e acertar". De prima não chegou mais, nunca mais voltou. Sou 
brasileiro, não desisto nunca, mas não rolou de novo (Entrevista com Sandro

Sobral, Revista Tribo Skate, edição 183, 2011, p.74).

Resolvemos ir embora. Sobral foi encontrar alguns amigos no Vale do Anhangabaú, porém não andaria mais de skate naquele dia, pois estava evidentemente frustrado. De todo modo, "Mug" se prontificou a fazer novas sessões no mesmo pico, pois, em sua concepção, "uma hora o skatista teria que acertar a manobra".

Depois de algum tempo reencontrei o fotógrafo, que me disse ter realizado um total de oito sessões com Sobral. Infelizmente, o skatista não conseguiu acertar a manobra, contudo, nem por isso, segundo "Mug", a entrevista deixou a desejar. Muitas outras fotos foram feitas, sendo que em diversas delas o skatista apresentou um nível técnico invejável para quem é streeteiro há tantos anos. No mês de janeiro de 2011, após quase um ano de captação de imagens, a entrevista foi publicada com destaque nas páginas da Revista Tribo Skate e elogiada por muitos leitores.

\section{3 - Imagens em picos privados e públicos}

A prática do street skate pode ser feita em múltiplos espaços, os quais se tornam, partindo da concepção de De Certeau (2009, 184), lugares praticados. Nesse sentido, assim como “(...) a rua geometricamente definida por um urbanismo é transformada em espaço pelos pedestres" $(2009,184)$, um equipamento urbano pode ser transformado em pico pelos streeteiros ${ }^{275}$. Isso os leva, com efeito, a atualizar, deslocar e inventar um conjunto de possibilidades de usos dos espaços através de suas sessões pela cidade ${ }^{276}$.

Conforme demonstrado etnograficamente, cada um dos espaços utilizados resguarda certas particularidades que orientam a forma como as sessões são realizadas. Antes de utilizar qualquer tipo de pico, portanto, o streeteiro deve estar preparado para todos os imprevistos que podem ocorrer, mas sempre tendo como meta o alcance de pelo menos três objetivos básicos, a saber: conseguir que a sessão seja bem sucedida,

\footnotetext{
275 Deste modo, portanto, "existem tantos espaços quantas experiências espaciais distintas" (MerleauPonty, 1976 apud De Certeau, 2009, 185). De Certeau $(2009,45)$ mostra ainda que certos usos comuns de determinados bens e espaços são perpassados por modos próprios de utilização por parte dos citadinos, os quais se dão entre as representações que as instituições buscam impor (o que o autor define como estratégias) e as maneiras através dos quais estes controlam suas próprias vidas (o que pode ser definido como táticas).

276 Para De Certeau $(2009,184)$ o espaço pode ser definido como "um cruzamento de móveis", o qual está sujeito a conflitos e mobilidades, ao invés de uma estabilidade. A ausência dessa estabilidade e a predominância de conflitos, com efeito, é o que se tenta evidenciar etnograficamente por meio da observação da prática do street skate em certos espaços da cidade de São Paulo.
} 
isto é, que não se encontre nenhum tipo de repressão; acertar a manobra escolhida, e registrar imagens (em fotos e/ou vídeos) do momento em que a mesma for feita.

Para que os objetivos apresentados sejam conquistados, deve-se ter em mente que andar de skate num pico privado não é a mesma coisa que andar de skate num pico público. O skatista Sandro Sobral está acostumado a praticar nesses dois tipos de picos, e com base em sua vasta experiência, distingue-os da seguinte forma:

Tem dois jeitos de você trabalhar, que eu acho: tem um lugar que ninguém nunca andou, onde você pode mandar uma manobra mais fácil. Nunca ninguém andou. Então você pode apresentar o pico, depois quem quiser, vai lá e evolua o pico. E tem o pico que todo mundo anda, então você tem que mandar manobra melhor que todo mundo (Entrevista em 31 de março de 2010, grifos meus).

Tal fala aponta para alguns aspectos que permitem compreender o uso e a produção de imagens em cada tipo de pico. Os lugares em "que ninguém nunca andou" podem ser vistos como espaços cujo acesso normalmente é proibido e que, na maioria das vezes, são vigiados por seguranças os quais impedem a prática do skate. Devido às dificuldades para sua utilização, os picos privados se tornam cobiçados no universo do street skate. Afinal, conforme ouvi certa vez de um skatista, "andar de skate em lugares proibidos é sempre mais emocionante". Por esse motivo, as fotos feitas nesses locais são mais valorizadas. Prova disso é que o skatista que consegue burlar as regras de segurança para mandar sua manobra em um pico que nenhum outro praticante tenha conseguido andar, passa a ser respeitado por seu grande feito ${ }^{277}$. Os fotógrafos Caetano Oliveira e Marcelo "Mug" concordam que:

\footnotetext{
277 Outras diversas práticas encontradas nas grandes cidades, nem todas de cunho esportivo, também possuem dinâmicas pautadas pelo enfrentamento do risco como forma de obtenção de prestígio e visibilidade. Angelina Peralva (2000), por exemplo, ao analisar a prática do surfe ferroviário entre jovens moradores de áreas periféricas das cidades de São Paulo e Rio de Janeiro, notou que os praticantes exercitam e relativizam o controle do risco, o qual é expresso por meio de suas condutas em cima dos tetos dos trens. A partir de experiências compartilhadas em companhia de outros, os jovens adeptos do surfe ferroviário buscam “(...) a afirmação da vida como prazer ligado à superação do medo" (Peralva, 2000, 169). Já Le Breton (2009), ao investigar a dimensão do risco em diversos tipos de práticas esportivas, também apontava que nas "condutas perigosas em (...) bicicleta ou mobilete, em skate ou carrinho de rolimã etc., pode-se perceber muitas vezes a influência do grupo de pares nos desafios a que se lança os jovens, ou na estima de si mesmo que tratam de conseguir", e portanto, o "jovem tende a superar suas apreensões para afirmar sua identidade ao olhos dos outros” (Le Breton, 2009, 46).
} 
O cara vai ver a revista, vai ver a foto de um lugar onde ele sempre sonhou em andar, mas que nunca conseguiu por causa dos seguranças, por causa da polícia. Ele vai ver que você foi lá e fez um trabalho e vai dizer: "nossa, isso é demais! Queria muito andar aqui". Isso vai ter um valor absurdo para o skatista (Caetano Oliveira, entrevista em 7 de abril de 2011, grifos meus).

As pessoas sabem que certos lugares são impossíveis de andar. Então você chega com uma foto com uma manobra difícil [ela é valorizada]. Não só a execução da manobra foi difícil, mas todo o contexto para chegar até ali foi complicado. A gente sabe que o skatista não teve tempo para tentar muitas vezes [a manobra], que o fotógrafo não teve tempo para testar a luz para chegar e fazer [a foto], [teve que] montar o equipamento rápido. Tem que ir de madrugada, tem que ir de domingo, e provavelmente outra pessoa será difícil ir lá e fazer outra coisa. Então essa é a conjuntura que leva [a foto ser valorizada]. É legal ir ao Vale, na Praça da Sé, aonde todo mundo vai, é liberado andar e tal. Mas quando eu estou procurando fazer um trabalho para a revista, eu gosto de ir a lugares diferentes, inéditos, e isso implica muitas vezes que o lugar vai ter segurança, que é proibido, que ninguém nunca andou lá, que o gap é alto, que o corrimão é alto. Então para mim, quanto mais desafiador, quanto mais inédito e proibido, [melhor] (Marcelo "Mug", entrevista em 6 de abril de 2011).

Shin Shikuma, editor de fotografia da Revista Tribo Skate, tece uma interessante comparação. Em sua visão, o fato de um skatista conseguir andar de skate em um pico privado se assemelha ao "pixador que consegue pixar a parte mais alta de um prédio. Existe essa competição no skate, de conseguir fotos em lugares proibidos" ${ }^{278}$. Esses discursos atestam que os streeteiros procuram os mais inusitados equipamentos urbanos para andar de skate não por conta da falta de espaços "próprios" para a prática, como as pistas, mas ao contrário, em virtude das experiências compartilhadas entre eles que valorizam o skate praticado nas ruas, ou para ser mais específico, em espaços com acesso limitado, principalmente naqueles que não permitem que manobras sejam feitas

\footnotetext{
278 Entrevista em 12 de abril de 2011. A comparação feita por Shin Shikuma se aproxima também das análises feitas por Pereira (2005). Ao analisar o universo da pixação na cidade de São Paulo, o pesquisador notou que: "quanto mais um pixador se arrisca, mais ele ganha reconhecimento dos outros. Surge, assim, uma competição para ver quem pixa mais alto em determinados prédios da cidade. Quando um deles consegue pixar mais alto que o outro em algum edifício, este se sente desafiado e tentará pixar mais acima ainda. Esta competição para ver quem deixa sua marca na parte mais elevada de um prédio é chamada por eles de 'quebrar o pixo'. Embora, não seja uma ofensa direta como o atropelo, quebrar o pixo de alguém pode gerar certas desavenças, mas também maior popularidade” (Pereira, 2005, 37).
} 
em seus equipamentos. Desafiar as proibições é, portanto, algo que perpassa os discursos e as práticas no universo da modalidade street skate.

Uma das justificativas para a intensa produção de imagens em picos privados é que, por meio delas, o skatista pode provar aos outros que conseguiu conquistar e usar espaços tidos pelos demais como inapropriados para a prática do skate:

É uma forma de provar, tipo, que conseguiu fazer isto por mérito do skatista mesmo. Ele correu atrás e conseguiu o seu espaço, conseguiu fazer o que ele queria, do jeito que ele quis" (Rodrigo Bocão, entrevista em 11 de abril de 2011).

A dificuldade da manobra feita em um pico privado muitas vezes não é o primordial. O importante no instante da sessão é mais o uso do espaço e menos o nível técnico do skatista ${ }^{279}$. Tanto é que comumente são publicadas em revistas fotos de manobras tidas como "fáceis". Um bom exemplo é uma foto estampada na capa da Revista Tribo Skate, na edição de maio de 2008. A imagem mostra o skatista Guilherme Okamoto realizando uma manobra, chamada crail air, em uma escultura da artista Tomie Ohtake exposta na área do aeroporto da cidade de Guarulhos. Do ponto de vista técnico, de acordo com a perspectiva dos próprios interlocutores, a manobra feita pelo skatista é considerada simples. No entanto, a utilização do pico é considerada extremamente difícil. Marcelo "Mug”, que realizou a foto, relatou-me que teve de bolar uma série de estratégias para conseguir tal feito. Com muita cautela e em questão de breves minutos, a imagem e a manobra tiveram de ser feitas. Apesar do risco de serem presos, o fotógrafo e o skatista conseguiram utilizar um pico que nenhuma outra pessoa ligada ao skate havia conseguido. Por isso, a foto foi contemplada com a capa da revista.

O uso de picos privados, portanto, sempre é feito rapidamente. O tempo em que se fica em um espaço onde a prática do skate não é permitida é bastante limitado. Daí a importância em planejar antecipadamente tudo o que será feito durante a sessão. Chegase ao local com metas pré-definidas: o skatista mentaliza qual manobra mandará, o fotógrafo e o videomaker analisam qual o melhor ângulo em que podem se posicionar, e todos os envolvidos ainda deixam combinado qual a tática utilizada caso sejam

279 Contudo, é importante esclarecer que uma imagem se torna ainda mais valorizada se uma manobra considerada "difícil” for acertada em um espaço cuja prática do skate é proibida. 
repreendidos por seguranças, guardas ou policiais. Rodrigo "Bocão" compartilha dessa perspectiva:

\footnotetext{
Não é um lugar que você vai ficar brincando ali. [É] meio que um objetivo: "vou fazer isso em tal lugar". Vamos lá, chega, monta o equipamento, acerta e beleza. Se tiver repressão, tenta voltar outro dia, mas sempre com o objetivo de acertar a manobra (Entrevista em 11 de abril de 2011).
}

Já os picos em "que todo mundo anda", para utilizar uma expressão de Sandro Sobral, normalmente são espaços públicos (como Vale do Anhangabaú, Parque do Ibirapuera, Praça Roosevelt, etc.), onde praticantes de diversas partes da cidade se encontram ${ }^{280}$. Além de propiciar a constituição de formas de sociabilidade mais densas e duradouras, a repressão relacionada à prática do skate nesses locais é quase nula. Por conta disso é possível encontrar a presença de skatistas em quase todos os dias e horários. Nesse sentido, ter a chance de mandar manobras em equipamentos urbanos localizados em espaços públicos, por exemplo, nem sempre constitui um desafio a ser superado.

Enquanto as imagens feitas em picos privados são valorizadas por conta do espaço utilizado, em picos públicos, isso se dá por conta da manobra feita. O caso de Sandro Sobral, citado no tópico anterior, ilustra essa comparação. A Praça Roosevelt é um espaço público onde a prática do skate é permitida; logo, qualquer skatista consegue facilmente fazer imagens nos picos encontrados por lá. Como forma de distinção, para que imagens feitas nesse espaço sejam valorizadas, as manobras devem ser inéditas e mais difíceis que as outras que já foram realizadas ${ }^{281}$. As falas abaixo tornam clara essa idéia:

Geralmente o skatista já vai com essa idéia: "se fulano mandou um 50-50 aqui, eu tenho que mandar um grind, que é uma manobra que é mais difícil que a outra". Rola muito, no mundo do skate de: "ah, ele já mandou essa manobra. Você vai mandar uma que é mais fácil?”. Não rola uma visibilidade boa, tanto para as marcas quanto para os outros skatistas. Então ele tenta sempre se superar e mandar uma coisa mais difícil. Até para o fotógrafo, não vale a pena ir fazer uma foto, uma vez que rolou uma

\footnotetext{
${ }^{280}$ Não obstante, pode haver alguns picos situados em espaços com regras privadas em que "todo mundo anda". Porém, isso é mais raro.

${ }^{281}$ Vale salientar que essa disputa de manobras também pode acontecer em picos privados, embora seja mais perceptível em picos públicos.
} 
manobra super difícil, e o cara querer ir lá fazer uma mediana (Caetano Oliveira, entrevista em 7 de abril de 2011).

Que nem você vai ao pico e: "fulano já deu isso aí, mano! Já deram um 5050 e eu vou dar um rockslide?" Aí o pessoal fala: "não, vou dar um flip 5050”. Aí sempre querem por manobras no pico. Isso é engraçado. Às vezes aparece um pico novo e vai cada vez mais manobra. Vem alguém e faz uma manobra. Aí vem outro maluco e faz uma manobra ainda mais foda. Aí você fala: “caralho!” (Rodrigo “Bocão”, entrevista em 11 de abril de 2011).

Essa lógica faz com que impere, mesmo que indiretamente, uma disputa por conta da melhor manobra acertada em um pico público. Em virtude disso, muitos fotógrafos e videomakers evitam fazer imagens de manobras consideradas fáceis em lugares como o Vale do Anhangabaú. Por ser em São Paulo, há tantos anos, um espaço central para a prática do street skate, inúmeras manobras já foram feitas por lá, o que tira o ineditismo de muitas imagens captadas. A exceção acontece, porém, quando o skatista consegue fazer algo totalmente inusitado, explorando o pico de uma maneira criativa:

$\mathrm{Na}$ real, nem gosto de filmar no Vale. [Mas] ali meio que tem coisa para fazer ainda. É um lugar muito grande. Tem muito jeito de você andar ali diferente. E o pessoal sempre acaba achando um jeito de andar. Eles passam vela numa borda que nem tinha. E o pessoal anda. É mais no improviso mesmo (Rodrigo “Bocão”, entrevista em 11 de abril de 2011).

Marcelo "Mug" acredita que para um skatista ter a foto de uma manobra feita no Vale do Anhangabaú publicada, ele precisa "tirar leite de pedra":

A foto tem que mostrar alguma coisa diferente do que já foi feito. Se você pegar um lugar, como o Vale do Anhangabaú, que está na cena há dez, quinze anos já, já saiu muita coisa, tanto em vídeo quanto em foto... Então se você publicar numa revista um ângulo normal de uma manobra que todo mundo já deu no Vale, não vai ter impacto nenhum. Para o cara ter uma foto publicada no Vale do Anhangabaú, numa revista ou numa mídia especializada, ele tem que partir de alguma coisa diferente, tem que procurar partir de lugares que ninguém nunca usou no Vale, ou fazer uma manobra bem difícil. O cara tem que tirar "leite de pedra" e o fotógrafo tem que conseguir um ângulo diferente, ou uma luz diferente, porque já foi muito 
explorado e ninguém quer ver coisa repetida. Então o grande lance é fazer alguma coisa inédita (Entrevista em 6 de abril de 2011).

Dessa forma, os discursos em torno dos diferentes usos dos espaços urbanos revelam alguns sentidos atribuídos à prática do street skate. A produção de imagens nas ruas, por sua vez, tem sido focada nos últimos anos por muitos streeteiros, fazendo, inclusive, com que campeonatos realizados em pistas percam parte de sua importância no universo pesquisado.

\section{4 - Correr campeonatos ou produzir imagens?}

Desde o começo do trabalho de campo, ainda no Circuito Sampa Skate, percebi que os skatistas destinam um interesse especial às imagens que deles são feitas. Entretanto, algumas dessas imagens possuem mais valor que outras. Por mais que participem de uma série de competições, o que é mais valorizado nesse meio, conforme demonstrado no capítulo anterior, é andar de skate nas ruas. Logo, as imagens produzidas nos diversos picos encontrados são muito mais respeitadas que aquelas feitas em campeonatos e em pistas.

De todo modo, imagens feitas em pistas figuravam em muitas matérias publicadas pela mídia especializada até poucos anos atrás ${ }^{282}$. As lógicas em torno da modalidade street skate favoreciam aos skatistas "campeonateiros"; portanto, saber andar numa pista era uma condição essencial ${ }^{283}$. Nesse contexto, o respeito perante os demais praticantes podia ser conquistado, em boa parte, com base em rankings de circuitos. Tanto é que um dos critérios para profissionalização era, inclusive, o bom desempenho em competições amadoras regulamentadas pela Confederação Brasileira de Skate (CBSk). Dessa maneira, skatistas amadores e profissionais de todas as partes do Brasil ficavam bem mais atentos - se comparado à atualmente - ao calendário anual de competições, pois, por meio das classificações conquistadas, podiam ganhar não só

\footnotetext{
282 Ao longo da década de 1990, por exemplo, era mais comum encontrar revistas com imagens de skatistas andando de skate em pistas da modalidade street skate.

${ }^{283}$ Isso não quer dizer que os skatistas deixem de participar dos campeonatos. Esses tipos de eventos são importantes, embora atualmente existam outras formas de buscar o prestígio e o profissionalismo no street skate que não seja somente por meio de competições.
} 
status e boas premiações, como também, conseguir patrocinadores e obter espaço na mídia especializada ${ }^{284}$.

Segundo alguns interlocutores, competições com formato de disputa parecido com o do Circuito Sampa Skate, no qual cada competidor possui apenas 1 minuto para realizar suas manobras na pista, tinham mais visibilidade que hoje em dia ${ }^{285}$. Esse critério era considerado uma forma mais objetiva de avaliação do nível técnico de cada skatista. Os eventos realizados, como os inúmeros circuitos que aconteciam anualmente, reuniam diversos competidores que se dedicavam intensamente à prática do skate nas $\operatorname{pistas}^{286}$.

Nas competições tradicionais de street skate, conforme visto no primeiro capítulo, cada competidor, avaliado por um corpo de juízes, possui um tempo cronometrado para fazer a apresentação de seu nível técnico na pista. Porém, essa limitação o impede de mostrar, de fato, boa parte daquilo que sabe fazer em cima do "carrinho". Não obstante, ele ainda pode errar todas as manobras em mente, passando uma impressão ao público de que, do ponto de vista técnico, não é um bom skatista. Nesse sentido, de acordo com os interlocutores da pesquisa, os julgamentos das competições (como o Circuito Sampa Skate) nem sempre revelam quem são os skatistas de melhor nível técnico, já que o que está em jogo é o acerto das melhores manobras num tempo determinado ${ }^{287}$.

Sandro Sobral possui uma vasta experiência atuando como juiz de campeonatos, mas, mesmo assim, não concorda com o formato de avaliação adotado:

Skate é um negócio que dá prazer andar. É andar de skate. Não é para ser julgado. Se você gosta de um tipo de manobra e eu não gosto, você vai julgar de uma forma diferente. É subjetivo. Se todo mundo acertar, como que julga? E se todo mundo errar? Eu prefiro hoje, na minha atual situação, deixar de correr campeonato e me dedicar a filmar (Entrevista em 31 de março de 2010).

\footnotetext{
${ }^{284}$ Nessa dinâmica, ganhar campeonatos propiciava ao skatista conquistar espaço na mídia especializada. Prova disso é que os melhores colocados em rankings, sobretudo de campeonatos profissionais da década de 1990, constantemente figuravam em muitas matérias produzidas.

285 O referido formato foi difundido, sobretudo, na década de 1990 e no começo dos anos 2000. Atualmente muitos campeonatos ainda utilizam esse formato, embora existam outras opções.

${ }^{286}$ Entre os inúmeros circuitos que aconteciam é válido destacar a importância do Circuito QIX Amador e do Circuito Drop Dead de Skate Amador. Esses circuitos foram responsáveis por revelar muitos skatistas que se tornaram profissionais respeitados no universo do street skate não só brasileiro, como mundial.

${ }^{287}$ Para mais detalhes, vide Capítulo I.
} 
A fala do skatista chama a atenção para um fato importante: como definir, dentro do tempo estipulado da competição, quais são as melhores manobras? Como juiz Sobral reconhece que a avaliação das manobras de cada competidor não é feita por si só, pois só tem sentido se for julgada em relação às outras. Portanto, se para uns $x$ é a melhor manobra, para outros, ao contrário, y é a melhor. No contexto de um campeonato, que pressupõe uma definição objetiva de quem é o vencedor, isso pode gerar certas confusões. Por isso a avaliação feita pelo corpo de juízes nem sempre é compatível com aquela feita pelos espectadores que estão na arquibancada. De todo modo, conforme apresentado anteriormente, a indefinição de quem é o "melhor skatista" é tida como algo positivo, pois dilui uma suposta rivalidade entre os competidores. Nesse jogo relacional, em cada situação específica pode surgir o "melhor", nem sempre definido por um consenso coletivo, mas mediante a preferência individuais.

A popularização da Internet e o fácil acesso aos equipamentos digitais, como câmeras e filmadoras, trouxe novas alternativas à dinâmica construída em torno da visibilidade que pode ser adquirida por um skatista no universo do street skate. Apesar de buscarem boas colocações em campeonatos, muitos deles priorizam a captação de imagens nas ruas, as quais possivelmente serão publicadas em vídeos e revistas. Por meio do discurso de Rodrigo "Bocão" é possível compreender esse aspecto:

Antigamente não tinha tanto recurso. Se você quisesse ter uma filmadora, ninguém tinha. Eram poucas pessoas. Hoje em dia, a molecada tem filmadora, pode filmar e postar suas manobras na Internet. Você está fazendo seu serviço, mostrando seu serviço, mas de um outro jeito. No campeonato você vai mostrar ali, vai se dar bem ali. Mas não é toda vez que você vai se dar bem em 1 minuto. Tem dia que "pô, estou zoado, não consegui andar", e não é legal. Na rua você está ali, você tem seu tempo para fazer, você tem sua obrigação, mas não é uma obrigação que você tem que estar ali correndo, de que tem que fazer àquela hora. Você pode fazer devagar, concentrado. Você fala: "hoje não estou legal para andar...”. Você sai para descansar e é aquela coisa que você vai filmando. Antigamente o pessoal não tinha tanto acesso a filmadora, fotografia, era um recurso meio que para poucos. Hoje em dia tem mais recursos. Antigamente você ia fazer uma foto, e era bem rapidinho. Era três filmes para você voltar uma manobra. Hoje em dia tem as digitais. Têm bem mais fotógrafos hoje em dia, vários bons saindo de todo lugar. Isso ajuda bastante. Então não precisa estar ali no campeonato. Hoje em dia tem a Internet e esses vídeos que você pode estar ali aparecendo (Entrevista em 17 de março de 2010). 
Ao comparar as distintas importâncias atribuídas à participação em campeonatos e à produção de imagens, Rodrigo "Bocão" se refere, sobretudo, às experiências que cada uma das ações condiciona ao skatista.

Poucos skatistas encontravam espaços na mídia especializada na época em que as fotos eram feitas com câmeras que usavam filmes, e os vídeos com filmadoras que usavam VHS. Afinal, além das dificuldades técnicas, não havia tantos profissionais capacitados para captar imagens de qualidade, passíveis de serem publicadas. Atualmente, ao contrário, a facilidade em fazer fotos e vídeos propicia aos skatistas obterem prestígio e buscarem o profissionalismo de diversas maneiras, conforme comprovam os relatos a seguir:

Hoje em dia se torna difícil para o cara que é focado em campeonatos. Se não tem campeonatos, o cara não aparece. Aí vai forçar ele sempre a fazer fotos, filmar. Hoje em dia tem muita gente filmando para os vídeos. Aí procura estar fazendo umas partes para os vídeos, filmando umas manobras, e revista também. Mas mesmo assim é difícil, essa parte de divulgação. O evento é ali, na hora, tem ali os seus minutos, só que acabou o evento, todo mundo esquece quem ganhou, quem mandou a manobra. E uma revista ou um vídeo não. A molecada vai estar sempre assistindo. Às vezes alguns eventos têm a première. Às vezes rola até de algumas pessoas mostrarem uns vídeos antigos. Os skatistas que têm essa consciência vão procurar divulgar essa parte (André "Hiena”, entrevista em 26 de março de 2010).

$\mathrm{Na}$ real o campeonato nunca foi tão importante para mim assim. $O$ campeonato não mostra qual é o teu valor de verdade. Qual é o teu "rolê". Skate é um esporte de dia. Tem dia que você vai num pico e manda todas. Tem dia que você vai ao mesmo pico e não consegue dar nada. É impressionante. Mas campeonato é às vezes uma coisa injusta. Porque o cara mais "cabreiro", vai que no dia ele torce o pé. Ou cola lá, manda umas manobras e fica em segundo. Daí o cara que nem anda tanto, faz um "rolê" que nem é "cabreiro" e ganha. Vídeo você trabalha mais. É um trabalho. Você mostra o seu skate como ele é. Mostra seu skate na rua. Os picos que você gosta de andar. As coisas que você gosta de fazer em cima do skate. Pista não proporciona muito isto. A rua mostra seu skate de verdade. (Caio Youseff, entrevista em 15 de abril de 2010, grifos meus). 
Pensando como skatista, se eu tivesse uma marca de skate, eu daria valor para o cara que está na rua, saindo na revista. Mas eu não tiro o valor de quem participa de campeonato. Só que campeonato é uma parte bem pequena do skate. Em minha opinião, o campeonato é uma parte do skate que é legal de ter, só que não é só aquilo. Se eu tivesse uma marca e o cara chegasse para mim e dissesse "eu sou campeão de todas as etapas!", isso para mim não interessa muito porque o cara mostrar o que sabe fazer em 1 minuto... Mas o cara que é de uma marca de skate, que vive o skate até hoje, ele sabe que é a rua é bem mais importante, sair na mídia de revista. Mas, sem tirar o mérito do campeonato, porque campeonato tem seu mérito também. Eu acredito que a mídia é bem melhor (Alexandre "Nicolau", entrevista em 26 de março de 2010, grifos meus).

O skate nas ruas não se submete às formatações que tentam regulamentar sua prática, tais como as encontradas em campeonatos ${ }^{288}$. Com isso os skatistas dispõem de mais liberdade e tempo para acertar as manobras e produzir as imagens. São eles que determinam o que e onde fazer ${ }^{289}$. Caso não consigam fazer uma sessão bem sucedida num dia, geralmente tem-se a oportunidade de fazê-la posteriormente. O skatista pode ser seu próprio agente, muitas vezes capaz de determinar o ritmo da prática conforme os objetivos estabelecidos. Sandro Sobral, por exemplo, demorou aproximadamente um ano para produzir cinco fotos que foram publicadas em sua entrevista na Revista Tribo Skate ${ }^{290}$.

Uma das motivações em aparecer em publicações especializadas é a possibilidade de conquistar patrocinadores. Caso um skatista tenha, por exemplo, a foto de sua manobra publicada, poderá anexá-la ao seu portfólio pessoal e apresentá-la a possíveis empresários interessados em investir em sua carreira ${ }^{291}$. Se isso acontecer, a prática do skate adquire um outro significado. Além de diversão, ela também passa a ser um compromisso profissional:

\footnotetext{
288 A Confederação Brasileira de Skate (CBSk) é a agência que tenta regulamentar o formato das competições realizadas em pistas. Para informações sobre regulamentos e outras normas, vide http://www.cbsk.com.br/pags/regulamento.htm. Acesso em 12 de maio de 2011.

289 A partir desse contexto é válido o apontamento feito por Le Breton $(2009,90)$. Ao pesquisar práticas esportivas consideradas "radicais", como o skate, o autor postula que "em oposição declarada às atividades físicas baseadas no treinamento, na disciplina, na competição, elas são individuais e valorizam o prazer (o fun), as emoções, as sensações, a estética dos movimentos". Essa consideração nos permite compreender, em certa medida, a recusa de muitos skatistas em se auto-intitularem atletas e também, a razão por não darem atenção especial ao lado competitivo de muitos eventos.

290 Todavia, muitas marcas que patrocinam determinados skatistas podem agenciar as suas práticas, impondo-lhes uma série de compromissos que devem ser cumpridos.

${ }^{291}$ Vide, por exemplo, o modelo de portfólio do skatista Alexandre "Nicolau”, no Anexo B.
} 
Para as marcas é um retorno até maior você estar em evidência em uma revista, em evidência em vídeos de skate. Porque o público que acompanha o skate vai ver mais revistas, não vai ver resultados de campeonato. Uma revista você vai ver, vai ficar com ela folheando, e depois de um ano: "pô, aquele maluco apareceu em tal foto, em tal lugar" (...). Tem que estar sempre aparecendo, conseguir filmar umas manobras para sair nos vídeos que estão aparecendo por aí, fazer o máximo de fotos possíveis para que um dia até tenha uma entrevista em uma revista, alguma coisa. Tendo seus espaços aos poucos (Rodrigo “Bocão”, entrevista em 17 de março de 2010).

Por isso, conforme visto no início deste capítulo, quando os skatista fazem sessões visando à produção de imagens, muitos se referem à prática do skate como um "trabalho" e não como uma "diversão" ${ }^{292}$.

O fato de os skatistas priorizarem a captação de imagens, não exclui, todavia, a participação em campeonatos. Desse modo, ter espaço na mídia especializada é algo valorizado, mas nem por isso os skatistas deixam de participar de competições realizadas em pistas ${ }^{293}$ :

$\mathrm{Na}$ verdade a cabeça da galera no Brasil era totalmente voltada para campeonatos. E hoje em dia, como o skate não é só isso, então tem o lado do campeonato e o lado de você sair para filmar, fazer foto, para fazer uma demo. Tudo isto serve como uma divulgação, para divulgar a marca que te patrocina. Divulga seu nome. Coloca em prática seu skate, tudo o que você aprendeu, o que você está aprendendo. Você aprende coisas novas no meio de tudo isto aí (Tiago Garcia, entrevista em 13 de abril de 2010).

Eu acho o mais legal no campeonato é que com certeza vai reunir todo mundo. Por isso que é legal estar todo mundo participando de um ou outro. Com certeza o que dá mais prestígio para a pessoa são os trabalhos nas ruas: fotos em revistas e partes em vídeos. Só que campeonato é um jeito de você encontrar todo mundo que você não encontra faz tempo, de você mostrar suas manobras para os caras que te conhecem, de ver as manobras dos caras,

\footnotetext{
${ }^{292}$ Caso o skatista tenha um patrocinador, é por meio de fotos e vídeos que ele poderá divulgá-lo. O último tópico deste capítulo apresentará situações que contemplarão etnograficamente esse aspecto.

${ }^{293}$ Bastos (2006), em sua dissertação de mestrado sobre a trajetória de skatistas profissionais, reconhece que os praticantes não dependem unicamente das competições nem do capital corporal, pois a própria configuração do universo em que estão inseridos "se movimenta no sentido de atribuir maior valor aos filmes e revistas que competições, passando estes dois instrumentos a receber maior relevância" (2006, 87).
} 
de comemorar todo mundo junto. Igual eu falei, ninguém contra ninguém ali. É legal porque são 40 pessoas, 50 pessoas, que você nunca mais viu e você está vendo ali de novo e todo mundo torcendo para o outro ganhar. Para os skatistas teria 50 primeiros lugares. Na verdade não tem uma competição em si (Victor Ferrari, entrevista em 15 de abril de 2010).

A atual configuração da modalidade street skate favorece a produção de imagens para a mídia especializada, embora os campeonatos organizados com formatos tradicionais também reúnam muitos skatistas motivados por diversos tipos interesses, conforme apresentado no Capítulo I. Logo, há uma continuidade entre produzir imagens e participar de competições, da mesma forma que há continuidade entre a prática do skate nas ruas e nas pistas. E para dar conta disso, muitas marcas especializadas tentam articular uma coisa a outra: fazem competições nos próprios picos, ou então, realizam competições virtuais por meio de imagens captadas, sobretudo, nas ruas.

\subsection{1 - Competição nas ruas}

A DC Shoes, marca especializada em tênis para a prática do skate, promove desde 2008 uma competição completamente diferente das que já foram feitas para a modalidade street skate no Brasil. Intitulado DC King of São Paulo, o evento reúne a cada edição aproximadamente cinqüenta skatistas amadores de todas as partes do país, previamente selecionados pela organização para uma competição que envolve quantias em dinheiro ${ }^{294}$.

Ao contrário da maioria dos campeonatos que acontecem em pistas, o DC King of São Paulo é realizado nas ruas, ou, para ser mais preciso, em picos públicos. Essa iniciativa pode ser considerada rara, tendo em vista as dificuldades encontradas por muitos organizadores de eventos para conseguir, perante o poder público, a autorização para o uso de certos espaços da cidade para a prática do skate. O evento em questão só foi bem sucedido por conta da atuação de alguns agentes ligados à secretaria de esporte do município que conseguiram mediar as relações entre os skatistas e a prefeitura. Tiago

\footnotetext{
294 A escolha dos participantes é feita pelos organizadores do evento com base em critérios decididos pela marca patrocinadora. De modo geral, os skatistas selecionados são amadores de diversas partes do país, que se destacaram por conta de seus respectivos níveis técnicos e pela visibilidade que conquistaram no street skate em virtude de suas imagens captadas.
} 
Lobo, coordenador de esportes radicais, é apontado como o principal responsável por essa mediação 295 .

A cada edição são escolhidos dois espaços públicos da cidade de São Paulo como palco para a competição, realizada durante um final de semana. Em 2008, foram selecionados a Praça do Morumbi e o Vale do Anhangabaú, enquanto em 2009, a Blue Square ${ }^{296}$ e a Praça Roosevelt, e, em 2011, a Praça Dina ${ }^{297}$ e a Prafinha ${ }^{298}$. A intenção dos organizadores do DC King of São Paulo é aproveitar parte dos picos desses locais, onde os skatistas comumente mandam suas manobras, para fazer a disputa. Escadarias, corrimãos e bordas foram os obstáculos mais utilizados nas edições realizadas até o presente momento. Mas, além disso, também são feitas mais algumas intervenções, a fim de deixar os picos em boas condições para a prática do skate. Na Praça do Morumbi, por exemplo, acrescentou-se uma cantoneira de ferro a uma borda, enquanto na Blue Square o corrimão anexo a uma escada foi reformado. Portanto, além do apresentado, outra intenção do evento é a reforma de alguns picos públicos considerados tradicionais em São Paulo, iniciativa que beneficia os skatistas de modo mais amplo.

Com base nisso, a Revista CemporcentoSkate faz a seguinte ressalva:

Desde o começo (...), o DC King of São Paulo causa uma grande expectativa em todos os envolvidos. O formato do evento, que utiliza espaços públicos e que, portanto, são utilizados diariamente por qualquer skatista, aproxima o evento da realidade diária de cada um. Todo mundo conhece bem as dificuldades que os competidores vão enfrentar e, enquanto comemoram as manobras dos que competem, ficam imaginando como será a sessão do dia seguinte, quando aqueles obstáculos estarão à disposição (Prieto, Douglas. A disputa da coroa. Revista CemporcentoSkate, edição 156, 2011).

A competição possui um formato diferenciado, o que faz com que os participantes se sintam bem à vontade. Com base no número de inscritos são criadas baterias de dez

\footnotetext{
295 Tiago Lobo pode ser considerado o agente ligado ao poder público cujas idéias mais se aproximam daquelas compartilhadas no universo street skate paulistano. Enquanto Tiago Lobo busca apoio perante o poder público para a realização de competições em picos públicos, outros agentes, ao contrário, tentam a proibição da prática nas ruas da cidade de São Paulo.

296 Blue Square é o nome dado pelos skatistas à Praça Abelardo Rocas, situada em Perdizes.

297 Praça Dina é uma atribuição dada pelos skatistas a um espaço público localizado na Rua Luís Correia de Melo, na região de Santo Amaro.

298 Prafinha é uma pequena quadra pública, localizada no Real Parque. O nome do espaço faz referência ao skatista profissional Rafael "Finha", que teve a iniciativa de construir obstáculos de skate e os colocar em uma quadra para os skatistas.
} 
competidores que andam juntamente no mesmo pico durante o tempo de 20 minutos. Enquanto isso, são observados por três juízes, que atribuem suas notas secretamente. Portanto, a avaliação do nível técnico de cada um, em vez de individualmente, é feita de forma coletiva. Esse formato, chamado de jam session, aos poucos substitui o tradicional formato já apresentado, em que cada competidor possui apenas 1 minuto para fazer sua volta na pista.

No formato jam session, os skatistas acumulam pontos conforme a dificuldade e o número de manobras apresentadas nos obstáculos selecionados. Os competidores que obtêm as melhores médias com base nas notas atribuídas pelos juízes avançam de fase até o momento em que sobram somente quatro finalistas. A competição testa a técnica de cada skatista em diferentes picos que são encontrados nas ruas. Enquanto as pistas possuem obstáculos construídos especialmente para a prática do skate, nas ruas, os obstáculos, ao contrário, muitas vezes são improvisados. Logo, a competição se torna instigante por conta dessas dificuldades impostas. O skatista que conseguir superá-las e, consequientemente, obtiver a maior pontuação na junção dos pontos dos dois dias de competição, é o grande vencedor, ou melhor, o "rei de São Paulo" (king of São Paulo). Durante a premiação ele recebe, simbolicamente, uma coroa personalizada, além de um cheque com a quantia em dinheiro ${ }^{299}$.

O DC King of São Paulo possui visibilidade no street skate brasileiro por conta de sua proposta de tentar realizar competições nas ruas, o que comumente não é feito. Em virtude disso, a mídia especializada destina um considerável espaço em suas publicações para enfocar esse evento, considerado um dos mais aguardados do ano pelos skatistas amadores ${ }^{300}$.

Saber andar de skate nas ruas é algo valorizado no universo pesquisado; logo, ganhar o evento em questão possibilita prestígio ao skatista. Felipe Nery foi o vencedor da edição do ano 2011. Sua vitória lhe rendeu uma entrevista na Revista CemporcentoSkate, além de inúmeros outros benefícios que foram aproveitados após a realização da competição ${ }^{301}$.

Com a realização do DC King of São Paulo, em ao menos um final de semana do ano a prática do street skate é permitida pelo poder público em certos equipamentos da

\footnotetext{
299 O campeão da edição de 2011 faturou a quantia de $\mathrm{R} \$ 4$ mil.

300 As duas maiores revistas especializadas (CemporcentoSkate e Tribo Skate) fizeram a cobertura de todas as edições do DC King of São Paulo. Ademais, em uma de suas edições, a Revista Tribo Skate encartou um DVD com a cobertura em vídeo da competição, realizada no ano de 2009.

301 A vitória de Felipe Nery, bem como a sua entrevista, possibilitou-lhe conquistar patrocinadores.
} 
cidade. Embora sejam utilizados pelos streeteiros mesmo sem autorização, essa permissão pode ser vista como um pequeno ato concreto, representando, ainda que momentaneamente, uma conquista legítima de espaços urbanos não planejados para a prática do skate.

\subsection{2 - Competição virtual}

Devido ao crescimento expressivo do número de usuários da Internet, muitas marcas ligadas ao universo do skate passaram a investir em novos tipos de ações que, além de menos custosas, abrangem um público mais amplo. Isso se reflete na forma com que muitas competições vêm sendo feitas, as quais não precisam mais acontecer em espaços definidos de antemão, como em pistas, ganhando um caráter virtual, o que propicia a participação de skatistas de qualquer parte do país.

Com efeito, competições virtuais têm sido cada vez mais constantes entre os skatistas. As recentes ações da Qix, outra marca especializada em tênis de skate, podem ser consideradas os maiores exemplos de mudança nas formas de competições até então vigentes no street skate brasileiro. No decorrer de vários anos sucessivos, essa marca promoveu campeonatos em sua pista de skate, localizada na cidade de Novo Hamburgo - RS. Em virtude da importância dos eventos realizados, muitos skatistas viajavam até lá para participar da competição, que ocorria ao longo de um final de semana do ano. Em 2010, a marca resolveu inovar, sem, contudo, deixar de promover algo que fosse considerado inusitado. Para isso, em vez de fazer apenas um único campeonato, ela se propôs a realizar uma competição de vídeos postados pelos próprios skatistas na Internet. Essa ação traria mais visibilidade para a marca, reduziria os custos gastos com a logística do evento que antes acontecia em sua pista, e também, estimularia a participação de um número ilimitado de skatistas residentes em diversos Estados.

Ao fazer uma comparação entre campeonatos realizados em pistas e campeonatos virtuais, Marcelo "Mug” salienta que:

O campeonato [tinha] uma repercussão de um mês. Tinha o campeonato, aí saía na revista e tal. Agora esse campeonato de vídeos aí é o ano inteiro. E sai a matéria na revista conseqüentemente. E toda semana tem vídeo novo para a gente ver. É muito mais duradouro. Gera mais interação, desperta mais atenção, atrai gente de todos os cantos do Brasil. O cara não precisa viajar mais para ir até um campeonato correr. Ele pode ficar na cidade dele, 
fazendo o vídeo e mandar para você, que você vai conhecer o "Joãozinho de Carapicuíba" e o "Manezinho do Mato Grosso do Sul" (Entrevista em 6 de abril de 2011).

Competição realizada em pistas limita a participação de muitos skatistas, já que nem todos têm condições de arcar com os custos de deslocamento até as mesmas. Além disso, a visibilidade do evento se dá, sobretudo, no mês de sua realização. Já com a competição virtual, skatistas amadores de qualquer região possuem a chance de participar e de se destacar no universo do street skate. Para tanto, basta ter uma filmadora e contar com a ajuda de um videomaker. Ademais, a divulgação da ação da marca feita por meio da Internet pode ser considerada muito mais vantajosa, pois a interação virtual estabelecida com os internautas, através dos vídeos vistos online, ocorre ao longo de todo o ano.

Para participar da competição virtual promovida pela tal marca de tênis, os skatistas deveriam produzir e postar no Youtube ${ }^{302}$ um vídeo de no mínimo 1 e no máximo 2 minutos de duração, apresentando suas manobras nos picos por eles escolhidos. Uma comissão interna da marca faria a seleção das melhores publicações, as quais iriam para julgamento popular através de seu site ${ }^{303}$. A seleção feita levaria em conta os seguintes critérios: dificuldade da manobra, criatividade, estilo, perfeição na conclusão das manobras, escolha das manobras, edição e qualidade da imagem ${ }^{304}$. Portanto, o sucesso de um vídeo dependeria não só do praticante, como também do videomaker, cuja missão seria a de captar e editar as imagens.

A competição aconteceu ao longo do ano 2010 e foi dividida em três fases: eliminatória, semifinal e final. Durante vários meses o site da marca de tênis recebeu inúmeros vídeos de skatistas. E conforme comprovado, em quase todos eles a prática do skate é feita em picos encontrados nas ruas, tanto privados quanto públicos. Ao avaliar a iniciativa, o fotógrafo Caetano Oliveira salienta que:

Tem gente que consegue andar só em campeonatos e não anda muito na rua. E vive de campeonato. Teve esse caso da Qix, de fazer o melhor vídeo. [Com isso] o skatista vai atrás de viajar, conhecer novos lugares para andar de skate e conhecer pessoas que trabalham com vídeo para poderem mostrar a manobra de uma forma diferente. Eu acho que daqui para frente terá

\footnotetext{
302 Youtube é um site que hospeda vídeos postados na Internet. Informações em www.youtube.com.br.

303 Informações em www.qix.com.br

${ }^{304}$ Disponível em http://www.qix.com.br/regulamento/. Acesso em 12 de maio de 2011.
} 
sempre muito isso, não terá muito campeonato (Entrevista em 7 de abril de 2011).

No começo de 2011, o resultado foi divulgado. Depois do julgamento feito pelos internautas e pela comissão interna ligada à marca, decidiu-se que o vencedor foi o skatista Alber Leandro, de Brasília - DF. Logo após a entrega do prêmio, o vencedor ainda teria que cumprir uma outra ação prevista pelos promotores da competição: ir de Novo Hamburgo - RS até a sua cidade com o carro que havia ganhado, e durante o retorno, em companhia de um fotógrafo e um videomaker, fazer várias imagens para serem publicadas em uma edição da Revista Tribo Skate ${ }^{305}$.

\section{5 - Skatistas, fotógrafos e videomakers}

Ao longo desta pesquisa foi impossível deixar de notar a atuação de dois profissionais cada vez mais requisitados no universo do street skate. Trata-se dos fotógrafos e dos videomakers, responsáveis pela captação de imagens não só das manobras, como também, das experiências compartilhadas pelos skatistas na cidade.

O baixo custo para a compra e a manutenção de equipamentos digitais fez com que se proliferasse o número desses profissionais da mídia especializada, fato que tornou essas profissões muito competitivas. Com efeito, a opção em se tornar fotógrafo ou videomaker especializado em captar imagens de skate não se dá por acaso. $\mathrm{Na}$ maioria das vezes, conforme relatos, a pessoa começa a andar de skate, porém, em um dado momento, ao notar que as suas chances em seguir carreira como praticante são cada vez mais escassas, percebe que pode optar por um processo alternativo: em vez de se tornar skatista profissional, torna-se profissional do skate. Portanto, muitos skatistas almejam continuar ligados ao universo do street skate ao longo de suas vidas, seja somente praticando, seja trabalhando com atividades que, de uma forma ou de outra, relacionam-se à prática ${ }^{306}$. Para usar uma expressão nativa, a intenção é "trabalhar com aquilo que dá prazer" 307.

\footnotetext{
305 Publicado na Revista Tribo Skate, edição 186, março de 2011.

306 Há também casos de praticantes que são tanto skatistas profissionais quanto profissionais do skate. O fotógrafo e skatista profissional Otavio Neto, integrante do staff da Revista Tribo Skate, é um dos exemplos.

307 Essa é uma expressão comumente utilizada pelos skatistas com referência à articulação entre as dimensões da "diversão" e do "trabalho". Diversas práticas feitas sobretudo por jovens, não só esportivas, também possuem uma variedade de significados. É o caso da música, tal como estudada por Hikiji (2006), em sua análise sobre o Projeto Guri na cidade de São Paulo. Segundo a autora, os sentidos
} 
Marcelo "Mug" conta que:

Eu sempre soube que meu nível de skate nunca faria com que eu me tornasse um skatista profissional. Eu sempre vou andar de skate, mas eu sei que talento eu não tenho, ainda mais hoje em dia que os caras "comem" talento do skate quando nascem. Então eu sempre quis ser um profissional do skate, eu sempre quis trabalhar com skate, mas eu não tinha como fazer isso andando de skate (Entrevista em 6 de abril de 2011).

Embora não seja uma condição determinante, para se tornar fotógrafo ou videomaker é importante praticar ou ter praticado skate. É preciso conhecer não só as performances e os movimentos feitos com o corpo para a realização de manobras, mas também ter aquilo que muitos chamam de olhar skatista para os espaços urbanos. Por meio desses aspectos, o profissional possivelmente estará apto a conseguir imagens dentro do padrão aceito como legítimo pela mídia especializada, conforme será discutido adiante.

Se a produção de imagens da prática do skate é algo cada vez mais almejado, fotógrafos e videomakers se tornam respeitados por conta de suas respectivas funções. $\mathrm{O}$ fato de conhecer ou se relacionar com alguns deles, principalmente com os que fazem parte do staff da mídia especializada, aumenta as chances de o skatista ter seu espaço em uma publicação, seja ela impressa, em vídeo ou virtual. Desse modo, os profissionais do skate acreditam que são responsáveis por contribuir para a carreira de futuros skatistas profissionais:

A gente está aqui para mostrar como é o cotidiano do skate no país, na região, e a gente está formando estrelas, na real. A gente chega e o menino lá de 10, 11 anos [e diz]: "ah, eu quero pular uma escada". "Vamos lá, vamos lá”. Chega lá ele pula uma escada. Aí vai, a foto sai na revista, ele ganha patrocínio e começa a ganhar dinheiro. Vai ao campeonato, ganha o campeonato, começa a ter uma carreira e a viver disso. A gente forma profissionais, pessoas que vão viver do skate. E a gente está ali, no que está acontecendo de verdade, e a gente tem que mostrar isso aí para o mundo, o que está rolando (Caetano Oliveira, entrevista em 7 de abril de 2011).

atribuídos ao fazer musical não são afirmados com a mesma intenção e intensidade, e podem ser “(...) ora um quebra-galho, um passatempo, ora 'tudo' na vida de alguém” (2006, 65). Nesse caso, assim como o skate, "a música é uma atividade que permite o trânsito entre os universos do lazer e do trabalho, por vezes misturando-os" $(2006,68)$. 
A fala do fotógrafo deixa claro que, caso um skatista queira seguir carreira como praticante profissional, ele necessita produzir imagens, afinal, por meio delas tem-se mais uma importante alternativa para demonstrar os seus "trabalhos", o que lhes possibilita buscar patrocínios ou atender às exigências dos patrocinadores. Essa é, portanto, uma das determinações do mercado, fazendo com que o skatista busque incessantemente espaços em publicações especializadas. Por conta disso, fotógrafos e videomakers relatam ser muitas vezes bajulados por skatistas que se relacionam com eles somente por conta de interesses pessoais. Caetano Oliveira conta que passou a ser visto de outro modo, a partir do momento em que começou a fazer parte da equipe de fotógrafos da Revista Tribo Skate:

\footnotetext{
Você está aqui trabalhando na revista, o interesse do skatista é muito maior. Tem cara que, quando eu estava aprendendo a fotografar skate, há uns seis anos atrás, ele não fazia fotos comigo, e agora me liga, pede para ir viajar, qualquer coisa, para fazer uma foto. Só que não é só comigo. É com todos os fotógrafos. Porque é importante para o skatista ter o fotógrafo. (...) Têm vários fotógrafos de skate que não fazem mais fotos para revista, que estão fora do mercado, e ficam no esquecimento. Várias histórias de fotógrafos, que saíram de revista, e ninguém nem olha mais para eles. O cara era badalado, estava ali na revista, e agora está no esquecimento (Entrevista em 7 de abril de 2011).
}

Nessa dinâmica relacional, muitos fotógrafos também optam por selecionar, com base em seus próprios interesses, quais skatistas serão fotografados. De um ponto de vista prático, fotografar os que são patrocinados é mais vantajoso. Caso a foto seja considerada de boa qualidade, o fotógrafo terá a oportunidade de vendê-la para a marca que patrocina o skatista, para que se utilize a imagem em anúncios. Embora isso seja recorrente, nem todos admitem fazer fotos só de skatistas patrocinados. Segundo eles, é preciso ter certo equilíbrio na escolha, dando chances àqueles que também não possuem vínculos com qualquer marca. Somente dessa forma talentos são revelados. Além do fato de o skatista ter patrocínio ou não, Marcelo Mug acredita que outros fatores também são preponderantes nessa escolha:

Ser patrocinado, para mim, pouco importa. O que eu não gosto é de ir a lugares onde o cara não vai conseguir fazer aquilo, que ele não tem a 
capacidade, que ele está botando metas que ele dificilmente vai conseguir. Não gosto de ir a lugares sabendo que o cara está querendo dar um passo maior que a perna dele. O cara quer descer um corrimão gigante só para tentar sair numa capa de revista, mas ele não consegue descer um corrimão médio. Então ele está querendo, a qualquer custo, aparecer sem ter noção do perigo para ele mesmo. Esse é o tipo de sessão que eu não gosto. Ele pode ter patrocínio de todas as marcas. Se ele quiser fazer um "bagulho" que é perigoso, que ele não tem condições, acho que é um tipo de sessão que ele pode procurar outro fotógrafo para fazer. Agora se o cara não tem patrocínio nenhum, e eu sei que ele anda para "caralho", e ele está a fim de fazer as coisas porque ele gosta, e até mesmo porque ele precisa aparecer, que ele está a fim de fazer, e também porque é um desafio pessoal... "Eu quero descer o corrimão porque eu passo todo dia em frente ao 'bagulho', vou dar um nosegrind". É a melhor sessão. Quando você vê que o cara está com medo, é um desafio para o cara, sem patrocino ou não, isso pouco importa, e o cara vai lá para se superar e dar mais um passo na evolução dele e conseqüentemente na do skate (Entrevista em 6 de abril de 2011).

Lidar com desafios, medos e imprevistos é algo recorrente em qualquer sessão realizada. Nunca se sabe se o skatista conseguirá acertar sua manobra e se o pico em que se pretende andar terá o uso permitido. Mas para vários profissionais do skate, é sempre gratificante quando todas as adversidades são superadas e a prática do skate, bem como as imagens, é feita com sucesso. Em virtude disso, com base em suas experiências profissionais, fotógrafos e videomakers também procuram fazer escolhas levando em conta quais skatistas podem render mais ou menos numa sessão ${ }^{308}$.

A produção de imagens organiza parte da conduta de muitos streeteiros. Se há o risco de se machucar ao mandar uma manobra num dado pico, é melhor que esse risco seja corrido em companhia de fotógrafos ou videomakers. Nesse sentido, de nada adianta ter acertado sozinho uma manobra, sem ter feito sua imagem, afinal, sem isso fica difícil provar o feito. Desse modo, os praticantes não só revelam suas melhores técnicas diante de câmeras e filmadoras, como também superam seus próprios medos. David Le Breton $(2009,120)$ já aventara que em práticas, como o skate, “esse jogo com

\footnotetext{
308 Os skatistas que rendem mais, segundo vários fotógrafos, são aqueles que conseguem acertar uma
} variedade de manobras consideradas difíceis de forma rápida, sem tentar tantas vezes. 
a gravidade, com o risco, suscita o desejo de 'aparecer', a preocupação em 'fazer-se ver $^{\text {, }}{ }^{309}$, de evoluir com graça, encadeando manobras difíceis".

A presença dos profissionais da mídia especializada é considerada um estimulante para que os skatistas consigam acertar suas tão esperadas manobras:

Eu acho que quando vê a câmera posicionada ali, a pessoa faz de tudo para conseguir o que ela quer. Se não tem ali uma câmera, talvez ela não vá se arriscar tanto. (...) Tem os dois lados: por um lado é a carreira do cara, é o trabalho dele. Tudo que ele faz tem que ser registrado. Por outro lado, ele deixa de fazer uma coisa por lazer (Caetano Oliveira, entrevista em 7 de abril de 2011).

Rodrigo "Bocão" participou de uma sessão em que o skatista que estava sendo filmado demorou aproximadamente 4 horas para acertar uma única manobra. Sabendo da oportunidade que tinha e, também, aproveitando-se de dois videomakers ali presentes, o praticante se esforçou ao máximo para filmar uma manobra nunca antes acertada no pico:

Teve uma vez... Não era nem um videomaker, eram dois. Eu e o "Gema". Encontrei ele depois e ele já estava no meio da sessão. Quem estava andando era o "Chaveiro". Ele estava finalizando a entrevista dele para a [revista] Cemporcento. Cheguei à sessão e o "Gema" já estava filmando há mais ou menos uma hora. Cheguei e comecei a fazer o segundo ângulo. Aí acabou a bateria do "Gema" e ficou a minha. O "Gema" trocou a bateria dele e ficou filmando. Acabou a dele e eu fiquei filmando. Aí ele correu num bar e deixou carregando. Aí acabou a minha bateria, ele voltou lá e pegou a bateria dele. Tinha mais um pouco de bateria e continuamos filmando. Acho que a sessão durou umas quatro horas. Isso foi na Lapa [região da cidade São Paulo]. Ele acertou a manobra. Cansado, mas acertou perfeito. Era uma manobra só no pico. Foi no terminal da Lapa. Foi um nosegrind saindo de nollie flip (Rodrigo "Bocão", entrevista em 11 de abril de 2011).

A maioria dos skatistas se sente mais encorajada a realizar manobras consideradas difíceis e a utilizar picos onde a prática é proibida no momento em que participam de

\footnotetext{
309 É importante destacar que o "fazer-se ver" no universo do street skate não se dá somente quando se realiza imagens. Por meio das competições disputadas, tal como apresentadas no Capítulo I, isso também pode ser feito.
} 
uma sessão cujo objetivo é a produção de imagens. Todavia, também há aqueles que nessas mesmas situações se sentem ansiosos por conta de diversos fatores, em especial, pela possibilidade de ser repreendido numa sessão onde o pico é privado ou por conta da dificuldade em acertar uma manobra de alto nível técnico em um pico público. A tensão vivenciada pelo skatista se reflete em sua performance, que muitas vezes não é adequada e nem eficaz no momento em que ele mais necessita ${ }^{310}$ :

Eu já fui com caras que eu tinha certeza que rolaria as fotos em certos lugares. O cara é muito bom, desce corrimão gigante. O cara fica 1 hora e meia olhando o corrimão e não consegue jogar uma vez. Já vi ele chorar, pedir desculpas e falar: "mano, não vai rolar, hoje não é o dia, não estou preparado!" ou "não vou mais voltar aqui!" (Marcelo "Mug", entrevista em 6 de abril de 2011).

Sessões mal sucedidas são recorrentes. Quando isso acontece, é comum os skatistas se sentirem culpados. Fotógrafos e videomakers, entretanto, devem estar preparados para lidar com os imponderáveis cotidianos a que seus respectivos trabalhos estão sujeitos:

As coisas que os skatistas ficam mais frustrados são quando eles não conseguem voltar a manobra. Eles pedem desculpa, eles não dormem direito à noite, eu sei disso. Eles ficam remoendo na cama: "por que eu não voltei aquilo?". É como você botar uma meta em sua cabeça e não conseguir atingir. Mas tem que voltar lá de novo e tirar essa pedra do sapato (Marcelo "Mug", entrevista em 6 de abril de 2011).

Eu, como fotógrafo, sempre falo... Para mim é tranqüilo ficar de dez minutos a cinco horas, porque meu trabalho é apertar botão. Já o cara está arriscando a vida dele, está se matando, literalmente. Então sempre falo para o cara ficar tranqüilo, que a gente tem todo o tempo do mundo, principalmente se o pico for tranquiilo. Para ele me esquecer ali e andar de skate como se estivesse com os amigos dele. Mas é impossível. Eu já fiquei do outro lado da câmera (com amigo, não era nem com profissional) e você fica tenso. Você sabe que tem uma pessoa ali esperando o melhor de você e você sabe que consegue aquilo, mas às vezes demora. Tem uma certa angústia, uma certa preocupação a mais. Não só entre você, o skate, a manobra e o pico,

310 O aspecto apresentado pode ser contextualizado com a situação vivenciada pelo skatista profissional Sandro Sobral na sessão realizada em um pico público, conforme já apresentado neste capítulo. 
mas você sabe que tem que dar uma satisfação a mais para uma pessoa que está trabalhando. Então com certeza deve ficar martelando: "pô, o Mug está ali. Preciso acertar bonito. Preciso fazer um 'bagulho' bem feito, porque tem pessoas esperando por mim" (Marcelo "Mug", entrevista em 6 de abril de 2011).

Conforme se pode perceber até aqui, é comum a presença de skatistas, fotógrafos e videomakers numa mesma sessão. A intenção é retratar a manobra e o pico de várias maneiras. E nessas sessões, é primordial a interação entre todos os participantes a fim de cada um respeitar o espaço e o trabalho do outro:

É importantíssimo o diálogo entre fotógrafo e videomaker. E o skatista também. Se a manobra é muito difícil, a gente sabe que o cara não vai acertar duas vezes, que ele não vai repetir para fazer dois ângulos, para uma o fotógrafo fazer e a outra o videomaker. Então a gente tem que ter essa consciência de que a gente é uma equipe. Se a gente não fizer a foto e a filmagem enquanto o cara está fazendo a manobra bem feita, o trabalho vai sair pela metade. E o skatista talvez não vá ficar feliz só com uma foto ou só com uma imagem. Então a gente tem que trocar idéia, saber esse lance: "vai fazer de tele ou fisheye? Vamos só botar o flash? O cara vai vim de onde? Ele vai vim de back ou de front para o corrimão? Vamos ficar cada um de um lado ou lado a lado? Fica um pouquinho mais para cima, senão você vai aparecer em minha foto. Ou então, deixa eu fazer o moment e depois você faz a imagem". Então é importante trocar idéia com o skatista e o videomaker, até mesmo antes de ir para o pico. Você sabe que o pico é proibido, então você fala: "vamos todo mundo fazer de fisheye, eu já chego e monto o flash antes. Você fica em cima da escada e eu fico no meio. O skatista já vai e dá de "prima",. Tem que ter esse diálogo, senão fica confuso e não rende o trabalho (Marcelo "Mug", entrevista em 6 de abril de 2011).

As imagens dos skatistas podem ser feitas de distintos modos. Tanto o fotógrafo quanto o videomaker optam por um ângulo e por um enquadramento que varia de acordo com a manobra e o pico em que a imagem está sendo feita. As imagens devem evidenciar não só o nível técnico do skatista, como também a paisagem em que ela está sendo captada, ou, para ser mais claro, "a interação do skatista com a cidade", conforme a fala de um interlocutor. Dessa maneira, a prática do street skate é retratada através de certa interpretação da cidade: 
Para uma foto ser boa, você tem que evidenciar a manobra, o moment e também evidenciar o lugar que está rolando toda a foto. Geralmente tento juntar tudo isso para formar tipo um quadro. O lugar que a pessoa está andando, junto com o moment, a luz, e aí forma uma foto boa. Acho que tudo é um conjunto (Caetano Oliveira, entrevista em 7 de abril de 2011).

As fotos que eu mais gosto, tanto as minhas quanto a de outros fotógrafos, são aquelas que conseguem mostrar a relação do skatista com o ambiente, com as pessoas que estão andando, com a cidade, com o pedestre, com o motorista, com o cara que está olhando pela janela, com a tiazinha que está tomando um sorvete, com o cara que está no ponto de ônibus... 99\% das fotos que eu gosto de skate não são só mostrando o skatista, a manobra e o obstáculo, mas mostrando essa relação que a gente tem com todo o ambiente em volta (Marcelo "Mug”, entrevista em 6 de abril de 2011).

Além dessa parte mais conceitual, há outros requisitos básicos que são compartilhados pelos responsáveis em produzir imagens de skate. Em se tratando de fotografia, estar atento à iluminação do local é primordial. Por isso muitos fotógrafos sempre carregam consigo tripés e flashes extras. Já em relação ao enquadramento da foto, é obrigatório apresentar a entrada e a saída do pico, ou, grosso modo, "de onde o skatista vem e para onde ele vai" no momento em que tenta a manobra:

Você tem que pegar a entrada, para mostrar de onde a pessoa está vindo. E a saída, para mostrar para onde ela vai. Isso é básico. E depois vem o moment. Independente da velocidade que ela estiver, você tem que capturar o moment da manobra. Cada manobra tem um moment. Tem diversos tipos de moments. Mas você tem que olhar a foto e falar: "ele está dando um flip. Um heelflip. Um kickflip". Identificar a manobra a partir da foto ali, dela estática. Daí tem a questão da luz, que é o principal. Tudo é luz em fotografia. Então você tem que ter uma luz boa para congelar, independente da velocidade que a pessoa estiver. Então tem que mostrar de uma forma bonita o lugar que está rolando a foto (Caetano Oliveira, entrevista em 7 de abril de 2011).

O que é mais importante numa foto de skate, conforme a fala de Caetano Oliveira, é a captação do moment, isto é, do momento de maior plasticidade do corpo do skatista quando faz uma manobra. Um bom registro desse rápido instante é aquele que permite ao leitor de uma revista descobrir, por meio da imagem congelada, qual manobra está 
sendo feita. Por conta do preciosismo, a publicação de imagens que não captaram o moment são logo descartadas ${ }^{311}$. Shin Shikuma, editor de fotografia, explica seus os critérios para seleção de uma foto:

É uma boa foto: que tenha uma composição bem pensada, uma luz bem realizada, tem uma manobra no ponto certo. Tudo isso você vê na foto e sente no primeiro olhar. Como editor, eu procuro olhar primeiro a foto sem esse olhar muito crítico. Mas com um olhar de um leitor. Essa primeira impressão para mim é importante. Depois eu vou esmiuçando os detalhes da foto, para ver se ela está bem realizada, bem focada, bem trabalhada. Mas é importante que o moment da foto esteja bem realizado dentro de uma composição (Entrevista em 12 de abril de 2011).

Além das fotos publicadas em moment, também há aquelas feitas em sequência. $\mathrm{O}$ fotógrafo geralmente opta por fazer fotos em sequência de vários frames quando a manobra realizada pelo skatista é considerada muito técnica, dificultando a captação do moment por conta dos diversos movimentos seguidos com o corpo ${ }^{312}$. Dessa maneira, quando o skatista opta por fazer um combo, isto é, uma combinação de manobras feitas de uma só vez, a opção mais desejável é fazer uma sequência:

Tem manobra que é muito complicada. Quando é mais técnica, quando você vai mandar, por exemplo, uma manobra na entrada, daí você vai escorregar e mandar uma manobra na saída. Então não tem como você congelar um moment. Daí eu faço a seqüência. É como se fosse um frame do vídeo. Mas é importante no mundo do skate ter uma seqüência ali, senão nunca ia dar para saber o que está rolando. Tem lugar que você vai e o pessoal não tem câmera que faz seqüência. E quando eles vêem que você faz seqüência, só querem fazer isso, nem que seja um ollie. Daí é até engraçado isso, porque o pessoal fica carente de seqüência. Na verdade, uma coisa depende da outra. Sempre tem que ter o vídeo para mostrar como saí a foto, como foi a parte de ação, como foi a foto registrada (Caetano Oliveira, entrevista em 7 de abril de 2011).

\footnotetext{
311 Muitas fotos publicadas em mídias não-especializadas geralmente são criticadas por não seguirem alguns dos critérios básicos apresentados. Diversas delas não captam o moment correto, além de não enquadrarem o pico em que a manobra está sendo feita.

312 Em sua análise sobre as revistas especializadas em skate e em surfe, Fortes $(2009,434)$ também ressalta que as fotos publicadas em sequiência têm o duplo objetivo de informar e "ensinar", pois dão um sentido de movimento e facilitam a compreensão de como realizar as manobras.
} 
Ao contrário dos fotógrafos, que tendem a ficar estáticos em um local, os videomakers geralmente fazem suas filmagens em movimento. Por conta disso, muitos possuem um skate com rodas maiores e mais macias que permite acompanhar o impulso dado pelo skatista para a realização da manobra ${ }^{313}$. Sendo assim, eles vão de skate atrás do praticante, segurando a câmera para fazer a imagem. O trabalho de um videomaker oferece alguns riscos ao corpo. Esse profissional precisa estar atento não só à filmagem, como também, à sua locomoção com o skate. Geralmente as imagens são feitas com a câmera posicionada de baixo para cima, o que faz com que sua postura fique muito inclinada. Isso pode levá-lo a perder facilmente o equilíbrio, resultando em tombos que trazem prejuízos não só ao corpo, como também ao equipamento. Rodrigo "Bocão" já se machucou diversas vezes enquanto filmava outros skatistas, tal como descreve na seguinte situação:

[Eu estava em] uma tour, que eu fui com os caras da Vibe. No primeiro dia de sessão, chegamos de tarde. Já começou errada a viagem. Quebrou o carro, fomos de ônibus, só chegamos no outro dia. Chegamos, jantamos e fomos dar um "rolê" de noite. Fomos para o estacionamento de um mercado, com chãozinho lisinho, perfeito para andar e remar. "Vamos filmar umas linhas, vamos filmar uns negócios”. Tinha lá uns carrinhos para pular, tinha banquinho que o Michel tinha levado. Eu estava filmando a linha do Michel e uma pedrinha achou a roda do meu skate e travou. Voei e zoei meu ombro. Fiquei o resto da tour inteira com meu ombro zoado e mais um mês. Quase rompi os ligamentos do meu ombro. Até hoje dói um pouco e tem alguma coisa diferente (Entrevista em 11 de abril de 2011).

Para produzir imagens consideradas de boa qualidade, fotógrafos e videomakers investem em diversos tipos de equipamentos. Câmeras, flashes, tripés, lentes, baterias, pilhas, cartões de memória e outros itens são quase que obrigatórios para os que trabalham na mídia especializada. Isso fica evidente quando eles saem para as sessões. Enquanto o skatista porta somente seu skate, muitos fotógrafos carregam duas ou mais mochilas pesadas com seus equipamentos. E preparar tudo para que a sessão seja feita não é uma tarefa simples:

\footnotetext{
313 Rodas maiores e mais macias facilitam a circulação do videomaker com o skate, reduzindo o risco de tombos.
} 
Como o skate é movimento, ação muito rápida, em muitos momentos você tem que usar flash. Se você não tem uma opção de luz muito favorável, você vai ter que utilizar flash. Então o fotógrafo de skate anda com uma parafernália absurda para quem fotografa na rua. É uma das poucas vertentes da fotografia que você tem umas duas ou três mochilas com muita opção de flash, lente, para você montar um estúdio na hora que você precisar, em poucos minutos, em qualquer lugar do mundo. É loucura. Às vezes, você fala para os caras que fazem [fotos de] moda, outras coisa, e eles falam: "meu, como você anda com tudo isso na rua? Como você coloca três flashes no meio de uma avenida?". Mas é um tipo de fotografia que exige essa super produção em poucos minutos em qualquer lugar (Marcelo "Mug", entrevista em 6 de abril de 2011).

Às vezes, uma foto requer a utilização de vários tipos de equipamentos. Portanto, segundo relatos dos próprios fotógrafos, eles estão acostumados a montar uma espécie de estúdio fotográfico nas ruas. Isso os leva a correr diversos riscos, pois seus equipamentos, muitos deles avaliados em altas quantias de dinheiro, estão sendo expostos a público:

Você está ali, chamando muita atenção. Ladrão fica de olho para roubar, a polícia vem ver o que você está fazendo, pessoas param em frente à câmera para olhar e você tem que falar para ela que está fazendo uma foto, e geralmente elas não entendem. É sempre complicado. Equipamento é sempre uma questão difícil. Você vai viajar, aí tem que despachar, é muito peso, tem que pagar excesso de bagagem (Caetano Oliveira, entrevista em 7 de abril de 2011).

Enquanto o skatista corre o risco de se machucar ou de ser repreendido por usar um pico em que a prática não é permitida, fotógrafos e videomakers, além dos aspectos já apresentados, correm o risco de assaltos, o que tem se tornado cada vez mais freqüente ${ }^{314}$. Marcelo "Mug” passou por dois momentos de tensão num curto espaço de tempo, conforme o seu relato abaixo:

As duas vezes foram em São Paulo. A primeira vez foi um furto. Eu estava na Praça da Sé, dentro de uma lanchonete, e a minha mochila estava a 30

\footnotetext{
314 Por conta disso, quase todos os fotógrafos e videomakers que atuam na mídia especializada contratam seguradoras.
} 
centímetros do meu pé. O cara [que furtou] não estava mais lá e ninguém viu quem foi o cara. É uma coisa típica de cidade grande, de oportunidade. Ele viu a gente andando na Sé uns dez minutos antes. Aí a gente foi comer um lanche. Acho que nessa ele já estava observando a gente. A gente não viu que estávamos sendo observados e o cara foi muito esperto, mandou ver e foi embora com todos os meus equipamentos. Eu estava sem seguro. Foi o baque da minha vida. E a segunda vez, cinco meses depois, comprando tudo de novo, me reerguendo, contando com a ajuda da revista, da família, dos amigos. [Mas] dessa vez [foi] com seguro, eu aprendi a lição. A gente estava em Santo André, numa praça tranqüila. Era a sexta ou sétima vez que eu ia naquele local fotografar. Nunca tinha acontecido nada com ninguém, nem para mim nem para os outros que tinham ido lá fotografar. Não era um lugar seguro, mas a gente estava numa situação em que estava se sentindo seguro. A gente estava há 1 hora e meia, duas, já nessa praça, quando vieram dois caras numa moto. Eles já vieram armados e causaram aquele pânico todo. Levaram as nossas câmeras. Na verdade eu tentei ir embora, pois eu estava um pouco longe da ação. Ele veio por um lado e eu estava em outro. Mas ele me ameaçou: "Volta!". Eu tive que me incorporar à galera do roubo. Mas tudo bem, tranqüilo (Entrevista em 6 de abril de 2011).

Com essas experiências vividas, "Mug" também reconhece os riscos que envolvem os trabalhos dos profissionais da mídia do skate:

Eu sei que não foi a primeira vez que eu fui roubado, e não vai ser a última. Infelizmente, eu sei disso. Eu monto um estúdio fotográfico todo dia na rua. Quem anda com relógio na rua já vai ser assaltado, imagine quem coloca três flashes, uma câmera...? Coloca 18 mil reais na rua para todo mundo ver, então eu sei que isso vai acontecer de novo, e vai ser de forma violenta de novo. O cara vai vir com arma, sempre vai ter um perigo nisso, assim como é perigoso andar no corrimão. Enfim, são os riscos da profissão (Entrevista em 6 de abril de 2011).

Skatistas, fotógrafos e videomakers são, portanto, importantes atores no universo do street skate paulistano. Eles alternam seus papéis conforme cada circunstância ${ }^{315}$, ao passo que também relativizam diferentes formas de riscos de acordo com o sentido atribuído à prática do skate.

315 Como quase todos profissionais do skate também são skatistas, em uma mesma sessão eles podem alternar seus papéis. Um fotógrafo, por exemplo, pode produzir as fotos de um skatista, e, em seguida, andar de skate junto com ele. 


\section{6 - O olhar skatista expresso em revistas e vídeos}

Ao atribuírem uma exacerbada importância à mídia especializada, muitos skatistas inspiram suas condutas naquilo que está sendo veiculado, considerado, muitas vezes, como algo que deve ser mais valorizado ${ }^{316}$. Se revistas e vídeos são constantemente acionados pelos interlocutores como algo de interesse, logo, para os objetivos desta pesquisa, essas referências não poderiam ser deixadas de lado.

Durante o trabalho de campo, tive a oportunidade de participar de duas situações relevantes que possivelmente ajudarão a compreender certos aspectos em torno da produção de imagens e da sua relação com os usos da cidade, a partir da prática do skate. Ao longo do mês de abril de 2011, participei de uma reunião de pauta tendo em vista a escolha de matérias que fariam parte de uma edição da Revista Tribo Skate. Além disso, fui convidado a presenciar o lançamento de um vídeo de skate, ocasião que reuniu diversos skatistas ansiosos pelas imagens que seriam divulgadas.

\subsection{1 - A pauta é o skate}

Fui informado por Marcelo "Mug" e Felipe Minozzi, ambos funcionários da Revista Tribo Skate, que na primeira semana do mês de abril aconteceria a reunião de pauta para discutir o conteúdo da edição de número $188^{317}$. Perguntei a eles se também poderia participar desse momento. Solícitos, eles não viram nenhum problema, e disseram que se eu quisesse participar, era "só colar".

Cheguei à redação da revista no dia e na hora marcada. Algumas pessoas já estavam presentes, como Fabio "Bolota" e Cesar Gyrão (editores), Shin Shikuma (editor de fotografia), Marcelo "Mug" (redator e fotógrafo) e Felipe Minozzi (redator). Apesar de suas diferentes funções, há algo em comum entre eles: todos são skatistas. As suas roupas, os seus códigos, as suas gírias e os relatos de suas experiências são bem parecidos. Esse fato se aproxima dos apontamentos feitos por Fortes (2009, 432-433) que, ao analisar aspectos em torno da mídia especializada do surfe e do skate, pondera

\footnotetext{
316 Contudo, ressalto que a mídia especializada em skate não se configura enquanto algo homogêneo, visto que as publicações “(...) revelam pontos de vista menos consensuais do que supostamente se imaginam, pondo em disputa maneiras multifacetadas de conceber e viver o domínio esportivo em questão" (Toledo, 2002, 161). Embora nessa citação Toledo (2002) se refira aos discursos construídos por especialistas e profissionais envolvidos com o universo do futebol, penso que a mesma possa ser articulada à mídia skatista, também notadamente heterogênea.

${ }^{317}$ Edição publicada em maio de 2011.
} 
que "o envolvimento com outras atividades, além da prática esportiva, freqüentemente era [e ainda é] a solução encontrada pelos adeptos para conseguir viver do esporte e manter-se próximo dele". O ambiente em que acontecia a reunião demonstra a centralidade do skate para os funcionários da revista. Havia shapes pendurados na parede, fotos de skatistas em quadros, pôsteres dobrados, rodas enfeitando uma estante, adesivos de marcas especializadas colados em notebooks, entre outras coisas. Como um dos presentes disse, "aqui respiramos skate o tempo todo".

Após alguns instantes chegaram Fellipe Francisco e Heverton Ribeiro, também fotógrafos da revista. Com a maioria do staff presente, o editor Fabio "Bolota" iniciou a reunião. Mas antes de tratar de questões editoriais, outras coisas precisavam ser resolvidas. A primeira delas era em relação à captação de anúncios. De um modo geral, a produção de revistas impressas não tem sido fácil. Com o advento da Internet, muitos anunciantes não querem investir somente nesses tipos de publicações, já que outra opção mais viável são as estratégias de marketing feitas de forma virtual. Os editores esclareceram a importância de cada vez mais se adequar ao modelo vigente. Para isso, decidiu-se que um dos focos a partir da reunião seria o investimento no site da revista, que deverá ser alimentado com inúmeras informações diárias, priorizando sobretudo fotos e vídeos, pois são coisas que os "skatistas gostam de ver" 318.

Em seguida, o conteúdo editorial foi intensamente debatido e questionado. A forma como certas informações estavam sendo transmitidas precisava ser reavaliada. Nas colunas que compõem a revista, por exemplo, os textos devem ser mais curtos, com idéias objetivas e linguagem simples. Além do mais, paralelo ao texto é preciso ter imagens ou ilustrações que façam referência ao universo do skate. As entrevistas extensas também têm incomodado os redatores; não por conta de seu conteúdo, mas pela falta de qualidade de algumas imagens, o que pode comprometer toda a entrevista publicada. Desse modo, uma solução seria a diminuição do espaço destinado a essa seção, o que possibilitaria a seleção das melhores fotos e também, de modo mais amplo, o enfoque de outras pautas na edição.

Outro ponto debatido foi o critério de publicação de fotos. Para que um skatista encontre espaço nas páginas da revista, suas manobras têm de ser inéditas e com nível técnico elevado. Segundo um dos presentes, "o cara tem que se coçar", ou seja, o praticante precisa se esforçar para provar que realmente mereceu o espaço. Foi citado

${ }^{318}$ Expressão usada com base no discurso deles próprios. 
até um caso de um skatista profissional que esteve na redação para apresentar seu trabalho por meio de algumas imagens. Embora as fotos não fossem tão ruins, as manobras enfocadas não eram inéditas, já que o skatista comumente as realizava com facilidade em qualquer pico. Logo, seu material foi barrado.

Algo que ficou evidente na reunião foi a perda de importância dos campeonatos na publicação impressa. Na visão dos redatores, o espaço destinado aos eventos é o site, onde as atualizações de notícias são feitas com freqüência. As exceções devem acontecer somente quando acordos comerciais forem feitos, o que implica na divulgação da ação promovida pela marca anunciante. Caso a publicação seja feita, o ideal é que o enfoque seja dado de uma forma inusitada, demonstrando não apenas a competição em si, mas o que acontece nos bastidores, as curiosidades, as pessoas que estiveram presentes etc. Ao se referir à falta de visibilidade dos campeonatos na revista, Felipe Minozzi disse que:

\footnotetext{
Tem internet hoje, e não tem como fugir disso. Hoje em dia você assiste campeonatos ao vivo na internet. Daí você não vai querer ver de novo na revista. Então você tem que ter uma boa cobertura na Internet, que é mais rápida, tempo real praticamente. E tem que focar nisso. Para a revista ficar interessante, para você ver e comprar, você tem que criar coisas exclusivas para pôr na revista impressa. Uma coisa que o cara só vai ver se ele tiver a revista em mãos. É uma evolução natural e a Internet fez isso (Entrevista em 14 de abril de 2011).
}

A revista também possui um compromisso com a valorização dos skatistas profissionais. A cada ano há uma diminuição de praticantes na categoria, sobretudo na modalidade street skate. Segundo os interlocutores, muitas marcas especializadas que deveriam incentivar o profissionalismo, para conter seus custos, preferem patrocinar skatistas amadores. Em vez de pagarem um bom salário a um profissional, optam por investir em novos talentos, com apoio financeiro bem menor. Os editores concordam que os amadores devam ter seus espaços na revista, embora a prioridade sejam os profissionais. Ademais, ainda há uma questão comercial, visto que os skatistas dessa categoria são patrocinados por marcas que possivelmente anunciam na revista.

As imagens das manobras feitas devem ocupar quase todos os espaços das revistas e por meio delas é preciso demonstrar não só o lado esportivo do skate. Algo que perpassou os discursos ali proferidos foi a necessidade de se fazer fotos que 
desvinculem a imagem do skatista de um "atleta". Isso tem se refletido em muitas matérias publicadas, retratando skatistas fumando, bebendo, participando de festas, entre outras coisas que fazem parte das experiências socialmente compartilhadas no universo do skate.

A segunda parte da reunião foi coordenada por Cesar Gyrão, outro editor da revista. Inicialmente foi feita uma profícua discussão em torno da produção de fotos. Shin Shikuma, editor de fotografia, entregou a cada fotógrafo uma folha contendo dados a respeito de quantas imagens foram publicadas por cada um no ano anterior. Todos discutiram seus respectivos desempenhos e dialogaram sobre as dificuldades de se fazer fotos de skate. Ficou claro, principalmente a partir dessa conversa, que muitas matérias publicadas são pensadas a partir das fotos, e não dos textos.

Tendo em vista as demandas dos anunciantes, muitos pontos da reunião abordaram o que os editores chamam de "entregas comerciais", ou seja, as pautas destinadas às marcas que anunciam. Geralmente os skatistas patrocinados pelas marcas anunciantes possuem prioridade na revista. Prova disso foi uma lista feita com vários nomes que possivelmente seriam entrevistados, e seus respectivos patrocinadores.

Quase todas as matérias feitas em uma edição são voltadas para o street skate, modalidade que detém a preferência dos leitores. Nesse sentido, as pautas devem conter fotos que demonstrem o máximo de picos e manobras diferentes. Na busca por materiais inéditos, os fotógrafos da revista têm-se dedicado cada vez mais a viajar para outros estados ou países. Para a edição em pauta, discutiu-se a possibilidade de se fazer uma matéria sobre o cenário do street skate japonês após os desastres naturais que assolaram o país ${ }^{319}$. Shin Shikuma, descendente de japoneses, ficou responsável por entrar em contato com representantes da mídia especializada do Japão.

Ainda em relação ao street skate, é inegável que as imagens passíveis de serem publicadas têm de ser feitas em picos encontrados nas ruas. Fotos em pistas dessa modalidade não são valorizadas. Por outro lado, somente em modalidades como bowl, banks e vertical que as fotos em pistas são mais aceitas. Em prol de um equilíbrio nas pautas, surgiu a idéia de se fazer entrevistas com verticaleiros ${ }^{320}$ e também uma matéria especial sobre as inúmeras pistas de concreto (bowl e banks) da região do Vale do

\footnotetext{
319 Em março de 2011 vários desastres naturais, como terremotos e tsunamis, aconteceram no Japão, resultando em milhares de mortos e desaparecidos.

${ }_{320}$ Verticaleiros são os skatistas adeptos da modalidade vertical, praticada em um half pipe (rampa em formato da letra "U").
} 
Paraíba - SP. Como o street skate ocupa quase todo o espaço da revista, demonstrar essas outras modalidades seria uma boa iniciativa.

Os redatores sugeriram uma pauta que visava enfatizar como a prática do skate pode ser feita por várias gerações diferentes. Para ilustrar a matéria, o enfoque seria dado à família do skatista Jefferson "Bill". Tanto ele, quanto seu pai e seus dois irmãos são skatistas, e se auto-intitulam como "fun family". Além disso, no sentido de dar espaço a skatistas que não possuem patrocinadores, o fotógrafo Heverton Ribeiro se propôs a fazer imagens de um skatista morador da Zona Leste, cuja trajetória de vida é bem problemática. A intenção da matéria seria demonstrar como o praticante conseguiu superar diversas adversidades de sua vida por meio da prática do skate. Os presentes na reunião gostaram da idéia, embora ela não pudesse ser posta em prática na edição que estava sendo discutida.

Conforme se evidenciou, um dos objetivos da revista é abordar a heterogeneidade do skate. Para tanto, Marcelo "Mug" idealizou uma matéria com uma crew de amigos da categoria mirim, chamada Smith Grinders. Os garotos dessa crew se destacam por conta de suas imagens produzidas, as quais apresentam um considerável nível técnico para skatistas com apenas pouco tempo de prática. Suas atitudes chamaram a atenção dos redatores, que não queriam perder tempo para enfocar os futuros talentos do street skate. Heverton Ribeiro ficou a cargo de fazer as fotos dos garotos. Embora eles sempre freqüentem a pista do Sumaré, as imagens deveriam ser feitas nas ruas para mostrar o lado streeteiro das jovens promessas.

Após um tempo a reunião termina. De modo geral, notei que a cada edição a Revista Tribo Skate procura abordar muitos temas que vão muito além da prática em si. Música, arte, comportamento, entre outros assuntos, ganham espaço na publicação, que tenta, por meio de suas páginas, trazer para si a legitimidade de muitos discursos construídos no universo do skate brasileiro ${ }^{321}$.

\footnotetext{
321 Vale salientar que além da Tribo Skate, há outras revistas especializadas em circulação no Brasil (como as revistas CemporcentoSkate e Vista). Cada uma delas possui uma linha editorial específica, com discursos construídos em torno da prática do skate conforme suas próprias perspectivas. Na visão de Fortes $(2009,434)$, cada revista especializada em skate procura determinar de sua forma "o que é certo ou errado, desejável ou indesejável; que comportamentos são convenientes ou inconvenientes etc." e para isso, as publicações são responsáveis por dar dicas de vários assuntos: “(...) como andar, onde andar, como se comportar na rua, como se portar frente a outros skatistas, segurança, primeiros socorros". Portanto, assim como a mídia responsável por cobrir os acontecimentos do universo do futebol, tal como analisada por Toledo (2002), a mídia especializada em skate, obviamente com seus distanciamentos em relação a essa última, produz "versões de um mesmo fenômeno, feixes de significados que norteiam lógicas simbólicas de práticas sociais concretas, muitas vezes contraditórias entre si” (Toledo, 2002, 283).
} 


\subsection{2 - Skate no cinema}

Em plena noite de uma segunda-feira, o Cine Olido (localizado ao lado da Galeria do Rock, no centro de São Paulo) seria palco para a première de mais um vídeo de skate $^{322}$. Esse local, nos últimos tempos, passou a exibir inúmeras produções feitas por skatistas de diversas partes do país e do mundo. Acostumados às exibições gratuitas, os praticantes aguardam ansiosamente pelos novos lançamentos que freqüentemente acontecem.

Durante o mês de abril de 2011, ocorreu o lançamento mundial do vídeo intitulado Since Day One, promovido pela marca norte-americana Real Skateboards. Jorge Costa, interlocutor da pesquisa, esteve envolvido com a organização do evento e por conta disso fez questão de me convidar. Confirmei a minha participação, fornecendo meus dados que deveriam ser conferidos na portaria do cinema, antes da exibição. Quem não estivesse com o nome na lista, segundo os organizadores, não entraria em hipótese alguma.

Fui de carona com Shin Shikuma para o evento. Após alguns minutos no trânsito, chegamos ao centro da cidade. A exibição do vídeo estava prevista para 19h30min, porém, como estávamos atrasados, fomos rapidamente para o cinema. Mas ao chegarmos lá, não havia nenhum sinal de que a exibição aconteceria naquele instante, pois os convidados ainda estavam chegando. Havia uma grande aglomeração de skatistas no local. Shin Shikuma logo encontrou alguns amigos também fotógrafos atuantes na mídia especializada. Durante certo tempo, eles trocaram diversas informações ligadas às suas respectivas funções.

Encontrei vários interlocutores contatados ao longo do trabalho de campo. Muitos deles são locais do Vale do Anhangabaú. Por estarem quase todos os dias na região central, dificilmente perdem os lançamentos de vídeos de skate no Cine Olido. Também estavam presentes integrantes de várias crews distintas, como Lixeira, KDC, Mogi Crew, Beats, etc. Nas ocasiões em que muitos skatistas se reúnem, a sociabilidade se alarga e se torna mais densa. Nessas circunstâncias, não basta ter somente um considerável nível técnico para ser reconhecido. Com efeito, é preciso sempre comparecer nesses eventos sociais promovidos e participar das diversas experiências neles vivenciadas. Partindo da perspectiva dos interlocutores, isso evidencia que para a

322 O Cine Olido fica na Avenida São João, 473. 
pessoa ser considerada e respeitada como skatista é necessário não só praticar, mas também fazer parte das redes de relações que perpassam tal universo.

Eram quase 20h30min quando os presentes começaram a entrar. Mas vários skatistas que estavam ali não foram convidados, e, portanto, não tinham o nome na lista. "Evento de skate sabe como é, né...? Não tem como barrar!", foi o que disse um jovem ao meu lado. E foi o que de fato aconteceu. Utilizando-se de várias estratégias, quase todos conseguiram entrar. Por mais que muitos não tenham recebido o convite, conheciam pessoas que foram convidadas e que tinham contatos com os organizadores do evento. O próprio Shin Shikuma, por exemplo, não tinha o nome na lista, mas conhecia Masterson "Magrão", skatista profissional patrocinado pela Real Skateboards, que facilitou sua entrada na exibição do vídeo. E o mais inusitado era que vários outros skatistas, aproveitando-se da entrada desse fotógrafo, foram atrás dele alegando ao segurança da portaria que também conheciam o referido skatista profissional, o que não era verdade.

Após confirmar meu nome na lista, fui em direção à sala do cinema. No caminho encontro Ari Bason, skatista profissional e gerente comercial da Plimax, distribuidora de produtos para skate responsável pela exibição do vídeo no país. Ao seu lado havia uma pessoa fotografando os presentes. Próximo a ela havia alguns stands de marcas especializadas, que expunham vários tipos de produtos, como tênis e peças para skate. Os funcionários que estavam nos stands ainda presenteavam os skatistas com alguns brindes, como bonés e chaveiros.

No hall do cinema, diversas aglomerações se formavam. Havia uma intensa troca de informação. Os presentes comentavam sobre suas últimas sessões, as fotos e as filmagens que tinham feito, dos campeonatos que seriam realizados, dos picos encontrados pela cidade, enfim, sobre inúmeras experiências ligadas ao cotidiano dos streeteiros. Como vários fotógrafos e videomakers também estavam no local, os praticantes aproveitavam para marcar sessões com eles. No instante em que encontrei Marcelo "Mug", por exemplo, ele combinava de fazer fotos dos skatistas Ricardo "Dexter" e Murilo Romão, em picos descobertos por eles.

Finalmente a sala do cinema foi liberada. Na entrada, ganhamos mais brindes: um pote repleto de balas, distribuído a todos. Rapidamente as poltronas foram ocupadas. $\mathrm{O}$ local estava muito cheio. Algumas pessoas, inclusive, tiveram que se sentar no chão. Antes da exibição imperava um clima de descontração entre os skatistas. Frases eram ditas em voz alta, gritos eram dados, piadas eram feitas. De repente Ari Bason surgiu 
com um microfone, saudando os presentes. Ele então começou a explicar brevemente as estratégias de marketing da marca promotora do evento. Após isso, fez uma homenagem ao skatista Willians "Indião", que falecera dias antes. Nesse instante todos bateram palmas e assobiaram.

Enfim chegou o momento mais esperado. As luzes se apagaram e o vídeo começou a ser exibido. Em seu roteiro, não havia nenhuma história a ser contada. Por se tratar da promoção de uma marca, o vídeo é dividido em várias partes que variam entre três a cinco minutos, as quais mostram o nível técnico de cada skatista patrocinado. Em cada uma delas aparecia um único praticante mandando o máximo de manobras possíveis em inúmeros picos diferentes. Para dar sentido às filmagens, cada parte ainda tinha uma música de fundo, sendo a maioria no estilo rap ou punk rock.

As imagens do vídeo refletem a prática do skate nas ruas: estratégias para andar em picos cujo acesso é proibido, confusões com policiais e seguranças, inúmeras tentativas de manobras consideradas difíceis, etc. Embora a maioria das filmagens se passe nos EUA, as experiências são bem parecidas com as vivenciadas no universo do street skate paulistano.

À medida que o vídeo transcorria, as partes que envolviam skatistas ficavam mais empolgantes. Quase todas foram feitas nas ruas. Em apenas poucos momentos apareciam imagens feitas em pistas. De todo modo, elas faziam referência às modalidades vertical, bowl e banks. As melhores manobras acertadas pelos skatistas no vídeo eram comemoradas pelos presentes no cinema. Eles assobiavam, batiam palmas e gritavam a típica expressão “yeah!”. Aquele instante se tornava muito efervescente.

Após muito barulho, depois de quase uma hora de exibição, o vídeo finalmente terminou. As luzes se acenderam e rapidamente todos saíram da sala do cinema. $\mathrm{O}$ hall novamente tornou a ficar cheio. Todos faziam suas respectivas avaliações de cada parte do vídeo, falando de suas preferências e de quais skatistas fizeram as melhores manobras, bem como criticando as que não foram contagiantes. Havia vários fotógrafos no local fazendo fotos para sites da mídia especializada. E muitos presentes demonstravam interesse em aparecer nas imagens, afinal, ser visto é uma condição essencial para a carreira de muitos skatistas.

Já eram mais de 22 horas. Alguns skatistas, aproveitando-se do encontro, foram tomar cervejas em um bar das redondezas. Mas como era segunda-feira, muitos optaram por ir embora, tendo em vista os compromissos pessoais a que estavam sujeitos no dia seguinte. E assim foi mais uma exibição de um vídeo de skate no Cine Olido. Salas 
lotadas, clima efervescente, uma densa sociabilidade estabelecida e diversos tipos de experiências compartilhadas.

Em capítulos anteriores foram apresentados alguns discursos, por parte do poder público, que incentivam a participação dos skatistas em campeonatos e a prática do skate em pistas. Neste capítulo, por sua vez, evidenciou-se os discursos da mídia que, ao contrário do poder público, atribuem valor não só às competições e as pistas, mas, sobretudo, a produção de imagens e ao skate praticado nas ruas, ou melhor, em picos. Isso demonstra, pois, a heterogeneidade de sentidos que perpassa o universo do street skate paulistano e, por conta disso, é possível compreender como a prática do skate abrange vários domínios da vida de muitos skatistas, se apresentando de diferentes formas conforme a situação, seja como uma "diversão", um "trabalho", ou como a união do "útil ao agradável", conforme a expressão utilizada por Alexandre "Nicolau". Por fim, pode-se compreender também como os espaços urbanos são vistos e apropriados a partir do olhar skatista e como as ações desses citadinos - para usar uma expressão de Agier (2011) - "fazem a própria cidade".

\section{ICONOGRAFIA - CAPÍTULO III}

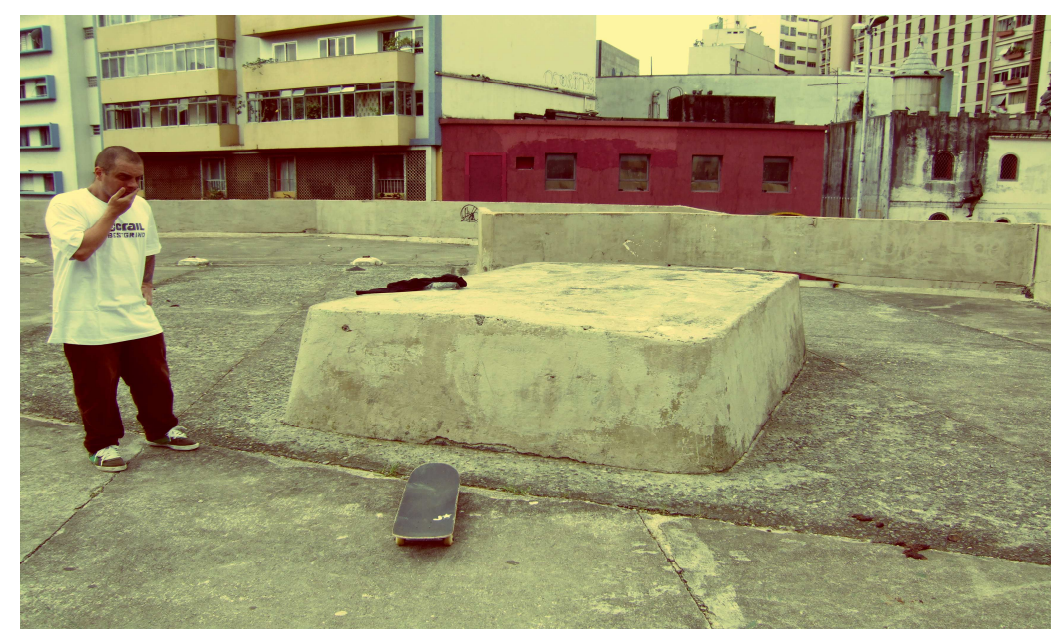

Sandro Sobral imagina as possíveis manobras que podem ser mandadas no pico (foto: G. Machado) 


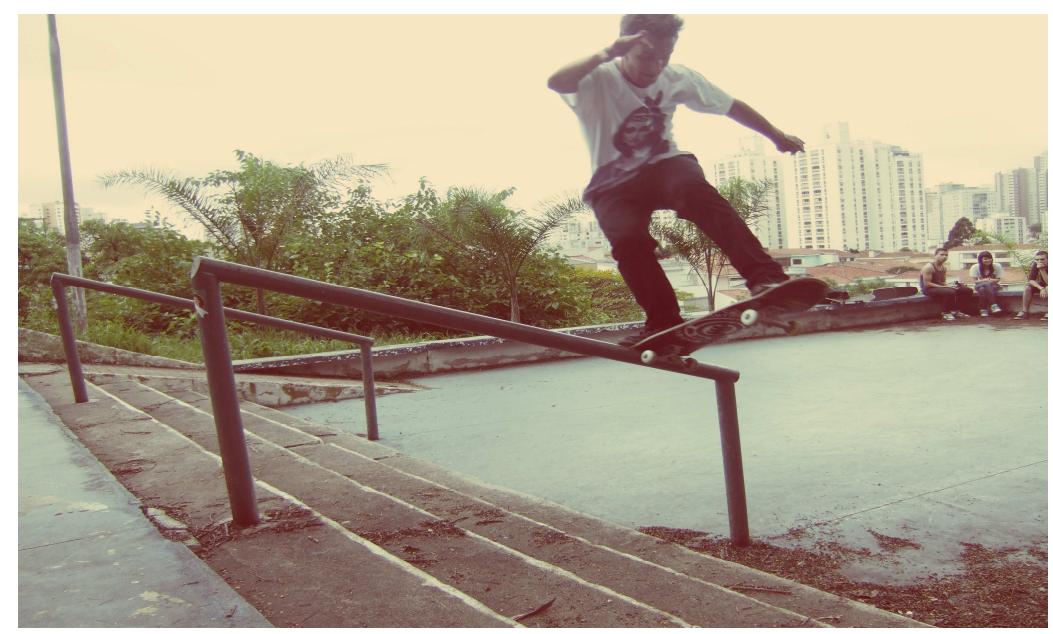

O skatista Lucas "Xaparral” realiza uma manobra em um pico (foto: G. Machado)

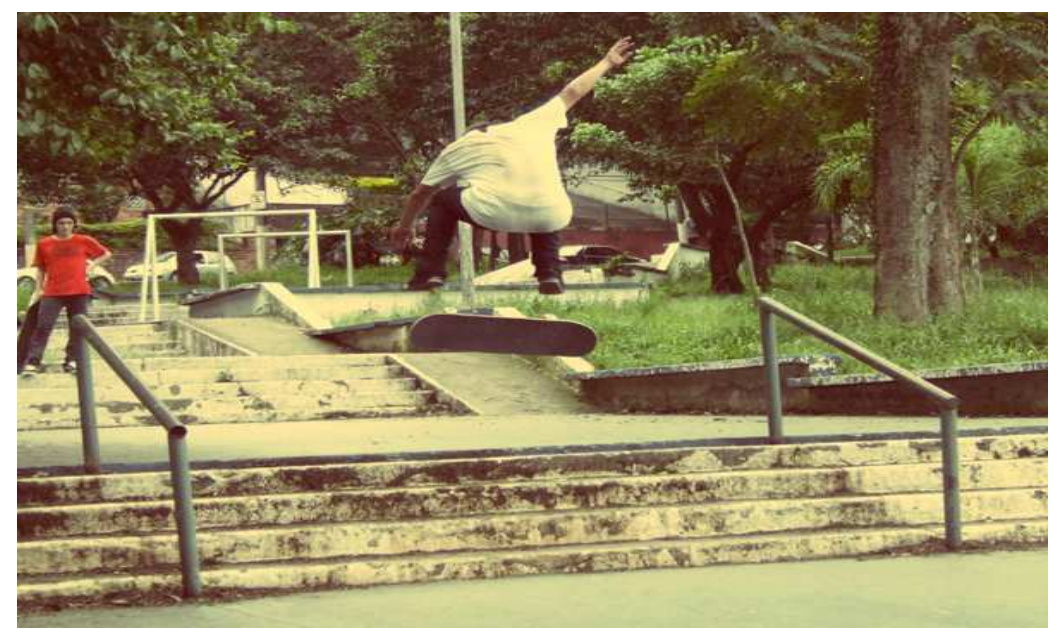

As escadas de uma praça tornam-se obstáculos (foto: G. Machado)

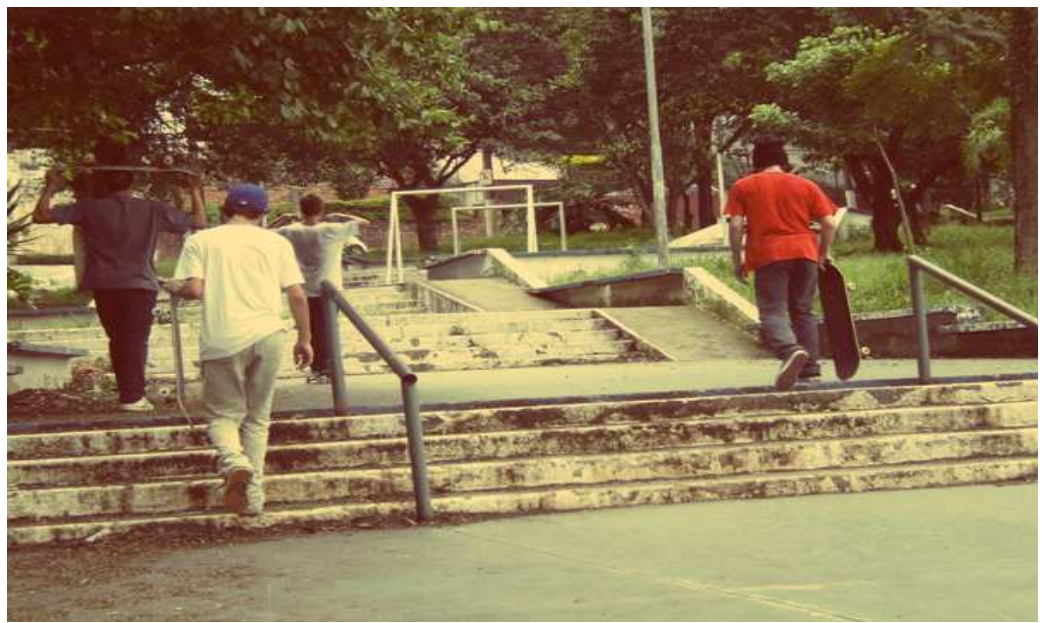

Skatistas reunidos numa sessão realizada na Blue Square, em Perdizes (foto: G. Machado) 


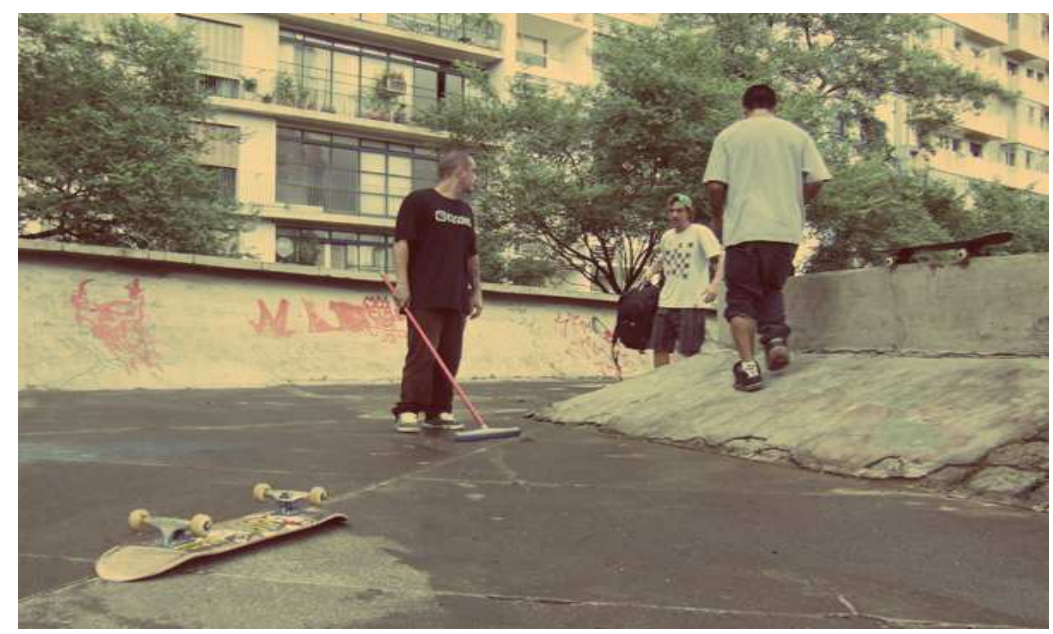

Sessão na Praça Roosevelt (foto: G. Machado)

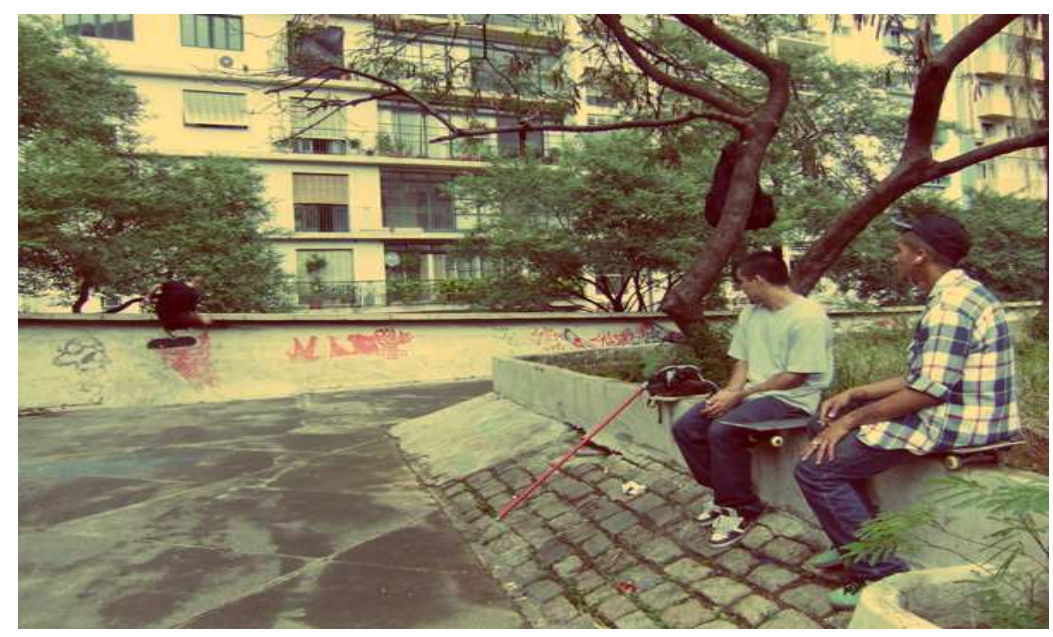

Skatistas observam Sandro Sobral (foto: G. Machado)

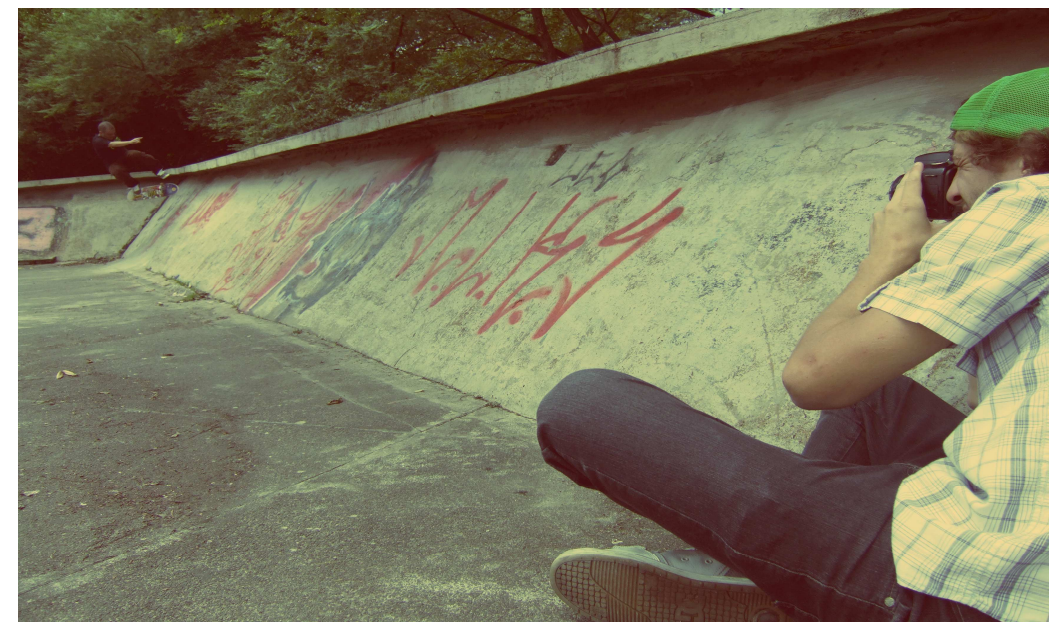

O fotógrafo Marcelo “Mug” e o skatista Sandro Sobral (foto: G. Machado) 


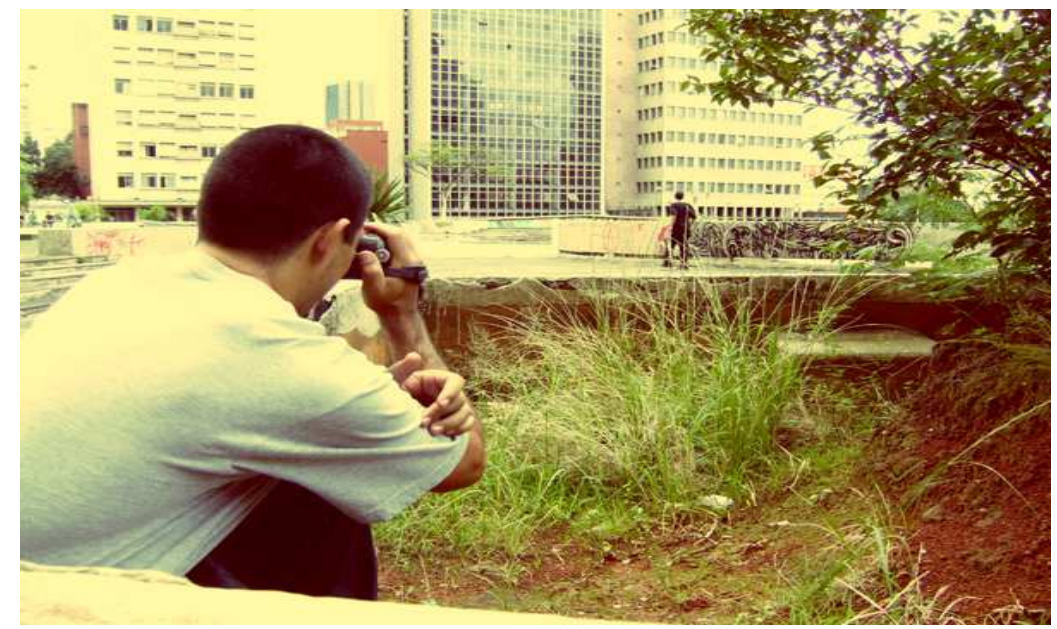

Alexandre "Nicolau", com a filmadora em mãos, registra a sessão (foto: G. Machado)

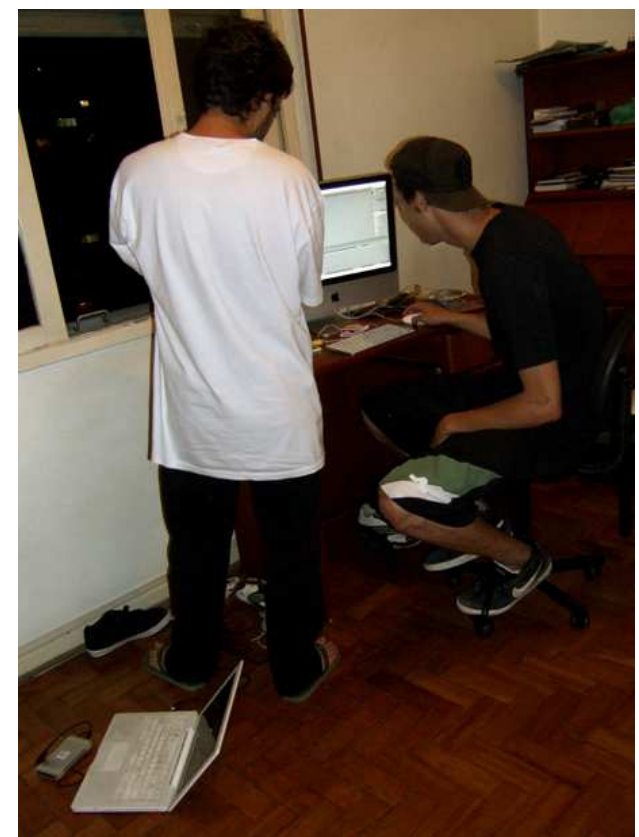

Victor Ferrari e Daniel Santi editam suas filmagens para a produção de um vídeo de skate (foto: G. Machado) 


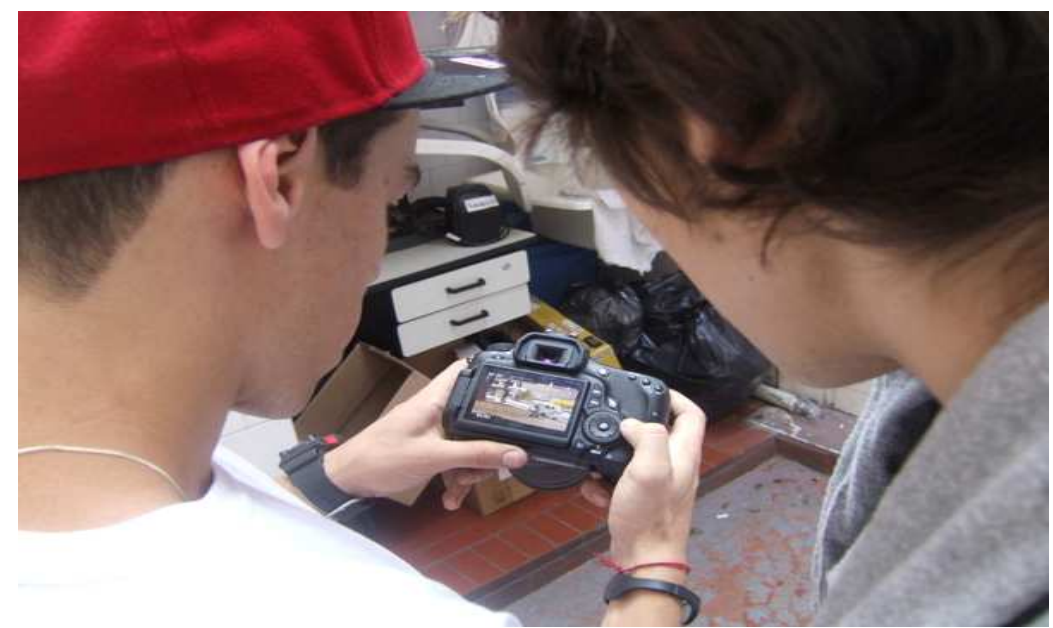

Rodrigo "Bocão" e Marcelo "Dohdoh" conferem as imagens das manobras na câmera (foto: G. Machado)

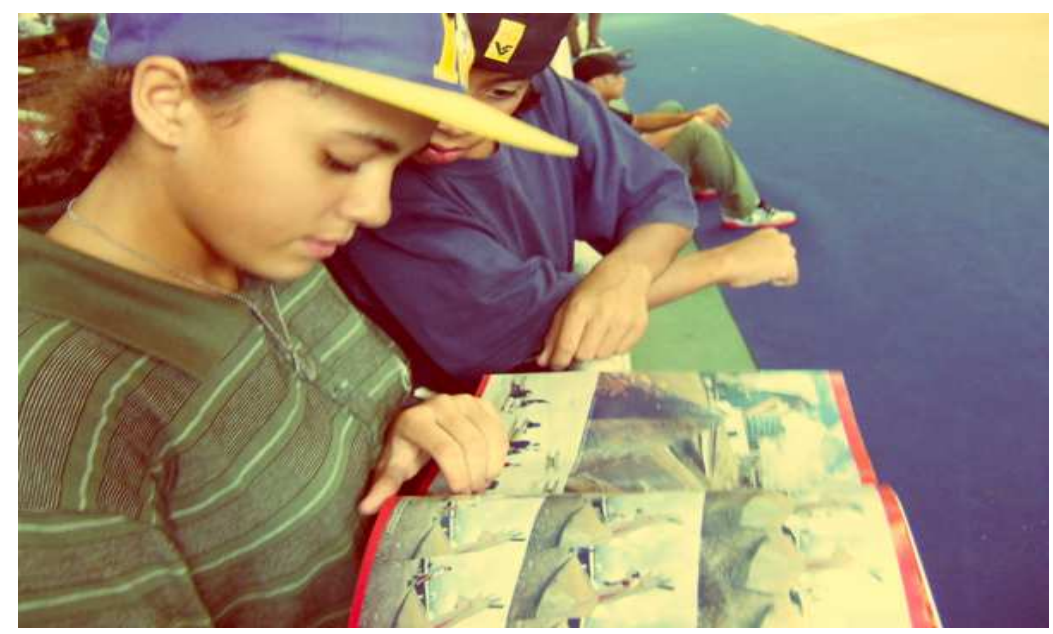

Skatistas observam as fotos em uma revista especializada (foto: G. Machado) 


\section{Considerações finais}

\section{"Dá para tirar os skatistas das ruas?"}

Devido à sua centralidade, a Avenida Paulista tornou-se um dos locais mais disputados pelos streeteiros paulistanos. Dada a pretensão de muitos deles de conhecer os novos picos que surgiram a partir da substituição do piso de pedra portuguesa, a intensa utilização dos equipamentos urbanos rapidamente tomou grandes proporções. Conseqüentemente, alguns jornais destacaram o fato:

Reformadas, com pavimento lisinho e de concreto, as calçadas da Avenida Paulista atraem cada vez mais skatistas em busca de manobras radicais, lazer e treinamento para campeonatos. Desde o início das obras, há um ano, é comum vê-los desviando de pelo menos 1,7 milhão de pessoas que circulam diariamente pelo local. O ziguezague dos esportistas assusta os desavisados. Mas, segundo a Subprefeitura da Sé, não há lei que impeça os skatistas de andar nas novas calçadas da Paulista, cujo custo de reforma está orçado em $\mathrm{R}$ \$ 8,1 milhões. Mas pode haver limite. A subprefeitura avisa que, se houver dano ao patrimônio público, a administração "agirá no sentido de coibir ou educar os esportistas" (Jornal da Tarde, 11 de julho de $2008^{323}$, grifos meus).

Para a maioria dos praticantes, andar de skate nos picos pode se constituir ora como uma "diversão", ora como um "trabalho". Para muitas outras pessoas, ao contrário, essa mesma prática às vezes pode ser vista como uma arruaça, um ato de vandalismo, uma perturbação da "ordem". Desse modo, a convivência entre skatistas e outros citadinos no contexto da Avenida Paulista nem sempre é pacífica, podendo tornar-se, inclusive, caso de polícia ${ }^{324}$.

A situação apresentada na citação acima é apenas uma entre várias onde há uma tentativa de negociação pelos usos dos espaços urbanos. De acordo com a matéria do jornal, se por um lado temos a presença cada vez mais constante de skatistas, que fizeram da Avenida Paulista um local privilegiado para a prática do skate, por outro,

323 Disponível também em http://txt.jt.com.br/editorias/2008/07/11/ger-1.94.4.20080711.25.1.xml. Acesso em 29 de maio de 2010.

${ }^{324}$ Para uma análise mais detida sobre distintas formas de ocupação da Avenida Paulista, vide Frúgoli Jr. (1996) e Oliveira (2000). 
temos a atuação do poder público, no intuito de limitar algumas formas de apropriação dos espaços. Portanto, em um plano mais amplo, partindo do pressuposto de Frúgoli Jr. $(1995,34)$, esses fatos reverberam uma característica do cotidiano dos grandes centros urbanos: a coexistência de relações de conflito, uma vez que se cruzam visões e práticas diferenciadas.

Em função das constantes reclamações dos moradores da Avenida Paulista, e também com a publicação da já mencionada matéria "Av. Paulista vira pista de skate" pelo Jornal da Tarde (11 de julho de 2008), o vereador Adolfo Quintas (PSDB) formulou o projeto de lei $\mathrm{n}^{\circ} 116 / 2009$, de 05 de março de 2009, acrescentando o inciso XXVI ao artigo $1^{\circ}$ da lei $10.328^{325}$, que dispõe sobre as infrações administrativas:

Fica expressamente proibido no território do município de São Paulo: utilizar "skate" nas calçadas, exceto área reservada para este fim, na forma da regulamentação a ser expedida pelo Executivo (Disponível em http://www.camara.sp.gov.br/projintegrapre.asp?fProjetoLei=116\%2F09\&s TipoPrj=PL. Acesso em 19 de dezembro de 2009).

Para a elaboração desse projeto de lei, o vereador Adolfo Quintas alegou que a prática do skate pode danificar os equipamentos públicos da cidade, e em virtude disso, cabe à administração pública zelar pelos patrimônios ${ }^{326}$. Ademais, tendo em vista a aprovação dessa propositura, o referido vereador entende também que a prática nas calçadas da Avenida Paulista traz riscos aos outros pedestres que por lá circulam ${ }^{327}$, em especial, os idosos:

Não obstante se entenda o caráter necessário da prática do esporte em tela, ou seja, o skate, temos que salientar que além dos fatos aqui narrados, o Brasil hoje é considerado um país formado na sua maioria por idosos, notoriamente na cidade de São Paulo, onde este número supera as demais cidades de nosso país. Ora o trânsito de pessoas idosas cumulado com a

\footnotetext{
325 Lei de 03 de junho de 1987.

326 Para mais detalhes sobre o projeto de lei $n^{\circ} 116 / 2009$, vide Anexo E.

327 Frúgoli Jr. $(1995,15)$ salienta que os espaços públicos são alvos de intensas intervenções visando priorizar, sobretudo, o fluxo. Partindo desse princípio considera-se que diversos tipos de apropriações de certos espaços são banidos ou excluídos. No contexto pesquisado, o street skate, para alguns agentes, constitui uma prática que, além de deteriorar os equipamentos, atrapalha a circulação de pedestres pelas calçadas. Portanto, conforme apontado por Frúgoli Jr. (2000, 21), “é necessário atentar para a diferença que há entre premissas e intenções de determinados projetos urbanos e suas realizações concretas, já que a complexidade da conexão entre as intenções técnicas e as decisões políticas pode resultar em diversas formas de exclusão social, mesmo dentro de projetos, a princípio, igualitários”.
} 
prática do skate tem levado riscos a toda classe etária, porém os idosos é quem sofrem mais, já que caso ocorra um acidente sua recuperação levará mais tempo, isto sem mencionar os casos em que as seqüelas são irrecuperáveis, gerando, destarte, despesas ao município e a sua coletividade imensuráveis (Gabinete Vereador Adolfo Quintas. Justificativa Projeto de Lei 116/09. Disponível em: http://camaramunicipalsp.qaplaweb.com.br/iah/fulltext/justificativa/JPL0116 -2009.pdf. Acesso em 27 de janeiro de 2011).

Dessa maneira, as calçadas e muitos equipamentos urbanos são basicamente definidos como espaços de circulação, e não de agrupamento (Oliveira, 2000, 217) ${ }^{328}$. Com base nessas justificativas, a deliberação foi aprovada em primeira discussão na Câmara, através de sessão extraordinária em 4 de agosto de 2010. A penalidade para a utilização do skate nas calçadas foi estabelecida - a partir do parecer da Comissão de Constituição, Justiça e Legislação Participativa ${ }^{329}$ - por meio de uma multa de aproximadamente $\mathrm{R} \$ 92,00$, podendo ser dobrada em caso de reincidência. Desse modo, de acordo com o que fora proposto, um dos únicos espaços públicos da cidade em que a prática do skate não estaria sujeita a multas seria a pista.

A partir do momento em que os skatistas souberam das medidas que possivelmente seriam impostas, iniciou-se um amplo protesto feito pela Internet. A mídia especializada posicionou-se contra a atitude de Adolfo Quintas, bem como incentivou os leitores a enviarem inúmeras mensagens às redes sociais pertencentes ao vereador:

Ontem, dia 4 de agosto, a Câmara Municipal aprovou o projeto que proíbe o skate nas calçadas de São Paulo. (...) O projeto passará por uma segunda votação antes de chegar ao prefeito Gilberto Kassab, que poderá sancioná-lo ou vetá-lo. O ilustre vereador do qual partiu a idéia é Adolfo Quintas, que resolveu proibir o skate com base nas reclamações de pedestres de áreas com grande movimento, principalmente da Avenida Paulista. Parece-me que o skate ainda é visto, por muita gente, como brincadeira de criança, e que paira no ar a idéia de que proibi-lo não vai gerar conseqüência nenhuma. (...)

\footnotetext{
328 Ao fazer um breve resgate histórico da tentativa de proibições de certas práticas no contexto da Avenida Paulista, Oliveira $(2000,221)$ postula que "já em 1894, a legislação urbanística fazia eco ao entendimento de que o espaço público das ruas e avenidas deveria ser o espaço do deslocamento por excelência, tornando-o lei”.

329 Mais informações sobre este parecer da Comissão de Constituição, Justiça e Legislação Participativa pode ser visto em: http://camaramunicipalsp.qaplaweb.com.br/iah/fulltext/parecer/JUSTS0445-2009.pdf. Acesso em 26 de março de 2011.
} 
Agora é a hora de TODOS nós arregaçarmos as mangas e irmos atrás dos nossos direitos, ou o skate perde a cidade com maior número de praticantes do país. Se você não fizer nada agora, pode ser que, em pouco tempo, não possa mais tirar o skate de dentro da sua casa ("Proibição do skate em São Paulo”. Disponível em: http://triboskate.globo.com/whatsup.php?id=3352. Acesso em 27 de janeiro de 2011, grifo do autor).

Em pouquíssimo tempo o protesto virtual ganhou proporções significativas. Skatistas não só da cidade, como de várias partes do mundo, publicaram nas diversas redes sociais as suas respectivas indignações contra a possível proibição do skate nas ruas de São Paulo.

Aproveitando-se da polêmica, o programa "MTV Debate" 330, do canal de televisão MTV, resolveu fazer uma edição pautada no seguinte tema: "Dá para tirar o skate das ruas?". Para a discussão foram convidados seis participantes. A favor da prática do skate nas ruas estavam Alexandre Vianna (editor da Revista CemporcentoSkate); Daniel Baccaro (diretor do filme Vida Sobre Rodas) e Tiago Van Deursen (skatista e arquiteto). Os favoráveis ao projeto de lei do vereador Adolfo Quintas eram Marco Di Preto (assessor parlamentar na Câmara Municipal de São Paulo) ${ }^{331}$; Raphaela Galletti (moradora da Avenida Paulista) ${ }^{332}$ e João Maradei Jr. (primeiro gerente da Avenida Paulista) ${ }^{333}$. A mediação do debate ficou a cargo do apresentador Lobão.

Para aumentar ainda mais a polêmica, o programa iniciou-se com a seguinte questão: "existem algumas pistas espalhadas pela cidade, mas elas não são suficientes. Além disso, muitos skatistas preferem a interação com a cidade e desprezam as pistas. Afinal, dá para tirar o skate das ruas?’. Logo no começo do debate, os representantes do skate questionaram Marco Di Preto sobre o que motivou a elaboração do projeto de lei:

Tiago Van Deursen - Como surgiu isto, esta lei?

Marco Di Preto - O projeto existe desde 2007 basicamente, e foi muito influenciado por reportagens e ações que chegaram até nós, reclamando que a calçada, por ser um espaço de segurança do pedestre, estava sofrendo várias invasões, não só de skatistas como outras. E notamos que existe uma brecha, para

330 Este programa foi ao ar em 17 de agosto de 2010. O MTV Debate é um programa em que, a cada edição, temas polêmicos são debatidos por convidados especiais e especialistas.

331 Marco di Preto é também jornalista e ativista político e social.

332 Raphaela Galletti também é advogada e administradora de condomínios.

333 João Moradei Jr. também é advogado e diretor executivo da Associação AME Jardins. 
falar dos skatistas, que eles estavam... Entenda bem: não é questão de invadir. Eles estavam utilizando espaços que são de segurança do pedestre. O uso da calçada é estritamente de segurança do pedestre, mas ela pode ser usada para outros fins. O que a gente está querendo fazer é este debate.

Daniel Baccaro - Você não acha que o skatista faz parte deste pedestre?

Marco Di Preto - Logicamente. Com a própria questão da diversificação de gostos, da própria maneira de se expressar, eu entendo o skate como uma maneira de expressão e um esporte também. Existe um espaço, mas ele tem que ser debatido para a gente chegar em um bom termo.

Daniel Baccaro - Então eu acho que a palavra não seria proibição e sim organização. Porque uma lei tem que vir para uma inclusão social de todas as pessoas. A rua é pública, a calçada é pública. Então se o skate é proibido, a bicicleta também tem que ser proibida. Em 1988 foi proibido pelo Jânio Quadros e não deu certo. De repente, o ideal é a organização, onde todos possam usar, não só os pedestres, mas os skatistas também.

Após questionarem as motivações para a possível lei, o apresentador Lobão solicitou a participação do Major Benjamin, representante da Polícia Militar, que via telefone apresentou as implicações diante a prática do street skate na Avenida Paulista:

Major Benjamin - Na Avenida Paulista (...) a prática do skate, há dois fatores principais de perturbação do sossego público: o primeiro é a segurança dos moradores, de pessoas que circulam pelas calçadas da Avenida Paulista; e o outro é o sossego público, que foi mencionado há pouco em sua plataforma de debate, considerando os moradores que constantemente no período noturno, têm consultado a polícia e solicitado apoio com relação ao barulho dos shapes nas calçadas.

O debate prosseguiu marcado pelas diferentes visões e lógicas em torno dos usos vernaculares e apropriações dos espaços urbanos. Tal polêmica alimentou ainda mais a ira de muitos skatistas que, após ficarem cientes de que o vereador Adolfo Quintas se candidataria a deputado estadual nas eleições de 2010, fizeram campanha contra o mesmo pela Internet.

Tiago Lobo, que deixou o cargo de Coordenador de Esportes Radicais para também se candidatar a deputado estadual na mesma eleição ${ }^{334}$, expôs da seguinte forma sua opinião acerca dessa proibição do skate:

334 Tiago Lobo foi candidato a deputado estadual pelo PSDB. 
Quando surgiu o problema neste ano, intercedemos na hora, pois não deixaríamos que a prática do skate voltasse a ser proibida, como na época do Jânio. Andar de skate não é crime. (...) Sobre o projeto de lei, na hora em que soubemos de sua apresentação na Câmara, intercedemos. Conseguimos convencer o vereador a arquivar esta insanidade ("Skate na plataforma. Entrevista com Tiago Lobo". Disponível em: http://cemporcentoskate.uol.com.br/fiksperto.php?id=5570. Acesso em 20 de janeiro de 2011).

Também contrário à proibição, Walter Feldman ${ }^{335}$ publicou um texto em seu site em defesa dos skatistas. Para ele, mais importante que proibir a prática do street skate é regulamentá-la e também, oferecer mais espaços "próprios", como as pistas de skate:

Leis de boa convivência serão sempre bem-vindas numa cidade tumultuada como São Paulo. Mas cuidado, muito cuidado com o extremo rigor que não leva a nada e com a busca de culpados fáceis para nossos velhos desacertos urbanos. Há muita diferença entre proibir teoricamente de cima para baixo e buscar acordos razoáveis com a realidade. Uma coisa é vetar pura e simplesmente a prática de skate em lugares tradicionais, onde os problemas são eventuais e mínimos, e outra, muito diferente, estabelecer algumas regras, desde que sejam razoáveis e compatíveis. (...) Nada contra uma certa ordenação na prática do skate, mas nossa preocupação maior deve ser a de pensar novos espaços, promover eventos e torneios. Que essa meninada bem que merece ser, na vida e nas pistas, radicalmente feliz. E é disso que São Paulo precisa ("Em defesa de uma tribo do bem". Disponível em: http://walterfeldman.com.br/materia/opiniao/75/Em-defesa-de-uma-tribodo-bem.html. Acesso em 20 de janeiro de 2011).

Diante dos inúmeros protestos e posicionamentos contrários, Adolfo Quintas resolveu recuar com o projeto de lei que pretendia banir a prática do skate nas calçadas da cidade de São Paulo. O gabinete do vereador alegou que tinha havido uma precipitação em levar a proposta para votação ${ }^{336}$, e que o objetivo não era a proibição, mas ao contrário, apenas a promoção de um debate em torno das apropriações dos espaços urbanos a partir de certas práticas.

\footnotetext{
335 Walter Feldman, quando publicou o referido texto, também estava afastado de seu cargo de secretário de esportes do município para concorrer ao cargo de deputado federal pelo PSDB.

336 Vide: "Skatistas não devem perder espaços em SP". Disponível em: http://www1.folha.uol.com.br/folhateen/780010-skatistas-nao-devem-perder-espacos-em-sp.shtml. Acesso em 20 de janeiro de 2011.
} 
Após todas as polêmicas, os streeteiros ainda continuam indo à Avenida Paulista. E na procura por picos pela cidade vale de tudo: enfrentar seguranças, fugir de policiais, esquivar-se de assaltantes, dialogar com moradores, protestar contra vereadores, enfim, o streeteiro tem que ter, conforme Alexandre "Nicolau" me disse certa vez, a "malícia das ruas", isto é, tem que "saber lidar com as diversas situações que acontecem no cotidiano".

\title{
O skatista, o cidadão, o citadino
}

\begin{abstract}
O skatista sempre vai ser meio rebelde. Hoje sou pai, casado, tenho três filhas e mesmo assim, se estou fazendo manobra num corrimão tenho que sair correndo se chega um segurança. É uma coisa muito louca. Mas isso, no meio do skate, não faz muita diferença ("Palavra de Mestre: entrevista com Bob Burnquist". Revista World Tennis, n.71, 2009, 25, grifos meus).
\end{abstract}

Bob Burnquist, hoje com 34 anos, é um dos skatistas mais importantes da atualidade. Filho de pai norte-americano e mãe brasileira, começou a carreira ainda na década de 1980, em uma extinta pista chamada Ultra Skatepark, no bairro de Moema. Seguindo a tendência da época, destacou-se primeiramente em um half pipe. Porém, já no começo da década de 1990, com a extinção das inúmeras pistas da cidade de São Paulo, viu-se obrigado a ir para as ruas, praticar o street skate. Os anos se passaram, novas pistas surgiram e Bob retomou a prática na modalidade vertical ${ }^{337}$. E foi a partir da mesma que ele sagrou-se campeão de muitos eventos, recebendo consideráveis prêmios e sendo capa de diversas revistas ${ }^{338}$. Além disso, Bob Burnquist é um dos poucos praticantes do big air, modalidade praticada em uma mega rampa ${ }^{339}$. Todas essas habilidades propiciaram a esse skatista tornar-se um típico overall, dominando vários tipos de "terrenos"; logo, o respeito conquistado possibilitou-lhe ganhos, patrocínios e fama.

Mesmo sendo especialista em modalidades como vertical e big air, Bob Burnquist não deixa de lado a prática do skate nas ruas. Embora a faça com pouca regularidade, é justamente no momento em que se aventura no universo do street skate que toda sua

\footnotetext{
337 Conforme já apontado anteriormente, a modalidade vertical é praticada em um half pipe.

338 Bob Burnquist despontou no cenário do skate a partir de sua vitória em uma competição chamada Slam City Jam, realizada em 1995, no Canadá. Dessa data para cá, venceu inúmeros campeonatos em nível mundial; foi eleito "Skate of the Year" pela Thrasher Magazine em 1997; tornou-se personagem de jogos de videogame; licenciou seu nome para várias marcas, além de outros feitos. Para mais informações sobre este skatista, vide: http://www.bobburnquist.com.

339 Sobre tal prática, vide Anexo A.
} 
imagem construída se altera: de um ícone do esporte ela passa a um "vândalo" de equipamentos urbanos. Em função disso, como o próprio Bob apontou no trecho da entrevista citada, em algumas situações ele tem "que sair correndo" de seguranças.

Nesse sentido, por meio dessa e de outras situações, percebe-se que a prática do skate é vivida com certa ambigüidade. Se por um lado alguns agentes a tratam como socialmente aceita, sendo o skate um tipo de esporte "radical" voltado sobretudo para a juventude, por outro, toda a visibilidade é ocultada por conta dos dissabores oriundos da prática em locais tidos como "inapropriados" ${ }^{340}$, sejam eles privados ou públicos.

Conforme já apresentado, em certos momentos da história houve uma tentativa de proibição do skate nas ruas. Em 1988 o então prefeito Jânio Quadros alegava que a prática atrapalhava a circulação de pedestres, além de trazer riscos não só para os skatistas, como também para outras pessoas. Mais de vinte anos após o ocorrido, novamente a proibição foi tentada na cidade de São Paulo, desta vez, por parte do vereador Adolfo Quintas. Com justificativas próximas à de Jânio Quadros, o referido vereador também ressaltava que a prática do street skate traz sérios danos aos patrimônios públicos e aos espaços urbanos, os quais são degradados em virtude das manobras realizadas. Contudo, em contraponto a esse e outros agentes, os skatistas encontraram uma série de mediadores também ligados ao poder público - como Tiago Lobo, Arthur Soares e Walter Feldman - que defenderam não a mera proibição da prática, mas o direito à mesma, mesmo que isso implicasse na tentativa de sua regulamentação.

Em síntese, nota-se que o Circuito Sampa Skate, apresentado no Capítulo I, tenta de certa forma lidar com as ambigüidades inicialmente apresentadas, onde de um lado está envolvido o exercício de uma prática esportiva, e de outro, as implicações em torno dos usos das ruas. Com efeito, os organizadores do circuito, com vistas a disciplinar e

\footnotetext{
340 O site oficial do evento Oi Mega Rampa 2009 traz um exemplo da visibilidade e dos investimentos feitos à prática do skate, tida como socialmente aceita: "as arquibancadas do Sambódromo do Anhembi ficaram lotadas no final de semana com mais de 16 mil pessoas. A Rede Globo e o canal SporTV transmitiram as disputas ao vivo e veicularam reportagens em seus telejornais um total de mais de 11 horas de divulgação para o skate. As TVs de Internet mostraram 51 vídeos da Oi Mega Rampa, foram cerca de 130 matérias em jornais e revistas, e quase 300 artigos postados na Internet, gerando um retorno de mídia de aproximadamente R\$ 30 milhões" (Disponível em http://www.oimegarampa.com.br/2009/html/imprensa/. Acesso em 26 de junho de 2010). Por outro lado, em uma matéria intitulada "Esporte ou vandalismo?", os skatistas são retratados como "vândalos": "querem andar de skate na rua? Tudo bem! O problema não está no esporte ou no equipamento, mas no uso que certas 'cabeças ocas' ou mal-intencionadas fazem deles, em locais e situações impróprias. Os que praticam não merecem ser chamado de esporte radical: é vandalismo!" (Disponível em http://www.novaimprensa.inf.br/passadas/467/opinioes.html. Acesso em 26 de junho de 2010, grifos meus).
} 
regulamentar a prática do street skate, criaram um formato de evento pautado na ampliação da cidadania $^{341}$, sendo que essa, de acordo com suas visões, promoveria a inclusão social. Desse modo, os skatistas possuiriam seus direitos: a construção de várias pistas públicas em diversos pontos da cidade, além do apoio de agentes do poder público para a organização de eventos. E ainda, seus deveres: se há pistas de skate e se os campeonatos acontecem nelas, os skatistas deveriam praticar o skate somente nos espaços apropriados, evitando as ruas.

O site da Skate Contest deixa bem claro um dos sentidos atribuídos à inclusão social que a mesma tenta promover, em parceria com a Secretaria de Esportes, a partir da realização do Circuito Sampa Skate: por meio de uma série de eventos são criadas ações “(...) que contribua[m] para afastar o jovem da ociosidade, das drogas e conseqüentemente do crime" ${ }^{342}$. O Circuito Sampa Skate, através dessa perspectiva, levaria os participantes a manter a "mente ocupada" ${ }^{343}$; portanto, eles são influenciados a levar a sério a competição ao longo de todo o ano, devendo buscar um desempenho satisfatório tendo em vista os benefícios que podem ser conquistados mediante a uma boa colocação no ranking final.

De fato, os skatistas se sentem motivados a participar dessa dinâmica promovida pelos organizadores. Entretanto, como o circuito é itinerante, à proporção que participam de sua realização, eles circulam pela cidade, criam vínculos e atualizam as informações de interesses mútuos com outros participantes. Em meio a tudo isso muitos deles, principalmente os mais novos praticantes, também são socializados no universo da modalidade street skate, onde aprendem novos códigos e participam de certas experiências comuns aos outros que ali estão. Dessa forma, os skatistas produzem um deslocamento simbólico nos propósitos do circuito: para eles, a inclusão social por meio da prática do skate tem mais a ver com um alargamento da sociabilidade do que com a disputa esportiva propriamente dita. Isso fica evidente durante a realização dos eventos.

Conforme observado etnograficamente, há momentos onde se instauram, com maior ou menor intensidade, a rivalidade, a competitividade, a solidariedade, a reciprocidade, a jocosidade. Por meio de constantes idas a campo e à medida que se ampliava minha rede de relações, percebi que embora exista a competição, para vários

\footnotetext{
341 Tal representação, bem como o formato estabelecido para a realização do Circuito Sampa Skate foiram discutidos no primeiro capítulo.

${ }^{342}$ Disponível em http://skatecontest.com.br/. Acesso em 20 de janeiro de 2010.

${ }^{343}$ A utilização dessa conhecida expressão é feita aqui com base nas falas de interlocutores como Márcio Tanabe e Everton Canuto.
} 
skatistas a mesma é o que menos importa. Em virtude disso, muitos não se intitulam "atletas", e não fazem questão de treinar ou fazer alguma preparação física, pois o mais importante, segundo eles, é "se divertir".

Cada etapa do circuito, realizada durante um final de semana, tem hora para começar, mas não para terminar. Com isso os skatistas, de um modo geral, passam mais tempo com aqueles que são considerados "amigos" que, de fato, andando de skate. Em certos instantes a competitividade é diluída (embora não seja extinta), dando margens ao estabelecimento de relações e associações com vários outros participantes do evento que são, ao mesmo tempo, competidores e espectadores.

Nos campeonatos os skatistas criam formas de sociabilidade que propiciam arranjos em suas associações ${ }^{344}$, que os deixam "todos juntos e misturados" 345 . De acordo com o interesse da situação os mesmos ligam-se ou desligam-se de novos relacionamentos, que são efêmeros. Na presença de competidores de várias localidades, os contatos são ampliados. Geralmente mantidos pela Internet, através deles os skatistas marcam encontros para andar de skate juntos, embora não somente em pistas e em regiões periféricas, mas também nas ruas e em regiões centrais da cidade, em locais como Vale do Anhangabaú, Parque do Ibirapuera, Avenida Paulista, dentre outros.

Se para o poder público a cidadania se aproxima, de certo modo, do conceito de civilidade, para os skatistas - ou, para ser mais específico, para os streeteiros - a condição de cidadão está mais relacionada à sociabilidade e, portanto, à de citadino. Como pôde ser visto no decorrer da etnografia, há ainda uma espécie de repulsa a uma sociabilidade confinada a espaços que dispõem de certas regras, como as pistas, em prol da valorização de seu alargamento por toda a cidade. Sendo assim, sujeitar esses citadinos às competições com normas precisas, sendo muitas delas morais, e também, confiná-los somente em espaços construídos especialmente para a prática esportiva, não detém os devires do universo da modalidade street skate.

Com o andamento do trabalho de campo foi possível observar que a prática do street skate não é facilmente identificável somente com pontos definidos da cidade. Ela pode ser vista em muitos lugares, não definidos de antemão. Dessa maneira, ao circular pelo meio urbano tendo em vista, por meio do olhar skatista, a procura de lugares skatáveis, a cidade é ordenada a partir das experiências diversificadas dos skatistas.

\footnotetext{
344 Os arranjos criados pelos skatistas, de certa maneira, correspondem a "uma forma específica de se expor, estabelecer laços, marcar diferenças, fazer escolhas, colocar-se, enfim, na paisagem urbana diante dos outros e em relação a eles" (Magnani, 2007, 253).

${ }^{345}$ Essa frase foi dita por diferentes interlocutores ao longo do trabalho de campo.
} 
Ao longo desta pesquisa compreende-se também como os skatistas constroem redes mais amplas de relações, por meio da constituição de sociabilidades alargadas 346 (Agier, 1999), onde "se estabelecem níveis intermediários de vida social, situados entre o mundo doméstico de tais citadinos e as instituições ou macroestruturas mais abrangentes" (Frúgoli Jr., 2007, 50). Através de uma série de mediações sociais os skatistas tornam-se mais urbanos; logo, partindo de Agier (1998, 61), as formas de sociabilidade criadas em torno da prática do street skate se configuram enquanto mediadoras entre estes citadinos e a cidade.

Com base nas aproximações e distanciamentos dos habitantes da cidade, Isaac Joseph $(2005,96)$ salienta que o citadino não se reduz à figura do transeunte, assim como não coincide obrigatoriamente com a do cidadão. Partindo do ponto de vista desse autor e levando em conta o caráter relacional e situacional apresentado em torno do universo do street skate, conclui-se que as práticas citadinas incorporam ou englobam as práticas de cidadania no contexto urbano. Conforme se evidenciou na etnografia, os skatistas citadinos se beneficiam das alternativas fornecidas pelo poder público (como os campeonatos e as pistas) e se posicionam politicamente diante suas demandas. Todavia, por mais que participem das competições e pratiquem em espaços "apropriados", eles não deixam de ir para as ruas, onde para muitos se anda de skate de "verdade", pois são nelas em que podem fazer uma parte de seus "trabalhos", como a captação de imagens para a mídia especializada (tal como apresentado no Capítulo III), e também, onde se vivencia aquilo que é apontado como primordial no skate, ou seja, a "diversão" em companhia de outros (tal como apresentado no Capítulo II).

Em palavras conclusivas é importante ressaltar que por meio desta pesquisa tentou-se pensar as formas de apropriação dos espaços urbanos através da prática do skate, fazendo com que a cidade não fosse lida mediante as teorizações apriorísticas que a tratam como uma "coisa", mas através do que os streeteiros chamam de olhar skatista. Desse modo, inspirando-me em Agier (2011, 17), em vez de demonstrar "o que é a cidade" tratei em evidenciar como os citadinos "fazem a cidade", buscando atingir assim "significados mais abrangentes da cidade, paradoxalmente mais otimistas que os diagnósticos de urbanistas e outros intelectuais europeus, que tendem a enfatizar a 'nãocidade', os 'não-lugares' ou o 'pós-urbano' (Agier, 1999, 14-15). Portanto, os skatistas,

\footnotetext{
346 Estes domínios das sociabilidades alargadas, que se baseiam nas dinâmicas das redes, de uma forma ampliada levaria, em última instância e numa perspectiva totalizante, “à própria compreensão da cidade enquanto 'rede das redes' (como já aventara Hannerz), mesmo que isso se trate, admite o autor, de um horizonte metafórico, impossível de uma reconstituição antropológica” (Frúgoli Jr., 2007, 50-51).
} 
seja em suas condições de cidadãos ou citadinos, buscam conquistar a cidade por meio de suas múltiplas práticas, discursos, relações e experiências cotidianas vividas em situação. 


\section{Referências bibliográficas}

AGIER, Michel. "Lugares e redes: as mediações da cultura urbana". In: NIEMEYER, A.M. \& GODOI, E.P. (orgs.). Além dos Territórios: para um diálogo entre a etnologia indígena, os estudos rurais e os estudos urbanos. Campinas, Mercado das Letras, 1998, p.41-63.

. L'invention de la ville. Paris, Ed. des Archives Contemporaines, 1999.

. "Distúrbios identitários em tempos de globalização". Revista Mana, Rio de Janeiro, vol. 7, $\mathrm{n}^{\circ}$ 2, 2001, p.7-33.

Antropologia da cidade: lugares, situações, movimentos. São Paulo, Editora Terceiro Nome, 2011.

AGUIAR, Reinaldo Olécio. "A sociabilidade esportiva das igrejas Renascer em Cristo e Bola de Neve". In: TOLEDO, Luiz Henrique de; COSTA, Carlos Eduardo (orgs.). Visão de jogo: antropologia das práticas esportivas. São Paulo, Editora Terceiro Nome, 2009, p. 45-74.

AGUIAR, Tiago Cambará. $O$ bom, o mau e o feio - o design gráfico da indústria do skate. Dissertação de mestrado em Design, PUC-Rio, 2008.

ARCHETTI, Eduardo. Masculinidades. Fútbol, tango y pólo em la Argentina. Buenos Aires, Editorial Antropofagia, 2003.

BARNES, John A. "Redes sociais e processo político". In: FELDMAN-BIANCO, Bela (org.). Antropologia das sociedades contemporâneas - métodos. São Paulo, Editora UNESP, 2010 [1969], p. 171-204.

BASTOS, Billy Graeff. Estilo de vida e trajetórias sociais de skatistas: da "vizinhança" ao "corre". Dissertação de mestrado em Ciências do Movimento Humano, UFRGS, 2006.

"O segredo do sucesso: apontamentos sobre a trajetória social de skatistas profissionais". Revista Movimento. V.15, n 3, 2009, p.163-186.

BRANDÃO, Leonardo. Corpos deslizantes, corpos desviantes: a prática do skate e suas representações no espaço urbano. Dissertação de mestrado em História. Universidade Federal da Grande Dourados, UFGD, 2006.

"Entre a marginalização e a esportivização: elementos para uma história da juventude skatista no Brasil". Recorde: Revista de História de Esporte. V.1, ${ }^{\circ} 2$, dezembro de 2008.

"História e esporte: leituras do corpo no filme Dogtown and Z-Boys". Revista História em Reflexão. Dourados, UFGD, vol.03, n 5, jan./jun. 2009. 
" A introdução dos esportes californianos no Brasil: apontamentos para o início de uma discussão". Revista Fronteiras. Dourados-MS, v.11, n 19, jan./jun.2009, p.327348 .

BRITTO, Eduardo. A onda dura: três décadas de skate no Brasil. São Paulo, Parada Inglesa, 2000.

BROOKE, Michel. The concrete wave: the history of skateboarding. EUA, Warwick House Publishing, 1999.

COSTA, Carlos Eduardo. "Torneios universitários: disputas e sociabilidade nas práticas estudantis". In: TOLEDO, Luiz Henrique de; COSTA, Carlos Eduardo (orgs.). Visão de jogo: antropologia das práticas esportivas. São Paulo, Editora Terceiro Nome, 2009, p. $17-44$.

COSTA, Maria Regina de Menezes. Aventura e risco no skateboard street: um estudo do imaginário de jovens skatistas. Dissertação de mestrado em Educação Física, Universidade Gama Filho, 2004.

CUIN, C.; GRESLE, F. História da sociologia. São Paulo, Ensaio (Cadernos Ensaio Pequeno Formato, 10), 1994.

DAMATTA, Roberto (org.). Universo do futebol: esporte e sociedade brasileira. Rio de Janeiro, Pinakotheke, 1982.

DAMO, Arlei. Do dom à profissão: a formação de futebolistas no Brasil e na França. São Paulo, Aderaldo \& Rothschild Ed/ANPOCS, 2007.

DE CERTEAU, Michel. A invenção do cotidiano: artes de fazer. Petrópolis, Editora Vozes, $2009,16^{\circ}$ ed.

ECKERT, Cornelia. "Cidade e política: nas trilhas de uma antropologia na e da cidade no Brasil". In: DUARTE, Luiz Fernando Dias (coord. de área); MARTINS, Carlos Benedito (coord. geral). Horizontes das Ciências Sociais no Brasil: Antropologia. São Paulo, ANPOCS, 2010, p.155-196.

FELDMAN-BIANCO, Bela (org.). "Introdução". Antropologia das sociedades contemporâneas - métodos. São Paulo, Editora UNESP, 2010, p. 19-56.

FIGUEIRA, Márcia Luiza Machado. "Gênero e práticas corporais no site Skate para Meninas". In: Seminário Corpo, Gênero e Sexualidade, 3., 2007, Porto Alegre. Discutindo práticas educativas. Porto Alegre: UFRGS e FURG, 2007.

Skate para meninas: modos de se fazer ver em um esporte em construção. Tese de doutorado em Ciências do Movimento Humano, UFGRS, 2008.

FIGUEIRA, Márcia Luiza Machado; GOELLNER, Silvana Vilodre. "Skate e mulheres no Brasil: fragmentos de um esporte em construção". Revista Brasileira de Ciências do Esporte. Campinas, vol.30, n 3, p.95-110, maio de 2009. 
FORTES, Rafael. "Os anos 80, a juventude e os esportes radicais". In: DEL PRIORE, Mary; MELO, Victor Andrade (orgs.). História do Esporte no Brasil. São Paulo, Editora UNESP, 2009, p. 417-451.

FREHSE, Fraya. "Usos da rua". In: FORTUNA, Carlos; LEITE, Rogério Proença (orgs). Plural de cidade: novos léxicos urbanos. Coimbra, Almedina, 2009, p. 151-170.

FREHSE, Fraya; LEITE, Rogério Proença. "Espaço urbano no Brasil”. In: MARTINS, Heloisa Helena T. de Souza (coord. de área); MARTINS, Carlos Benedito (coord. geral). Horizontes das Ciências Sociais no Brasil: Sociologia. São Paulo, ANPOCS, 2010, p. 203-252.

FRÚGOLI JR, Heitor. São Paulo: espaços públicos e interação social. São Paulo, Ed. Marco Zero, 1995.

. "A Avenida Paulista como pólo de expressões públicas e coletivas na cidade de São Paulo. NPP - Núcleo de Pesquisas e Publicações. São Paulo, EAESP, FGV, 1996 (Relatório de pesquisa).

Centralidade em São Paulo: trajetórias, conflitos e negociações na metrópole. São Paulo, Cortez/Edusp, 2000.

" "O urbano em questão na antropologia: interfaces com a sociologia." Revista de Antropologia, São Paulo, v. 48, $\mathrm{n}^{\circ}$ 1, 2005, p. 133-165.

Sociabilidade urbana. Rio de Janeiro, Jorge Zahar Editor, 2007.

GASTALDO, Édison. "O complô da torcida: futebol e performance masculina em bares". Revista Horizontes Antropológicos. Porto Alegre, ano 11, $\mathrm{n}^{\circ} 24$, jul./dez. 2005, p. 107-123.

GIGLIO, Sérgio Settani; SPAGGIARI, Enrico. "A produção das ciências humanas sobre futebol no Brasil: um panorama (1990-2009)". Revista de História. São Paulo, Departamento de História da FFLCH/USP, nº 163, jul./dez. 2010, p. 293-352.

GUEDES, Simoni Lahud. O futebol brasileiro: instituição zero. Dissertação de mestrado em Antropologia. Universidade Federal do Rio de Janeiro, UFRJ, 1977.

"Esporte, lazer e sociabilidade". In: DUARTE, Luiz Fernando Dias (coord. de área); MARTINS, Carlos Benedito (coord. geral). Horizontes das Ciências Sociais no Brasil: Antropologia. São Paulo, ANPOCS, 2010, p. 431-456.

HANNERZ, Ulf. Exploring the City: Inquiries toward an Urban Anthropology. Nova York, Columbia University Press, 1980.

HIKIJI, Rose Satiko Gitirana. A música e o risco. São Paulo, EDUSP, 2006.

HONORATO, Tony. A tribo skatista e a instituição escolar: o poder escolar em uma perspectiva sociológica. Dissertação de mestrado em Educação, UNIMEP, 2005. 
JOSEPH, Isaac. La ville sans qualités. Paris, Éditions de l'Aube, 1998.

"Paisagens urbanas, coisas públicas". Cadernos CRH. Salvador, n 30/31, 1999, p. 11-40. Tradução de Regina Martins da Matta.

"A respeito do bom uso da Escola de Chicago". In: VALLADARES, Lícia do Prado (org.). A Escola de Chicago: impacto de uma tradição no Brasil e na França. Belo Horizonte/Rio de Janeiro, Ed. UFMG/IUPERJ, 2005 [1998], p. 93-128.

LATOUR, Bruno. Jamais fomos modernos: ensaio de antropologia simétrica. São Paulo, Ed. 34, 2008.

LE BRETON, David. Condutas de risco: dos jogos de morte ao jogo de viver. Campinas, Autores Associados, 2009.

LEITE, Rogério Proença. "Margens do dissenso: espaço, poder e enobrecimento urbano". In: FRÚGOLI JR., Heitor; ANDRADE, Luciana Teixeira de; PEIXOTO, Fernanda Áreas (orgs.). As cidades e seus agentes: práticas e representações. Belo Horizonte, PUC Minas/Edusp, 2006, p. 23-44.

MACHADO, Giancarlo Marques C. Todos juntos e misturados: um estudo sobre a formação das redes de relações entre skatistas em campeonatos de skate. Trabalho de conclusão de curso em Ciências Sociais. Universidade Estadual de Montes Claros, Unimontes, 2008.

MAGNANI, José Guilherme C. “Tribos urbanas: metáfora ou categoria?”. Cadernos de Campo. Departamento de Antropologia, FFLCH/USP, São Paulo, ano 2, n 2, 1992.

Rua, símbolo e suporte da experiência urbana. Disponível em http://www.n-au.org/ruasimboloesuporte.html. Acesso em 20 de dezembro de 2009.

. "De perto e de dentro: notas para uma etnografia urbana". Revista Brasileira de Ciências Sociais, São Paulo, vol.17, n 49, 2002, p. 11-29.

. "Introdução - circuitos de jovens". In: MAGNANI, José Guilherme C.; SOUZA, Bruna Mantese (orgs.). Jovens na metrópole: etnografias de circuitos de lazer, encontro e sociabilidade. São Paulo, Editora Terceiro Nome, 2007, p. 15-22.

"Etnografia urbana". In: FORTUNA, Carlos; LEITE, Rogério Proença (orgs.). Plural de cidade: novos léxicos urbanos. Coimbra, Almedina, 2009, p. 101-113.

MARCUS, George E. Ethnography in/of the world system: the emergence of multi-sited ethnography. Annual Review of Anthropology, v. 24, 1995, p. 95-117. 1998.

Ethonography through thick and thin. Priceton, Princeton University Press,

MARQUES, Rafael Adriano. "O que é que o Ibirapuera tem? Le Parkour e 'esportes radicais' no parque". Ponto Urbe: Revista do Núcleo de Antropologia Urbana da USP. Ano 2, versão 3.0, julho de 2008. 
MAYER, Adrian. "A importância dos 'quase-grupos' no estudo das sociedades complexas". In: FELDMAN-BIANCO, Bela (org.). Antropologia das sociedades contemporâneas - métodos. São Paulo, Editora UNESP, 2010 [1966], p. 139-160.

MENEGUELLO, Cristina. "Espaços e vazios urbanos". In: FORTUNA, Carlos; LEITE, Rogério Proença (orgs.). Plural de cidade: novos léxicos urbanos. Coimbra, Almedina, 2009, p.127-138.

MITCHELL, J. Clyde. "A dança kalela: aspectos das relações sociais entre africanos urbanizados na Rodésia do Norte”. In: FELDMAN-BIANCO, Bela (org.). Antropologia das sociedades contemporâneas - métodos. São Paulo, Editora UNESP, 2010 [1956], p. 365-436.

OLIC, Mauricio Bacic. Arte, Cotidiano e Juventude: a "reinvenção" do espaço público por parte dos jovens skatistas. Disponível em http://orbita.starmedia.com/outraspalavras/art09mbo.htm. Acesso em 29 de junho de 2010.

Entre o liso e o estriado: skatistas na metrópole. Dissertação de Mestrado em Ciências Sociais, PUC-SP, 2010.

OLIVEIRA, Marcelo Nahuz de. "Avenida Paulista: a produção de uma paisagem de poder". In: ARANTES, Antonio A. (org.). O espaço da diferença. Campinas, Papirus, 2000, p. 208-255.

PARK, Robert E. "A cidade: sugestões para a investigação do comportamento humano no meio urbano". In: VELHO, Otávio G. (org). O fenômeno urbano. Rio de Janeiro, Guanabara, 1987 [1916].

PERALVA, Angelina. Violência e democracia: o paradoxo brasileiro. São Paulo, Paz e Terra, 2000.

PEREIRA, Alexandre Barbosa. De rolê pela cidade: os pixadores em São Paulo. Dissertação de Mestrado em Antropologia Social. Faculdade de Filosofia, Letras e Ciências Humanas da USP, São Paulo, 2005.

. "Aprendendo a ser jovem: a escola como espaço de sociabilidade juvenil". In: XIII Congresso Brasileiro de Sociologia, 2007, Recife/PE.

"Pichando a cidade: apropriações 'impróprias' do espaço urbano". In: MAGNANI, José Guilherme C.; SOUZA, Bruna Mantese (orgs.). Jovens na metrópole: etnografias de circuitos de lazer, encontro e sociabilidade. São Paulo, Editora Terceiro Nome, 2007, p. 225-246.

- "As relações de ludicidade e jocosidade no contexto escolar: relatos etnográficos". In: VIII Reunión de Antropología del Mercosur (RAM), 2009, Buenos Aires. 
POCIELLO, Christian. "Os desafios da leveza: as práticas corporais em mutação". In: SANT'ANNA, Denise Bernuzzi de (org.). Políticas do corpo: elementos para uma história das práticas corporais. São Paulo, Editora Estação Liberdade, 1995.

RADCLIFFE-BROWN, A.R. Estrutura e função nas sociedades primitivas. Lisboa, Edições 70, 1989.

RECUERO, Raquel. "Webrings: as redes de sociabilidade e os weblogs". Sessões do imaginário, Porto Alegre, v. 11, 2004.

SANT'ANNA, Denise Bernuzzi de. "Entre o corpo e a técnica: antigas e novas concepções". Revista Motrivivência, n 15, agosto de 2000.

SIERRA, Vânia Morales. "Crise das representações e o déficit da urbanidade". Achegas - Revista de Ciências Políticas. No 24. Julho/Agosto 2005. Disponível em http://www.achegas.net/numero/vinteequatro/vania_sierra_24.htm. Acesso em $01 \mathrm{de}$ junho de 2010.

SIERRA, Vânia Morales; MESQUITA, Wania Amélia Belchior. "A democracia no espaço: uma revisão dos conceitos de Isaac Joseph". Os Urbanitas: Revista de Antropologia Urbana. V.6, $\mathrm{n}^{\circ}$ 9, outubro de 2009. Disponível em: http://www.aguaforte.com/osurbanitas9/Sierra_\&_Mesquita_urbanitas-09-2009.html.

Acesso em 20 de janeiro de 2011.

SILVANO, Filomena. Antropologia do espaço. Lisboa, Assírio \& Alvim, 2010.

SIMMEL, Georg. "O estrangeiro". In: MORAES, Evaristo (org.). Sociologia: Simmel, São Paulo, Ática, 1983 [1908].

"A metrópole e a vida mental". In: Velho, Otávio (org.). O fenômeno urbano. Rio de Janeiro, Zahar, 1987.

SPAGGIARI, Enrico. Tem que ter categoria: construção do saber futebolístico. Dissertação de Mestrado em Antropologia Social. Faculdade de Filosofia, Letras e Ciências Humanas da USP, São Paulo, 2009.

STAHLBERG, Lara Tejada. "Jogando em vários campos: torcedoras, futebol e gênero". In: TOLEDO, Luiz Henrique de; COSTA, Carlos Eduardo. Visão de jogo: antropologia das práticas esportivas. São Paulo, Editora Terceiro Nome, 2009, p. 141-166.

TOLEDO, Luiz Henrique de. Lógicas no futebol. São Paulo, Hucitec/FAPESP, 2002.

. "Corporalidade e festa na metrópole". In: MAGNANI, José Guilherme C.; SOUZA, Bruna Mantese de (orgs.). Jovens na metrópole: etnografias de circuitos de lazer, encontro e sociabilidade. São Paulo, Editora Terceiro Nome, 2007, p. 255-266.

TOLEDO, Luiz Henrique de; COSTA, Carlos Eduardo (orgs.). Visão de jogo: antropologia das práticas esportivas. São Paulo, Editora Terceiro Nome, 2009. 
UVINHA, Ricardo Ricci. Lazer na adolescência: uma análise sobre os skatistas do $A B C$ paulista. Dissertação de mestrado em Educação Física. Faculdade de Educação Física da UNICAMP, 1997.

VELHO, Gilberto. Projeto e metamorfose: antropologia das sociedades complexas. Rio de Janeiro, Jorge Zahar, 2003.

Individualismo e cultura: notas para uma antropologia da sociedade contemporânea. Rio de Janeiro, Jorge Zahar, 2004, 3. ed.

WAGNER, Roy. "Are there social groups in the New Guinea Highlands?". In LEAF, M.J. (org.). Frontiers of anthropology: na introduction to anthropological thinking. New York, D. Van Nostrand Company, 1974, p. 95-122.

WAIZBORT, Leopoldo. As aventuras de Georg Simmel. São Paulo, Ed. 34, 2000.

WIRTH, Louis. "The Ghetto". In: HANNERZ, Ulf. Exploring the City: Inquiries toward an Urban Anthropology. Nova York, Columbia University Press, 1980 [1928].

ZALUAR, Alba. Cidadãos não vão ao paraíso. Campinas, Ed. UNICAMP, 1994.

ZUKIN, Sharon. "Paisagens urbanas pós-modernas: mapeando cultura e poder". In: ARANTES, Antonio A. (org.). O espaço da diferença. Campinas, Papirus, 2000, p. 80103.

\section{Materiais de imprensa}

ARAKAKI, Sidney. "Como é trabalhar nos bastidores dos eventos". Blog Skataholic, São Paulo. Disponível em http://www.skataholic.com.br/2009/08/como-e-trabalhar-nosbastidores-dos.html. Acesso em 30 de maio de 2010.

ARAÚJO, Uiara. "Skate: Paulista, Ibirapuera e Anhangabaú são bons 'picos de rua"". Veja São Paulo. Disponível em: http://vejasp.abril.com.br/noticias/skate-paulistaibirapuera-anhangabau-sao-bons-picos-de-rua. Acesso em 25 de janeiro de 2011.

BRITO, Paulo; CALADO, Luiz. "Andar de skate não é crime”. Revista Yeah!, São Paulo, n $^{\circ} 10$, ano II, 1988.

CÂMARA MUNICIPAL DE SÃO PAULO. Projetos apresentados na íntegra. Disponível em: http://www.camara.sp.gov.br/projintegrapre.asp?fProjetoLei=116\%2F09\&sTipoPrj=PL. Acesso em 19 de dezembro de 2009.

CONFEDERAÇÃO BRASILEIRA DE SKATE. "Dados do esporte". Site CBSK. Disponível em: http://www.cbsk.com.br/pags/dados.htm. Acesso em 22 de março de 2010. 
- "Regulamento". Site CBSK. Disponível em: http://www.cbsk.com.br/pags/regulamento.htm. Acesso em 12 de maio de 2011.

ET, Marcos. “Sk8 Overall: qual é a sua?”. Revista Tribo Skate, n 78, 2002.

FELDMAN, Walter. "Em defesa de uma tribo do bem". Disponível em: http://walterfeldman.com.br/materia/opiniao/75/Em-defesa-de-uma-tribo-do-bem.html. Acesso em 20 de janeiro de 2011.

FOLHA DE SÃO PAULO. "Jânio proíbe uso de skate em S. Paulo". Caderno Cidades, 25 de junho de 1988.

. "Ibirapuera veta esporte radical em marquise". Cotidiano. Disponível em: http://www1.folha.uol.com.br/folha/cotidiano/ult95u84672.shtml. Acesso em 21 de janeiro de 2011.

GABINETE VEREADOR ADOLFO QUINTAS. Justificativa Projeto de Lei 116/09. Disponível em: http://camaramunicipalsp.qaplaweb.com.br/iah/fulltext/justificativa/JPL0116-2009.pdf. Acesso em 27 de janeiro de 2011.

GONÇALVES, Adilson Luiz. "Esporte ou vandalismo?". Nova Imprensa Online. Disponível em: http://www.novaimprensa.inf.br/passadas/467/opinioes.html. Acesso em 26 de junho de 2010 .

GUIA DE PISTAS. Revista CemporcentoSkate. São Paulo, edição especial, 2006.

JORDY, Stela. "A escultura da aranha gigante". Blog Plasticamente. Disponível em: http://plasticamente.wordpress.com/2008/04/24/a-escultora-da-aranha-gigante/. Acesso em 20 de janeiro de 2011.

JORNAL DA TARDE. “Av. Paulista vira pista de skate”. 11 de julho de 2008. Disponível em http://txt.jt.com.br/editorias/2008/07/11/ger-1.94.4.20080711.25.1.xml. Acesso em 29 de maio de 2010.

MINOZZI, Felipe. "Proibição do skate em São Paulo". Site Tribo Skate. Disponível em: http://triboskate.globo.com/whatsup.php?id=3352. Acesso em 27 de janeiro de 2011.

MUG, Marcelo. “Avenida Paulista: o passeio nosso de cada dia”. Revista Tribo Skate, São Paulo, n 161 , março de 2009. $\overline{\text { de } 2011 .}$.

“"Sandro Sobral: sem discussão”. Revista Tribo Skate, São Paulo, n 183, janeiro

PABST, Maíra. “Eu nunca treinei um dia sequer', Bob Burnquist”. Site ESPN Brasil. Disponível em: http://espnbrasil.terra.com.br/skate/noticia/129391_EXCLUSIVO+EU+NUNCA+TREI NEI+UM+DIA+SEQUER+BOB+BURNQUIST. Acesso em 29 de janeiro de 2011. 
PIERANTONI, Roberto. “Oi Mega Rampa 2009 tem investimento de R\$ 5 milhões”. Oi Mega Rampa 2009, São Paulo. Disponível em http://www.oimegarampa.com.br/2009/html/imprensa/. Acesso em 19 de abril de 2010.

PRIETO, Douglas. "Diferentes terrenos, diferentes skatistas". Portal CemporcentoSkate. Disponível em: http://cemporcentoskate.uol.com.br/blogLer.php?categoria=9. Acesso em 25 de janeiro de 2011.

- "Ser do Centro". Portal CemporcentoSkate. Disponível em: http://cemporcentoskate.uol.com.br/blogLer.php?categoria=9. Acesso em 20 de janeiro de 2011.

. “A disputa da coroa”. Revista CemporcentoSkate, São Paulo, n. ${ }^{\circ}$ 156, 2011.

2011.

“As palavras malditas do skate”. Revista CemporcentoSkate, São Paulo, n. ํ 159,

QIX TV CONTEST. "Regulamento". Site Qix. Disponível em: http://www.qix.com.br/regulamento/. Acesso em 12 de maio de 2011.

REVISTA CEMPORCENTOSKATE. "Filosofia de vida: dividir a premiação". São Paulo, $\mathrm{n}^{\circ}$ 56, 2002.

__. "SP do skate". São Paulo, n 98, 2006.

. “Chão sagrado". São Paulo, n 138, 2009.

; "10 coisas que você deveria saber sobre o Vale do Anhangabaú". São Paulo, edição 12, ano 15, 2010.

. “Kelvin Hoefler: pronto para decolar”. São Paulo, edição 14, ano 15, 2010.

. "O skate cresce no Brasil”. São Paulo, edição 15, ano 15, 2010.

REVISTA TRIBO SKATE. “Encrewzilhada”. São Paulo, n 179, agosto de 2010.

REVISTA TRIP. "O salto do skate". Disponível em http://revistatrip.uol.com.br/revista/colunas/o-salto-do-skate.html. Acesso em 26 de junho de 2010.

REVISTA VEJA. “A onda de cimento”. São Paulo, n 1004, 2 de dezembro de 1987.

REVISTA WORLD TENNIS. "Palavra de mestre: entrevista com Bob Burnquist". $\mathrm{N}^{\circ}$ $71,2009$.

ROXO, Elisangela. "Skatistas não devem perder espaços em SP". Folha Online, São Paulo. Disponível em: http://www1.folha.uol.com.br/folhateen/780010-skatistas-naodevem-perder-espacos-em-sp.shtml. Acesso em 20 de janeiro de 2011. 
SARLI, Carlos. "Pista livre". Folha Online, São Paulo. Disponível em http://www1.folha.uol.com.br/folha/esporte/ult92u102808.shtml. Acesso em 30 de maio de 2011.

SAYAD, Mariana. "De marginal a queridinho". Revista Competir Sports Marketing, São Paulo, $\mathrm{n}^{\circ}$ 1, junho de 2010. Disponível em: http://www.competirsportsmarketing.com.br/materias/. Acesso em 26 de junho de 2010.

SKATEBOARD CONTEST. Sampa Skate. Disponível em http://skatecontest.com.br/. Acessos em 20 de janeiro e 30 de abril de 2010.

VIANNA, Alexandre. "Skate na plataforma: entrevista com Tiago Lobo". Portal CemporcentoSkate. Disponível

em: http://cemporcentoskate.uol.com.br/fiksperto.php?id=5570. Acesso em 20 de janeiro de 2011.

VIDA SOBRE RODAS. Sinopse do filme. Disponível em: http://www.vidasobrerodas.com.br/index2.html. Acesso em 30 de maio de 2011.

WITS BRASIL. "Plano completo do evento". Lótus distribuidora. Disponível em: http://lotusdist.com.br/wild-in-the-streets-sp-200610-mapa-do-evento/. Acesso em: 23 de junho de 2011.

\section{Filmes}

DOGTOWN AND Z-BOYS: ONDE TUDO COMEÇOU. Direção: Stacy Peralta. Roteiro: Stacy Peralta e Craig Stecyk. EUA, Alliance Atlantis, 2001, 87 min.

VIDA SOBRE RODAS. Direção: Daniel Baccaro. Roteiro: Guilherme Keller. Brasil, Walt Disney Pictures, 2010, 110 min.

\section{Sites consultados}

http://espn.estadao.com.br/xgames

http://www.maloofskateboarding.com

http://www.sk8.com.br

http://www.360skate.tv

http://www.orkut.com 
http://www.butanclan.com.br

http://terrivelscrew.blogspot.com/

http://www.cbsk.com.br

http://www.qix.com.br

http://www.youtube.com.br 


\section{Glossário}

50-50: Nome de uma manobra.

Andar de skate: Ato correspondente à prática do skate.

Backside flip: Nome de uma manobra.

Bagulho: Termo polissêmico, muitas vezes utilizado para identificar algum objeto.

Banks: Rampa oval, parecida com uma piscina nos moldes californianos.

Base: Domínio da técnica de certas manobras.

Basudo: Skatista que possui a base de manobras.

Big air: Modalidade praticada em uma mega rampa.

Big two: Escada com apenas dois extensos degraus.

Borda: Quina de equipamentos (como bancos, guias, etc), na qual os skatistas deslizam com o skate.

Borda infinita: Extenso banco situado no Vale do Anhangabaú.

Borda reta: Quina de equipamento, sem nenhum tipo de inclinação.

Bowl: Rampa de skate parecida com uma cápsula grande e funda.

Cabreiro: Expressão indicativa de intensidade.

Caballerial flip: Nome de uma manobra.

Caminhos de rato: Espaço de chão liso entre as pedras portuguesas do Vale do Anhangabaú.

Campeonateiro: Skatista que sempre participa de campeonatos.

Crail air: Nome de uma manobra.

Carrinho: O mesmo que skate.

Causar: Zombar.

Colar: Comparecer.

Combo: Várias manobras feitas em sequência.

Correr: Disputar campeonatos.

Crew: Grupo de amigos.

Curbs: O mesmo que bordas.

Copping block: Bordas de concreto de rampas como banks e bowl.

Double Set: Escadas com duas seções de degraus.

Downhill: Modalidade do skate cujo objetivo é a descida de ladeiras.

Dropar: Descer de alguma rampa. 
Dual Tight: Prática do slalom feita em duplas, onde se valoriza a técnica dos praticantes ao descerem a ladeira por entre cones enfileirados no asfalto.

Espirrar: Quando o skate "espirra", isto é, quando o skatista perde o domínio do mesmo.

Flip: Nome de uma manobra.

For fun: Diversão.

Frontside flip: Nome de uma manobra.

Freestyle: Modalidade do skate praticada no solo, em chão plano sem nenhum obstáculo, cujo estilo de manobras requer sobretudo o equilíbrio do praticante.

Freestylers: Praticantes do freestyle.

Fun box: Obstáculo de uma pista de skate.

Gap: São espaços entre duas partes que os skatistas pulam com suas manobras (ex: barrancos, canteiros, escadas, etc).

Game of skate: Jogo praticado pelos streeteiros, a fim de aperfeiçoarem as técnicas de suas manobras feitas no solo.

Grind: Nome de uma manobra.

Half pipe: Metade de um tubo. Rampa em formato da letra "U".

Hubba: Borda inclinada.

Ibira: Parque do Ibirapuera.

Kickflip: Nome de uma manobra.

Linha: Seqüência de manobras diferentes feitas pelos skatistas.

Local: Indica que o skatista possui um determinado espaço como referência para a prática. Por exemplo: Raphael "Pezão" é local do Parque do Ibirapuera. Logo, o espaço onde ele mais anda de skate é o referido parque. Contudo, isso não quer dizer que deixe de praticar em outros espaços.

Longboard: Skate com dimensões maiores, geralmente utilizado na modalidade downhill.

Longboarders: Aqueles que andam de longboard.

Lugares skatáveis: Espaços que propiciam a prática do skate.

Mandar manobra: Realizar uma manobra.

Manobras bitoladas: Expressão utilizada para se referir aos skatistas que vão à pista somente para treinar um único tipo de manobra.

Manual: Espaço onde são feitas manobras em que se equilibra nas duas rodas dianteiras ou traseiras do skate. 
Mega rampa: Extensa rampa composta por seis partes. Ao todo, mede quase 100 metros de comprimento.

Mini Rampa: Rampa em proporções menores a um half pipe.

Nosegrind: Nome de uma manobra.

Ollie: Nome de uma manobra.

Overall: Skatista que pratica diversos tipos de modalidades.

Palquinho: Obstáculo feito de madeira, parecido com um caixote, com cantoneiras nas quinas.

Pico: Equipamentos urbanos onde se encontram os obstáculos em que os skatistas mandam as manobras.

Pico legalize: Pico onde a prática do skate é liberada.

Pistoleiro: Skatista que anda unicamente em pistas.

Pole jam: Pedaço de ferro torto fixado no chão.

Rachar o bico: Rir com intensidade.

Rampa reta: Obstáculo de uma pista de skate.

Remar: Dar impulso com o skate.

Robozinho: Skatista que quase não erra nenhum tipo de manobra na pista de skate.

Rockslide: Nome de uma manobra.

Rolê: Dar um "rolê" de skate. O mesmo que andar de skate.

Rollers: Praticantes dos patins inline.

Sessão: Andar de skate durante certo período.

Shapes: Prancha de madeira do skate.

Skatepark: Local onde se localiza a pista de skate.

Slalom: Modalidade em que o objetivo é descer ladeiras desviando-se de cones.

Solo: Chão liso propício para mandar manobras.

Street Skate: Modalidade do skate, praticada nas ruas das cidades.

Streeteiro: Praticante da modalidade street skate.

Tailslide: Nome de uma manobra.

Trampar: Trabalhar.

Tesourar: Atrapalhar outro skatista a mandar manobra em algum obstáculo da pista de skate.

Transição: Rampas inclinadas.

Trave: Corrimão reto, sem nenhum tipo de inclinação.

Triple Set: Escadas com três seções de degraus. 
Trombar: Encontrar.

Vale: Vale do Anhangabaú.

Vertical: Modalidade praticada em um half pipe.

Verticaleiro: Praticante da modalidade vertical.

Volta: Apresentação do nível técnico do skatista durante uma competição.

Wallride: Paredes onde os skatistas mandam manobras.

Yeah: Expressão de exaltação do nível técnico de outro skatista. Geralmente é dita quando algum praticante acerta uma manobra. 
ANEXOS 


\section{ANEXO A - Mega rampa: o espetáculo do skate}

Acostumado a receber grandes shows e desfiles de escolas de samba, o Sambódromo do Anhembi tornou-se, durante um final de semana do mês setembro de $2009^{347}$, o reduto de alguns dos melhores skatistas do mundo ${ }^{348}$, que se reuniram para tentar encarar uma rampa com dimensões inusitadas: a mega rampa.

Idealizada pelo skatista norte-americano Danny Way e projetada pelo especialista em construção civil John Tyson, a mega rampa é responsável por conferir uma visibilidade ao skate jamais vista em todo mundo ${ }^{349}$. A sua dimensão é um dos principais atrativos. Ao todo, ela mede quase 100 metros de comprimento. Só para montá-la no sambódromo foram gastos em torno de dez dias, visto que é composta por seis partes principais: drop (rampa de aproximadamente 27 metros de altura, por onde o skatista desce); jump ramp (rampa a partir da qual o skatista realiza o salto); landing (rampa de aterrissagem); rail (corrimão fixado na plataforma do landing, no qual o skatista desliza com o skate); gap (buraco entre a jump ramp e o landing, onde se realiza manobras) e o quarter pipe (rampa inclinada onde o skatista também realiza as manobras ${ }^{350}$ ). Ao descer o drop, a intenção do skatista é, a partir da jump ramp, saltar o gap e aterrissar no landing e, conseqüentemente, realizar uma manobra no quarter pipe. Caso consiga vencer esses obstáculos em uma mesma descida, pode-se dizer que seu objetivo foi atingido ${ }^{351}$.

Somente poucos skatistas são especialistas no big air, modalidade derivada da mega rampa. Além de muita técnica, para realizar os saltos é necessário estar atento a outros fatores. O primeiro de todos é o tipo de skate utilizado, que é bem maior que o de outras modalidades. Em seguida, é essencial estar atento ao clima, pois uma ventania mais intensa ou a direção do vento podem causar sérios tombos. Como prevenção devese utilizar diversos tipos de equipamentos de proteção por todo o corpo. E o principal é ter, além de coragem, muita concentração para enfrentar os obstáculos, pois qualquer vacilo pode ser fatal. Um bom exemplo disso aconteceu justamente com o skatista Danny Way (uma das referências da modalidade) que, em sua passagem pelo Brasil no

\footnotetext{
347 O evento aconteceu entre os dias 26 e 27 de setembro de 2009.

348 Essa afirmação diz respeito aos skatistas capazes de realizar saltos na mega rampa. O critério para esse apontamento é com base nas classificações das recentes competições da modalidade big air, como na Oi Mega Rampa 2008 e nos X Games 2008.

349 Em 2005, Danny Way pulou a Muralha da China, por meio da mega rampa (Disponível em http://revistatrip.uol.com.br/revista/colunas/o-salto-do-skate.html. Acesso em 26 de junho de 2010).

350 As manobras realizadas podem atingir, em relação ao solo, uma altura de até 16 metros.

351 Entretanto, o que diferencia uma descida da outra são as manobras realizadas nas rampas.
} 
evento do ano de 2008, tomou um sério tombo, lesionando-o gravemente na altura do pescoço. Todas essas dificuldades e perigos impostos pelo big air despertam a curiosidade em muitas pessoas, sejam elas praticantes do skate ou não.

Após uma intensa divulgação em sites, rádios, canais de TV, revistas, etc., estava tudo pronto para a realização da Oi Mega Rampa 2009. Promovido por uma empresa de telefonia celular, em parceria com a Prefeitura de São Paulo e com a supervisão técnica da Confederação Brasileira de Skate (CBSk) ${ }^{352}$, esse evento foi "mega" em todos os sentidos: público, cobertura, investimento e organização. Para a realização da edição de 2009, a Secretária de Esportes do Município de São Paulo se comprometeu a investir cerca de R\$500 mil. Além disso, várias marcas dos mais variados segmentos (energéticos, alimentícios, games, informática, confecção, etc.), estiveram envolvidas como patrocinadoras, investindo uma alta quantia pela divulgação de seus produtos.

Os números do evento deixam qualquer investidor impressionado. Ao todo, de acordo com dados da assessoria de imprensa ${ }^{353}$, contabilizou-se o aporte financeiro de R \$5 milhões para sua realização. Só para se ter uma noção, na edição de 2008, o retorno de mídia espontânea, por exemplo, fora de aproximadamente R\$30 milhões. Em 2009, certamente, o retorno fora ainda maior. A intenção dos organizadores é, claramente, econômica: fazer de uma competição entre skatistas um meio de divulgação de produtos que gere lucros. Sérgio Mello, diretor da Brasil 1 Esporte, agência organizadora do evento, define bem a idéia:

Com 100 metros de comprimento, a Oi Mega Rampa é um dos maiores outdoors do mundo. A estrutura é gigantesca e, além de impressionar a todos, facilita também na comercialização dos patrocinadores (Disponível em http://www.oimegarampa.com.br/2009/html/imprensa/. Acesso em $19 \mathrm{de}$ abril de 2010).

Muitos interlocutores desta pesquisa resolveram assistir as competições realizadas na mega rampa; logo, por conta de suas visibilidades, resolvi também acompanhá-las, visto que por meio da prática na modalidade big air, a qual possui inúmeras diferenças

\footnotetext{
352 A espetacularização do skate destaca-se, de uma forma geral, nem tanto pela supervisão técnica e homologação da CBSk, mas sim pela divulgação do evento por algumas mídias, sobretudo, alguns canais de TV aberta. Com efeito, nem sempre os eventos organizados pela CBSk possuem tamanha visibilidade. 353 Disponível em http://www.oimegarampa.com.br/2009/html/imprensa/. Acesso em 20 de maio de 2010.
} 
em relação ao street skate, eu poderia compreender um pouco mais sobre a heterogeneidade no universo do skate.

Para reunir um maior número possível de espectadores no Sambódromo, a organização da Oi Mega Rampa optou por deixar a entrada gratuita. Mas para evitar confusões na entrada, era necessário acessar o site oficial do evento, preencher um cadastro e logo após retirar os ingressos em uma loja credenciada. Ao todo foram disponibilizados, para cada um dos dois dias de evento, 20 mil ingressos. Fiz todos os procedimentos e já com o ingresso em mãos, fui para o Sambódromo do Anhembi. De longe, mesmo antes de entrar no local, era possível ver a mega rampa, que atraía os olhares dos curiosos que passavam pelas redondezas. Na rua havia uma imensa fila repleta, em sua maioria, de jovens. Na portaria diversos seguranças revistavam todos que entravam. Finalmente, após todos os procedimentos, consegui entrar no local.

Antes de chegar à área onde estava a mega rampa era preciso passar por uma espécie de feira, onde produtos eram anunciados pelos patrocinadores ou apoiadores do evento. Denominada de Skate Village, a feira do skate era composta por vários stands que se dispunham em duas fileiras, deixando um espaço central para a circulação do público. Embora todos os stands tivessem quase o mesmo tamanho e formato, havia entre eles, mesmo que indiretamente, uma disputa para atrair a atenção de quem passava pelo local. Valia de tudo: decoração diferenciada; DJs animando o espaço com as mais variadas músicas; garotas distribuindo gratuitamente diversos títulos de revistas e brindes; sorteios de calçados, skates, videogames e outros tipos de produtos. Dependendo da ação promovida, cada um dos espaços ficava cheio em certos momentos. Ao circular pelo local observei que muitos garotos ou garotas, aproveitandose das promoções, carregavam sacolas repletas de brindes.

Mas toda a euforia do Skate Village somente foi contida com o anúncio do locutor, de que a competição estava prestes a se iniciar. Pouco a pouco o local se esvaziava, enquanto as arquibancadas eram ocupadas. Seguindo o fluxo, também fui para as arquibancadas procurar o melhor lugar para me sentar. Sob um sol intenso, as áreas de sombras eram as mais disputadas. Como já foi dito, o público era composto, em sua maioria, por jovens, mas também havia adultos, entre os quais alguns pais com filhos pequenos. Embora a prevalência fosse masculina, havia uma considerável presença feminina. E apesar de o skate ser o carro-chefe das atrações, muitos dos jovens presentes não eram, necessariamente, skatistas. 
Enquanto um seleto grupo de skatistas andava de skate nas rampas, o DJ oficial do campeonato comandava as músicas, que empolgavam os presentes. Os estilos mais tocados eram: punk rock, hardcore, rap e reggae. Havia também uma garota da organização que ficava no meio do público, entrevistando pessoas e sorteando alguns brindes. Pelo telão, que estava à frente da mega rampa, era possível acompanhar tudo. Já o locutor era responsável por "traduzir" a prática, as regras e o nome das manobras da modalidade big air para os leigos. Para os skatistas era tudo mais fácil, pois, de uma forma ou de outra, a maioria acompanhava, mesmo que por vídeos e revistas, a modalidade. Mas quem não andava de skate, ao ouvir o nome de uma manobra, podia ficar completamente perdido, sem saber de nada. O que seria um flip indy no quarter pipe? E um backside ollie 360 na jump ramp? Para familiarizá-las, o locutor desvendava os "mistérios" por trás daqueles giros e rodopios. Desse modo, não bastava só assistir; também era preciso entender, por meio de um "olhar treinado" (Toledo, 2009).

A mega rampa é, de fato, imensa. Olhando de longe, os skatistas ficavam minúsculos diante dela. A cada descida eu sentia - acredito que os demais também - um "frio na barriga", com a expectativa de um provável acerto da manobra ou de um tombo do skatista. Toda a sua extensão era coberta com faixas que faziam referências aos patrocinadores. Aliás, logomarcas e propagandas estavam em todos os lados, por meio de panfletos, adesivos, brindes, camisetas, entre outros materiais promocionais. Enquanto a maioria do público ficava exposta ao sol nas arquibancadas, uma minoria ficava debaixo de tendas montadas (área VIP) em frente às rampas. Havia também alguns famosos (cantores, apresentadores de $\mathrm{TV}$, artistas, etc.) que ficavam nos camarotes, localizados entre as arquibancadas, os melhores e mais aconchegantes espaços para assistir o evento. Além da Rede Globo, que fazia a cobertura completa da competição, havia inúmeros jornalistas de vários canais de comunicação. A mídia especializada em skate também estava presente, mas sem muitos privilégios na cobertura. O skatista e blogueiro Sidney Arakaki, em termos de comparação, postou em seu blog as diferenças entre trabalhar em eventos feitos de "skatista para skatista" e eventos de grande porte, feitos para um público mais amplo:

Pra trabalhar é horrível, mas os campeonatos de skate feitos de skatistas pra skatistas são as melhores festas. Já me diverti muito quando competia e não ligava pra nada. Por mais desorganizado que fosse, sempre tava lá curtindo. E por isso é categoria amadora, por não ser nada profissional e dar mais 
valor no futuro. Os eventos mainstream também são legais, mas na maioria das vezes não tem esse feeling do skate. Quando fizerem um evento como o de ontem com uma organização descente, posso dizer que está próximo da perfeição (Disponível em http://www.skataholic.com.br/2009/08/como-e-

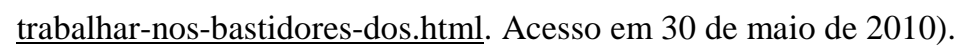

Durante as eliminatórias, havia alguns momentos de pausa para o aquecimento dos skatistas. Nesse instante muitos iam à praça de alimentação, montada no sambódromo; pois, como não podiam entrar com alimentos e bebidas, a solução era fazer compras nas lanchonetes oficiais que comercializavam produtos com preços bem acima da média.

Com o passar do tempo a arquibancada ficava cada vez mais cheia. O locutor, eufórico, vibrava a cada manobra acertada por um skatista. E para deixar mais efervescente aquele momento, conclamava a participação da platéia, para vibrar junto com ele. No skate não há clubismo. Entre os espectadores, provavelmente, não há sentimento de pertença a um único competidor. E se há algum tipo de preferência, ela pode ser mutável e não determinada. Portanto, não vi ninguém que torcesse ou que fosse fã de um único skatista, visto que o que se aprecia são as manobras, isto é, o nível técnico individualmente.

Diversos skatistas mundialmente famosos estavam presentes, entre eles, o australiano Jake Brown e o brasileiro Bob Burnquist. Esses dois nomes são outras referências entre os competidores da modalidade disputada. Mas quem também se destacou foi o jovem garoto Pedro Barros, de apenas 14 anos de idade que, ao lado de skatistas bem mais velhos, conseguiu realizar grandes façanhas nas rampas. Quando um competidor estava prestes a acertar uma manobra, muitos gritavam seu nome em coro, em forma de incentivo. Tal como em outros espetáculos esportivos, aquela coletividade interagia com a competição de uma forma bem particular. No entanto, no domingo de manhã, durante a transmissão da final da competição feita ao vivo feita pela Rede Globo $^{354}$, o público era convocado a gritar ainda mais alto o nome de alguns skatistas e

\footnotetext{
354 Na visão de Sant'Anna (2000, 2), “atualmente, um mesmo campeonato acontece inúmeras vezes e de várias maneiras. A televisão, por exemplo, contribuiu para criar uma noção de espetáculo esportivo até então inexistente: imagens em câmera lenta, em zoom, cenas captando partes específicas do corpo humano em movimento, assim como pontos de vista diferentes filmados graças à presença de câmeras em vários locais de um mesmo espaço geográfico (...). Todos estes recursos confirmam, diariamente, o quanto a evolução técnica não está somente nos materiais e instrumentos utilizados por cada atleta, mas, igualmente, naqueles que o transformam num espetáculo: trata-se, portanto, de uma mudança técnica mas, também, de transformações profundas nas maneiras de criar, avaliar, ver e reproduzir o espetáculo esportivo".
} 
a fazer barulho, para passar uma impressão aos telespectadores de que o evento estava muito animado.

Entre os competidores havia um bom número de skatistas brasileiros, o que despertava ainda mais a atenção do público. Como a mega rampa só é montada no Brasil durante essa competição, os praticantes do big air adotam algumas estratégias para aperfeiçoar o nível técnico. Muitos deles possuem diversos patrocínios que bancam os custos com viagens, salários, plano de saúde, entre outras coisas, que lhes permitem viver profissionalmente da prática do skate. O brasileiro Bob Burnquist, que mora nos Estados Unidos, possui no quintal de sua residência uma mega rampa particular; com isso, os conterrâneos são presenças constantes em sua casa, principalmente antes das competições.

As eliminatórias classificaram alguns skatistas para a grande final. Nesse momento mais esperado, que definiria quem seria o campeão, todos os presentes nas arquibancadas pareciam ter um mesmo foco. A cada descida de algum competidor na rampa, muitos jovens iam ao delírio. Afinal, ver um skatista voando vários metros de altura, correndo risco de vida (qualquer tombo poderia trazer sérias consequiências) e acertando belas manobras em cima de um skate possibilitava uma sensação única para os espectadores daquilo que muitos chamam de esporte "radical". O risco e a incerteza eram o que mais prendiam os olhares, tanto que ninguém queria perder um momento sequer. Por isso, havia uma adequação dos movimentos corporais de cada um dos skatistas àquela situação: era preferível acertar manobras mais fáceis que errar manobras difíceis, tendo em vista que um show com erros não tem a mesma emoção.

Após a efervescente final, ainda houve tempo para a realização do best trick, ou seja, da competição de melhor manobra em alguns dos obstáculos selecionados, como o gap, o quarter e o corrimão (rail). Patrocinadas por algumas marcas, cada uma dessas competições valiam boas quantias em dinheiro. No domingo elas tiveram que seguir à risca o horário, devido à transmissão ao vivo, portanto, não houve atrasos. Sem muita demora, era chegada a hora da premiação. Nesse momento várias pessoas ligadas à organização estiveram presentes para entregar o cheque ao grande vencedor ${ }^{355}$, que por sinal, foi o brasileiro Bob Burnquist. Diante uma multidão de espectadores suponho, de um modo geral, que o mais esperado e exigido por cada um daqueles olhares é uma excelência na performance do skatista. É essencial ter domínio com o skate, seja com os

355 O vencedor recebeu a quantia de US\$16 mil. 
pés ou com as mãos, controlando-o para realizar cada manobra em cima do obstáculo. Os mais constantes são os mais aplaudidos, e esses despertam o maior interesse do público. Para que as técnicas sejam reveladas, é preciso muita prática, e como somente o skatista Bob Burnquist tem uma rampa daquelas proporções para utilizar na hora que lhe convier, era de se esperar que ele também fosse o melhor naquela ocasião.

Vale ressaltar a presença de representantes do poder público (como Walter Feldman, secretário de esportes; Gilberto Kassab, prefeito da cidade e Tiago Lobo, coordenador de esportes radicais), que em diversas vezes proferiram discursos sobre a importância desse tipo de evento para a cidade e também, da intenção em transformar São Paulo em "a capital brasileira dos esportes". Terminada a programação, o Skate Village tornou a ficar cheio, principalmente nos stands, onde alguns dos skatistas competidores davam autógrafos para uma extensa fila de jovens.

A passarela do samba deu lugar a mega rampa. O skate era o esporte da vez, pelo menos naquele final de semana. Todo mundo comentava sobre a tal "rampona" (termo que ouvi de um taxista quando ia embora do evento). Em uma conversa com Rogério "Tilskater", pai de um skatista, ele me dizia que após eventos como este, "as pistas de skate ficam repletas de crianças querendo aprender a andar de skate, motivadas por aquele espetáculo que acabaram de assistir na TV, com skatistas literalmente voando".

Algum tempo depois da realização do evento, tive a oportunidade de entrevistar Tiago Lobo, que salientou a importância deste tipo de iniciativa:

Eu acho que o skate está melhorando, vem se profissionalizando. (...) O evento de grande porte também é importante. É ele que gera conteúdo e interesse nos novos. Se o futebol profissional, se a copa do mundo ou o campeonato brasileiro não passasse na televisão, a molecada não ia jogar futebol, porque eles não iam sonhar em ser um Ronaldinho, um Kaká. É todo um ciclo. É importante o Kaká estar na televisão, o Ronaldinho driblando, dando entrevista, saindo em site de fofoca. Porque é isto que influencia a molecada a sair de casa para jogar bola. Eles vão falar: "meu, eu quero ser igual a ele!”. Eu costumo falar: “o Brasil não é o país do futebol porque aqui o clima é tropical, e por isso que o cara é bom de jogar futebol". Porque quando o cara nasce, dão uma bola para ele, as coisas passam na televisão, ele vai ouvindo no rádio e só vai ver futebol. Então é isto. Não é porque o brasileiro tem uma tendência nata ao futebol. É cultural. Se ele nascesse nos Estados Unidos ele ia ser bom no futebol americano, no beisebol? Nada a ver. Ele foi massificado, enfiaram na cabeça dele que ele 
tinha que ser jogador de futebol. Nos Estados Unidos, que era futebol americano, beisebol, é isto. Então eu acho que é isto. Eu acho que é um trabalho do esporte de ponta, do esporte de alto nível, o investimento é necessário, porque ele que deixa legado. A aulinha de skate na pistinha da esquina é importante. É ela que vai transformar, mas, só vai ter um público de skate freqüentando a aulinha da esquina porque ele viu na Globo o Bob acertando um $x$ na Mega Rampa (Entrevista em 7 de outubro de 2009).

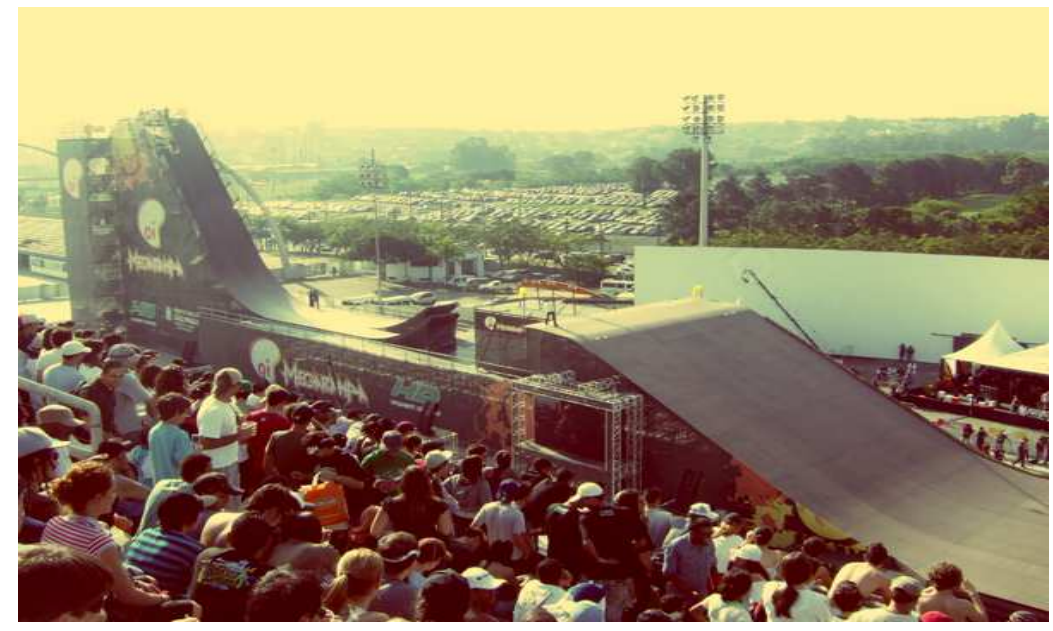

Vista parcial da mega rampa (foto: G. Machado)

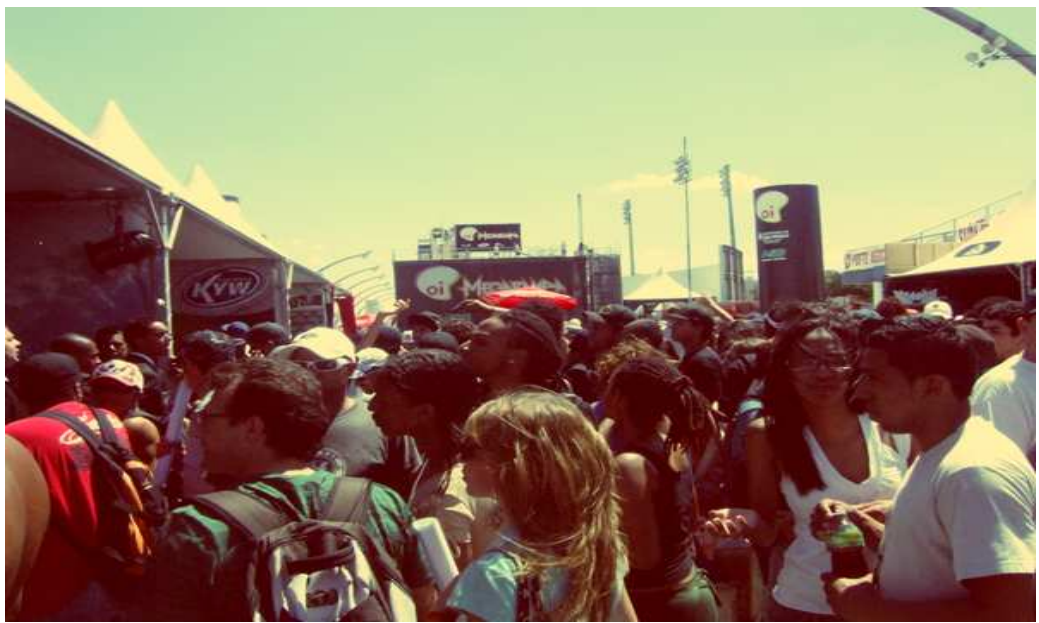

Público no Skate Village (foto: G. Machado) 


\section{ANEXO B - As mulheres e o "carrinho"}

Quando se fala em "skate", logo o associamos ao universo masculino. Mas e as mulheres, como elas realizam e participam dessa prática? ${ }^{356}$ Concomitante a outras atividades, o skate é visto pelo senso comum como sendo perigoso por envolver riscos físicos (como constantes lesões), e também, por exigir demasiado esforço e resistência do praticante, características que comumente não são associadas às mulheres. No contexto histórico em que está fundamentado, a masculinidade sempre foi tida como referência, com os homens representados na condição de sujeitos. Isso pode ser comprovado por meio das representações e dos discursos que foram e estão sendo construídos desigualmente. As revistas especializadas em skate são bons exemplos ${ }^{357}$. No Brasil, entre diversas edições publicadas ao longo dos anos pelos diferentes títulos, em apenas poucas ocasiões as mulheres apareceram na capa, sendo que em algumas delas o que era valorizado não era a prática do skate em si, mas a sensualidade e os atributos físicos. Além do mais, nas duas principais revistas em circulação ${ }^{358}$, são reservados poucos espaços ao skate feminino. Fora desses espaços, que representam pouquíssimas páginas em uma publicação com mais de uma centena, nem sempre há fotos das mulheres em ação.

Contudo, a mobilização feita pelo skate feminino em todo o mundo tem surtido efeitos concretos. A organização dos X Games, um dos maiores e mais importantes eventos do mundo voltado para os esportes "radicais", anunciou em 2008 que a premiação distribuída para homens e mulheres seria a mesma. Aos poucos também surgem publicações, vídeos, eventos e produtos, nas quais o alvo é o skate feminino

Embora não constituísse uma questão em minha pesquisa, a partir do momento em que passei a etnografar o Circuito Sampa Skate - que contava, em cada etapa, com um número significativo de mulheres competidoras - fui levado a fazer alguns questionamentos: como as skatistas se vêem, como são reconhecidas e como se

\footnotetext{
356 Essa questão foi construída a partir da realização do trabalho de campo.

357 Em 1965, a revista norte-americana Life Magazine, estampou em sua capa a foto da skatista Patti McGee, considerada a primeira mulher profissional de skate. Ela ainda teve aparições na revista Skateboarder, mostrando toda a sua técnica, o que era vista como uma exceção nesse universo. Mas isso é um caso a parte e não conferem igualdade as mulheres na história do skate, visto que é apenas um exemplo dentre milhares.

358 As duas principais revistas de skate do Brasil são: Revista Tribo Skate e Revista CemporcentoSkate. Figueira e Goellner $(2009,13)$, ao se remeterem as revistas de skate concluem que as publicações, "em diferentes tempos e espaços evidenciam o quanto o skate no Brasil, é atravessado por relações de poder, promovendo espaços, vivências, oportunidades e sociabilidades distintas para homens e mulheres sendo que para elas, diferente do que para eles, esse parece ser ainda um esporte em construção".
} 
apresentam nesse cenário, onde a masculinidade é tida como referência? Desse modo, tive a oportunidade de observar como as skatistas participantes dos campeonatos se posicionam, compartilham experiências e estabelecem formas de sociabilidade em um ambiente historicamente relacionado às práticas masculinas ${ }^{359}$.

Durante todo tempo em que estive com as skatistas no Circuito Sampa Skate, procurei focalizar as relações que se davam entre elas e suas respectivas performances. Em meio à competição, conversei por um bom tempo com quatro garotas que faziam parte da categoria "feminino II", dentre elas: Mônica Torres, Fernanda Valiati, Jennifer Santos e Mariana Nunes.

Em uma pequena aglomeração de skatistas, sendo todos eles adolescentes, estava Mônica Torres, a única mulher. As roupas que ela usava pareciam com as dos garotos: camisa pólo larga, calça jeans não tão justa, tênis rasgado e boné. Segurando um skate com peças um pouco velhas, essa skatista tentava deixar nítida a influência que recebia por parte dos outros praticantes. Ela era a primeira colocada no ranking da competição até aquele momento, e estava confiante que venceria o circuito. Fernanda Valiati, por sua vez, transitava ora por aglomerações formadas por homens, que eram aqueles seus amigos que moravam perto de sua casa, ora por aglomerações formados por mulheres, que ela conhecia de outros campeonatos. Já Jennifer Santos e Mariana Nunes são amigas bem próximas e sempre andam de skate juntas. Pelo que observei, na maioria do tempo elas ficavam mais entre as garotas que entre os garotos. Entre todas elas, uma coisa em comum: a paixão pelo skate, embora a forma como cada uma o pratique e se posicione nesse cenário seja bem distinta.

Durante as conversas com essas skatistas, as quais se deram em momentos diversos, procurei estabelecer aproximações e distanciamentos entre seus relatos. Um ponto convergente é a forma com que elas entraram no universo do street skate, onde, em cada caso, os homens tiveram alguma participação:

\footnotetext{
Meu irmão ganhou um skate no Natal, e eu ganhei patins. Aí eu queria um skate. O meu irmão me disse para começar a andar de skate. Ele montou um skate com os amigos dele, e falou para me dropar. Eu fui e dropei, gostei e continuei andando. Aí hoje ele trabalha e não pode mais andar (Mônica Torres, entrevista em 30 de maio de 2009).
}

\footnotetext{
${ }^{359}$ Destaco dois artigos importantes sobre a prática do skate pelas mulheres: "Skate e mulheres no Brasil: fragmentos de um esporte em construção" (Figueira e Goellner, 2009); e "Gênero e práticas corporais no site skate para meninas" (Figueira, 2007).
} 
Quando eu tinha uns doze anos, meu irmão andava de skate. Eu gostava de skate, de futebol e tal. E eu queria andar de skate com ele. Nessa época eu não tinha muito apoio do meu pai e da minha mãe. Quando eu fiz uns dezesseis anos, quando eu já podia sair, eu comecei a andar com os amigos (Fernanda Valiati, entrevista em 30 de maio de 2009).

Nas falas dessas garotas, nota-se a forma com que as suas próprias famílias constroem discursos a respeito de quais práticas esportivas elas devem fazer. No primeiro caso, a mãe de Mônica realiza uma distinção e classifica os esportes por meio de gênero, onde a figura do homem está associada ao skate e a da mulher aos patins. Já no segundo, que é um pouco parecido com o anterior, Fernanda relata a falta de apoio dos pais no momento em que passa a praticar o skate. Mas, vemos que tanto para o irmão de Mônica, quanto para o irmão de Fernanda, não havia tantos problemas em ser skatista.

Após a entrada nesse meio, mediante o ingresso em redes de relações, com a vivência de novas experiências e com a apreensão de novos códigos, as mulheres descobrem que o skate, ao contrário do que sempre ouviam, não é uma prática somente para homens. Segundo Jennifer:

Eu comecei a andar de skate porque eu gostava de um menino que andava. No primeiro campeonato em que fui, comecei a ver as meninas andando de skate, comecei a ver o que é o skate de verdade, como não era uma bagunça. Eu fui levar a sério o skate. Engraçado, agora eu ando de skate e ele não anda mais. Eu ando por mim, porque eu gosto, porque eu quero (Entrevista em 30 de maio de 2009).

O começo na trajetória como skatista não é nada fácil, a começar pela própria família, que não vê com bons olhos uma mulher inserida nesse tipo de prática. Conforme falas dessas garotas, os familiares ainda tentam orientar as suas condutas, de modo que optem por atos que "preservem" a feminilidade. Desse modo, as skatistas buscam estratégias para desmistificar a imagem de que praticam um esporte de "macho", e para isso tentam construir discursos de que o skate é uma prática para qualquer um e como qualquer outra. Em muitos dos casos, a família só passa a aceitar, ou, pelo menos a diminuir o preconceito, após alguns resultados práticos da skatista, como, por exemplo, quando ela consegue boas colocações em campeonatos, quando 
aparece em meios de comunicação, quando consegue um patrocínio, etc., pois isso indica uma possibilidade dela vir a construir uma carreira promissora:

No começo eu sofria. Minha avó não aceitava, achava que envolvia muita besteira. Depois de um tempo, fui levando ela nos campeonatos, fui começando a me dar bem. Ela começou a ver que é não só bagunça, que tem um lado bom. Hoje para mim é tranqüilo. Eu saio para campeonatos, viajo, etc. (Jennifer Santos, entrevista em 30 de maio de 2009).

Mas não é só na família que elas sofrem preconceito. Dentro do próprio skate há alguns skatistas que menosprezam ou zombam da presença feminina. No entanto, isso não é algo perceptível à primeira vista, pois caso se pergunte para qualquer um dos homens, a resposta será sempre em tom de aceitação. Em alguns contextos específicos, como nas pistas de skate, as mulheres não são toleradas por alterarem a "ordem" daquilo que o skate masculino constrói:

\footnotetext{
Alguns homens têm preconceito com as mulheres. Tem menino que acha que a gente atrapalha, porque a gente é medrosa na pista. Eles acham que a gente atravessa a pista (Mariana Nunes, entrevista em 30 de maio de 2009).
}

Contrariando a visão de Mariana, Mônica acredita que não há preconceito por parte dos homens, mas, pelo contrário, eles sempre apóiam. Pelo fato de se relacionar com os skatistas, ela ressalta que já rompeu com algumas barreiras impostas, compartilhando dos mesmos espaços que eles sem nenhum problema:

Onde eu ando não tem muita menina, eu sou a única praticante, e eu ando com os caras. Eles me respeitam muito, querem me ver evoluindo sempre mais, e tanto é que muita gente me ajuda (Entrevista em 30 de maio de 2009).

Atualmente, para tentar resolver a disputa pelos espaços, como nas pistas de skate, na qual as skatistas muitas vezes saem em desvantagens, alguns locais estabelecem horários fixos e distintos tanto para homens quanto para mulheres. O Circuito Sampa Skate, como é dividido em categorias, faz com que impere certa igualdade nesse sentido, pois os homens e as mulheres possuem o mesmo tempo para andar na pista. 
Cada garota, depois que começa a praticar o skate, se espelha em outros ou em outras skatistas para que possa aperfeiçoar as técnicas. A influência resulta na forma em que o skate é praticado, seja nos gestos, nos movimentos e até mesmo, na forma de se vestir e se relacionar:

Na verdade, eu fico mais com os meninos. Eu me abro mais com os garotos, porque eu sempre me inspirei muito em menino. Nunca me inspirei muito em menina... Bem pouco nelas. Prefiro ficar mais com os garotos, porque eu tenho uma evolução, assim, é mais fácil de evoluir, ainda mais quando é amigo muito próximo. Mas eu sempre abro, uma hora falo com um, falo com outro (Mônica Torres, entrevista em 30 de maio de 2009).

Mônica acredita que os skatistas são melhores tecnicamente, e que se ela quer evoluir a técnica como praticante do skate é necessário andar com eles, prestando atenção em tudo o que fazem. As skatistas com as quais conversei creditam aos homens características peculiares, muitas vezes vistas por elas como sendo naturais, que fazem com que eles andem de skate com maior facilidade. Para Jennifer, "o homem evolui mais fácil. Eles têm uma facilidade maior com o skate, menos medo". Fernanda salienta ainda que:

Tem a questão fisiológica, que o corpo do homem é mais forte, tem mais potência, tudo isto. E também, tem este fato social. Querendo ou não, o homem anda melhor do que a mulher. Então, o grupinho dos homens está muito mais evoluído que o grupinho das mulheres. Dentro das mulheres, eu acho que está evoluindo bastante (Entrevista em 30 de maio de 2009).

Essas mulheres reproduzem discursos recorrentes ${ }^{360}$, que associam o corpo masculino à força e a agilidade, e como sendo mais apto a realizar alguns tipos de esforços. Para algumas skatistas, o nível técnico é consequiência desses fatores, e por isso, as manobras realizadas por elas não são tão boas quanto à dos homens. Mônica encara a suposta inferioridade técnica feminina como sendo reflexo do medo que as mulheres possuem em praticar o skate, de não se arriscarem com receio de se machucar. Com base nisso ela sugere que:

\footnotetext{
360 Stahlberg $(2009,151-152)$ salienta que "o fato de a sociedade ter como perspectiva dominante a masculina faz com que essa visão seja tida sempre como natural ou neutra mas, na verdade, deve ser compreendida apenas como uma perspectiva".
} 
Para menina andar bem, eu indicaria um esporte que vai dar força a ela. Todo mundo fala que skate é jeito. Para mim não é jeito. Meu skate é força. O meu tamanho, eu sou pequena, mas, até sou forte, porque faço outros esportes. Homem tem a vantagem de ter força. Menina também não tem jeito, não tem coordenação motora, aí complica (Entrevista em 30 de maio de 2009).

No entanto, ela vislumbra que pode buscar uma "facilidade" no aprendizado, assim como os homens:

Eu nunca achei uma dificuldade, entre homem e mulher. Os dois são iguais. Eu me imagino assim, como o homem pode evoluir, eu também posso.

Eu sempre vejo vídeos de skate. Mas, para aprender mesmo, eu vejo pessoas que são da minha base. Por exemplo, o "Xaparral": o jeito que ele movimenta o pé, eu tento movimentar igual, para mandar as manobras. Eu tento imitar as manobras do "Apelão" também ${ }^{361}$ (Entrevista em 30 de maio de 2009).

Mas diferente de Mônica, que é influenciada por aquilo que os homens comumente fazem na prática do skate, Fernanda se espelha nas mulheres skatistas:

Eu me espelho em meninas que evolui bastante. Às vezes eu não me comparo com menino pra andar de skate, pelo fato de eu ser menina, entendeu? Porque eu posso pensar isso e deixar de evoluir. Eu me espelho nas meninas (Entrevista em 30 de maio de 2009).

Essas diferenças revelam ainda as múltiplas corporalidades construídas entre as skatistas, como, por exemplo, entre a Mônica e a Fernanda. Ao observá-las em ação, noto como que elas, enquanto mulheres, portam-se de formas distintas no exercício de uma prática esportiva. Por outro lado, Jennifer e Mariana acusam as skatistas que possuem um nível técnico mais aperfeiçoado, e também, estabelecem distinções até mesmo pelas manobras que são mandadas, que podem ser classificadas como "manobras de homens" e "manobras de mulheres":

Tem manobras que são mais fáceis que as meninas mandam mais. Você sempre vê uma menina mandando noseslide num palco. Quando você vê um

361 "Xaparral” e "Apelão" são apelidos de alguns skatistas amigos de Mônica. 
menino, você estranha. Como eles têm um nível mais alto, é claro que eles têm que andar melhor (...). Eu acho que existem manobras mais de homem. Tem vezes que eu vejo um menino mandando alguma manobra, e eu falo assim: "nossa, que manobra de menina!". Quando você vê uma menina que anda muito, ela anda que nem moleque (Jennifer Santos, entrevista em 30 de maio de 2009).

Menina que anda muito tem mais manobras de meninos. Por exemplo, a Mônica, ela anda só com menino. Para mim, ela anda que nem eles, por isso ela tem este estilo meio molequinho (Mariana Nunes, entrevista em 30 de maio de 2009).

Mariana considera que Mônica possui o estilo de um skatista pelo fato de andar de skate como eles, o que faz com que ela perca as características que são associadas às mulheres. Porém, Mônica justifica com as seguintes palavras: "andar de skate não faz com que eu perca meu lado feminino. Do mesmo jeito que uma menina joga bola, eu tenho direito de andar de skate. É esporte, é para todo mundo".

Para marcar as diferenças em um universo tido como masculino, as mulheres, em dados momentos, constroem discursos valorizando aquilo que chamam de "lado vaidoso". Mariana foi enfática ao me dizer que se acha "mais vaidosa que muita menina que não anda de skate". Já Jennifer, de uma forma geral, ressalta que "todas as meninas andam bem arrumadinhas, fazem as unhas, passam batom". Durante a competição, observei que elas estavam sempre produzidas e que também tentavam chamar a atenção para pequenos detalhes, como as peças do skate ou os equipamentos de proteção que usavam, dos quais muitos eram rosa, que no senso comum é associada a "cor de mulher".

Apresentei apenas breves discursos reproduzidos pelas skatistas em um ambiente (no caso, os campeonatos) onde estão envolvidos tanto homens quanto mulheres. Percebe-se que elas sempre criam distinções ${ }^{362}$, tanto intra quanto intergênero. Enquanto algumas valorizam aspectos como a vaidade ou evocam que são naturalmente mais frágeis e por isso possuem um nível técnico inferior, outras procuram construir uma corporalidade que acreditam estar pautada na força e na potência, e que para isso, não podem ter medo e nem ser frágeis.

362 Compartilho da visão de Stahlberg $(2009,164)$ que nos diz que "a forma, as estratégias, o modo de as mulheres afirmarem sua feminilidade são extremamente reveladores. É importante frisar, finalmente, que não se deve tomar a condição de mulher como uma categoria homogênea, para que não se percam de vista os vários aspectos concernentes aos diferentes tipos de feminilidade e suas diversas demandas". 
Por mais que muitos encarem o corpo como sendo algo dado e com formas fixas, observo que entre as skatistas, por meio dos exemplos vistos anteriormente, as performances são múltiplas, permeadas por vários discursos. Por meio desta análise vejo que há varias formas de ser skatista e de se produzir corpos marcados por gênero. Essa pluralidade no skate feminino aponta para uma gama de feminilidades que são construídas nas relações em que estão inseridas.

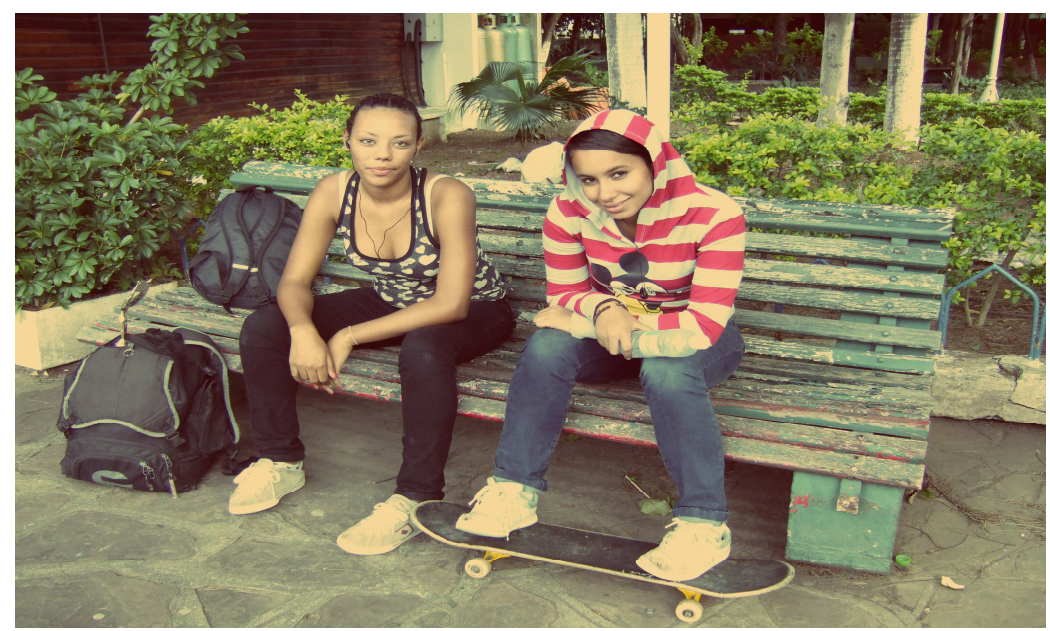

As skatistas Jennifer Santos e Mariana Nunes (foto: G. Machado)

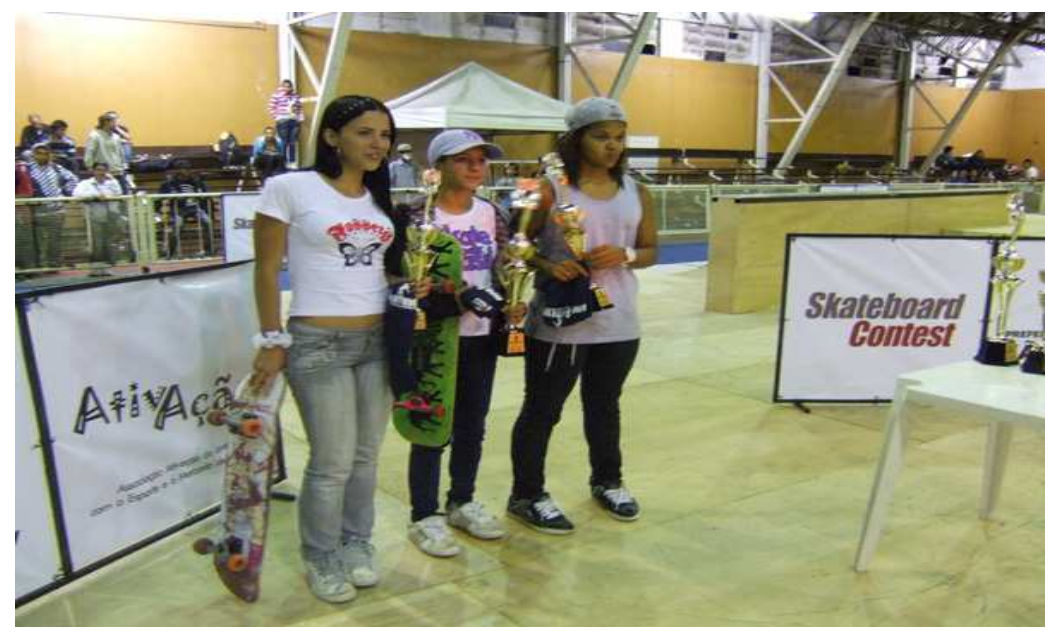

Skatistas participantes do Circuito Sampa Skate (foto: G. Machado) 


\section{ANEXO C - Portfólio para captação de patrocínios}

Alexandre "Nicolau", interlocutor desta pesquisa, tendo em vista a sua procura por patrocínios, elaborou um portfólio pessoal que foi enviado a algumas marcas especializadas em skate. Nele, o skatista faz um breve histórico de sua trajetória, demonstra suas motivações, e apresenta fotos e vídeos de seu nível técnico.

Reproduzo, com a autorização de Alexandre "Nicolau", parte do texto que serviu de base para a formatação de seu portfólio pessoal. Com base nos escritos abaixo é importante atentar-se para a valorização das ruas, a importância das pistas e dos campeonatos, e a necessidade de se fazer imagens por meio de fotos e vídeos.

\section{Portfólio Alexandre "Nicolau"}

Olá, bom dia!

Meu nome é Alexandre, mas no skate sou conhecido como "Nicolau”. Ando de skate há 15 anos, sou amador 1. Tenho grande interesse em fazer parte da equipe (marca tal).

Neste e-mail vou contar um pouco da minha história no skate.

Sou morador da Zona Leste de São Paulo. Comecei andando de skate na rua perto de minha casa, e nunca mais parei. A rua foi amor à primeira vista. Sempre gostei de andar em todos os lugares possíveis e impossíveis da minha região. Então um amigo me levou para conhecer a pista de São Caetano do Sul, berço de vários skatistas que estão aí até hoje!

Um dia eu conheci o centro de São Paulo: Vale do Anhangabaú, Praça da Sé, Praça Roosevelt, Viaduto Santa Ifigênia, Metrô São Bento, entre outros picos. Nesses lugares tive a oportunidade de filmar para um dos únicos vídeos de skate da época, “Chiclé” Vídeo Magazine, e saí nos números 9, 10 e 11.

Mais tarde tive uma participação no vídeo Friends Part 2 - Underground Style também. Este ano 2009, filmei manobras para dois vídeos da BS Crew e no Underground Style. Participei do evento Crail Best Grind, da Crail, que rolou no Brasil inteiro, e fiz parte dos 10 finalistas. Este é link do vídeo do meu f/s ollie 180 fakie nosegrind reverse. Esta mesma manobra está no site da Revista Cemporcento.

Já participei de inúmeros campeonatos no decorrer destes anos de skate, sempre me divertindo com amigos que me incentivaram a participar. Mas fiquei um bom tempo sem participar, por falta de apoio. Em 2008 eu voltei a correr e tive bom resultados. Abaixo cito alguns: 
- Em 2008, de 320 skatistas Amador 1 [no Circuito Sampa Skate], fiquei no ranking em 23;

- No evento TOP 40, de 2008, que foi adiado para o início de 2009, minha colocação foi $26^{\circ}$;

- Em 2009, de 201 skatistas amador 1, fiquei no ranking em $6^{\circ}$;

- No evento TOP 40, que aconteceu no fim de 2009, minha colocação foi $8^{\circ}$ lugar.

Sou formado em Gestão Financeira, pela Universidade Cidade de São Paulo (UNICID). E também participo do Circuito Universitário, em São Paulo. Em 2009 eu participei de uma etapa, que foi no Vale do Anhangabaú, no dia da Virada Esportiva. Fiquei colocado em $9^{\circ}$ lugar. E em $21^{\circ}$ no ranking geral.

Este ano 2010 eu tenho pretensão de fazer mais vídeos, fotos, participar de eventos e continuar correndo campeonatos. Por isso, estou em busca de uma oportunidade na equipe de (marca tal).

Fico no aguardo de um possível retorno. Obrigado.

\section{Nicolau}




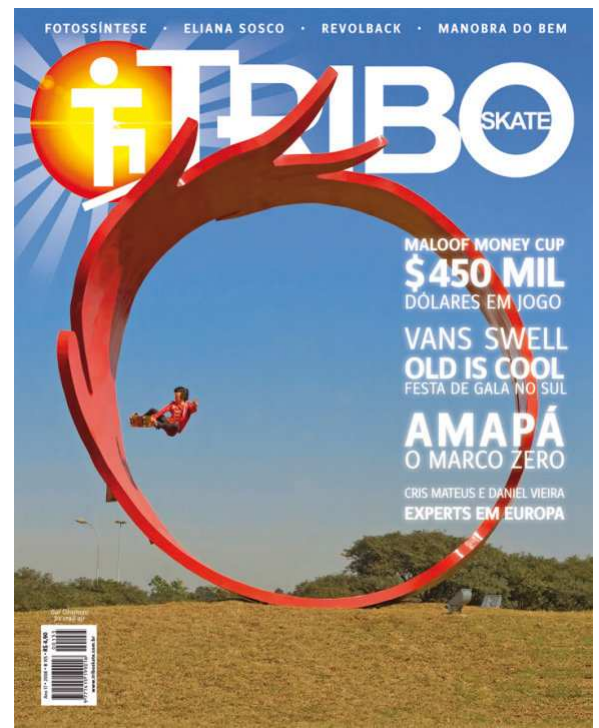

O skatista Guilherme Okamoto realiza uma manobra em um pico cuja prática é proibida (escultura na área do aeroporto de Guarulhos - SP). Revista Tribo Skate, edição 155, setembro de 2008. Foto: Marcelo "Mug".

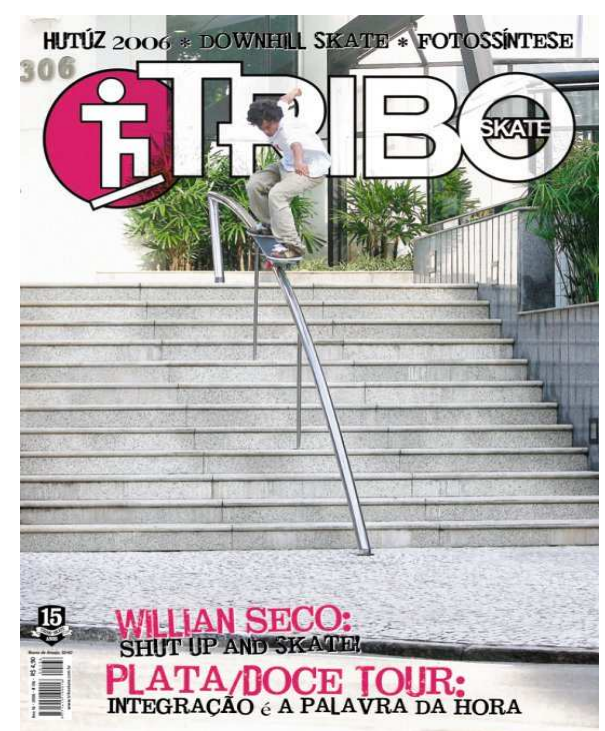

O fotógrafo Shin Shikuma, aproveitando-se da desatenção dos seguranças de um prédio por conta dos jogos da Copa do Mundo FIFA, em 2006, conseguiu fazer a foto do skatista Bruno Araújo em um corrimão localizado em um espaço cujas normas são privadas. Revista Tribo Skate, edição 136, fevereiro de 2007. Foto: Shin Shikuma. 


\section{ANEXO E - Documentos referentes ao projeto de lei 116/2009}

\section{PROJETO DE LEI 01-0116/2009 do Vereador Adolfo Quintas (PSDB) ${ }^{363}$}

“Acrescenta-se o inciso XXVI ao Artigo $1^{\circ}$ da Lei 10.328 de 03 de junho de 1987, que dispõe sobre as infrações administrativas que especifica, estabelece as respectivas penalidades, e dá outras providências.

\section{A CÂMARA MUNICIPAL DE SÃO PAULO decreta:}

Art. $1^{\circ}$ - Acrescenta-se o inciso XXVI ao Artigo $1^{\circ}$ da Lei 10.328 de 03 de junho de 1987, com a seguinte redação:

Art. $1^{\circ}$ - Fica expressamente proibido no território do município de São Paulo:

Inc. XXVI - utilizar "skate" nas calçadas, exceto área reservada para este fim, na forma da regulamentação a ser expedido pelo Executivo.

Penalidade: Multa de 01 (uma) U.F.M. - Unidade de Valor Fiscal do Município dobrada, na reincidência".

Art. $2^{\circ}$ - As despesas decorrentes da execução desta Lei, correrão por conta das dotações orçamentárias próprias, suplementadas, se necessário.

Art. $3^{\circ}$ - Esta lei será regulamentada no prazo de 120 dias, contados da sua publicação.

Art. $4^{\circ}$ - Esta lei entra em vigor na data de sua publicação, revogadas todas as disposições em contrário.

Sala das Sessões, 05 de março de 2009. Às Comissões competentes”.

363 Disponível em: http://camaramunicipalsp.qaplaweb.com.br/iah/fulltext/projeto/PL0116-2009.pdf. Acesso em 22 de junho de 2011. 


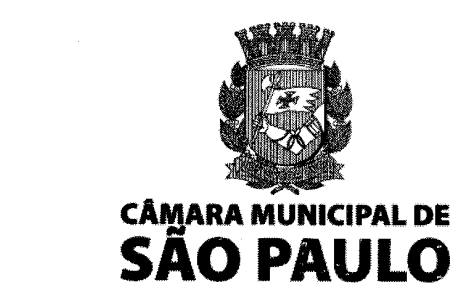

\title{
Gabinete Vereador Adolfo Quintas GV $34^{\circ}-\mathrm{PSDB}$
}

JUSTIFICATIVA

$$
\text { PL116/09 }
$$

\begin{abstract}
A presente propositura tem como objetivo central proibir a utilização do skate nas calçadas no município de são Paulo.

A cidade de São Paulo, possui como destaque sua diversidade cultural, gastronômica, social, esportiva, etc... Desta forma, obrigando seus moradores, uma superação diária, o exercício da cidadania plena, ou seja, o usufruto dos seus direitos, mas também o cumprimento dos seus deveres. Ocorre que nem todos os direitos ou deveres estão dispostos em norma legal. Devendo aos seus habitantes se socorrerem dos hábitos e costumes na boa convivência social, desta megalópole que se chama São Paulo com 10.886.518 habitantes segundo dados de 2007 do Instituto Brasileiro de Geografia e Estatística - IBGE.

Desta forma, os moradores vem enfrentando um grave dilema como, por exemplo, em reportagem veiculada sob o titulo "Av. Paulista vira pista de Skate" em 11 de julho de 2008 no Jornal da Tarde relata:
\end{abstract}

\section{Skatistas têm usado as novas calçadas para treinar. Prefeitura diz que não há lei que os impeça}

As calçadas da Avenida Paulista foram reformadas, receberam pavimento novo, liso e de concreto, as novas calçadas tem atraído cada vez mais skatista em busca de manobras radicais, lazer e treinamento para campeonatos do esporte.

Desde o inicio das obras, em julho de 2007, é comum vê-los desviando de pedestres. Atualmente circulam cerca de 1,7 milhão de pessoas diariamente, destes com suas diversidades, algumas residem ou trabalham outras buscam os serviços médicos da região. Não poderíamos deixar de citar que a região da Avenida Paulista possui a maior concentração de equipamentos hospitalares e ambulatoriais em nosso município. Existem relatos de pedestres que sentem-se ameaçados pelo uso do skate nas calçadas.

Palácio Anchieta - Viaduto Jacareí, 100 - 6º Andar - Sala 615 - Tel: 3396-4265 adolfocuintas@camara.so.qov.br 


\section{数 \\ and \\ SÂO PAULO}

\section{Gabinete Vereador Adolfo Quintas GV $34^{\circ}$ - PSDB}

Outro detalhe a ser analisado é que segundo a Subprefeitura da Sé, o custo da reforma fora estimado em R\$ 8,1 milhões.

Isto posto, a municipalidade não pode se omitir com relação à possibilidade de danificação do equipamento publico, já que as calçadas, jardineiras e lixeiras são especificadas como tais. E desta forma, é principio inerente a Administração Publica o dever de zelar pelo patrimônio publico.

Não obstante se entenda o caráter necessário da pratica do esporte em tela, ou seja, o skate, temos que salientar que além dos fatos aqui narrados, o Brasil hoje é considerado um país formado na sua maioria por idosos, notoriamente na cidade de São Paulo, onde este numero supera as demais cidades de nosso país. Ora o transito de pessoas idosas cumulado com a pratica do skate tem levado riscos a toda classe etária, porem os idosos é quem sofrem mais, já que caso ocorra um acidente sua recuperação levará mais tempo, isto sem mencionar os casos em que as seqüelas são irrecuperáveis, gerando, destarte, despesas ao município e a sua coletividade imensuráveis.

Estes são os motivos pelos quais solicito aos Nobres Vereadores desta Casa de Leis, a aprovação da presente propositura. 


\section{ANEXO F - "Essas ruas são nossas!"}

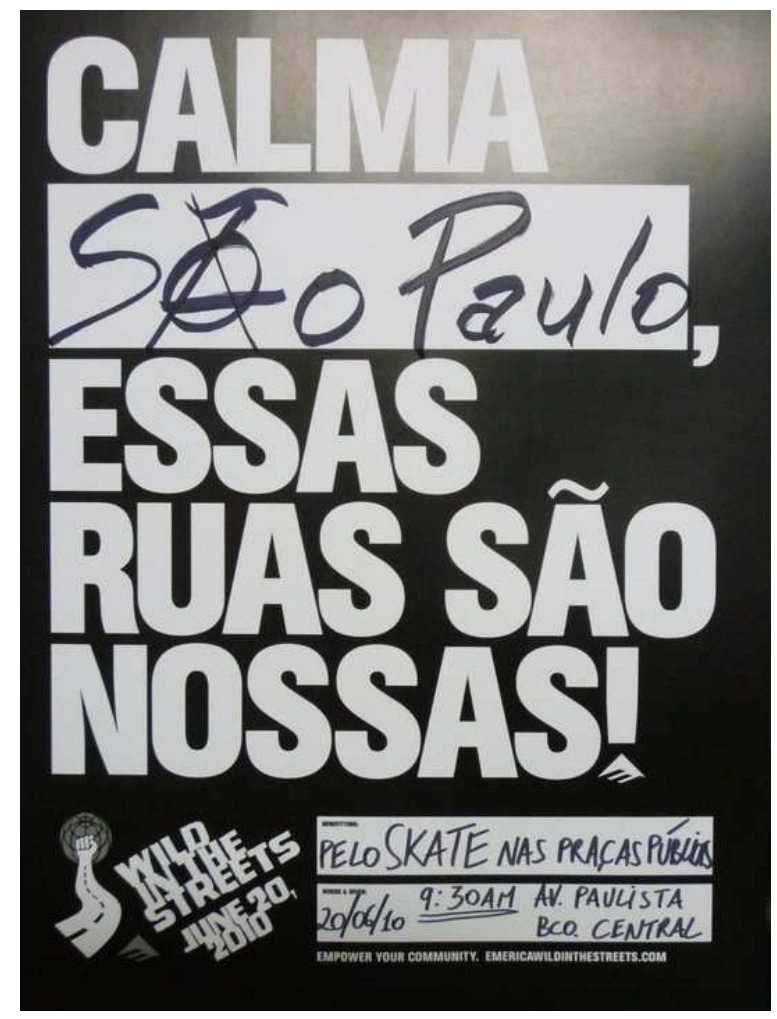

(Imagem: Divulgação Lótus Dist. Disponível em: http://lotusdist.com.br/)

Em 2010 e 2011 aconteceu na cidade de São Paulo o "Wild in the Streets", evento promovido por uma marca de tênis em comemoração ao Dia Mundial do Skate, realizado no dia 21 de junho. Milhares de skatistas saíram pelas ruas em protesto contra a repressão da prática do skate em espaços públicos. Mais informações sobre o "Wild in the Streets" em: http://lotusdist.com.br/wild-in-the-streets-sp-200610-mapa-do-evento/. 